Historic, Archive Document

Do not assume content reflects current scientific knowledge, policies, or practices. 



\section{Archias' Evergreen Lawn Grass Seed}

This is a mixture of celebrated Kentucky Blue Grass and other soft bladed grasses that will withstand the heat and dry weather of our summers and our most severe winters, and insure permanent evergreen lawn. Archias' Evergreen Lawn Grass seed is as pure and reliable as can be found anywhere. We highly recom-
mend this mixture for general purposes.

Price of Archias' Evergreen Lawn Grass Seed-1 lb. 40c; 10 lbs., $\$ 3.50$; 25 lbs. $\$ 7.50$. prepaid,

\section{Archias' "Sure" Brand} Kentucky Blue Grass

Blue Grass is a very valuable lawn grass. Our stock is direct from Kentucky and should not be compared with the cheap Western wild blue grass seeds offered by some houses. Sow two bushels per acre for lawn. Extra fancy, per $11.40 \mathrm{c}$. Nost

prepaid, pk., \$1.00; $1 / 2$ bu., $\$ 1.90$; bu. (14 lbs.), $\$ 3.25 ;$ bu. or over, $\$ 3.60$ per bu. Sacked free

Archias' Shady Nook " Lawn Grass Mixture

A mixture of grasses that will thrive in a shady situation, under trees or close to walls where there is little sun. Lb., 40c; 10 lbs., $\$ 3.50 ; 25$ lbs., $\$ 7.50$.

\section{TO PRODUCE A GOOD LAWN}

Archias’ Terrace Sod Lawn Grass Seed

Best mixture for sowing on terraces, railroad embankments and side hills, preventing heavy rains from washing. Will withstand drouth and produce a rich, velvety green turf throughout the season. Lb., 40c; 10 lbs., $\$ 3.50$ 25 lbs., \$7.50.

Plow or dig up the surface thoroughly to a Archias' Sure Lawn Fertilizer, the latter being at all times preferable, as it is more durable in its effect and free from weed seeds, which are always contained in more or less quantities in stable manure.

The soil should be well pulverized before sowing, and the lawn kept free from weeds the first season. The quantity of seed required is one pound to every 300 square feet.

\section{Subjects Illustrated on Cover}

\section{ARCHIAS' DELICIOUS APPLE}

The most wonderful apple of the day. See page 70 .

\section{ARCHIAS' MISSOURI PRIDE PEACH}

Far superior to Elberta in both quality and productiveness. You will make no mistake by planting Archias' Missouri Pride. See page 70

\section{ARCHIAS' MAMMOTH CONCORD GRAPES}

Most prolific, most attractive, most luscious and an a!l round profitable variety. Should be in every garden. See page 71 .

\section{ARCHIAS' PROGRESSIVE EVERBEARING STRAWBERRIES}

Too well known for comment. Strawberries all year round of excellent quality. See page 72 .

EVERBLOOMING ROSE-KAISERIN A. VICTORIA

The most perfect white rose that is hardy and a free bloomer. See page 63.

\section{ARCHIAS' HARDY PERENNIALS}

Nothing that will give you more satisfaction than a good assortment of hardy perennials that bloom constantly each season and improve with age. See page 66 .

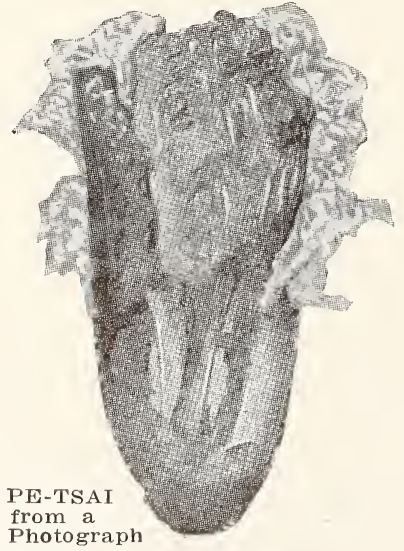

\section{Archias' Chinese or "Celery" Cabbage}

We offer the true Pe-Tsai or Chinese Cabbage, which has been known and cultivated in China for many years. Pe-Tsai produces beautiful crisp, celery heads that blanch easily and that resemble a giant Cos- Lettuce. As a salad it rivals the finest lettuce, while cooked like cabbage or spinach it makes a delightful "greens."

Early sowing is not recommended, as during hot weather it has a tendency to run to seed without heading. Sow seed, in any good soil, the first of August, making rows 24 to 36 inches apart and thinning to fifteen inches apart in the row. Pe-Tsai will not stand frost, so that heads intended for winter use should be stored in a cool frost-proof celler. Pkt., 10c; oz., 30c; 1/4 1b., 85c; lb., $\$ 3.00$, postpaid. 
Terms Cash with all orders. Positively no goods sent C. $\mathbf{0}$. D.. All claims for errors must be made on receipt of goods

\section{ARCHIAS' SEED STORE CORPORATION}

106-108 East Main Street,

SEDALIA, MO.

Send the following as directed on blank lines below with the understanding that should I discover on receipt of goods that any mistake has been made, I shall advise you promptly, so that you may replace the seeds, plants, bulbs or trees or refund the price, at your option, as per your printed Warranty in catalog, the terms of which I accept.

Date. $191 \ldots \ldots$ Please Do Not Write in This Space

Your Name

Postoffice

County

State.

Name Your Freight Station.

How to be Sent, Freight, Express, Mail.

Amount Enclosed, \$.

State whether P. O. Order, Express Money Order, Draft, Postage Stamps or Cash.

Number.

Rec'd

Am't Enc.

Filled by

Date For'd

For'd by

Very Important-No difference how often you have written us, always give your Full Address and write your Name, Postoffice, County and State very plainly; by so doing you will save much trouble and avoid the possibility of delay and mistake in filling your orders.

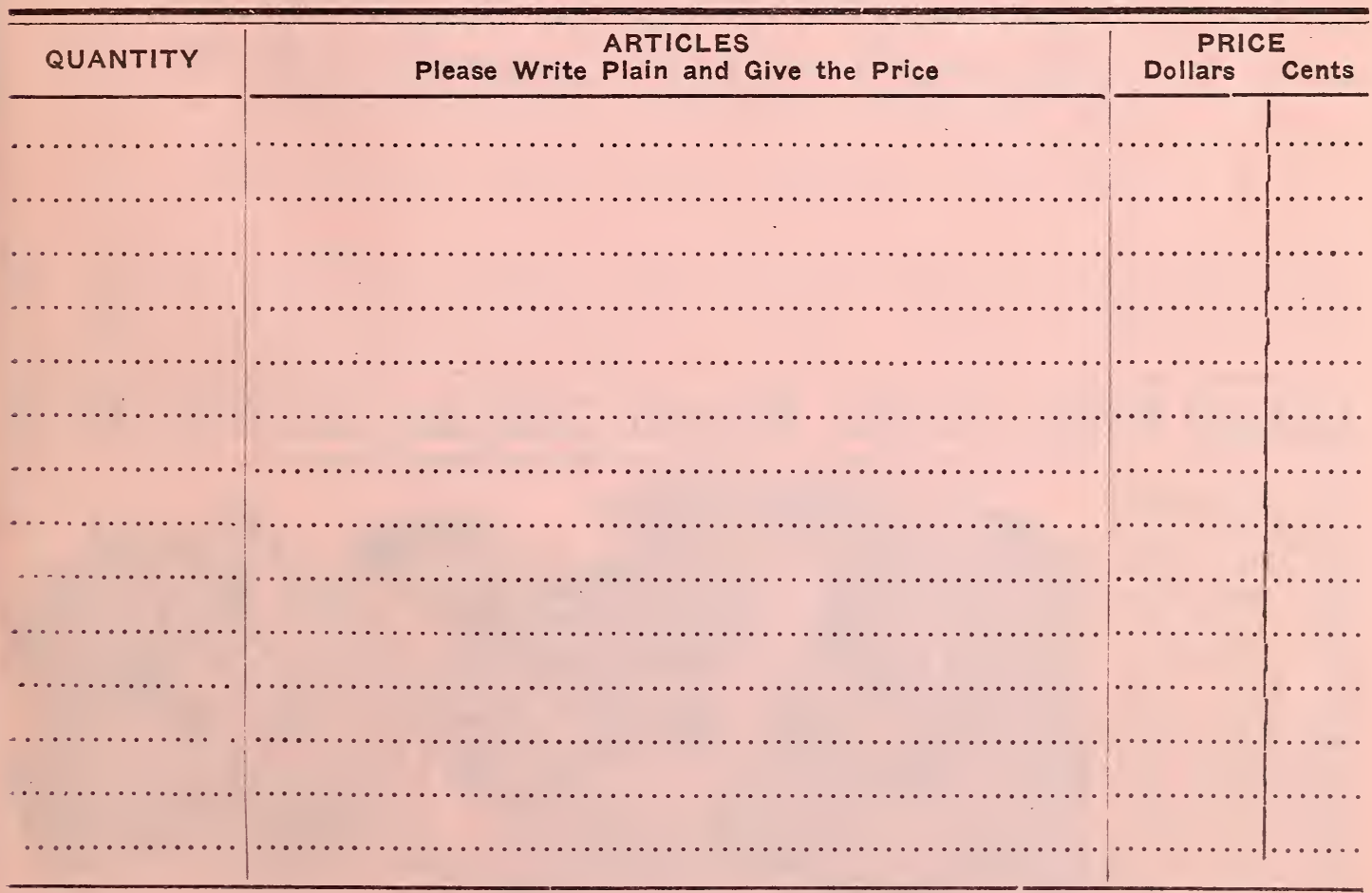

NOTICE-We pay postage on Garden Seeds by Paper, Ounce or Pound. If Peas, Beans or Corn are ordered, add $8 \mathrm{c}$ per quart and $5 \mathrm{c}$ per pint to Catalog price for postage. 
ORDER SHEET-Continued

\begin{tabular}{|c|c|c|c|}
\hline \multirow[t]{2}{*}{ QUANTITY } & NAME AND SIZE OF ARTICLE & \multicolumn{2}{|c|}{$\begin{array}{l}\text { PRICE } \\
\text { lars C }\end{array}$} \\
\hline & Amount brought forward & & \\
\hline$\cdots \ldots \ldots \ldots \ldots$ & 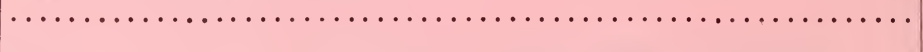 & $\cdots \cdots \cdots \cdots$ & $\cdots \cdots$ \\
\hline$\cdots \cdots \cdots \cdots \cdots$ & $\cdots \ldots \ldots \ldots \ldots \ldots$ & $\cdots \cdots \cdots \cdots$ & $\ldots \cdots$ \\
\hline$\cdots \ldots \ldots \ldots \ldots$ & 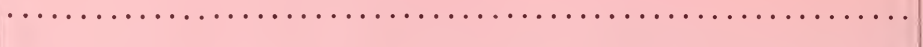 & $\cdots \cdots \cdots \cdots$ & $\cdots \cdots$ \\
\hline$\ldots \ldots \ldots \ldots \ldots$ & 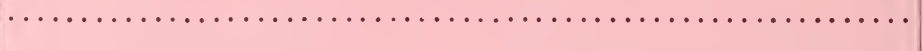 & $\cdots \ldots \ldots \ldots$ & $\cdots \cdots$ \\
\hline$\ldots \ldots \ldots \ldots \ldots \ldots$ & 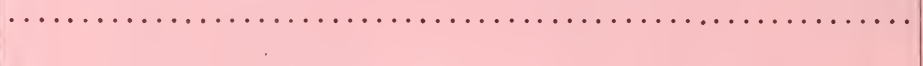 & $\ldots \ldots \ldots \ldots$ & $\cdots \cdots$ \\
\hline$\ldots \ldots \ldots \ldots \ldots$ & 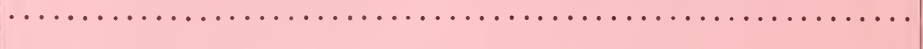 & $\ldots \ldots \ldots \ldots$ & $\cdots \cdots$ \\
\hline$\cdots \ldots \ldots \ldots \ldots$ & $\ldots \ldots \ldots \ldots \ldots \ldots \ldots \ldots \ldots \ldots \ldots \ldots \ldots \ldots \ldots \ldots \ldots \ldots \ldots \ldots \ldots \ldots \ldots \ldots$ & $\cdots$ & . \\
\hline$\cdots \cdots \cdots \cdots \cdots$ & 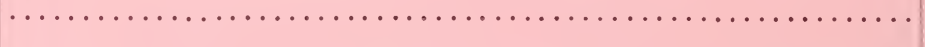 & $\cdots \cdots \cdots$ & $\cdots$ \\
\hline$\cdots \cdots \cdots \cdots \cdots$ & 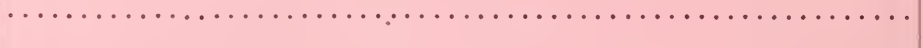 & $\ldots \ldots$ & $\cdots \cdots$ \\
\hline$\cdots \ldots \ldots \ldots \ldots \cdots$ & 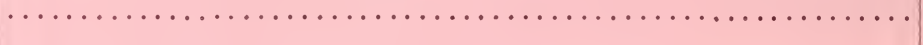 & $\cdots \cdots \cdots$ & $\cdots \cdots$ \\
\hline$\cdots \ldots \ldots \ldots \ldots$ & $\ldots \ldots \ldots \ldots \ldots \ldots \ldots \ldots \ldots \ldots \ldots \ldots \ldots \ldots \ldots \ldots \ldots \ldots \ldots \ldots \ldots$ & $\cdots$ & $\ldots$ \\
\hline$\ldots \ldots \ldots \ldots \ldots$ & 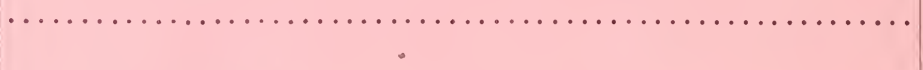 & $\ldots \ldots \ldots \ldots$ & $\cdots \cdots$ \\
\hline$\cdots \cdots \cdots \cdots \cdots$ & 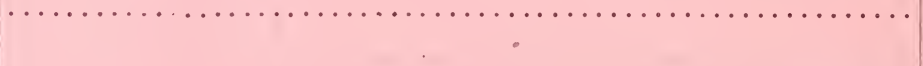 & $\cdots \cdots \cdots \cdots$ & $\cdots \cdots$ \\
\hline$\cdots \cdots \cdots \cdots \cdots$ & $\ldots \ldots \ldots \ldots \ldots \ldots \ldots \ldots \ldots \ldots \ldots \ldots \ldots \ldots \ldots \ldots \ldots \ldots \ldots \ldots \ldots$ & $\ldots \ldots \ldots$ & $\ldots \ldots$ \\
\hline$\cdots \ldots \ldots \ldots \ldots$ & $\ldots \ldots \ldots \ldots \ldots \ldots \ldots \ldots \ldots \ldots \ldots \ldots \ldots \ldots \ldots \ldots \ldots \ldots \ldots \ldots \ldots$ & $\cdots \cdots \cdots \cdots$ & $\cdots \cdots$ \\
\hline$\cdots \ldots \ldots \ldots \ldots$ & 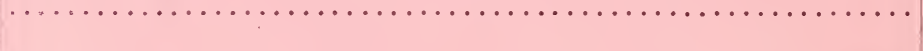 & $\cdots \cdots \cdots$ & $\cdots \cdots$ \\
\hline$\cdots \cdots \cdots \cdots \cdots$ & $\ldots \ldots \ldots \ldots \ldots \ldots \ldots \ldots \ldots \ldots \ldots \ldots \ldots \ldots \ldots \ldots \ldots \ldots \ldots \ldots \ldots \ldots$ & $\cdots \ldots \ldots$ & $\cdots \cdots$ \\
\hline$\cdots \ldots \ldots \ldots \ldots$ & 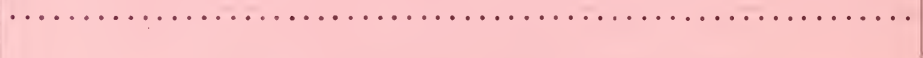 & $\ldots \ldots \ldots \ldots$ & $\ldots \ldots$ \\
\hline$\ldots \ldots \ldots \ldots \ldots$ & 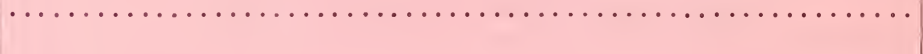 & $\ldots \ldots \ldots \ldots$ & $\ldots \ldots$ \\
\hline$\cdots \cdots \cdots \cdots \cdots \cdots$ & 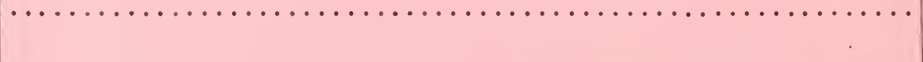 & $\cdots \ldots \ldots \ldots$ & $\cdots$ \\
\hline$\cdots \ldots \ldots \ldots \ldots$ & 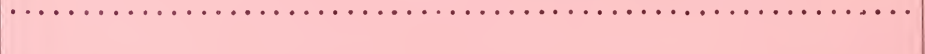 & $\cdots \ldots \ldots$ & $\ldots \ldots$ \\
\hline$\ldots \ldots \ldots \ldots \ldots$ & 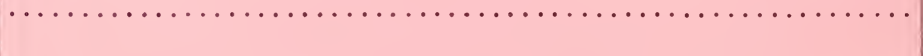 & $\cdots \ldots \ldots \ldots$ & $\cdots \cdots$ \\
\hline$\ldots \ldots \ldots \ldots \ldots$ & $\ldots \ldots \ldots \ldots \ldots \ldots \ldots \ldots \ldots \ldots \ldots \ldots \ldots \ldots \ldots \ldots \ldots \ldots \ldots \ldots \ldots \ldots$ & $\ldots \ldots \ldots \ldots$ & $\ldots \ldots$ \\
\hline$\cdots$ & $\ldots \ldots \ldots \ldots$ & & \\
\hline
\end{tabular}

\section{Archias' Great "Jumbo" Bargain Collection \$2.25 Worth of $\$$ seeds For Only $\$ 1.25$} A Grand Collection of Choicest Vogetables and Flegant Flowirs

One large package, each of Beets, Early Cabbage, Late Cabbage, Carrots, Celery, C u c u m ber, Endivo, Kohl Rabi, Curled Lettuce, Head Lettuce, Leek, Musta $\mathbf{r}$, Watermelon, Musk Melon, Red Onion, Yellow Onion, Okra, Parsnip, Pepper, P u m p i n, Parsley, Early Radish. Long Radish, Winter Radish, Rutabaga, Sage, spinach, Warly Squash. Spinach, warly Squash, Winter Squash, Turnip, Tomato, 5 large packets Flower Seeds-36 large packets in all. Sent, postpaid, ONI
\$1.25. Order early.

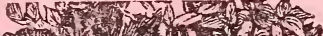

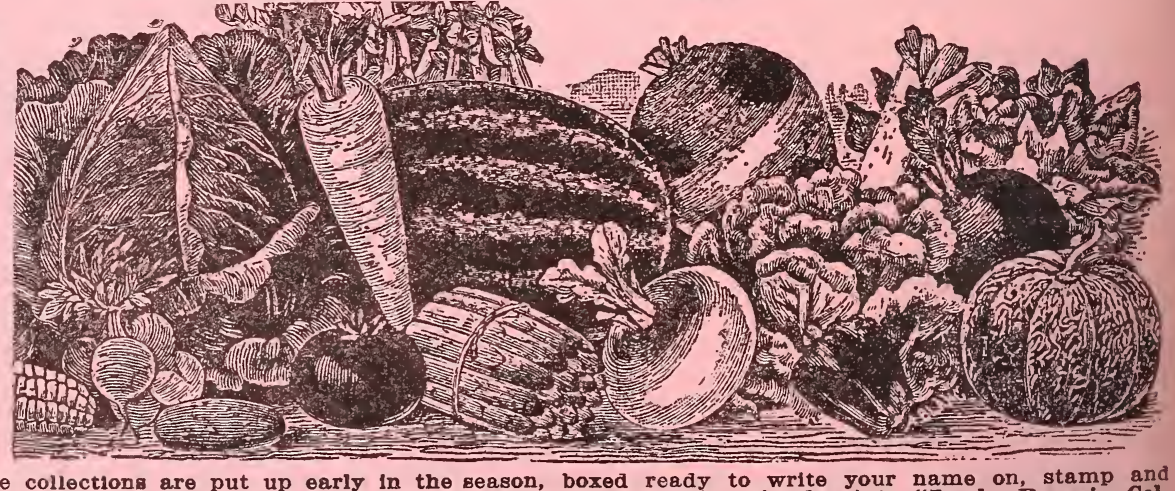
Thousands of these collections are put up early in the season, boxed ready to write your name on, stamp and lection." 


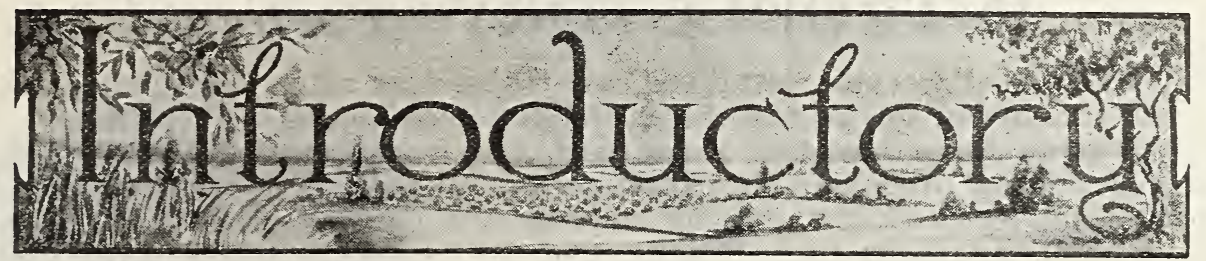

\section{SEED WARRANTY}

Tost of the failures with seeds are entirely beyond our control and they render it impossib'e for us to guarantee success, and therefore we want it plainly understood that while we exercise great care to have all seeds, plants and bulbs, pure and reliable, and also true to name, we do not give any warranty, express or implied, as to description, quality, productiveness or any other matter, of any seeds, bulbs or plants which we send out, and we will not be in any way responsib.e for the crop. No officer, agent or employe of this company is authorized to make any warranty whatsoever. If the purchaser does not accept the seeds, bulbs or plants on these conditions. notify us at once and we will give instructions for disposition of same, and the money that has been paid for same to us will be promptly refunded. It is to our interest, however, to have everything of the highest quality ohtainable, and we would not furnish seeds of doubtful quality for several times the price that we receive from them, as it would injure us more than it would the purchaser. However, we have so much confidence in our seeds that we herehy agree to refill any order for vegetable or flower seeds free of charge should they prove otherwise than as we represent them. We know of no responsible seed firm which guarantees seeds any further than this. WN Compare with other catalogues and you will find that we are right.

L. H. Archias, Pres.

L. A. Kipping, Vice-Pres. and Mgr.

L. Archias, Sec'y

\section{Archias' Seed Store Corp.}

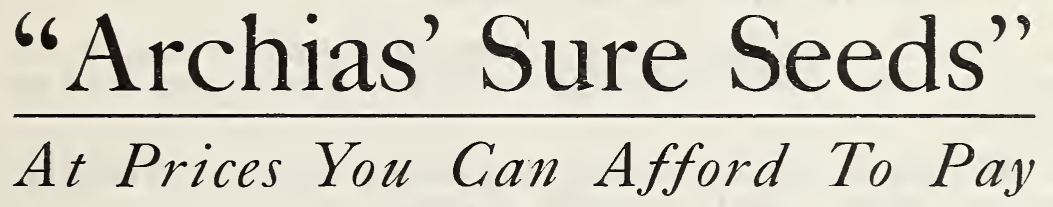

CUCCESSFUL Gardeners, Farmers and Flower Lovers, all over this country have $\checkmark$ planted "Archias' Sure Seeds." I have made the selling by -mail of seeds, plants, bulbs, nursery stock and supplies my life work. Starting in business in 1884, made me one of the first to sell by mail.

"Archias" Sure Seeds" are low in price, but if they didn't make good I never would have been able to build up my present big business. So, don't confuse my seeds with the cheap seeds offered by so many grocerymen, hardware dealers and irresponsible seed houses that sell at prices below the bare cost of production of first class seeds.

My "Sure Seeds" are strong in vitality. They are procured from properly selected, cultivated and rogued fields and are good as grown. They are known to almost everybody that plants seeds. Archias' Red Seal "Sure Seed" trademark is your guarantee of quality. "Archias" Sure Seeds are tested and tried for purity and germination, and are carefully selected.

We have one of the best and most complete systems of seed testing anywhere, and large trial grounds. I pay particular attention to seeds suitable for planting in Central and Southern States.

Wishing you a successful season and a bountiful harvest, I am, 


\section{INTRODUCTORY-Continued}

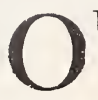

UR Mail Order Service, improved, as it has, year after year, places you within a few hours of one of the oldest and best seed houses in the country. Sedalia, our home, is in the heart of the best and richest agricultural country. Our soils are capable of producing the finest seeds. Our shipping facilities are excellent. We enjoy comparatively low freight, express and parcel post rates. Railroads run in six different directions from Sedalia, and we have over thirty mails daily. Our offices and warehouse are equipped for handling many orders quickly. We employ trained help.

\section{OUR GREENHOUSES AND NURSERY.}

We own the largest and best equipped system of up-to-date greenhouses in Central Missouri, where our customers are supplied with the finest plants, sut flowers, floral designs and nursery stock, fresh and in fine condition.

\section{OUR LIBERAL CASH DISCOUNTS.}

Free Seeds or Discounts for Large Oders.

\section{BULK SEED DISCOUNT.}

On orders amounting to $\$ 5.00$, deduct 10 per cent.

On orders amounting to $\$ 10.00$, deduct 12 per cent.

On orders amounting to $\$ 15.00$, deduct 15 per cent.

Providing you use the prices given in this book, and do not include any Field Seeds, Grass Seeds, Potatoes, Onion Sets, Poultry Supplies, etc., on which we only give lowest net prices at time catalog is issued.

\section{PACKET AND OUNCE SEED DISCOUNT.}

For $25 \mathrm{c}$ we send $30 \mathrm{c}$ worth of seeds, packet or ounce.

For $50 \mathrm{c}$ we send $65 \mathrm{c}$ worth of seeds, packet or ounce.

For $\$ 1.00$ we send $\$ 1.30$ worth of seeds, packet or ounce.

In taking advantage of our packet and ounce discount no larger quantities than packets or ounces of-any kind can be included.

FREE SEEDS-In addition to the above discounts we make a rule of throwing in extra packets where liberal orders are sent in. Try us once and see if we don't treat you right.

SEND MONEY by Express, Draft, Registered Letter or Postoffice Money Order. We accept clean $1 c$ and $2 \mathrm{c}$ stamps same as cash.

WE SELL half pound or over at pound rates, half bushel at bushel rates.

WE GUARANTEE SHIPMENTS of Seeds, Bulbs, Plants, Implements, etc., shall reach the purchaser in good condition when sent by mail or express.

CHANGE OF ADDRESS-If you have changed, or intend to change your address, please let us know, so that we may change it on our books. If you have rural mail delivery, be sure to add the number of your route.

WE PREPAY POSTAGE ON ALL SEEDS by the packet, ounce or pound, or fraction thereof, on receipt of price given in catalog.

FOR HEAVY SEEDS, such as Peas, Beans and Corn, add 5c per pint, and $8 \mathrm{c}$ per quart, to prepay postage. Purchaser must also pay charges on express on freight shipments.

USE OUR ORDER SHEET AND ENVELOPE when possible. Write plainly. Keep a copy of your order, and be sure to sign your Name, Postoffice, County and State, every time you write us. We will furnish extra envelopes and order sheets on application.

Cash should accompany the order. 


\section{ASPARAGUS}

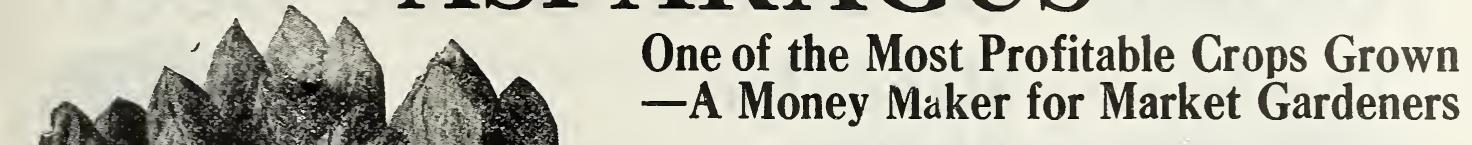

\section{Archias' Great Emperor}

The most remarkable Asparagus ever introduced, originated by Mr. C. L. Allen, one of our most prominent Seed Growers, and produces an immense crop the second year from seed. Mammoth white, tender stalks, one foot long and an inch thick.

Do not fail to try this wonderful vegetable. Pkt., $10 \mathrm{c} ; 2$ pkts, 15c; oz., 20c; 1/4 lb., 45c; $1 / 2$ Ib., $75 \mathrm{c}$.

Columbia Mammoth White-Shoots of the largest size, clear white, without the process of blanching. Superior in flavor and tenderness. Price, per pkt., 5c; 0z., 15c; 1/4 Ib., 35c.

Barr's Mammoth-Large and prolific. Pkt., 5c; oz., 10c; 1/4 Ib., $30 \mathrm{c}$.

Conover's Colossal-One of the best varieties grown. Oz., $10 \mathrm{c} ; 1 / 4$ Ib., $25 \mathrm{c}$

\section{Asparagus Roots}

The purchaser of roots two years old will save two years' time. Best 2-year roots, doz., 20c; 25, 40c; 100, $\$ 1.25$; 500 for $\$ 5.00$. Not prepaid. Leaflets on Asparagus Culture sent free on application.

\section{ASPARAGUS CULTURE}

A book giving all possible details as to Growing, Soil Marketing, Canning, etc., for home use or market. 150 pages $5 \times 7$. Cloth, 50c, Postpaid.

\section{Asparagus Roots and Seeds are a Special-} ty with us. Let us supply your needs.

Archias' Giant Emperor

\section{We Test Our Seeds}

W

E HAVE probably the BEST and MOST COM. PLETE system of SEED TESTING and TRIAL GROUNDS to be found anywhere. We pay partlcular attention to seeds suitable for planting in the CENTRAL WESTERN and SOUTHERN STATES. The Seeds offered by us will not only grow, but will give satisfaction. They are strong in vitality and are procured from properly selected cultivated and are procured from properly selected cultivated and rogued fields and are as good as grow.
ARESEE⿱ ARCHIASSED ARCHIAS" "SURE SEEDS" are known to almost everybody who plant seedsARCHIAS TRADE MARK is on every package and is a guarantee of QUAL. ITY.

\section{Seed Warranty}

Most of the failures with seeds are entirely beyond our control and they render it impossible for us to guarantee success, and therefore we want it plainly understood that while we exercise great care to have all seeds, plants and bulbs, sure and reliable, and also. true to name, we do not give any warranty, express or implied, as to description, quality, productiveness or any other matter, of any seeds, bulbs or plants which we send out, and we will not be in any way re. sponsible for the crop. No officer, agent or employee of this company is authorized to make any warranty whatsoever. If the purchaser does not accept the seeds, bulbs or plants on these conditions notify us at once, and we will give instructions for disposition of same, and the money that has been paid for same to us will be promptly refunded. It is to our interest, however, to have everything of the highest quality obtainable, and we would not furnish seeds of doubtful quality for several times the price that we receive for them, as it would injure us more than it would the purchaser. However, we have so much confidence in our seeds that we hereby agree to refill any order for vegetable or flower seeds free of charge should they prove otherwise than as we represent them. We know of no responsible seed firm which guarantees seeds any further than this. Compare with other catalogues and you will find that we are right.

\section{Missouri State Fair}

This is not the oldest, but is undoubtedly the BEST STATE FAIR In the UNION. Our customers should visit the Missouri State Fair which is held at Sedalia the first week in October of each year in elegant new fire-proof buildings. Big premlums are offered in every department and competition is open to the world. We want every planter of Archias' "Sure Seeds" to grow something for thls Fair-and come yourself-make your head'quarters at Archias' Seed Store and at our Greenhouses where YOU will always be WELCOME. Thus we will become better acquainted. Rooms and other accommodations will be secured on request. Do not hesitate to write us.

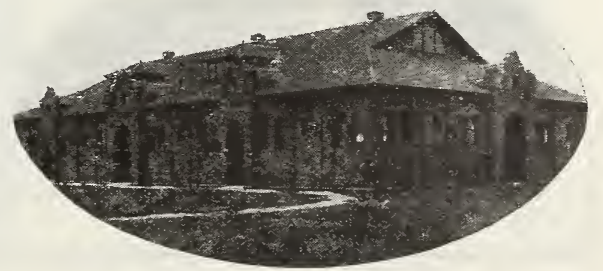


GROW "SURE SEED S," PLA N T A N D TREES

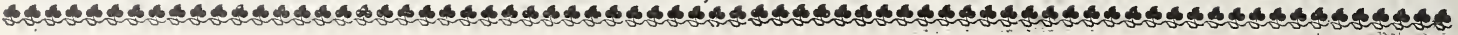

\section{Archias' Crimso
The Money Maker for Market Gardeners}

A quick seller, smooth skinned, slightly oblong, deep crimson color, and of the very finest quality, sweet and tender, being entirely free from stringiness Small, dark bronzed foliage, admitting of close and easy culture. When washed and bunched for market the rich color and oval shape
SE ARCHSSEE shows the beautiful varlegation of the cut beet, yet, when cooked, it is of even, solid dark red. Every gardener should plant this new, excellent beet. Pkt., 10c; oz., 15c; $1 / 4$ Ib., 50c; Ib., $\$ 1.90$, Postpaid.

ARCHIAS' IMPROVED BLOOD TURNIP-Fine turnip form, very symmetrical in shaps, and free from any fibrous roots. Flesh deep blood red, very tender and sweet; grows uniformly to a good size. Medium early, and when sown late desirable for winter. Pkt., 5c; oz., 15c; 1/4 lb., 50c; 1 lb., $\$ 1.75$.

CROSBY'S EGYPTIAN-Improved strain of the Egyptian beet. Quite as early, of better color and quality, and smoother than the Egyptian. Pkt. 5c; Oz., 15c; I/4 Ib., 50c; 1 Ib., $\$ 1.75$.

\section{Globe Beet}

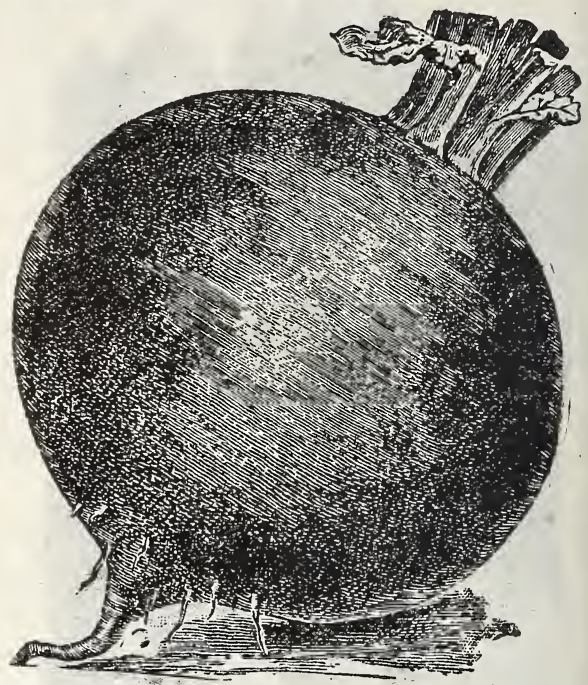

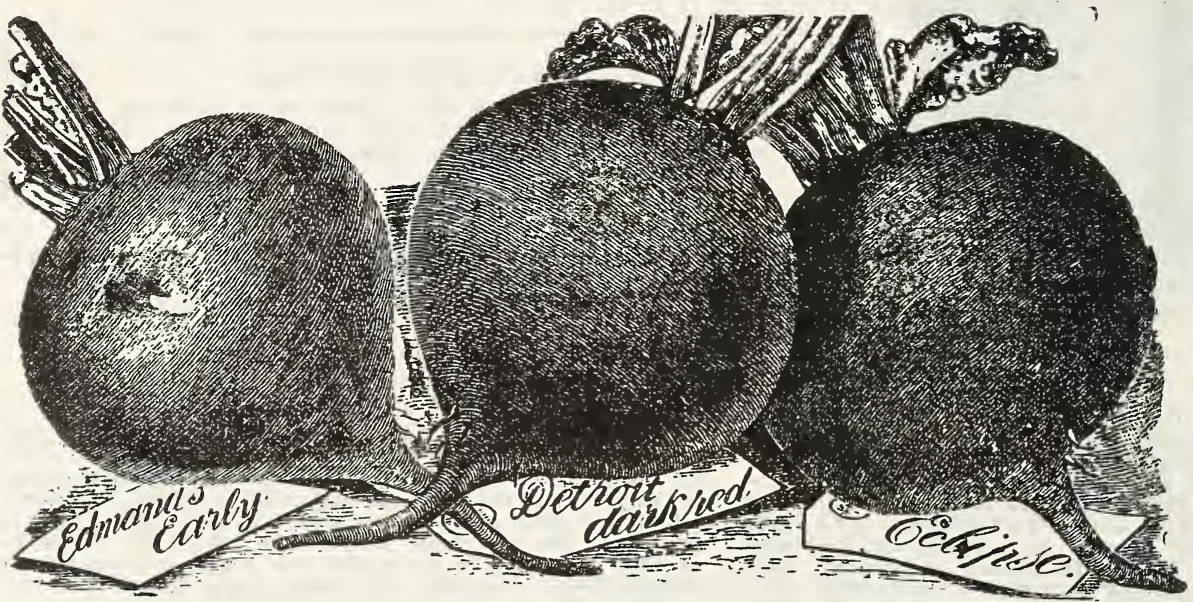

EXTRA EARLY EGYPTIAN TUR NIP-Early, deep crimson color. Pkt. 5c; Oz., 15c; i/4 Ib., 50 c; 1 Ib., $\$ 1.75$.

EDMONDS EARLY BLOOD TURNIP - Exceedingly dark; shape globular; popular with market men. Pkt., 5c; oz., 15c; 1/4 Ib., 50c; 1 Ib., $\$ 1.75$.

ECLIPSE- Exceedingly popular for its extreme earliness. Bright, glossy red, fine grained and delicious. Pkt. 5c; oz., 15c; 1/4 Ib., 50c;

DETROIT DARK RED-One of the best red turnip-shaped varieties. Has small, upright tops; splendid shape; bright red. Very crisp, tender and sweet; matures early; holds a long time in condition for use. Pkt., $5 c$; oz., 20c; $1 / 4$ Ib., 65c; $1 \mathrm{lb}, \$ 2.25$.

LONG BLOOD RED-Used both for table and stock; resists drouth well; deep red, very sweet, keeps well during winter.

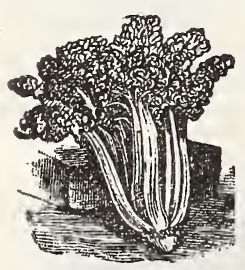

Swiss Chard. Try it. Pkt., 5c; oz., 15c; 1/4 Ib., 50c; 1

\section{Swiss Chard}

OR ASPARAGUS BEET-A new variety, selected especially for its broad mid-ribs and stems. It is usually prepared for the table in the same manner as Spinach; sometimes, however, the mid-rib is prepared like Asparagus, with drawn butter. A row of Swiss Chard will furnish greens the whole summer long. Pkt., 10c; oz., 20c; 1/4 lb., 75c.

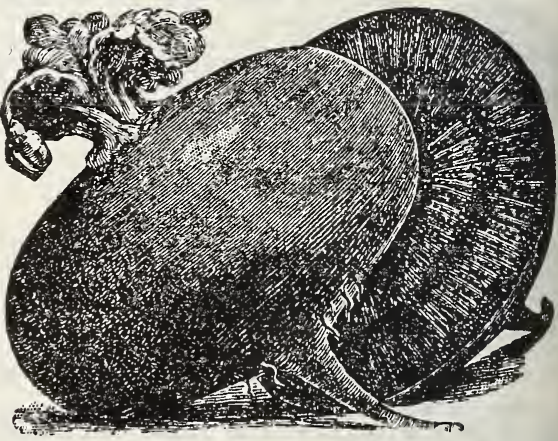

Extra Early Egyptian.

ORDER EARLY-Better have your seeds on hand a few days before you need them than run the risk of their being delayed, for in the planting season thousands of orders must be filled, and sometimes stocks become exhausted. 
A RCHIAS, SEED STORE, SEDALIA, MISSOURI

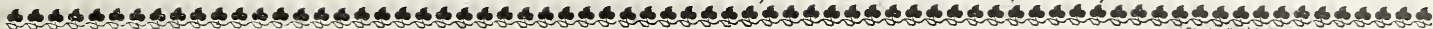

\section{Archias' Wurzels and Sugar Beets}

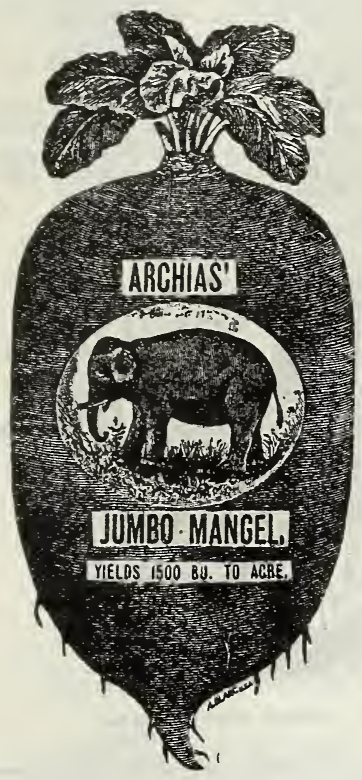

\section{Grown for Feeding Stock}

\begin{abstract}
Archias' Jumbo Long Red Mangel-imniense cropper, yielding 1,500 bushels to the acre. The stock raiser's friend-the money maker-a flesh producer. Finest feed for horses, cattle or sheep: exceedingly nutritious and a healthful feed. Nothing will reat it for winter feeding. Every farmer should plant it. Oz., 15c; $1 / 4$ Ib., $50 c$; $1 / 2$ lb. 90c; 1 lb., \$1.65; 5 lbs., \$7.50, postpaid.

Archias' Mammoth Golden Giant-Remarkably even in shape, rather elongated, of vigorous growth, and a very smooth skin. Flesh white, firm and sweet, much liked by cattle: easily lifted from the ground; producing enormous crops. Fxcellent keepers: yields 40 to 60 tons per acre. Pkt. $5 \mathrm{c}$; oz., 15c; $1 / 4$ Ib., 50; I/2 Ib., 90c; 1 lb., $\$ 1.65$; 5 lbs., $\$ 7$. 00 , postpaid.
\end{abstract}

Norbitan Giant, or Red Mangel-A good productive variety. Oz., 15c; $1 / 4 \mathrm{lb}, 50 \mathrm{c} ; 1 \mathrm{lb}$ $\$ 1.60 ; 5$ Ibs., by express, $\$ 7.00$.

Golden Tankard Mangel Wurzel-One of the best stock beets. Oz., 15c; 1/4 lb., 50c; 1 lb., \$1.60; 5 Ibs., by express, $\$ 7.00$.

Imperial White Sugar-Good for making suga: and stock teeding. A hardy and productive sort. Oz., 15c; 1/4 lb., 50c; 1 lb. $\$ 1.65 ; 5$ lbs., by express, $\$ 7.00$. Special prices to parties raising large quantities of k,eets for stock.

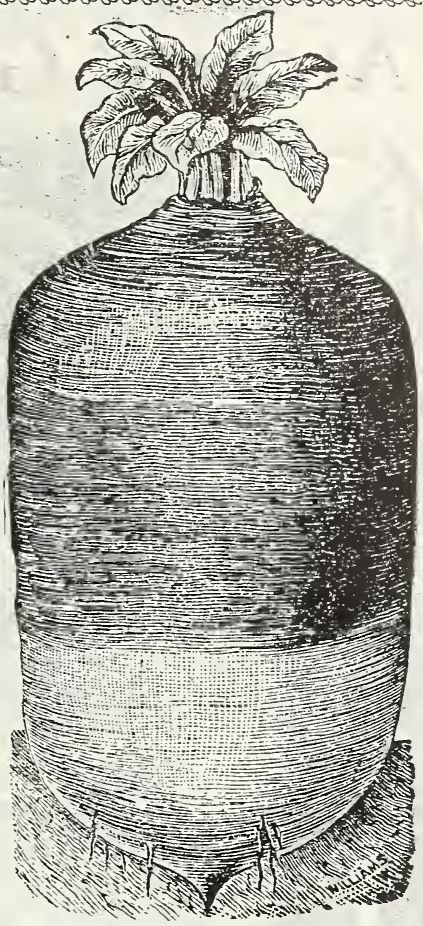

Mammoth Golden Giant

\section{Archias' Select Table Carrots}

French Forcing-This is the earliest carrot; small, round roots, Pkt., 5c; oz., 15c; $1 / 4$ Ib., 50c; lb., \$1.65, postpaid.

Early Scarlet Horn (Blunt Root)-Recommended both for family and market gardeners. Fine flavor. Oz., 15c; 1/4 Ib., 50c; 1 Ib., $\$ 1.75$.

Oxheart (Stump Rooted)-Three or four inches in diameter; flesh bright orange; fine grained and sweet; very productive. Where other varieties require digging. Oxheart can be easily pulled. Oz., $15 \mathrm{c} ; \mathrm{1} / 4$ Ib., 50c; 1 Ib., $\$ 1.75$.

Red St. Valery-Originated in France, where it is a popular variety. Rich, deep orange color large and handsome. Very straight roots, broad at the top. Superior for table and desirable for stock. Pkt., 10c; oz., 15c; 1/4 Ib., 50c; 1 Ib., $\$ 1.75$.

Danver's Half Long SrarletRich orange red, very smooth and handsome; excellent market variety. Oz., 15c; $1 / 4$ Ib., 50c; 1 Ib. $\$ 1.75$.

Long Orange-A large led, popular varièty for winter $115 \mathrm{E}$. Oz. $15 \mathrm{c}$; I/4 Ib., 50c; 1 lb., $\$ 1.75$.

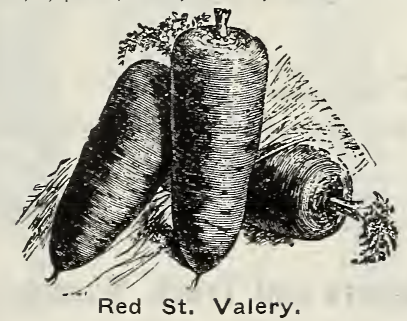

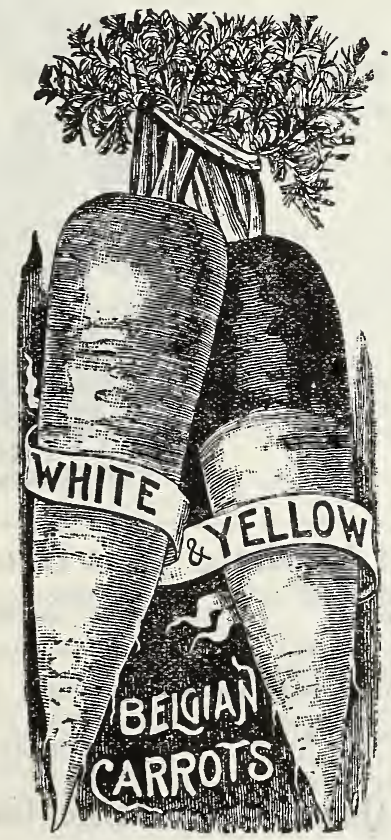

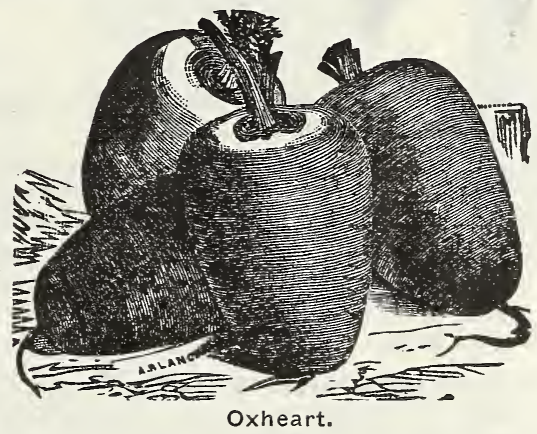

Scarlet Intermediate-A thick; intermediate, smooth variety; an English sort; very much resembles the Danver's Carrot in both general shape and size. The color is a rich orange-red, and of fine flavor. The roots grow very uniform; a most desirable carrot for private gardens, or market purposes. Pkt. $10 \mathrm{c} ;$ oz., 15c; I/4 Ib., 50c; Ib., \$1.75.

\section{Carrots for Stock}

White Belgian Root pure white, will grow to a very large size. Flesh coarse; rather exclusively for stock Oz., 15c; 1/4 Ib., 50c; 1 Ib., \$1.75; 5 lbs., by express, $\$ 7.00$.

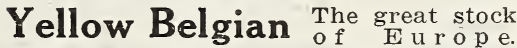
Enormously productive, nutritious and splendid keepers. Oz., 15c; 1/4 1b., 50c; 1 1b., $\$ 1: 75$; 5 lbs., by express, $\$ 7.00$. 
G R O " "S U R E S E D S,', PLA N T A N D T RE E

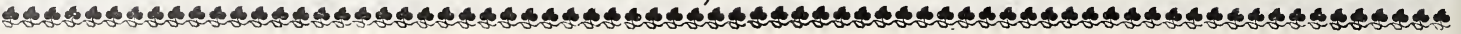

\section{Archias' Green Podded Bush Beans}

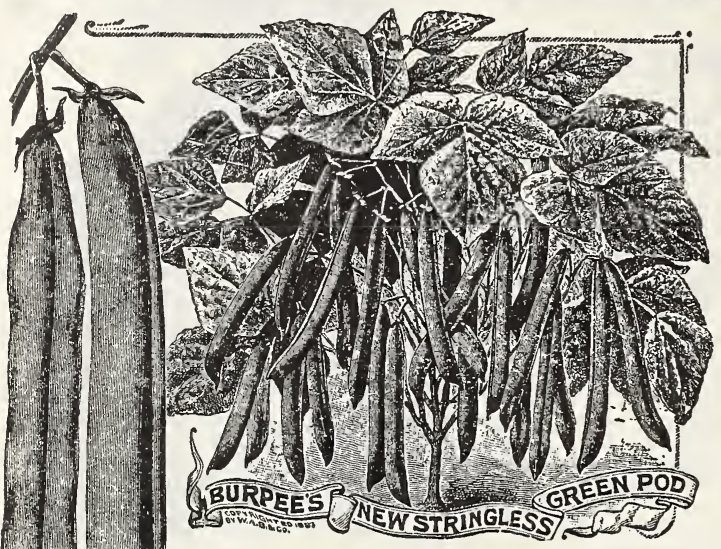

Burpeee's Stringless Green Pod-The earliest and only absolutely stringless green-podded bean. Pod round, full, large and straighter than that of Red Valentine. Quality superior to most other bunch beans. Pkt., 15c; pt., 40c; qt., 75c. 4 qts., \$2.50.

Improved Red Valentine-Popular variety, green pod, productive, Pkt., $15 \mathrm{c} ;$ pt., $40 \mathrm{c}$; qt., 65c; 4 qts., \$2.25.

Long Early Yellow Six Weeks-Well known long, green pod; productive. Pkt., 15c; pt., 40c; qt., 65c; 4 qts., \$2.25.

Refuge, or 1,000 to 1 -One of the earliest of green podded sorts; used for pickling; pods long, cylindrical; prolific. Plkt., $15 \mathrm{c} ;$ pt., 40c; qt., 65c; 4 qts., \$2.25.

White Marrowfat - Exclusively a shelling bean; exceedi $n$ g l y p r o d u ctive; cooks mealy and tender bean large. Pkt., 15e; pt., $35 \mathrm{c} ;$ qt., $60 \mathrm{c}$

Archias' Boston Navy Bean-This is a wonderfully productive bean with stiff bush and fine quality and appearance. Without question the heaviest yielding bean known. Our stock is carefully selected. Be sure to include this. Pkt., 10c; pt., 25c; qt., 45c; 4 qts., \$1.50.

California Bunch or Prolific Tree-A valuable variety for field culture, 20 inches high, stiff, upright branches, often yields 45 bushels to the acre. The bean resembles the white navy. Pkt., 10c; pt., 25e; qt., 45e; 4 qts., $\$ 1.50$.

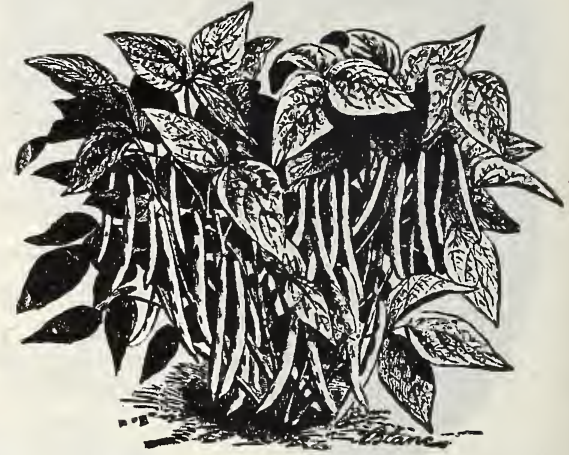

Archias' Boston Navy Beans.

\section{Archias' Select Wax Bush Bean}

Beans are very scarce this season, so advise our customers to order early.

Archias's Improved Rust Proof Golden Wax-Improved strain of the well known Golden Wax, which it has greatly outyielded. Pkt., 20c; pt., 45c; qt., 85c; 4 qts., \$3.00.

Improved Dwarf German Wax (Black Seeded)-A popular variety of unusually good merit, color of pod waxy yellow; tender, productive. Pkt., 20c; pt., 45c; qt., 85c; 4 qts., \$3.00.

Davis' Kidney White Wax-The best white seeded Wax Bean, of handsome appearance, and seils well in market. The pods are long, straight, waxy white. It holds its pod well up from the ground. Pkt., 20c; pt., 45c; qt., 85c; 4 qts., $\$ 3.00$.

Wardwell's Kidney Wax-The vines are very large, strong growing and vigorous, yielding very white waxlike pods. Ripens with the Golden Wax. Pkt., 20c; pt., $45 \mathrm{c} ;$ qt., $85 \mathrm{c} ; 4$ qts., $\$ 3.00$.

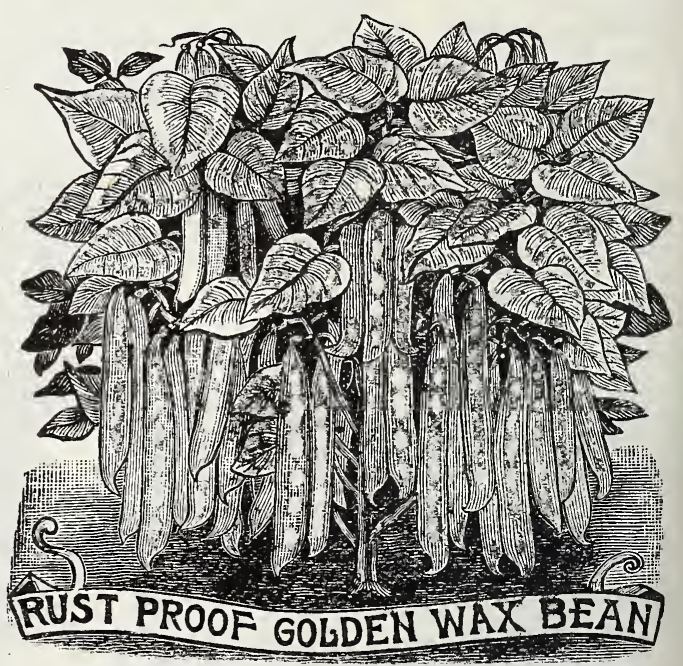

\section{Do Not Mutilate This Book}

Please do not cut the illustrations from this book to enclose with orders, as it is entirely unnecessary.

If you will give us the name of the article, quantity, size and price wanted we can correctly fill your order.

ARCHIAS' SEED STORE CORPORATION, FOR THIR'TY YEARs wo have supplied the best Market Gardeners, Farmers and Florists with Archias' "Sure of letters of appreciation from pleased customers-friends

Write for Special Quotations in Quantities to Market Gardeners and Truck Farmers. 
A R CHIA , SEED STORE, SEDALIA, MISSOURI

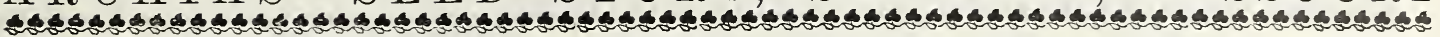

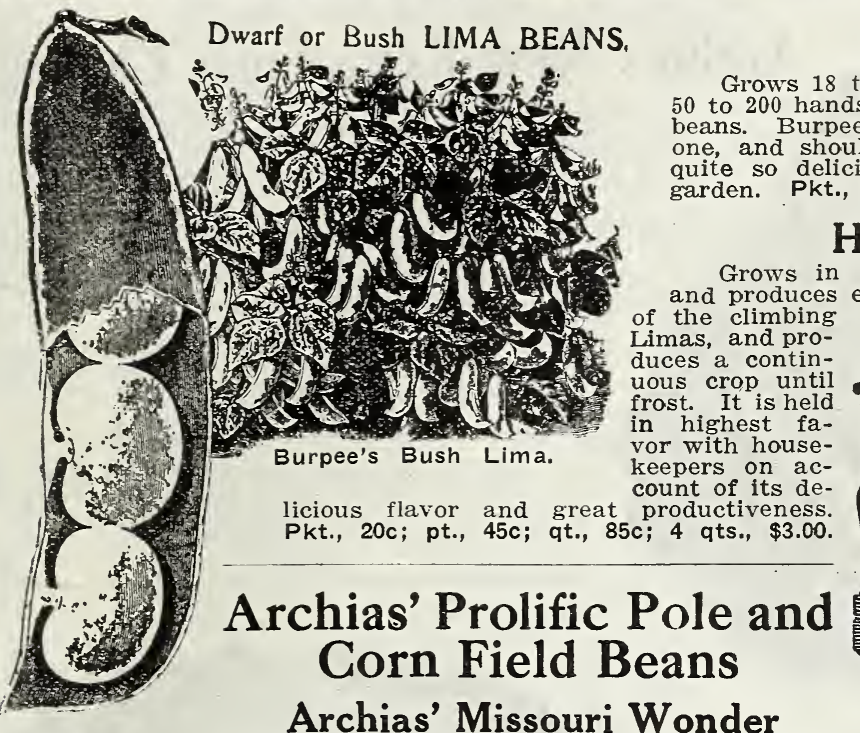

\section{Burpee's Bush Lima}

to 30 inches high, each bunch bearing from

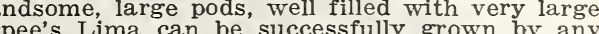
should be in every garden, as there is nothing (1) garden. Pkt., 20c; pt., 45c; qt., 85c; 4 qts., $\$ 3.00$.

\section{Henderson's Bush Lima}

Grows in compact bush from 15 to 18 inches high, of the climbing Limas, and produces a continfrost. It is held n highest fakeepers on account of its de-

licious flavor and oreat Originated in Missouri and is undoubtedly the most wonderful
bean in existence. It is enormously prolific and so hardy pole bean in existence. It is enormously prolific and so hardy remained on the ground all winter. It will grow and bear

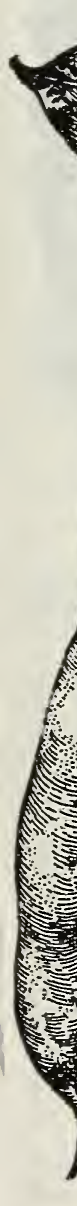
an abundant crop in spite of bad weather. Pods are light green, large and tender, stringless if plcked young. Fine for shell beans or succotash if let gruw. Include Archias' Missouri Wonder in your order. Large postpaid, postpaid. Not c: pt, 45c; qt., $85 c$; 2 qts., $\$ 1.60$.

\section{Kentucky Wonder}

It is enormously productive, the pods hanging in great clusters from top to bottom of pole. It is entirely stringless, and the pods are a silvery green color. The pods though large, cook tender and melting. Per Pkt., 15c; pt., 35c; qt., 65c 4 qts., \$2.25.
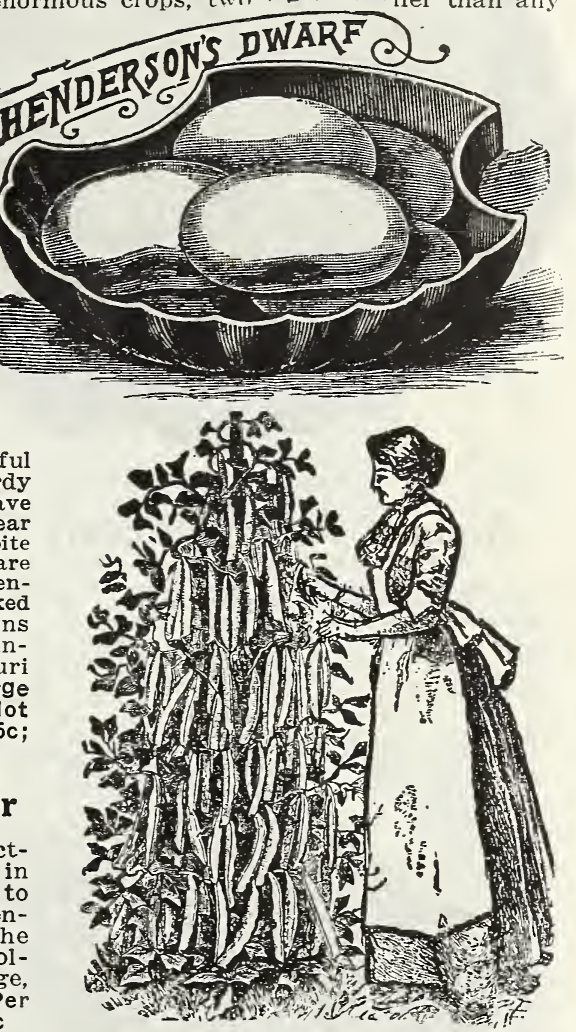

Archias' Missouri Wonder

\section{Cut Short Red Speckled}

(Oval Seeded)-Good corn field variety; good cropper, reliable, popular. Pkt., 15c; pt., 35c; qt., 65c; 4 qts., \$2.25.

Golden Cluster Wax-A valuable wax pole bean vigorous, prolific and tender; also an excellent shell bean. Beans are large and white. Pkt. $20 \mathrm{c}$; pt., $45 \mathrm{c}$; qt., $85 \mathrm{c}$; 4 qts., $\$ 3.00$.

Crease Back or Fat Horse-Wonderfully productive, pods long and stringless, bears 4 to 12 pods in a cluster. Pkt., 15c; pt., 35c; qt., $65 \mathrm{c}$ 4 qts., \$2.25.

White Dutch or Case Knife-Snaps well when young, excellent for shell beans for winter use, yields well. Pkt., $15 \mathrm{c}$; pt., $35 \mathrm{c}$; qt., $65 \mathrm{c} ; 4$ qts. $\$ 2.25$.

Horticultural Cranberry-Beans oval, speckled; a popular variety, equally serviceable in the green state or shelled. Pkt., 15c; pt., 35c; qt., 65c ; 4 qts., $\$ 2.25$.

\section{Lazy Wife}

The pods of a medium dark green color, are produced in great abund ance, and measure from $41 / 2$ to 6 inches in length; they are broad, thick, very fleshy. Pkt., 15c; pt., 35c; qt., 65c; 4 qts., \$2.25.

\section{Three Best Pole Lima Beans That Pay to Plant.}

Small White LIma, or Sieve-Vines vigorous, very early and productive, pods short, beans white. Pkt., 15c; pt., $35 \mathrm{c}$; qt., $65 \mathrm{c} ; 4$ qts $\$ 2.25$.

KIng of the Garden Lima-A very large sort, considered most productive of the Limas. Pkt., 15c; pt., 35c; qt., 65c; 4 qts., \$2.25.

Large Whlte Lima or Butter-Most universally grown, both for marKentucky Wonder 
G R O W "S U R E E E S,', P L A T S A N D T R E S

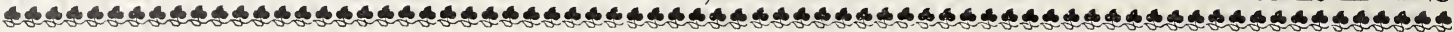

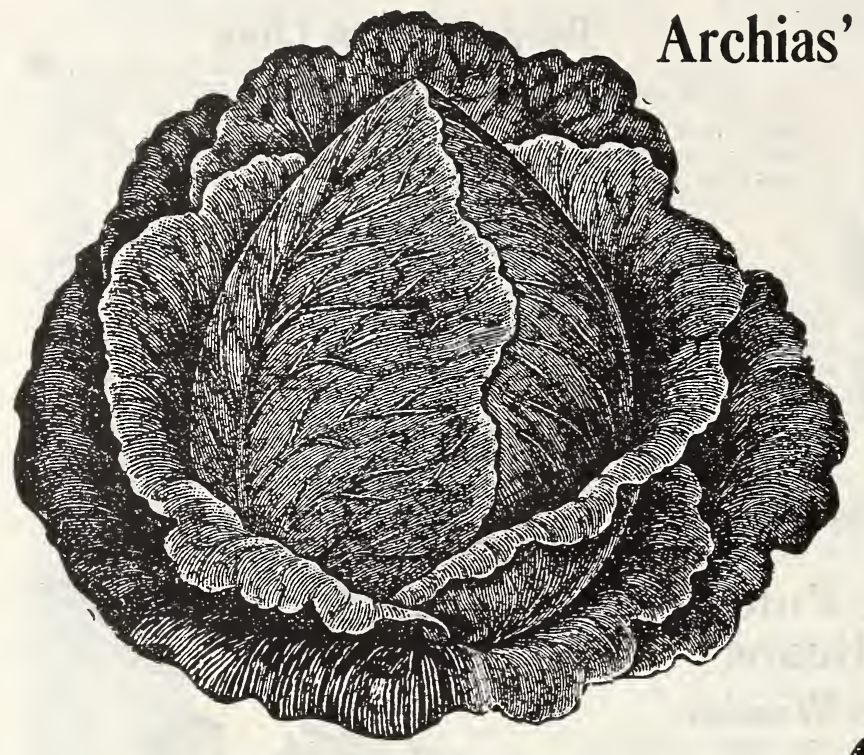

\section{Archias' New Extra Early Cabbage}

Earliest Hard Heading Cabbage in the World. Succeeds Everywhere-The Big Money Maker for Market Gardeners. Every plant makes a head. This new and very early cabbage, while not as earlier, and for a first early variety cannot be excelled. Solid, compact heads of conical form, dwarf and very uniform. Desirable as a quick forcing sort. Every cabbage grower should plant the Archias' Extra Early for their first cabbage.

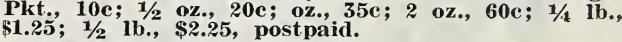

Cabbage-How to Raise Them-A practical treatise on cabbage culture, giving full details on every point, including keeping and marketing

Archias' New Extra Early.

Archias' All Head Early Cabbage ALL HEAD AND ALWAYS SURE TO HEAD. This Cabbage is a few days later than our Famous New Extra Early, but twice its size. If a gardener, or an amateur, were to plant but one variety of cabbage, he could get none that would answer all purposes as well as Archias' "Al, Head." For uniformity, reliability of heading, size, earliness and quality it has no equal. It a close planting can be made and 1,000 more cabbages per acre can be grown than from seeds of other sorts. Pkt., 10c; oz., 35c; $1 / 4$ lb., $\$ 1.25 ; 1 / 2$ lb., \$2.25; 1 lb., \$4.25, postpaid.
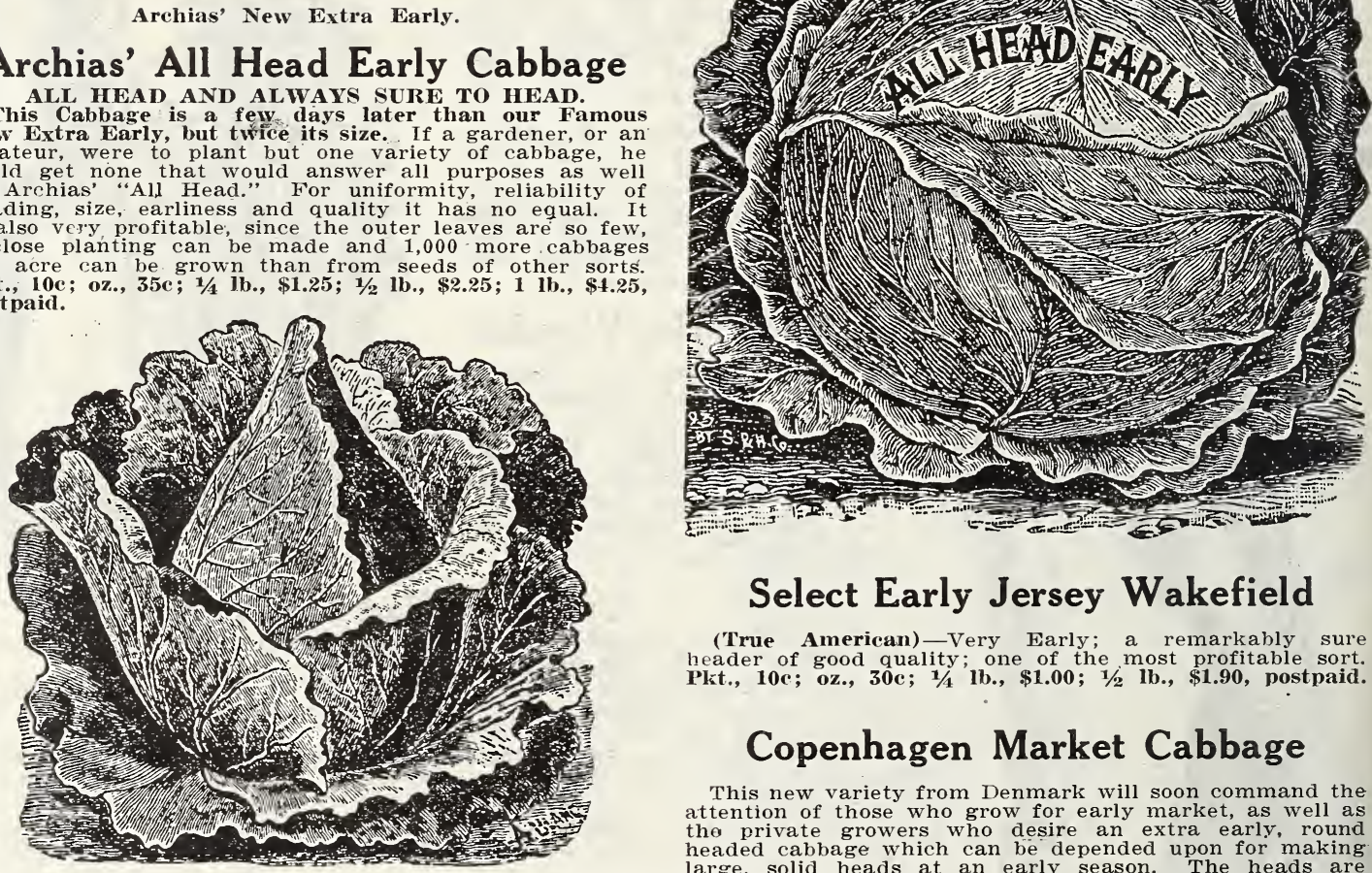

Reduce the high cost of living by enlargng your garden this year. A few dollars meded in seeds may mean the saving of a hundred dollars or more this summer.

Select Early Jersey Wakefield.

\section{Charleston or Large Wakefield}

extra sclected sort, producing large solid heads of good quality; a few days later than the Early Wakefield.

\section{Free Leaflet}

CABBAGE AND CAULIFLOVER-Tells all about their culture. Sent free only with orders. If you want one, ask for it.

We make a specialty of the finest flower pots and jardinieres for florists and amateurs. A large assortment at all seasons of the year. Give us your orders. 
A R CHIA , SEED STORE, SEDALIA, MISSOURI

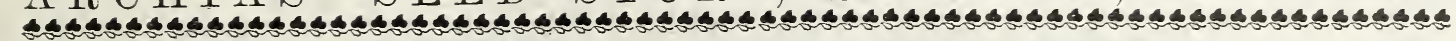

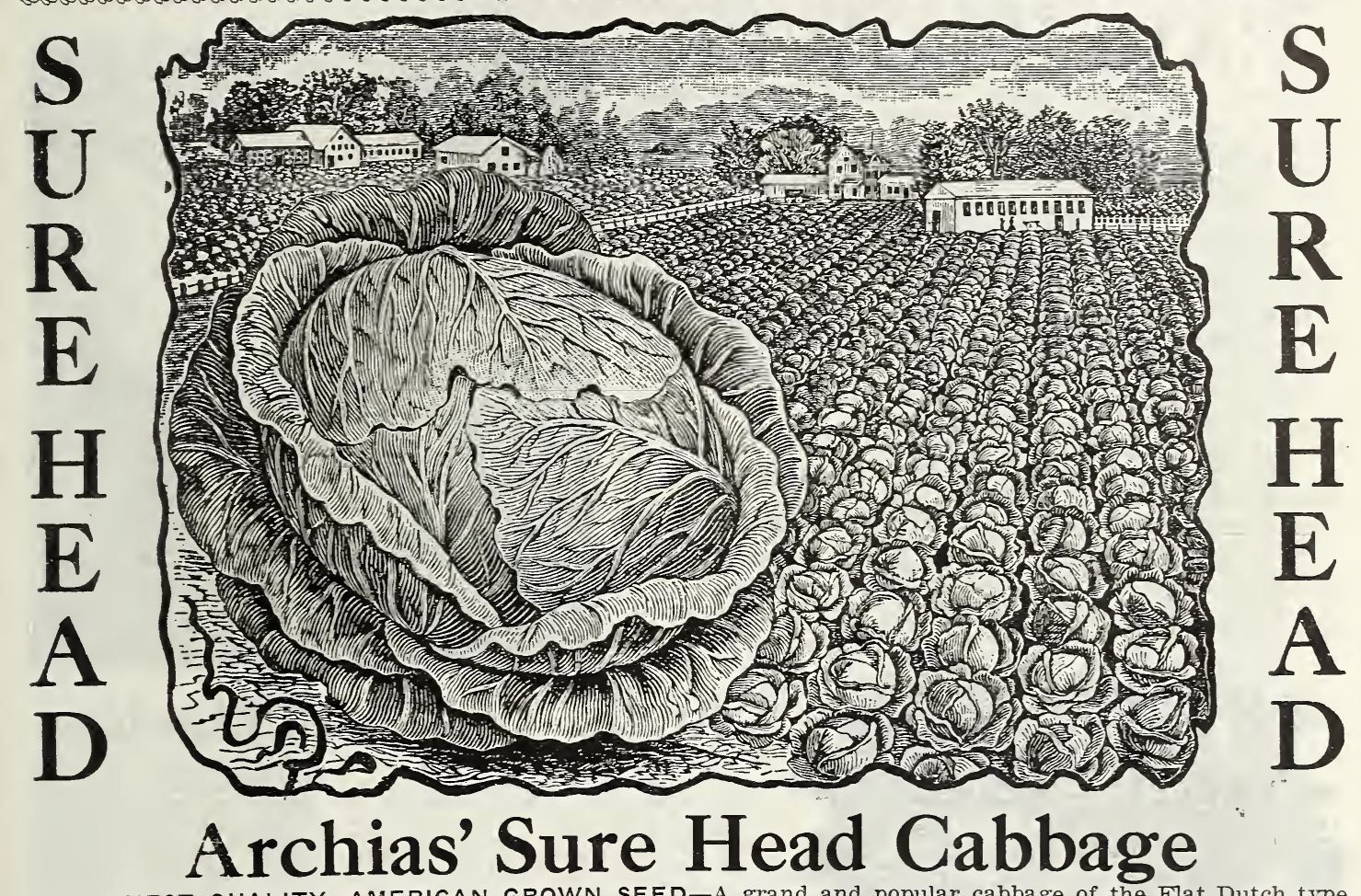

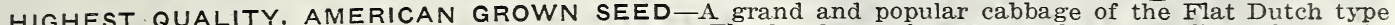
and certain to head however, hot and dry the weather. The heads are large, very hard and firm of texture, fine grained, and of most excellent quality. $\$ 1.25$.

\section{Archias' World Beater}

AHEAD OF EVERYTHING

A grand new white Cabbage originated by our Long Island grower; larger than our Mammoth Marblehead; very uniform in size and shape, and solid as a rock. The best and largest testimonials we received last season from planters of this wonderful Cabbage would fill

Do not fail to try it. Price of Archias' World Beater Cabbage, per pkt., 10c; $1 / 2$ oz., 25c; cz., $45 \mathrm{c}$ : $1 / 4$ lb., $\$ 1.50$, postpaid.
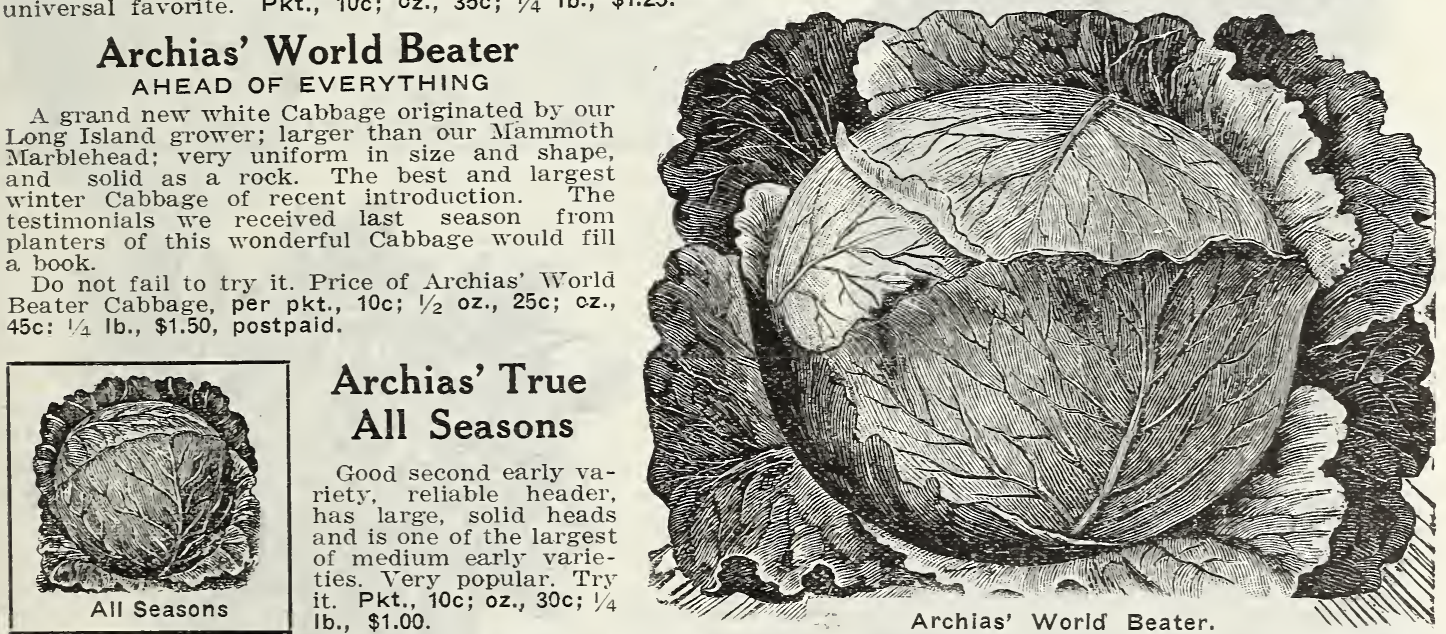

Archias' Chinese or Celery Cabbage, a wonderful novelty. Pkt., 10c. See first inside cover page.

ARCHIAS' IMPROVED

Large Late Flat Dutch

A superior strain of the Late Flat Dutch Cabbage, grown exclusively for us. This variety will never fail to give entire satisfaction to the grower; is uniform Pkt., 5c; oz., 30c; 1/4 Ib., $\$ 1.00$; postpaid.

St. Louis Late Market Cabbage A popular late Cabbage with the St. Louis market gkt., 10c; oz., 35c; 1/4 ib., $\$ 1.25$ postpaid.

\section{Other Choice Late Varieties}

DANISH BALL HEAD, or Holland Cabbage-Heads as round as a ball, of good size, solid and
grained. Pkt., $10 \mathrm{c}$; oz., $30 \mathrm{c}$; $1 / 4$ lbs., $\$ 1.00$.

MAMMOTH LATE RED ROCK-This variety is for picking of a deep purple color: Pkt., $10 \mathrm{c}$; Oz., $30 \mathrm{c}$.

LARGE LATE AMERICAN DRUMHEAD-Heads large, round and compact; good for fall and winter ib., $\$ 1.25$
ib. 
GROW' "S U R E SE E S,', P L A N T A N D T R E S

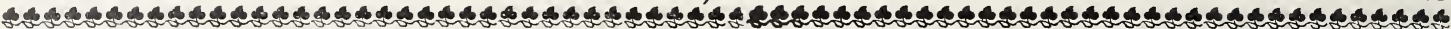

\section{CAULIFLOWER}

Cauliflowers delight in a rich, moist soil, and in dry seasons should be abundantly watered, especially when heading. Sow the seed early in the hotbed and transplant the plants 2 to 3 inches apart in boxes or in another hotbed until such times as they are safe to be planted in the open ground, which in this latitude is usually the 10th of April. Set the plants in the field $15 \times 24$ inches apart.

An extremely early dwarf variety, grown for us by the best Cauliflower specialist in Denmark, producing magnificent white heads of the fine quality; well adapted to hotbed or open ground culture. Pkt., 15c; 2 pkts., 25c; 1/1 oz., 75c; oz., \$2.50; 14 lb., $\$ 8.00$.

EXTRA EARLY DWART ERFURT-The favorite German variety. Dwarf habit, compact growth, short outside leaves; can be planted twenty inches apart. Plkt., 15c; 2 plkts., 25c; 1/4 oz., $75 \mathrm{c} ;$ oz., $\$ 2.50 ; 1 / 1$ 1b., $\$ 7.50$.

Larly Paris-Later and not so good as Snowball. Plk., 5e; 1/1 Book, "Cáuliflower and How to Grow Them," postpaid, 20c.

\section{CELERY The Finest Early Varieties}

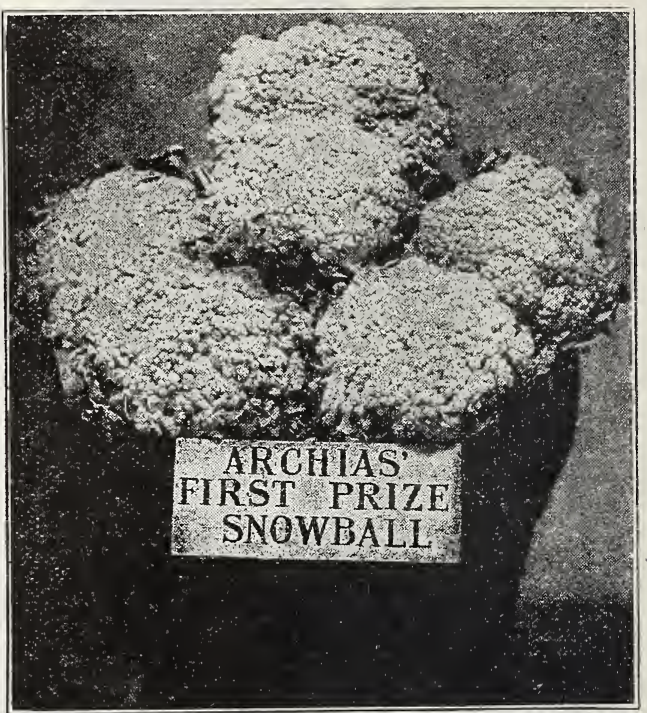

Culture-Celery can be successfully grown with but little labor in any good garden soil, if plenty of well-rotted manure or high-grade fertilizer is used. It delights, however, in low, moist, rich bottom land, or well drained muck soil. It is usually grown as a second crop. FREE LEAFLET ON CELEIRY-Explains culture, sent free, if asked for with your order.

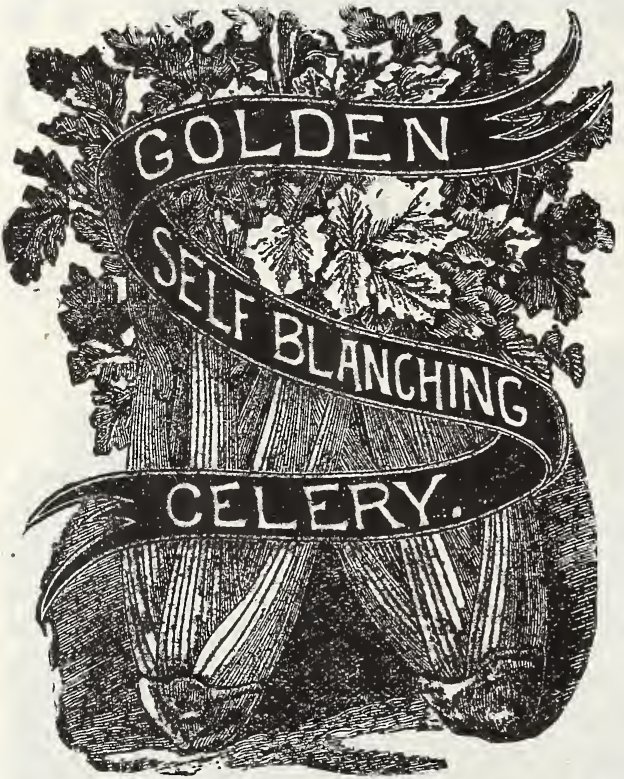

\section{Archias' Golden Self Blanching}

The finest and best early self-blanching variety. The ribs are perfectly solid, crisp, brittle and of delicate flavor, surpassed by no other variety; while it has the decided merit of being self-blanching to a very remarkable degree. Our stock of this variety is selected with special care in France. It is the strain $25 \mathrm{c} ;$ oz., 45e; 1/4 lb., \$1.60; 1/2 1b., \$3.00; 1 lb., \$5.75.

\section{WHITE PLUME---See Illustration}

The plants grow rapidly and blanch easily during the summer months. The central stalks and leaves are pure snowy white, centring up but st gether and earthed up as in other va attractive bunches. Pkt., 10c; $1 /, 0 z, 20 c ; 0 z, 35 c ; 1 / 41 b ., \$ 1.00$ $1 / 2$ lb., \$1.75; 1 lb., \$3.25, postpaid.

CELERY-WINTER VARIETIES. because of its weighty prod u c t iveness and conseand quent profitableniess. Per Plkt., 10c; oz., 30c; 1/4 1b., $\$ 1.75$; per lb., $\$ 3.25$.

Giant White Solid - Fine, large $\mathrm{siz}$ tall and stiff growth. Oz., 30c; 1/4 1b., \$1.00; 1/2 1b., \$1.90; 1 1b., \$3.75. Celeriac, or Turnip liooted-The roots grow like turnips, and when cooked and sliced in vinegar, make excellent salad. Oz., $25 \mathrm{c} ; 1 / 4 \mathrm{lb}$., 75c; $1 / 2 \mathrm{lb} ., \$ 1.25 ; 1 \mathrm{lb}$., \$2.25.

BOOK-“Celery for Profit," by T. Greiner. The Celery industry has recently very greatly increased, and this delicious vegetable is now found on nearly every table. The newer improved methods of culture are described in this volume. Postpaid, 30 cents.

Fine Curled (Pepper Grass)-Quick growing; leaves nicely cut and feathery; like a good parsley; growth dwarf; ornamental, crisp and pungent; very refr

Water Cress-Leaves very tender and highly flavored. Oz.. 45c.

CHIVES

Small plants of the onion family used for seasoning. Clumps, each, 15c; 2 for $25 \mathrm{c}$; 5 for $50 \mathrm{c}$, postpaid.

Large Rooted or Coffee-The dried roots of this are much used in Europe as a substitute for coffee. Pkt., 10c; oz., 20c; 1/4 lb., 65c.

A substitute winter lettuce; hardy and of quick growth. Sow in fall and mulch to protect for winter use. Pkt., 10c; oz., 20c; $1 / 4$ 1b., 75c.

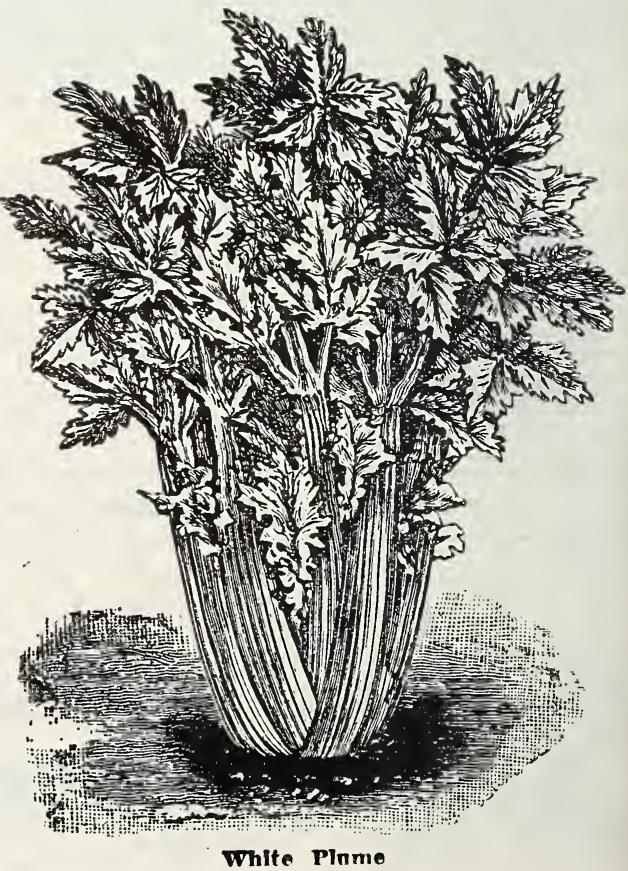

White Plnme 


\section{Archias' Sweet or Sugar Corn}

Let the weather have become warm and settled before planting Sweet Corn. If put into the ground too soon the seed will be apt to rot. To secure succession during the season there should be planted some early, medium and late varieties. Our seed is very carefully selected and has been tested for germination.

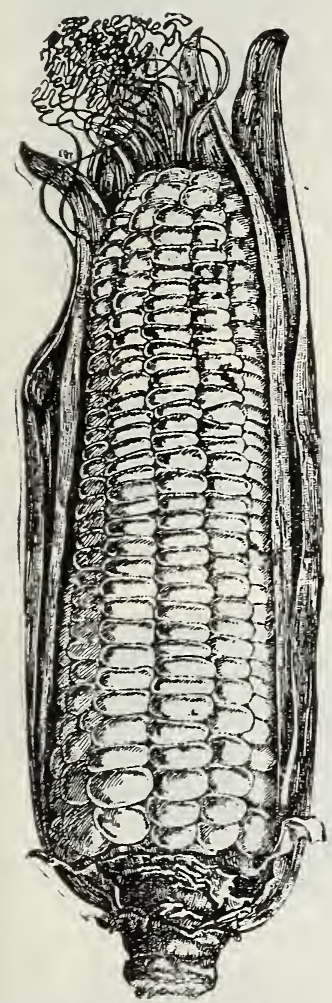

Early Minnesota.
EXTRA EARLY RED CORY Will produce good ears for boiling 52 days from planting. Pkt., 10c; pt., $30 \mathrm{c}$; qt., $40 \mathrm{c}$; 4 qts., $\$ 1.25$; 'pk., $\$ 2.25$.

\section{GOLDEN BANTAM}

Extremely early yellow, eight-rowed triety of delicious flavor. Very sweet. ikt., 15c; pt., 35c; qt., 50c; 4 qts. $\$ 1.50$

\section{EARLY MINNESOTA}

A standard early variety, of strong growth. Ears larger than the Cory, and matures between that variety and the Crosky. Eight rows of quite large sweet grains. Pkt., 10c; pt., 20c; qt. $35 \mathrm{c}$; 4 qts., \$1.25; pk., \$2.25.

\section{EXTRA EARLY ADAMS}

Hardiest and earliest variety, but not a Sweet Corn; stalks 3 to 4 feet high. Pkt., 10c; qt., 25c; 4 qts., 90c; pk., $\$ 1.75$.

\section{ADAMS EARLY}

Equally as hardy and can be planted early in the spring when the trees are starting out in leaf. The stout stalks grow six to seven feet in height, bearing one large or two medium-size ears, which are filled with fine white grain of excellent quality. Pkt., 10c; qt., 25c; 4 qts., 90c; pk., $\$ 1.75$.

\section{OLD COLONY}

Ears 16 to 20 -rowed, grain very deep and one of the sweetest and best late varieties; a few days earlier than Evergreen; fine for market or canning. Pkt., 10c; pt., 20c; qt., 35c; 4 qts., $\$ 1.25$; pk., $\$ 2.25$.

\section{EARLY MAMMOTH SWEET}

One of the best and sweetest Corns rown; valuable for family use. Pkt. $10 \mathrm{c}$; pt., 20c; qt., $35 \mathrm{c}$; 4 qts., $\$ 1.25$;

\section{BLACK MEXICAN}

The ripe grain is bluish black, the corn, when in condition for table, cooks remarkably white and is very tender. Desirable for family use, especially for second early. Pkts, 15c; pt., 25c; qt., 45c.

\section{MAMMOTH EVERGREEN-LATE}

The largest ear of any. Ripens a little earlier than the Stowell's. Pkt., 10c; pt., 20c; qt., 35c; 4 qts., \$1.25; pk., \$2.25.

\section{LANDRETH'S SUGAR}

Nedium late. An excellent canning and market variety of fine quality; prolific. Pkt., 10c; pt, 20c; qt., 35c; 4 qts., $\$ 1.25$.

\section{COUNTRY GENTLEMAN}

Productive, frequently 3 ears to the plant Ear large; grain narrow and very deep. Pkt., 10c; pt., 20c; qt., 35c; 4 qts., $\$ 1.25$; pk., $\$ 2.25$.

CHICAGO MARKET, OR BALLARD-This is the largest and best early corn in existence; twelve-rowed, white-cobbed and of exceedingly fine quality. Pkt., 10c; pt., 20c; qt., 35c; 4 qts., \$1.25; pk., $\$ 2.25$.

NEW WHITE EVERGREEN-One of the finest Sweet Corns in the world. Ears are very large with long, slender grains; delicious, sweet flavor. Pkt., 10c; pt., 20c; qt., 35c; 4 qts., $\$ 1.30$; pk., $\$ 2.50$.

STOWELL'S EVERGREEN-A very sweet, late, remaining a long time in boiling condition; very productive, having very large ears. Pkt., 10c; pt., 20c; qt., 35c; 4 qts., \$1.25; pk., \$2.25.

EVERGREEN FODDER CORN-Excellent for early feed; very profitable. Pk., $\$ 2.00$; bu., $\$ 7.50 ; 2$ bu., $\$ 14.00$. Sacked free.

Field Corn and Pop Corn-See Field Seeds.

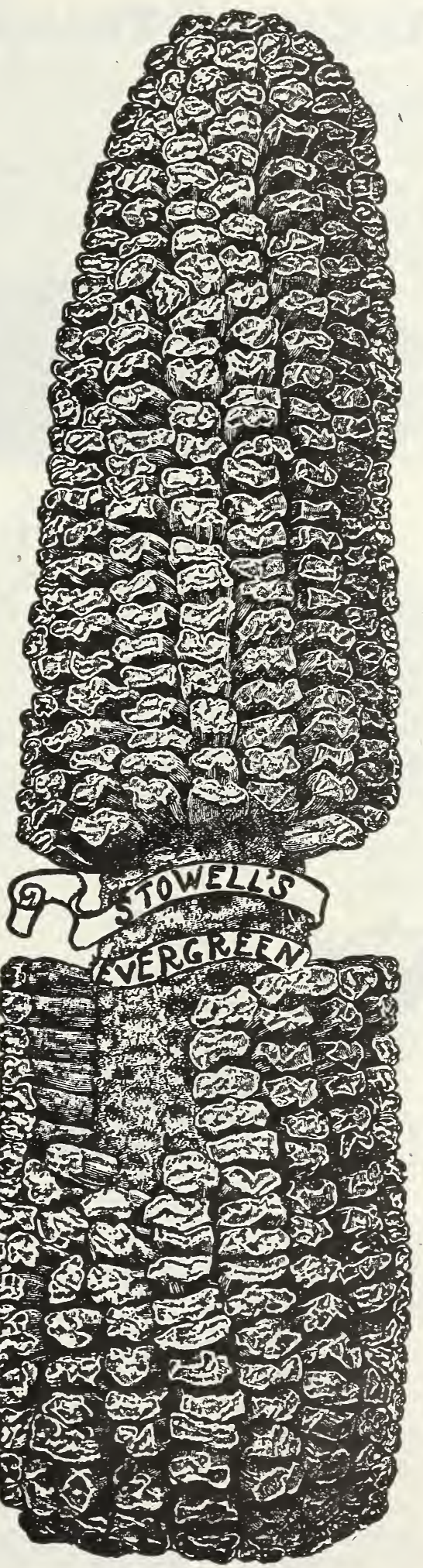


GROW "SURE SE E D S," P L A N T S A D T REE

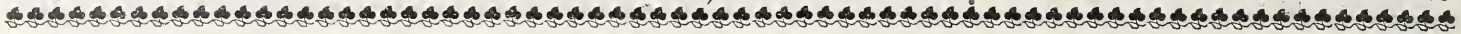

\section{ARCHIAS' PROLIFIC CUCUMBERS}

Carefully Selected Strains, True to Name and Very Best for Table and Pickling. CULTUIRE-Do not plant cucumbers before danger of frost has passed, as the plants are very tender and the, least frost will damage them or kirr them. Plant in hills or rows four feet apart, 10 to 15 seeds to each hill, make soil very rich. For pickles, plant from June 1 st to middle of July.

\section{Archias' Improved Early White Spine}

This special strain of White Spine Cucumber is noted for its extra earliness; earlier-than Fordhook or Arlington. Vines vigorous, fruiting early and abundantly; fruit uniformly straight and hanctsome, dark green, with a few white spines; flesh tender and of excellent flavor. Great bearer for table use or pickling. Pkt., 5c oz., 15c; $1 / 4$ 1b., 40c; 1 lb., \$1.25.

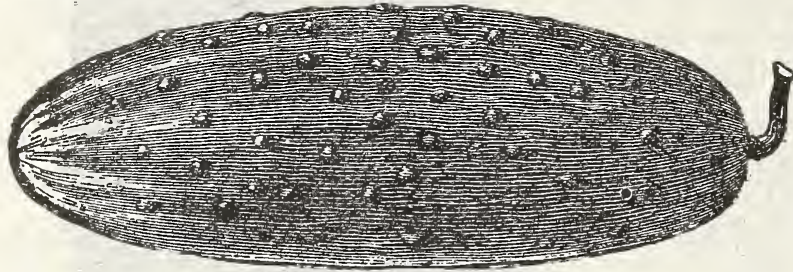

Davis' Perfect

\section{Davis' Perfect Cucumber}

Originated with Eugene. Davis. A sure money maker for those engaged in growing Cucumbers. Grows under glass as well as out of doors. It is as early as Pkt., 10c; oz., 20c; 2 oz., 35c; 1/4 1b., "75c; 1 1b., \$1.50.

I M P I O V E D GREEN PROLIFIC-Very productive, shape long, good for pickling or slicing. Pkt., 1b., \$1.00.

THORNBURN'S EVERBEARING - Small sized, very early, productive and 5c; oz., 15c; $1 / 4$ 1b., 35c; lb., \$1.00.

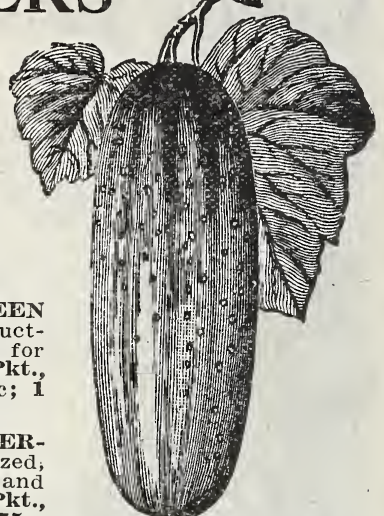

Archias' Improved

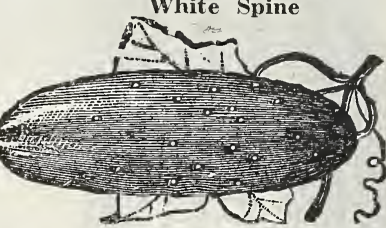

Early Cluster

\section{Archias'}

\section{New Everbearing}

Very early, enormously productive, literally covering the ground with its fruit the entire season until killed by frost, thit is of medium size and rich, dark green in color, shape long, excellent for pickling or slicing Pkt. excellent for pickling or slicing. 1 plkt., lb., \$2.50.

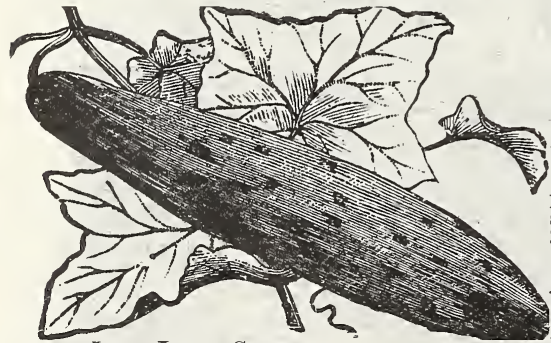

short and Imp. Long Green

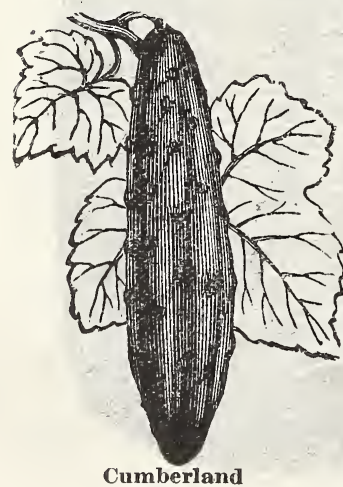
lkt., 5c; oz., 10c; 1/4 lb., 35c; 1 lb., \$1.00.

Gherkin or Burr -Oval shaped, prickly; for pickling only:- Pkt., 5c; oz., 25c.

LIPIROVED EXTRA LONG GREEN.

An extra fine variety, grows very long, very proFor early and late crops, excellent for pickles, Rlkt., 5c; oz., 15c; 1/4 1b., 35c; 1 1b., \$1.25.

NEW JAPANESE CLIMBING CUCUMBER.

Can be grown on trellises, fences, etc, saving valuable space in small gardens. It is very prolific, about ten inches long, thick and fine flavor. Pkt., 10c; oz. 25c; 1/1 1b., 75c; 1 lb., \$2.00.

\section{CUMBERLAND PICKLING.}

See illustration. A new sort that is quite popular as a pickle cucumber, long, light greven and very prolific, and a good variety for slicing. Cumberland

$20 \mathrm{c} ; 1 / 4$ lb., 65e; 1 lb., $\$ 2.00$, postpaid.

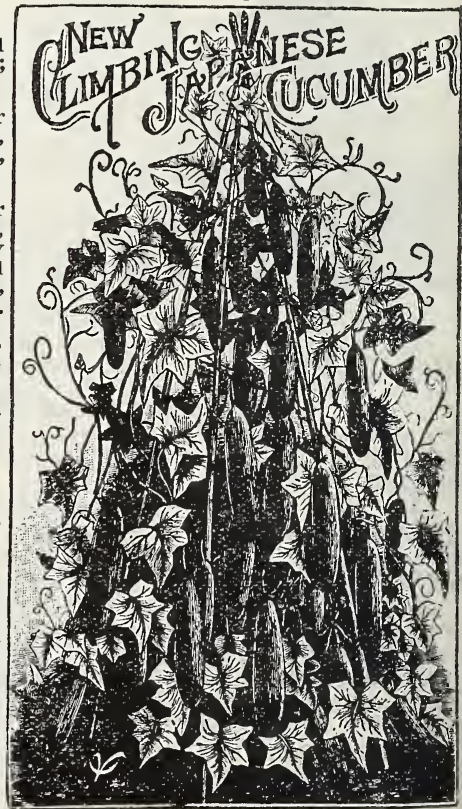


A R CHIA , SEED STORE, SEDALIA, MISSOURI

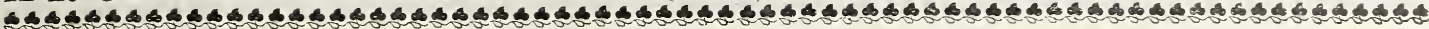

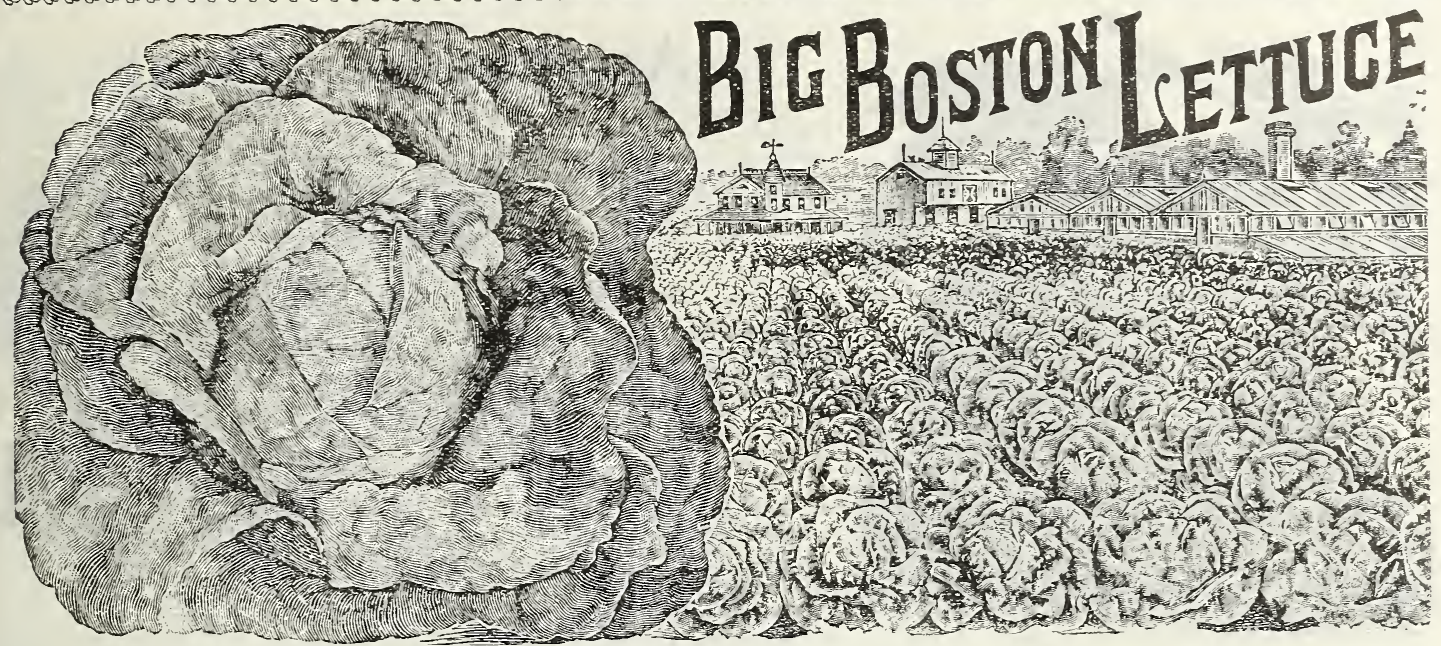

Archias' Extra Selected Big Boston Lettuce (45 Days)

The most popular variety for every purpose on the market. Gives equally good results under glass or in the open. Of the head types it is easily the leader. Leaves are light greell and very tender. Our strain of
this variety is unsurpassed. Large Pkt., 10c; oz., 20c; $\mathbf{1} / \mathbf{4}$ lb., 60c; 1 b., $\$ 2.00$.

\section{May King}

This remarkable variety has proven itself capable of satisfying the most exacting requirements that could be made on an early outdoor lettuce. It is not easily afproduces, eren in poor soil, splendid globular heads very produces, even in poor soll, splendid globular theads very $\$ 1.75$.

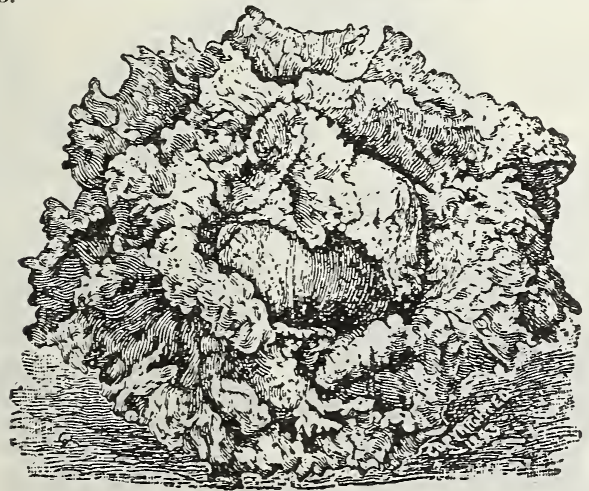

Large Hanson

\section{Improved Large Hanson}

Grows to large size, and is uniformly sure heading. Heads very solid, beautifully blanched; crisp, mild and tender. One of the finest varieties to grow for market during the summer months. Our stock is unexcelled. Pkt., 5c; oz., 15c; $1 / 1$ lb., 40c; $1 / 2$ 1b., 70c; 1 1b., \$1.25,

\section{Prize Head or Satisfaction}

Very tender leaves of dark reddish brown color vartegated with dark green. Heads large and of good flavor. We sell more of this than any other brown-leaved va-
riety. Always satisfactory. Ikt., 5c; oz., 15c; 1/4 1b., riety. Always

\section{Black Seeded Simpson}

Archias' Selected Stock-The standard sort for early spring planting and growing under glass. Very popular among market gardeners, and fine for home market. leaves are large, thin, exceedingly tender and of curly good quality. Pkt., 5c; oz., 15c; 1/4 1b., 45c; 1 lb., \$1.25.

\section{Archias' New Iceberg}

A Beautiful Lettuce, Worthy of Universal CultivationLarge, curly leaves of bright, li g h ally solid because of the natural tendency of the large, strons leaves to turn in thorough blanching. Q u a lity perfect. Pkt., 10c; oz., 20c; si.50.

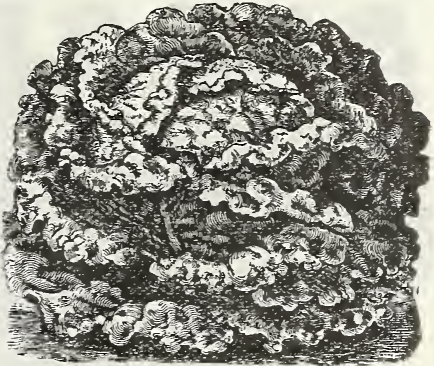

Archias' New Iceberg

\section{Mammoth Black Seeded Butter}

strain of large, smooth-leaved head lettuce, forming large, solid, cabbage-like heads of thick, brittle leaves oz., 15c; $1 / 1$ lb., 45c; $1 / 2$ lb., 75c; 1 lb., $\$ 1.25$.

\section{Tomhannock}

The Handsome Reddish Bronze Lettuce-This lettuce 作 within. Fdges of outer leavcs are a crisp and tender. Pkt., 10c; oz.,, 20c; 2 ozs., 35e; $1 / 4$ 1b., 75e; $1 / 2$ lb. $\$ 1.00 ; 1$ ib., \$1.75.

\section{Grand Rapids Forcing}

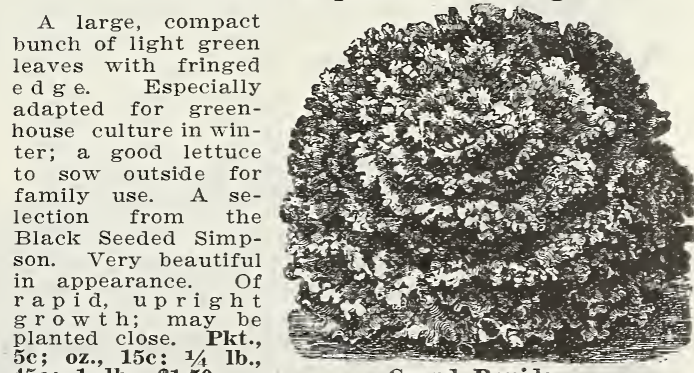

Grand Rapids

\section{Early Curled Silesia}

Does not head, but forms a compact mass of curly leaves of yellowish green. It matures early; generally 5c; oz., 15c; 1/4 lb., 40c; 1 lb., $\$ 1.00$

\section{OTHER GOOD LETTUCE}

CALIFORNIA CREAM BUTTER. TENNIS BALL PARIS WHITE COS GOLDEN STONEHEAD, WHTE SUMNER CABBAGE. EITHER OF ABOVE: Pkt, 5c; oz., 10c; $1 / 4$ 1b., 25c; 1 lb., 75c, postpaid. 


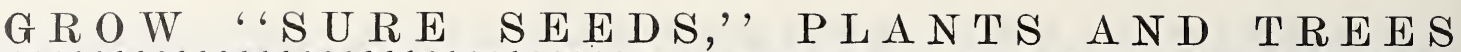

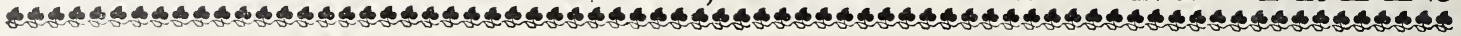

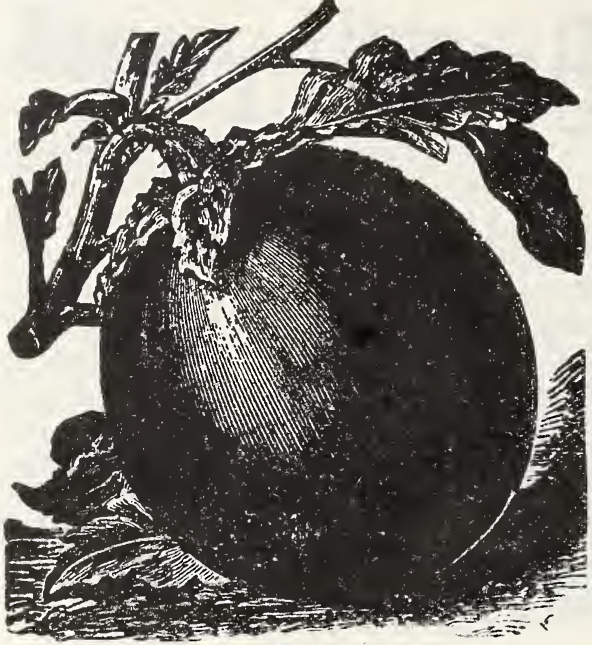

Improved N. Y. Purple

\section{Archias' Egg Plant}

Improved New York, Large Purple-Our strain of this standard variety is of the very finest type, absolutely spineless. The plants grow low, stalky and branching. They bear early and almost continuously. The fruits are large, smooth, and have a rich satiny this variety. Plkt., 10c; oz., 35c; 1/4 1b., \$1.25.

\section{Endive}

Green Curled-Crisp, dark green leaves; the hardiest. Oz., 15c; $1 / 4$ 1b., 50c.

White Curled-Leaves pale green. Oz., 10c; $1 / 4$ lb., 35e.

\section{Garlic}

Selected Bavarian-This is a particularly fine strain garlic. It is larger and more even than ordinary garlic, keeps longer and is snowy white. Lb., 50c; 3

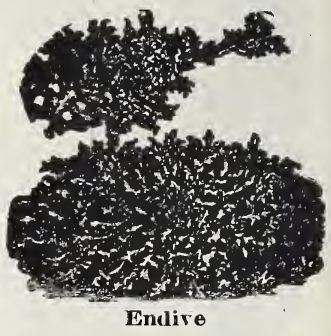

Horseradish Roots-See plants and Roots.

Martynia-Pods used for pickles. The plant is also quite ornamental. Do not plant seed too early. Pkt., 10c.

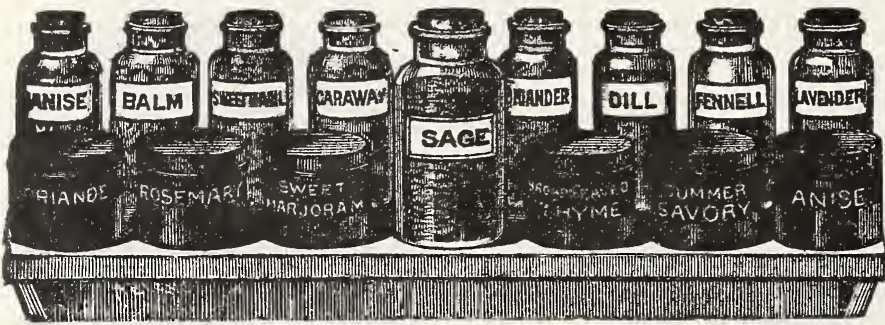

\section{Herbs, Each 10 Cents Per Package}

Every kitchen should have a few herbs. They are easily grown and are always pleasant and desirable for flavoring, perfuming and medlcal purposes. All varieties marked with $(*)$ are perennial.

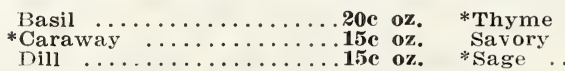

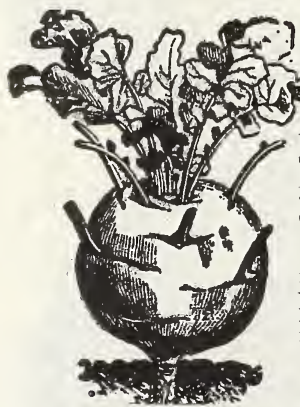

\section{Kohl-Rabi}

Kohl-Rabi is grown for its turnip shaped bulb, which is formed above ground. The bulb should be used while young and tender. Set plants eight inches apart.

Earliest White Vienna-Greenish-white outside, with clear. white flesh within. Smooth, short leaf; good for forcing: fine quality. Pkt., 10c; oz., 25e; $1 / 4$ lb., ; 1 lb., \$2.00.

Earliest Purple Vienna-Same In every respect as earliest White Vienna, except in the outside color. Plst., 10c; oz., 25c; 1/4 lb., 75c; 1 lb., \$2.25.

\section{Kale or Borecole}

Dwarf German Green-Sow in autumn for sprouts of green; desirable in every garden. Height, 8 inches. Pkt., 10c; 0z., 15c; 1/4 lb., $35 \mathrm{c} ; \mathrm{i}$ 1b., $\$ 1.00$.

Tall Green Scotch-Oz., 15c; 1/4 lb., 45c; 1 lb., \$1.00.

\section{Leek}

Large London, or Flag-A hardy specimen of onion. Sow in drills or broadcast. When 6 inches high transplant into rows 1 foot apart, 4 inches deep, 6 inches apart in rows. Mostly us

\section{Sage Plants}

Holt's Mammoth-The largest variety grown. This variety does not bloom, therefore does not make seed. Plants are strong. Each, 15c; 2 for 25c; 5 for 55c; doz., \$1.25, postpaid.

\section{Mustard}

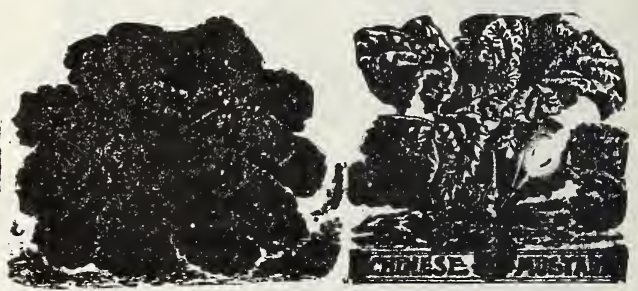

Make repeated sowings in shallow drills a foot apart; of easy cultivation. Cut when not over 3 inches high. White-Best for salad.

los., by express, $\$ 2.00$. Brown or Black - St

4 lo., 30e, 1 lib., leaves very curly. Oz,, 15c; $1 / 4$ lb., 50c.

\section{Mushroom Spawn-The Big Paying Crop}

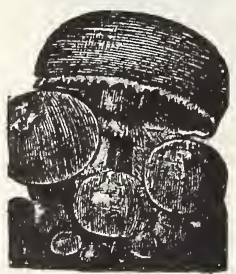

Large White Wushrooms may easily be crown where a fresh supply of horse manure and a ellar or tight shed are available, and where a temperature of 50 to 75 degrees can be maintained.

American Pure Culture Spawn-Produced by a new method from virgin spores. Pure Culture Spawn is far superior to spawn that is imported, and when once used no other is wanted. The results show it is by far the cheaper. A brick weighs 1 1-3 pounds, and is sufficient for a bed $2 \times 4$ feet. We receive fresh spawn every few weelss direct from the best makers. Culture direc-
tions free with every order. One brick, 35c; 3 bricks (4 1bs.), \$1.00, postpaid. Not prepaid: 1 brick, 30c; 3 bricks, 75c; 10 bricks, \$2.00. Special prices on larger quantities.

Book on Mushroom Culture Tells how to prepare beds, plant spawn care, Gath-

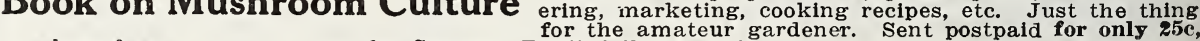
or given free with any order for Spawn. Don't fail to get it. 


\section{G R O W "S URE SE E D S,' P L A N T A N D T R E S}

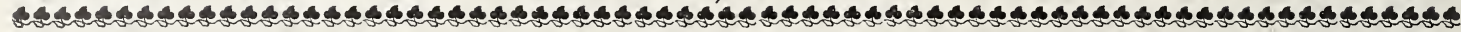

\section{Archias' Watermelons-Continued}

Fordhook Early-An extra early Melon of large size. Seeds are white, the flesh is bright red and very sweet. Oz., 10c; 1/4 ib., 35c; 1 lb., 85c; 3 lbs., $\$ 2.00$ postpaid.

Archias' Dark Icing-An extra fine Melon; solid,

bright red and of exshipping Melons. Oz., 10c; 1/4 Ib., 35c; 1 Ib., 85c; 5 Ibs., $\$ 3.00$, postpaid.

Halbert Honey-One of the finest Watermelons for home garden: uniform in color and shape, being free from any tendency to "neck." Skin dark, glossy green; flesh beautiful crimson. Oz., $15 \mathrm{c} ; 1 / 4$ Ib., $45 \mathrm{c} ; 1 \mathrm{lb} \$ 1.00 ; 3$ ibs., $\$ 2.75$, postpaid

OTHER GOOD VARIETIES AT OZ. 10c; $1 / 4$ LB. $35 c ; 1$ LB. $85 c$; 5 LBS. $\$ 3.50$, POSTPAID.

Phinney's Improved Early-First to ripen; good size, productive, oblong, flesh deep red. A first-class market Melon.

Black Diamond-Mammoth size, weighing 75 to 100 pounds; dark green, almost black.

Georgia Rattlesnake-Long, light rind and striped; flesh red; seeds light.

Impraved Long Dixie-Longer than Kolb's Gem; dark green; striped; the flesh is of an intense deep, bright scarlet: very sweet.

Peerless-A very popular variety; flesh solid, bright red; sure

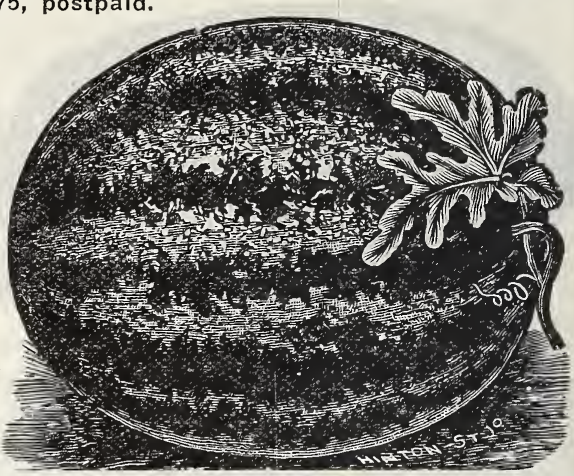

Kolb's Gem
Gray Monarch, or Long White Icing-Mottled color; flesh bright crimson; a fine shipper.

Seminole-One of the best large, long. Melons. Early enormously productive, and of most delicious flavor.

Jones' Jumbo-Skin solid green; flesh bright red; attaining the weight of 80 pounds.

\section{Archias' Delicious Muskmelons}

CULTURE-Late in the spring drop 20 seeds in hills 5 feet apart. When up large enough thin out to three or four plants: work the same as Watermelons. The following list contains none but choice varieties. Slug-Shot Kills Melon Bugs. (See page 92).

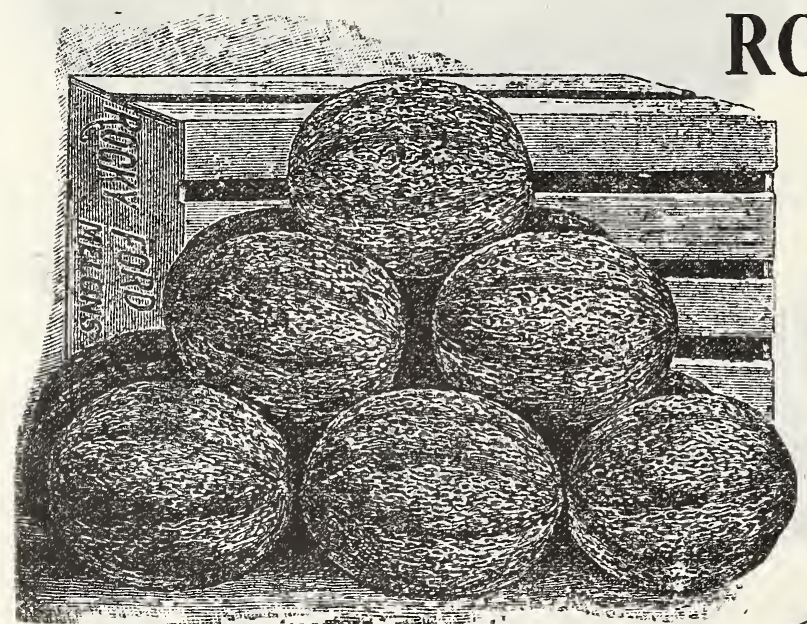
(

Livingston's Nabob-Shape of Kolb's Gem: mottled green rind; red flesh, and of excellent quality.

Preserving Citron-Red seed. For sweet meats and preserves; flesh "solid. 


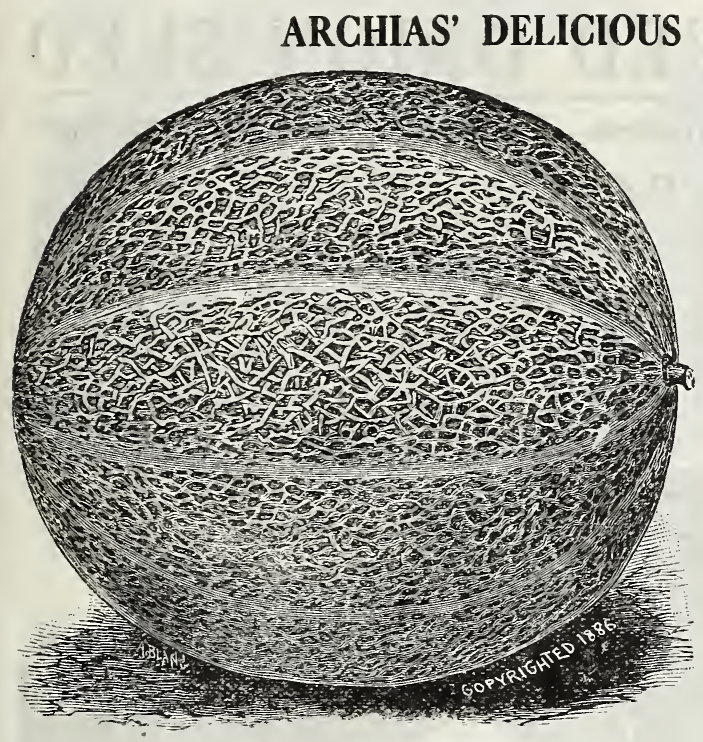

Archias' Champion Market.

\section{Livingston's Tip Top}

The melons are round in form, well ribbed, with light green skin, which becomes slightly netted when ripening, and average 7 inches in diameter. The flesh is quite thick, bright salmon in color and of luscious flavor. Pkt., 10c; oz., 15c; $1 / 4$ lb., 40c; $1 \mathrm{lb} ., \$ 1.50$.

\section{Montreal Market}

Nearly round, very showy, flat at the poles, skin netted and green; grows very large, often reaching $20 \mathrm{lbs}$; flesh thick, of good flavor, very sweet. Pkt. $5 c$; oz., $10 \mathrm{c} ; \mathrm{l} / 4 \mathrm{lb} ., 35 ; 1 \mathrm{lb} . \$ 1.00$.

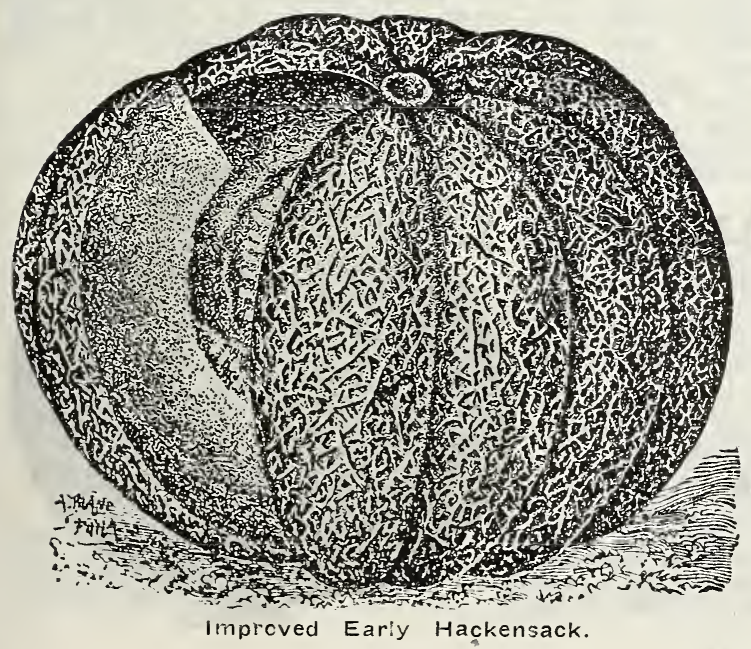

\section{Archias' Champion Market}

A well known sort. The Melons grow very uniform in size and shape, ranging from 4 to $5 \frac{1}{2}$ lbs. each; light green and rich, sweet flavor; heavy netting and handsome appearance. Pkt., 10c; oz., 15c; 1/4 lb. 45c; $1 \mathrm{lb} . \$ 1.25$.

\section{Improved Early Hackensack}

This valuable variety is ready for the market fully 10 days ahead of the well known Hackensack; weigh 5 to 10 lbs. each. Pkt., 5c; oz., 10c; 1/4 lb., 35c; $1 \mathrm{lb}$, $\$ 1.00$

\section{Burpee's Netted Gem}

This very early Cantaloupe Melon is one of the most delicious in the whole list. Small and round in shape. Firm, green flesh. Sweet and luscious clear to the rind. Pkt., 5c; oz., 15c; $1 / 4$ lb., 35c; $1 / 2 \mathrm{lb} ., 55 c ; 1 \mathrm{lb}$, $\$ 1.00$.

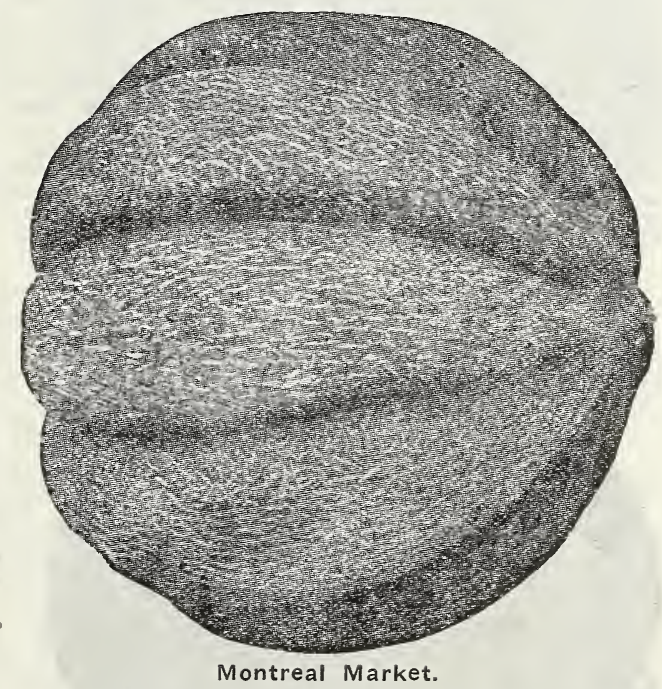

\section{Osage or Miller's Cream}

The flesh is rich salmon color, very sweet and melting in quality; very thick, almost solid. Oz., $10 \mathrm{c} ; \mathrm{l} / 4 \mathrm{lb} ., 35 \mathrm{c} ; 1 \mathrm{lb} ., \$ 1.00$.

\section{Banana}

Flesh quite thick and of a rich salmon color, growing from 2 to 3 feet in length; is early. Pkt., 10c; oz., 25c; $1 / 4$ lb., 75 c; 1 lb., $\$ 2.25$.

A!so the following good Melons at, Pkt. $5 \mathrm{c}$; oz., 10c; $1 / 4$ lb., 35c; $1 / 2$ lb., 50c; 1 lb., 90c. CANNON BALL, NUTMEG, TURKS, CAP, PAUL ROSE, DELMONICO, BAY VIEW, LONG YELLOW CANTELOUPE, LAND. RETH'S CITRON, WINTER PINEAPPLE. 
GROW "SURE SEEDS," PLA N T A N D TREE

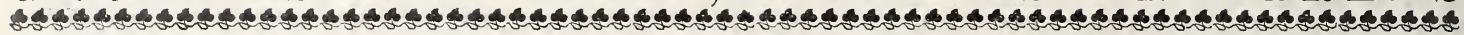
ARCHIAS' PEDIGREED ONION SEED Celebrated for Purity, Quality, Size and Productiveness-Money Makers and Prize Winners

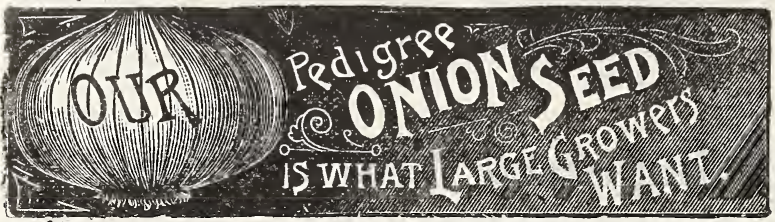

Culture Onion seed should be sown as soon the weather is cold, just so the soil works up well. This gives the onion a good start and ahead of weeds and before dry weather sets in. After thor. oughly pulverizing the soil, sow 4 to $5 \mathrm{lbs}$. to the acre, in drills 1 foot apart and about $1 / 4$ inch deep. When 4 inches high thin out to stand 3 to 4 inches apart in the rows, keeping them well hoed and free from weeds. Onions delight in rich, deep, sandy loam and succeed well if grown for a sucing prevents blight.

\section{MAMMOTHW PRIZE TAKER}

This new and handsome variety is a splendid type of the celebrated Spanish fancy onions, which are annually imported into the United States from Spain and sold in our large cities at from 25 to 50 cents each, and even higher.

The American-Grown Prize-Taker Onion is a very handsome Onion and should be almost perfectly globular in form, as shown in the illustration, with thin skin of bright straw color. It is of immense size, measuring from 12 to 18 inches in tircumference, while under special cultivation specimen bulbs have been raised to weigh from three to five pounds each. It ripens up hard and fine and presents the handsomest possible appearance; the flesh is pure white, fine grained, mild and delicate in flavor; excellent for fall and early winter, Per pkt., 10c; oz., 20c; 1/4 lb., 75c; 1 lb., $\$ 2.50$, postpaid.
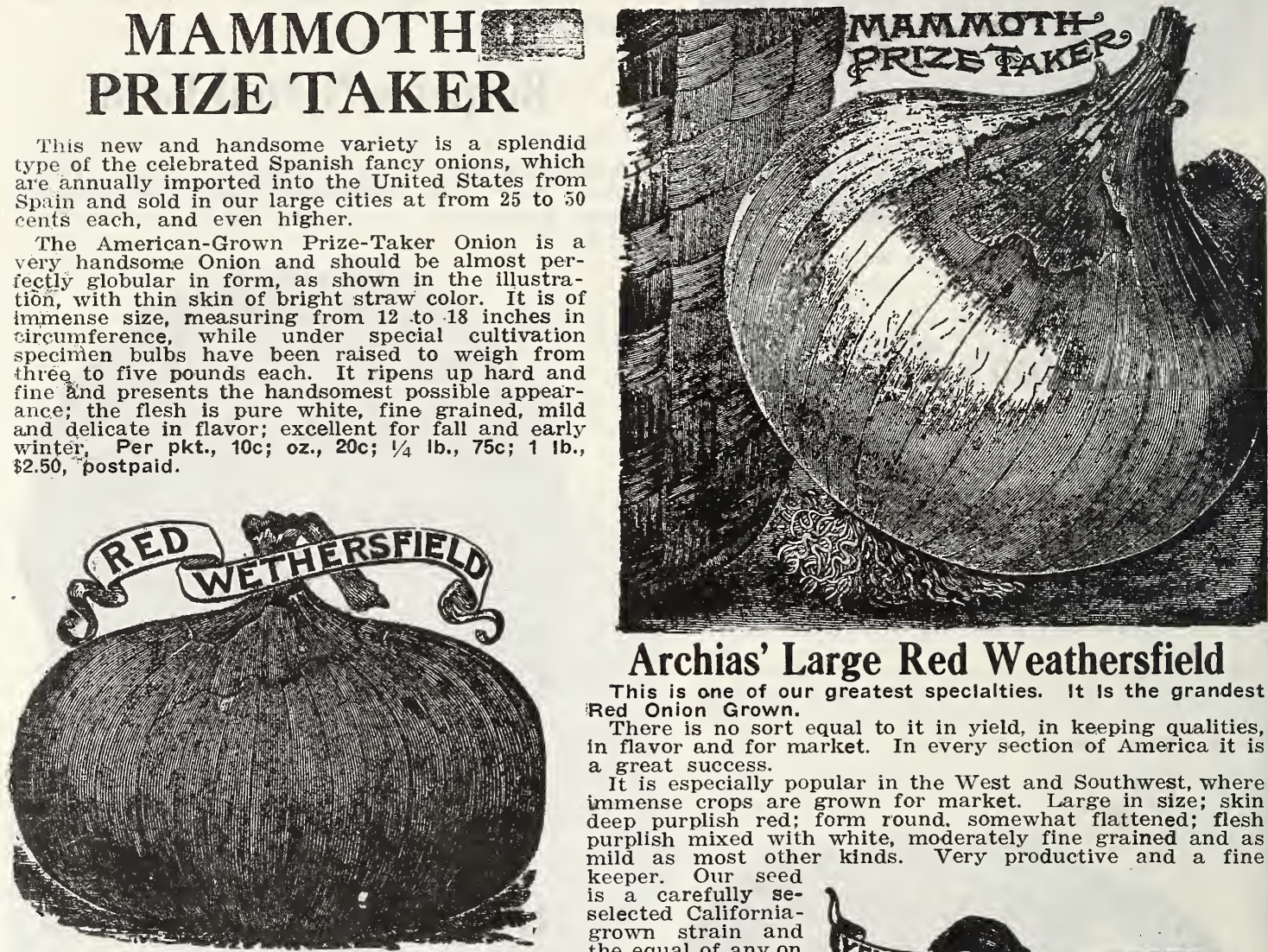

Archias' Large Red Weathersfield

This is one of our greatest speclalties. It is the grandest Red Onion Grown.

There is no sort equal to it in yield, in keeping qualities, in flavor and for market. In every section of America it is a great success.

It is especially popular in the West and Southwest, where immense crops are grown for market. Large in size; skin deep purplish red; form round. somewhat flattened; flesh purplish mixed with white, moderately fine grained and as mild as most other kinds. Very productive and a fine keeper. Our seed is a carefully seselected Californiagrown strain and the equal of any on the market today. Our customers sweep every state
premium. Pkt., 5c; oz., 20c; 1/4 Ib., $75 \mathrm{c} ; 1$ lb., $\$ 2.50$.

\section{SELEGT YELLOW GLOBE DANVERS}

In many parts of the country the Danvers Yellow Globe is the favorite, and If first-class seed, such as we offer, was always furnished by dealers this sort would be liked' everywhere. Our choice seed produces the true globe-shaped Danver's. Avoid buying cheap California grown Danvers yellow. Our stock is grown from the choicest selected bulbs and sure to give satisfaction. Pkt., 5c; oz., 20c; 1/4 Ib., 75c; 1 ib.) $\$ 1.35$.

Extra Early Barletta-The very earliest Onion in cultivation, pure white, very mild and delicate flavor; for table use and pickling it is most valuable. Pkt., 5c; oz., 25c; 1/4 lb., 85c; 1 ib., $\$ 3.00$.

\section{OHIO YELLOW GLOBE}

A favorite variety among the Ohio Onion growers of bright straw color; an excellent keeper and a good yielder. It is reported that 800 buishels of Ohio Yellow Globe Onions have been grown on a single acre of good land. It is especially recommended for heavy muck land on account of its early maturing qualities. Pkt., 10c; oz., 20c; 1/4 lb., $85 \mathrm{c}$ ? $\mathrm{lb}$., $\$ 3.00$.

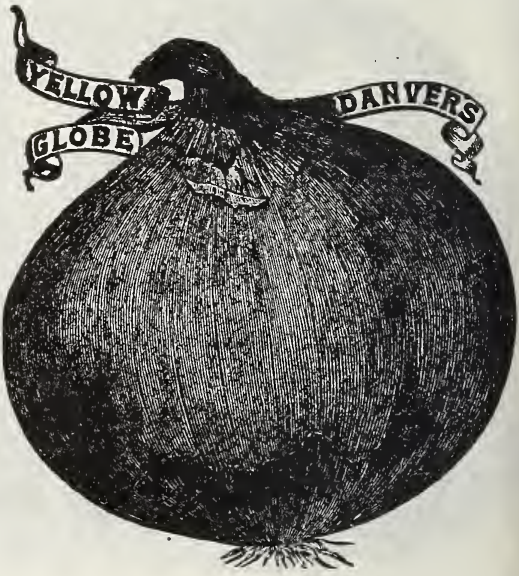


A R CHIA ' SEED STORE, SEDA LIA, MISSOURI

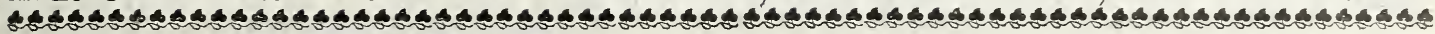

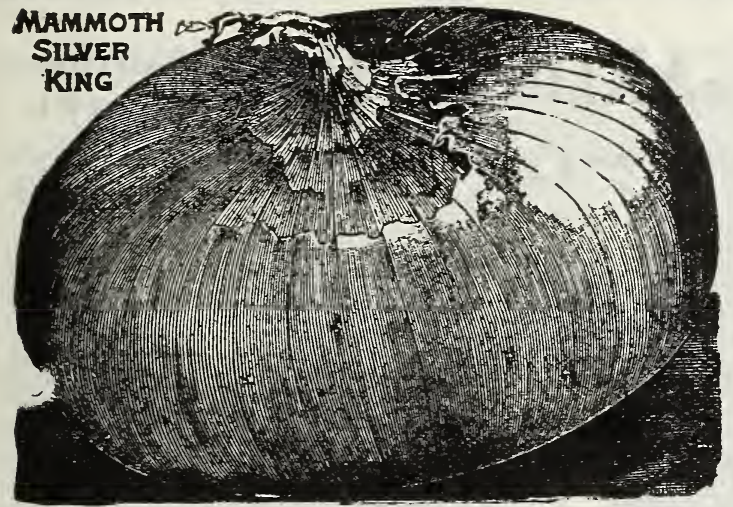

Red Globe Wethersfield

A most attractive variety; beautiful shape and of a deep, rich red color. Pkt., 10c; oz., 45c; $1 / 4$ 1b., \$1.35; 1 1b., \$5.00.

\section{Southport Large Red Globe}

This is a very handsome variety. Vatures quite early, grows to a large size, skin deep red, flesh fine grained, mild and tender. Pkt., 10c; oz., 45c; 1/4 lb., \$1.35; 1 ib., \$5.00.

\section{Silver Skin or White Portugal}

The Standard White Onion for Market and Family Use. Flavor mild and pleasant; skin silver white, of handsome ap pearance, highly esteemed for pickling when young, also for market and early winter. This is the variety from which white Onion Sets are grown. It will please you immensely for any purpose. Buy your seeds from first hands. Our own growth choicest high grade pedigree stock seed. Plit., 5c; oz., 25c; $1 / 4$ choicest high grade 1 ib., $\$ 3.00$.

\section{Red Bermuda Onion}

The original variety. Similar in form and early ripening to the White Bermuda; very flat, and of a light pink color. The flesl1 is white, slightly suffused with pink. Tenneriffe grown seed. Pkt., 10c; oz., 35c; $1 / 4$ lb., \$1.25; 1 lb., \$1.50.

\section{White Bermuda Onion}

This valuable Onion is especially adapted to the Southern States, the most profitable of all varieties of Onions for the grower. Ease of cultivation, large size and mildness of flavor make it the most valuable of this type. We offer seed direct from the Canary Isles, the home of the Bermuda Onion. Pkt., 10c; oz., 35c; 1/4 lb., \$1.25; 1 lb., \$4.50.

\section{Archias' Hand Sorted Select Onion Sets}

Early green Onions are much earlier obtained by setting out sets than by sowing seed; some of the latter, how ever, should be sown to follow the crop grown from the Onion Sets. Plant both Onion Sets and Seed as soon as the ground is warm and dry in the spring.

to market changes. It is impossible for us to make fixed prices. on large or small quantities will be given on application at any time. We handle Onion Sets in large quantities.

YELLOW BOTTOM ONION SETS

WHTE BOTTOM ONION SETS.

RED BOTTOM ONION

RED TOP ONION SETS bushel.

WINTER TOPS prices in quantities of 1 bushel or over.

Special rates on large quantities of Onion Sets on application.

5c per qt. or 15c per gal. for postage if ordered sent by mail. Bushel,

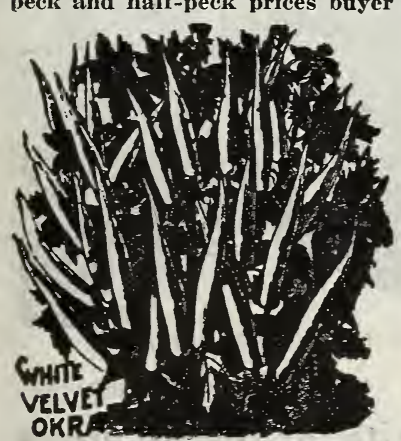

In high esteem for soups and stews. fashionable Southern vegetable stews. A growth at the North. An annual. The pods are used when young and tender. feet apart, -Sow in May and June after the ground is warm, in drills three of row.

KLECKLEY'S FAVORITE-The pods average 6 inches in length, by $1^{1 / 4}$ inches in diameter at the bottom, carrying the thickness well throughout the length. Plant grows $21 / 2$ to 3 feet in height; the

PERIKIN, IMPROVED GIANT GREEN POD-A new Okra, esteemed by canners and market gardeners. It is a great improvement on the old green podded sorts. Large, handsome green pod. Fine quality, very productive;

5 feet tall. Pkt., 5c; oz., 10c; 1/, lb., 25c; 1 lb., 75c.

WHITE VEivET-Pods are round and smooth, while in other sorts the pods are ridged or square edged. Superior flavor and tenderness. It is very

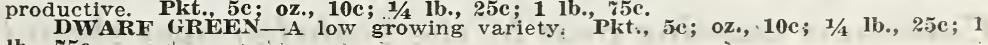
1b., 75c.

\section{Okra or Gumbo}




\section{ARCHIAS' SELECT GARDEN PEAS Northern}

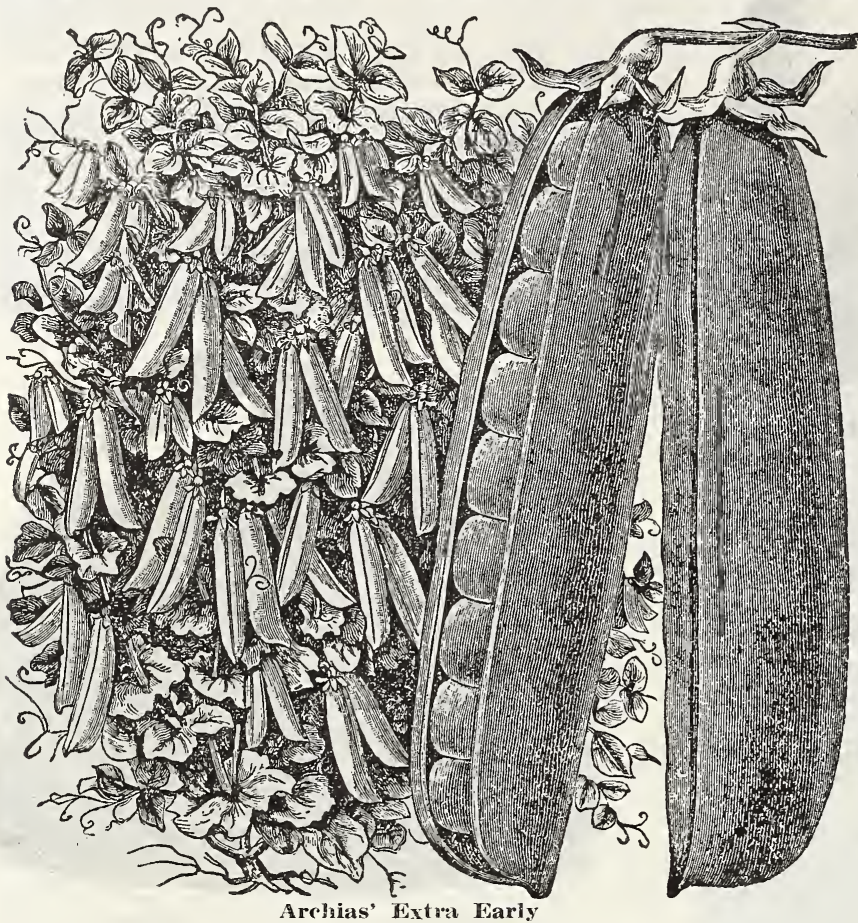

UR peas are Northern grown. Thery are the earliest, hardiest and most productive. peas. Peas belong in three groups. Garden, field and edible podded. Garden peas are smooth or wrinkled. The smooth are earlier and most hardy. The wrinkled are sweetest. Field peas are of high value in stock feeding and green manuring. Edible podded peas are growing in favor.

CULTURE-Sow in earliest spring and make successional plantings every ten days until July 1. In the latter part of August sow early peas for an autumn crop. Drill 1 to 2 inches deep in rows $2 \frac{1 / 2}{2}$ to 4 feet apart. In the field use no sticks. In garden culture sow in double rows 10 inches apart, and use supports for the tall growing varieties. One pint to 75 feet of

Canes for sticking peas, beans and other vine crops, $\$ 1.00$ per 100 .

\section{Archias' Extra Early}

As to earliness, uniformity in ripening and productiveness this pea leads them all, and is the production of several years of careful selection. It ripens in about 40 days, grows about 18 inches high, pods well filled and of good quality, the full, round, dark green pods are produced in wonderful profusion. Practically all the pods can be gathered at one or two pickings, and are well fitted for shipping long distances. It is so improved over all other strains that it fully sustains our claim of being the BEST of the EXTRA EARLIEST. It is the best for the market gardener, best for home gardens, best for shipping, best for every purpose. Pkt., 10c; pt., 30c; qt., 50c; 4 qts., \$1.50.

\section{Archias' Early Surprise Peas \\ One of the Earliest Wrinkled Varieties}

Gardeners who have been looking for a choice wrinkled pea which would come into market as soon as the early smooth kinds will find it a surprise, for, though as early as the earliest hard sorts, it has the delicious sweetness which belongs only to wrinkled peas. Vines about 24 inches sale. It is unsurpassed in quality. Pkt., 10c; pt., 35c; qt., 60c; 4 qts., \$2.00.

\section{Alaska Extra Early}

The earliest blue pea; very uniform in growth It can be carried long distances without losing color; height 2 feet. Pkt., 10e; pt., 25c; qt., 50c; 4 qts., \$1.50.

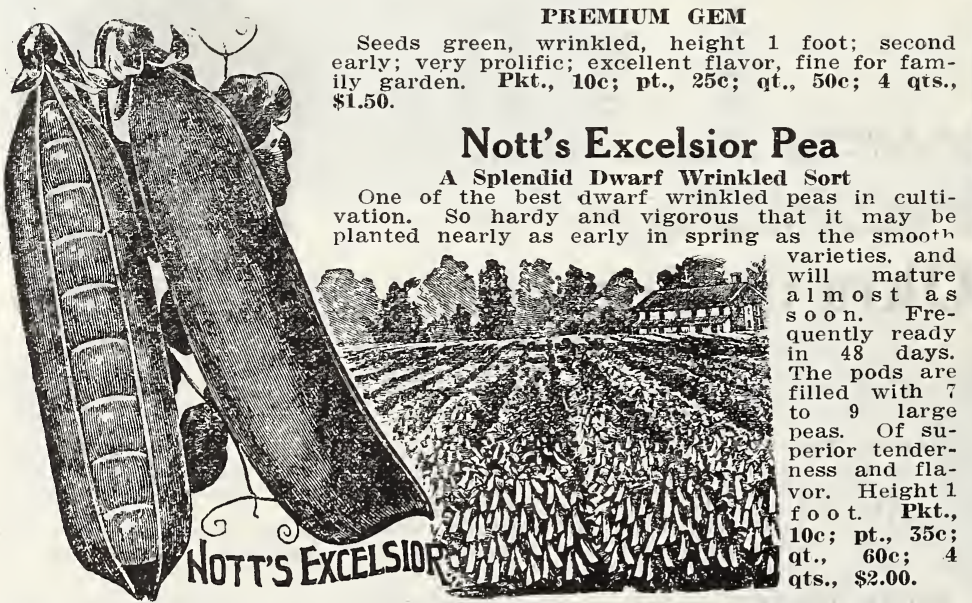

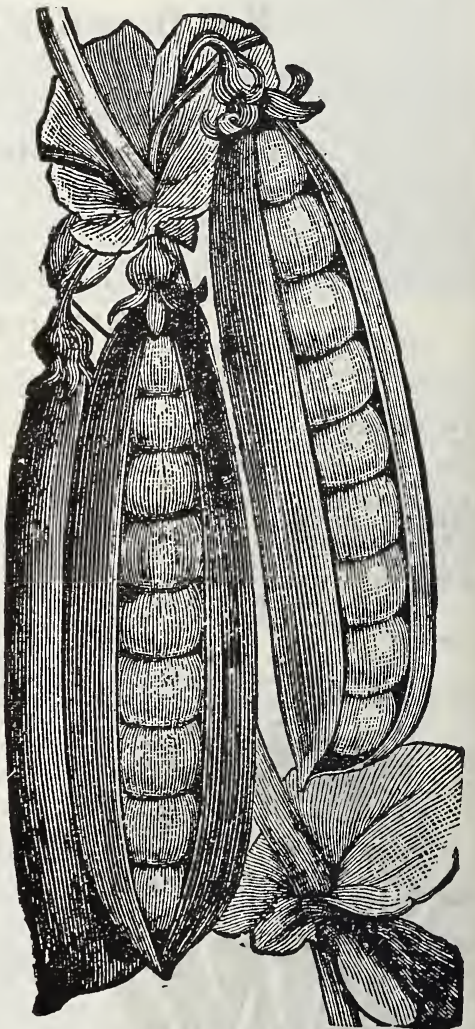

Archias' Early Surprise.

FOR A LARGER AND BETTER YIELD, SEED SHOULD BE INOCULATED WITH FARMOGERM. (See page 36). 
G ROW "'S U R E S E E D S," P L A T S A N D T R E S

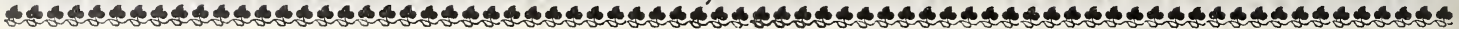
ARCHIAS' NORTHERN GROWN SEED POTATOES

Are Standard with the critical Potato Growers throughout the United States. For smoothness, freedom from disease or roughness and trueness to type we have been unable to find ANITHERE stork that will average with ours.

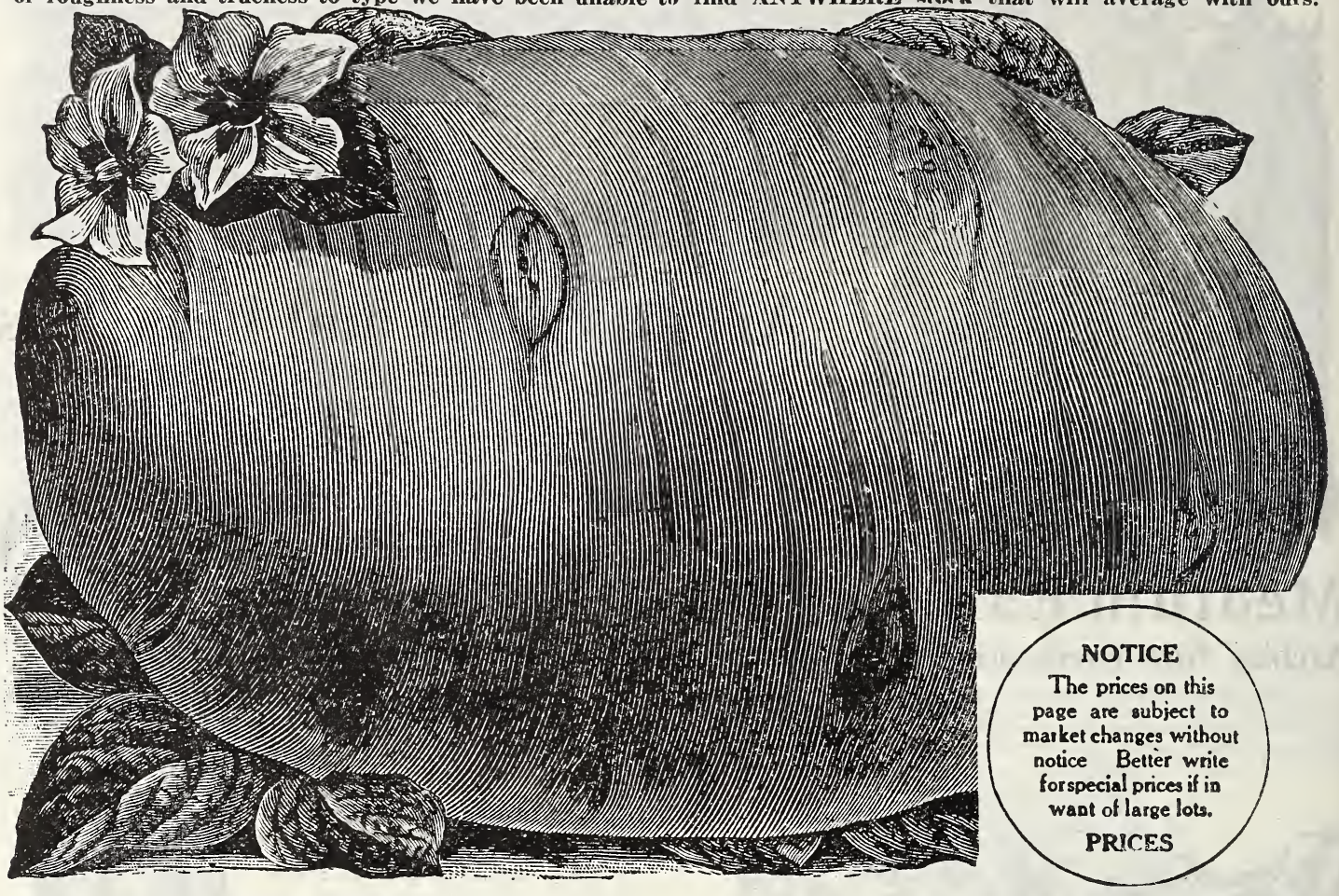

\section{Archias' New White Early Six Weeks}

A grand, new, extra early white potato of excellent quality, maturing in six weeks from planting; extremely prolific, and on account of its white skin, places it at the head of all others. The potato for market gardeners, trucker and family garden.

Archias' New White Early Six Weeks is a sport from the well-known Red Early Six Weeks and is superior to its parent in every way. The great demand in every mar ket for a white potato places this one in the front rank. Superior in color, quality and productiveness, and commands the top price on the market. It has a great yield record. We never have enough Archias' New White Early Six Weeks to meet the demand for this grand early potato, so will advise our patrons to order early. Prices pk., 60c; pk., $\$ 1.00$; 1/2 bu., \$1.75; 1 bu., $\$ 3.25$; 2 bu., $\$ 6.25$.

NOTE-Customers can order $1 / 2$ bushels at bushel rates.

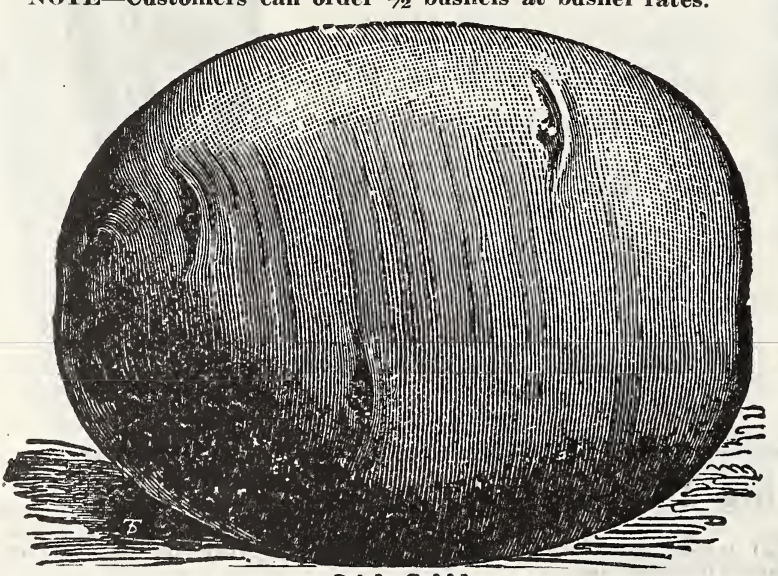

Irish Cobbler

\section{CHICAGO MARKET}

A Grand Market Potato

TRULY A WONDERFUL POTATO

Handsome, Blight Proof Variety. Very Heavy Yielder,

A new Extra Early variety of great promise. Makes An extremely quick growth and considering its extra earliness is a wonderfully heavy yielder. Is of very handsome appearance with pinkish tinged skin and white flesh. Farlier than the Ohio and a much better and more profitable variety. Very popular among Chicago $1 / 2$ bu., $\$ 1.60 ; 1$ bu., $\$ 3.00 ; 2$ bu., $\$ 6.00$.

\section{SEED POTATOES BY MAIL}

For those who desire to test the merits of any of these varieties of potatoes, we furnish whole tubers by mail at 25c per lb., or 3 lbs. for $55 \mathrm{c}$.

\section{Irish Cobbler Potato}

A comparatively new and very fine early variety extensively grown for market in some localities. The tubers are very handsome, almost round, averaging uniform in shape and size. Flesh white and of excellent quality skin cream and buff with whitish netting. This is a very reliable variety and heavy netting. This is a very reliable variety and heavy
cropper. (See cut). Price, pk., 90c; bu., \$3.25; 2 bu., cropper.

\section{Sir Walter Raleigh}

A seedling of Mr. Carmen's. Fields almost all marketable size potatoes. Exceedingly fine grained and white fleshed, equaling the Snowflake. $1 / 2$ pk., 40e; pk.. 85c; 1 bu., $\$ 3.00$; 2 bu., $\$ 5.75$.

Burbank, a Standard Late Variety

It is of good size, of fine form and an excellent yielder. The flesh is white, very mealy and of fine flavor and quality. This variety is well adapted to heavy soils. Pk., 85c; bu., \$3.00; 2 bu., \$5.75.

\section{DATE OF SHIPMENT}

POTATOES will be shipped at any date ordered during the winter, but at your own risk. Where no special instructions are given to the contrary, we will hold same until in our judgment there will be no danger from freezing, and then ship promptly. 
A R CHIA , SEED STORE, SEDALIA, MISSOURI

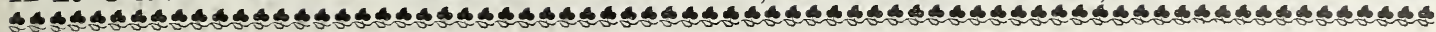

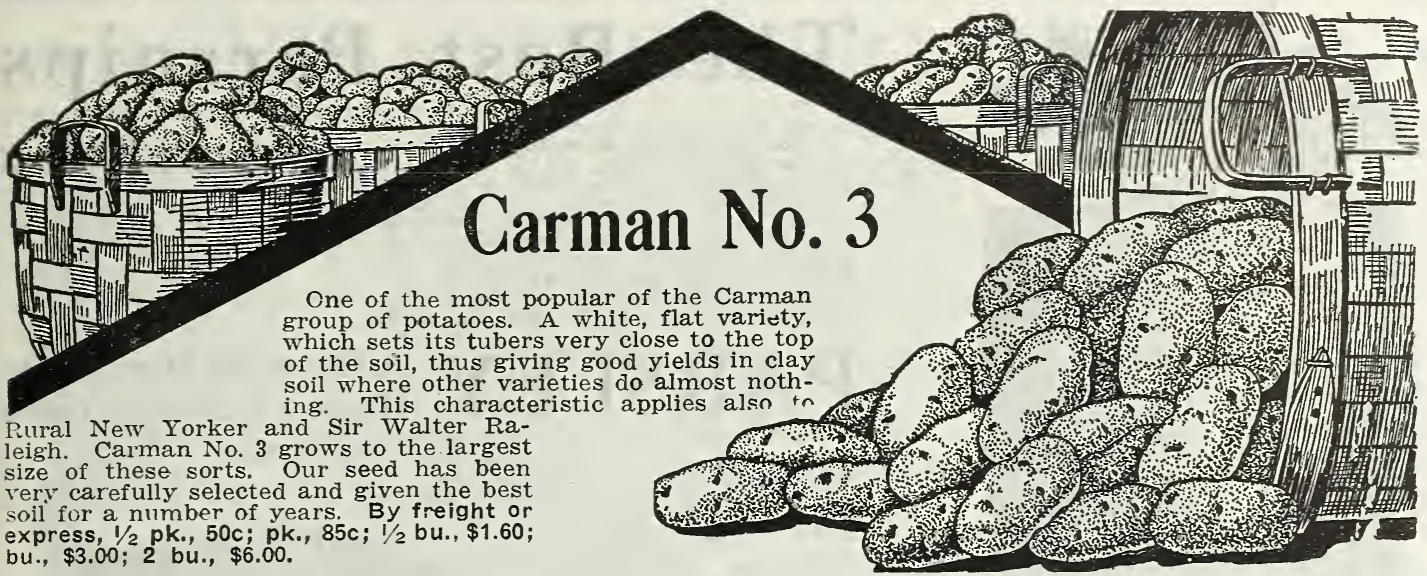

\section{Pure Early Rose}

The good old favorite which continues in great popularity. A prolific yielder, sure cropper and popular market potato. Every farmer and gardener knows the good Early Rose and nothing more needs to be said in its favor. The seed we offer is the purest and best that can be put on the market. Prices, postpaid, 1 lb., 25c; 3 lbs., 60c; by express or freight, not prepaid, 1 pk., $85 \mathrm{c} ; 1 / 2$ bu., $\$ 1.50 ; 1$ bu. (60 lbs.), $\$ 2.75 ; 2$ bu., $\$ 5.50 ; 5$ bu., $\$ 13.50$.

\section{Early Ohio}

leading early sort. Round, short and thick tubers, smooth and solid; cooks dry and mealy and matures very early. Pk., 85c; bu., 3,$10 ; 2$ bu., $\$ 6.00$.
BLISS TRIUMPH or IMPROVED BERMUDA

Matures a week in advance of the Early Rose. Tubers of medium size, round and uniform in shape, with but a very few small ones; eyes slightly depressed; color a beautiful light red. Pk., \$1.00; bu. $\$ 3.25 ; 2$ bu., $\$ 6.25$.

BANNER (Livingston's)

Tedium early A grand variety. very prolific Sure to please. Keeps well. 1/2 pk., 50c; 1 pk., $85 \mathrm{c}$; $1 / 2$ bu. $\$ 1.65 ; 1$ bu., $\$ 3.00 ; 2$ bu., $\$ 6.00$.

The following standard varietties, all Red Rlver, Northern Minnesota Seed. Pk., 85; bu., \$3.00; 2 bu. or over, at $\$ 2.90$.

White Elephant, Mammoth Pearl, Peeriess, White Star, Rural New Yorker No.2.

\title{
$50 \mathrm{New}$ Varieties of Potatoes
} Can Be Grown From One Package of Our Genuine HYBRIDIZED POTATO SEEDS. Every Seed Will Positively Bring a Different Variety.

THESE RARE and curious Seeds-from the Seed Balls -will produce white yellow, pink, red, blue, purple, variegated, and black Potatoes. Often 50 to 200 in a hill. of shapes, types and qualities innumerable. Early and late, strange freaks, etc.

\section{All Valuable New POTATOES} Are Produced From Just Such Seeds

One may make your fortune. Now is your time. Give your Boy a chance also to grow "Seedling" Potatoes. It is so easy. He may be the lucky one. The possibility of producing a new variety superior to all others-and more valuable than a gold mine-is fascinating in the extreme.

Order now. Secure Headquarters Stock while you can. Please show this to your friends.

Package, with Full Directions, 15c; 4 for 50c; 10 for $\$ 1$.
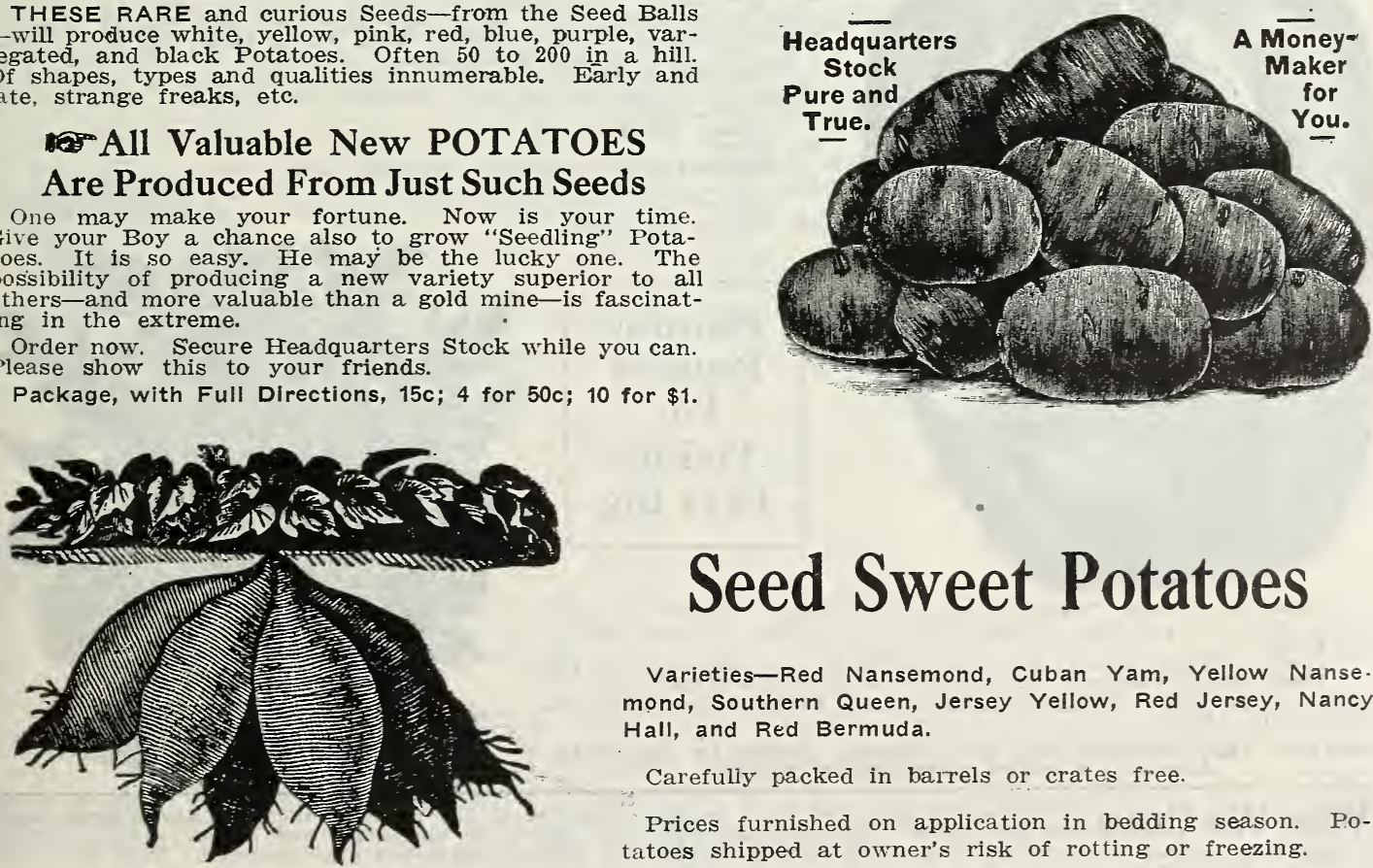

\section{Seed Sweet Potatoes}

\author{
Varieties-Red Nansemond, Cuban Yam, Yellow Nanse \\ mond, Southern Queen, Jersey Yellow, Red Jersey, Nancy \\ Hall, and Red Bermuda. \\ Carefully packed in barrels or crates free.
}

Prices furnished on application in bedding season. Potatoes shipped at owner's risk of rotting or freezing. 
GROW "S URE SEEDS," PLA N T A N D TREES

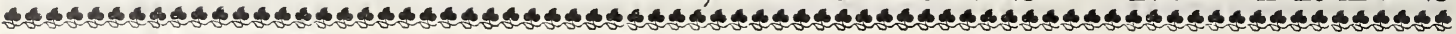
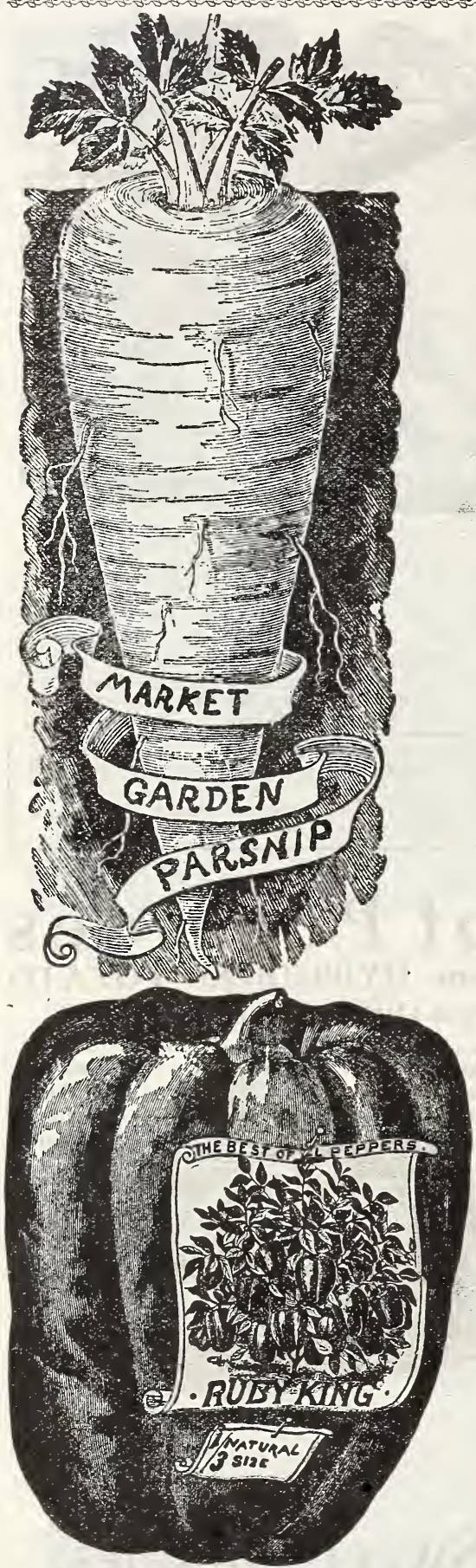

Monstrous Sweet Spanish-Large, red, early productive, mild flavor, fine for packing, stuffed and mixed. Pkt., 5c; oz., 35c; 1/4 lb., \$1.25.

Cherry-Round, small, good bearer, fine for fancy pickles. Oz., 45c. Finest Mixed Peppers-A mixture of which you will find very desirable for pickling, mangoes, relishes, etc. Price, 5c per pkt.; oz., $35 \mathrm{c} ; 1 / 4$ 1b., $\$ 1.00$.

WE PAY THE POSTAGE ON ALL GARDEN SEEDS IN THIS CATALOGUE, EXCEPT OTHERWISE NOTED. seed to 150 feet of drill. April.

Champion Moss-Curied -A choice selected strain, beautifully c r im p e d,
curled leaves. $\mathrm{oz}_{\text {. }} 15 \mathrm{c}$; 1/4 1b., 50c.

for seasoning, excellent oz., 15c; 1/4 1b., 50c. decorating. Plkt., 5c; oz., 15c; 1/4 1b., 50c. paculed Curied-Compact; very curly and finePkt., 5c; oz., 15c; 1/4 1b., oz., 30c; 1/4 1b., \$1.00.

\section{Planting Peppers For Pickles Pays Big}

The Best Parsnips

Spade the soil deep and sow in shallow drills 15 inches apart early the spring in rich soil. Hoe often and deep.

Hollow Crown a a so long as those of the pulled. A very heavy cropper. Pkt., 5c; oz., 15c; 1/4 1b., 50c; 1b., \$1.50. tend Lrown, Long Smooth-(Abbott's Improved)-Smooth, large, tender and sugary; one of the best. Our stock is very fine. Pkt., 5c; Bloomdale-Half long, very productive; similar to Hollow Crown.

\section{PARSLEY A Flavoring Herb of the} PARSLEY Highest Culinary Value f CUTURE-Soak seed for several hours and sow in border of lame. Thin the rows or transplant to another bed. If to be carried will go through the winter with moderate protection. Use 1 ounce of

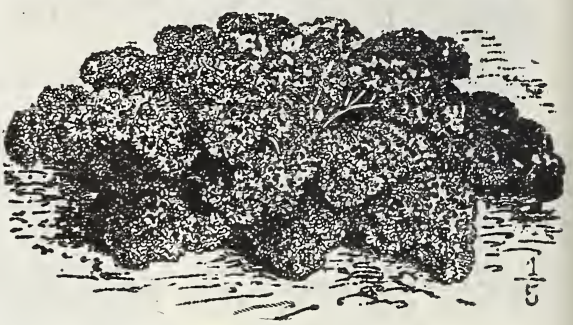

Double Curled Parsley

\section{The Finest Peppers} stuffed for pickling and in a variety of ways. When mangoes. der glass, like egg plant. The plants should be set $1 \frac{1 / 2}{2}$ feet apart in rows 2 to 3 feet apart. A warm, moist soil is best, with plenty of manure plowed under. An ounce of seed will produce 1,250 New Chinese Giant-A most romarkable pepper. Double the size of Ruby King. Immensely productive, extremely attractive and of market gardeners sweet as an apple; a profitable variety both for 1 oz., 50c; 2 ozs., 75c; 1/4 lb., \$2.50.

New Ruby King-Wonderful yielder, Peppers 3 to 4 inches in diameter, of mild flavor, very desirable for mangoes. Pkt., 5c; oz., lb. Golden Dawn-Large, yellow, prođiuctive、 Pkt., 5c; oz., 30c; 1/4

Celestial-Pods are borne upright; conical in shape, and vary in Cayenne-Very hot, long and slim, good for seasoning. Pkt., 5c;

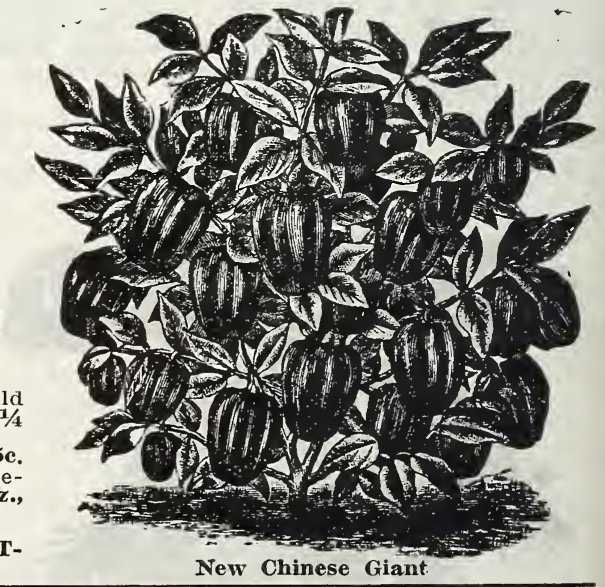

Why We Grow Sedalia the Home of Pure Seeds, is situated in the heart of the best Agricultural State in the Union. Archias' Sure Seeds are grown by Specialists and are dependable. They are annually planted in all parts of the United States by the best Market Gardeners
isfaction. We have the largest Seed establishment in Missouri, and we are growing. 
A R CH A S' SEED S TORE, SEDA L A, MISSOURI

\section{ARCHIAS' PROLIFIC PUMPKINS}

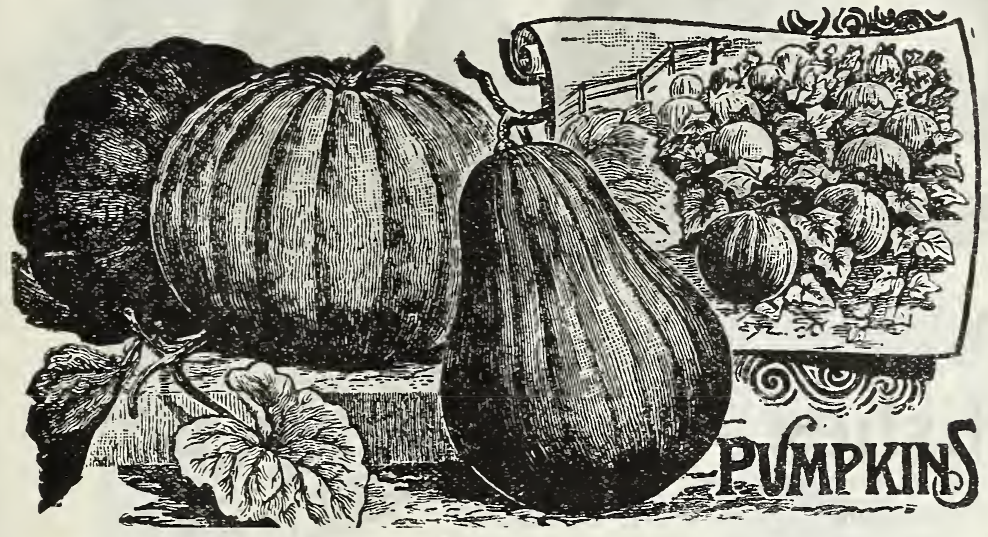

Connecticut Field, or Yankee Pie-Large size, red, ribbed. Grown for stock and pies. Prices same as Kentucky Field.

Japanese Pie - The flesh is very thick, solid, unusually fine grained, dry and sweet, resembling sweet potatoes in taste. They ripen early and keep well. Oz., 15e; $1 / 4$ 1b., 45c; 1 lb., \$1.25.

King. of Mammoths-Flesh and skin bright golden yellow. Flesh fine grained, excellent quality. One of the best pie pumpkins and a splendid keeper. This enormous variety has been grown to weigh 200 pounds. Pkt., 5c; oz., 15c; $1 / 4$ lb., 45c; 1 lb., \$1.25.

Sugar Pumplin-Orange yellow; small size; keeps well; prolific. $\mathbf{O z}$. $15 \mathrm{c} ; 1 / 4$ lb., $35 \mathrm{c} ; 1$ lb., \$1.25.

Green "striped, Crook-Neck Cashaw-Very prolific; heavy weight, frequently weighing 60 pounds; cream color. Oz., 15c; 1/1 lb., 35c; 1 lb., $\$ 1.25$. Mammoth White Cashaw-Crook neck. One of the very best. Oz., 15c; 1/4 1b., 35e; 1 lb., \$1.25.

Mammoth Golden Cashaw, Crook Neck-Oz., 15c; 1/4 1b., 35c; 1 1b., \$1.25.

Tennessee Sweet Potato Pumpkin-Excellent for pies; pear shaped, me$\begin{array}{ll}\text { dium size, } & \text { fin., } \\ 1 \text { 1b1.25. }\end{array}$

CULTURE-Pumpkins will grow almost anywhere, but rejoice in rich soil. In many varieties the size and weight depend almost wholly on culture and fertility of the land. Plant in hills $8 \times 8$ feet. Use 3 to 4 pounds of seed per acre; $1 / 4$ pound for 75 hills. Put seed in ground in May. Plant Pumpkins in your corn. It always pays.

Large Cheese-Best variety for cooking; light yellow flesh, sweet, brittle and thick; excellent keeper. Oz., 10c; $1 / 4$ lb., 35c; 11 1b., 95e er. Kentu, 10c; 1/4 1b., 35c; 1 1b., 95e. culture in corn; fine for stock for winter feeding; grows very large wint keeps well. Grows very 1/4 lb. $20 \mathrm{c}$; qt., 40c, postpaid. Not prepaid: qt., 35c; 4 qts., \$1.00; pk. $\$ 1.75$.

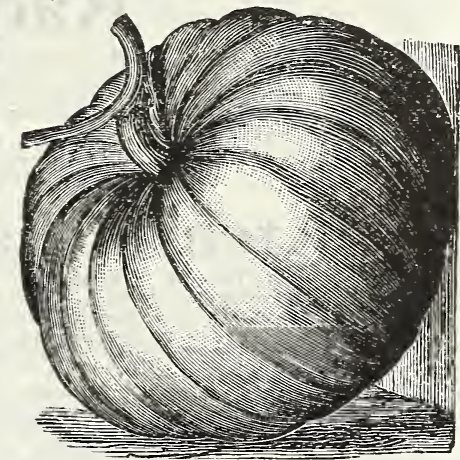

Kentucky Field

\section{ARCHIAS' BEST SQUASHES}

\section{Cream of the Squash Family-Acknowledged the Very Best}

CULTURE-About the same as melons. Make the ground very rich. A good sandy loam is best. The Squashes are all tender, and the seed should not be planted until warm weather. Allow $4 \times 4$ feet for the hills of the bush squashes and $8 \times 8$ feet or more for the running varieties. Three plants to the hill; 2 to 3 pounds of seed to the acre. For summer squashes estimate 4 ounces to 100 hills; for winter squashes 8 ounces to 100 hills. Use Slug Shot to keep down the bugs.

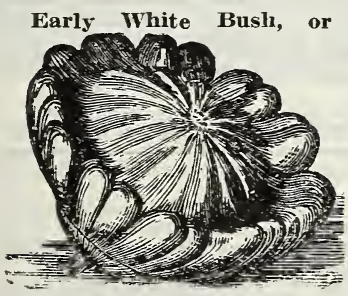

Early White Bush

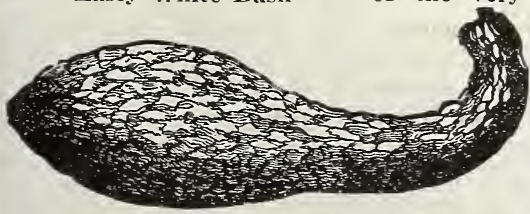

Golden Summer Crook Neck
Patty-Pan Scalloped-Light Cream color, large size. Oz., 5 .

Golden Summer Crook Neck-Quite an early and productive, warty, yellow Variety of good quality. Oz., 1 .

Vegetable Marrow - Excellent English variety for baking. Oz., 15c; 1/4 lb., $35 \mathrm{c}$; 1 ib. \$i..25. of the very best for fall and winter; f o r m oval, pointed; rind thin; bright orange; flesh
deep orange, finely grained and excellent flavor. lb., 35c; 1 lb., $\$ 1.25$.
Golden Hubbard-Good fall and winter variety of excellent quality. Oz., 15c; $1 / 4$ lb., $35 \mathrm{c} ; 1$ lb., \$1.25.

I a m m ot h Chili - Largest of all squashes, often attaining a often attaining a pounds without pounds its fine shape and good shape and good quality. The thick, of a brigh or ang e color good keeper. Oz., $15 \mathrm{c} ; 1 / 41 \mathrm{lb}$.; $50 \mathrm{c}$; I a $\mathrm{m} \mathrm{mot} h$ Pot Iron - An other large, $\mathrm{sh}$ o wy variety. Oz., 15c; $1 / 116$.

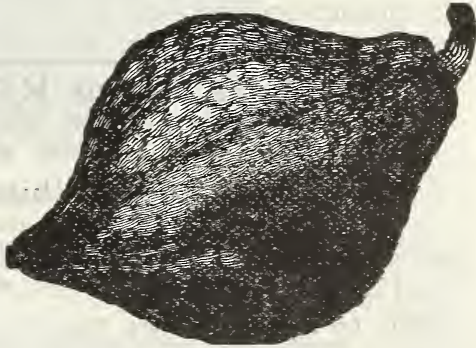

Chicago Hubbard
Hubbard (Chicago Warted)-For fall and winter use good in any climate; hard skin; good keeper; sweet and rich. Oz., 15e; 1/4 lb., 40c; 1 lb., \$1.25.

IIE PAY THE POSTAGE ON ALL GARDEN SEEDS IN TIIS CATALOG, EXCEPT O'THERWISE NOTED

A GOOD VEGETABLE GARDEN REDUCES BOTH

Ordering Your Seeds by Mail saves TME, MONEY AND DISAPPOINTMENT. Study well items forwarded immediately on receipt of order. This way you lose no time waiting at a crowded counter. If seeds are not satisfactory we refund your money. SAFE AND EASY TO ORDER BY MAIL. 
GROW "SURE SEEDS," PLANTS A ND TREES

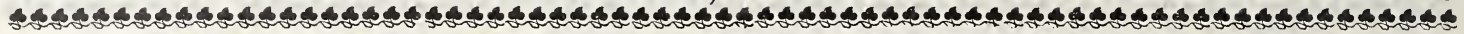

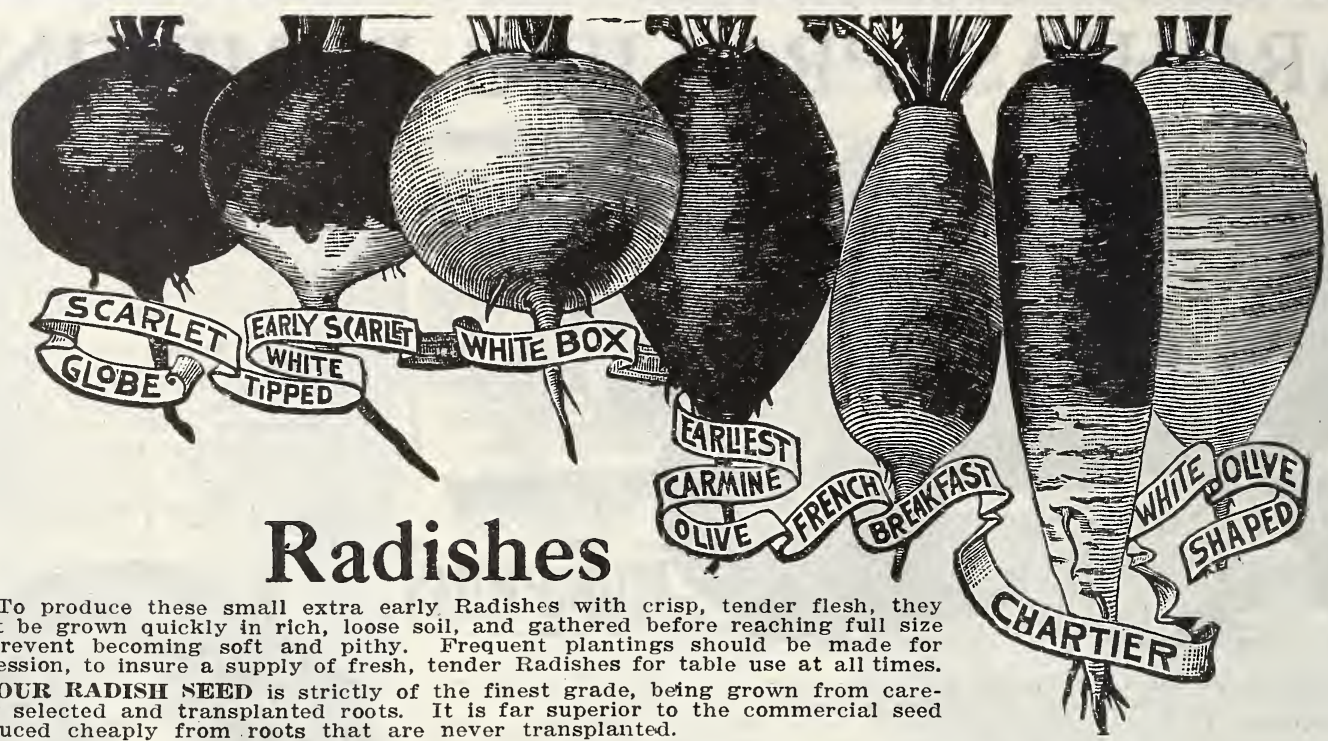

\section{Archias' Early Turnip-Shaped Varieties \\ Early Scarlet Turnip, White Tip-An early variety, of} handsome appearance; round, deep scarlet, tipped with white; the favorite for forcing out door planting. A most popular market variety, owing to its beautiful appearance and quick growth. Plst., 10c; oz., 20c; 1/4 1b.,

Early Scarlet Erfurt Turnip-This Radish is quite desirable as an early sort, and is particularly adapted to
forcing. The shape is well shown in the illustration. The color is vivid scarlet. The flesh is white, crisp, solid and mild. It has a very small top, and will bear close plant$5 \mathrm{c} ;$ oz., 15e; $1 / 4$ lb., 50c; 1 lb., \$1.75.

Earliest White Turnip-(White Box) - Of quick growth; roots round, pure white, tails very thin; leaves short; flavor excellent. Fine for forcing and open ground work. Plt., 5c; oz., 15c; 1//4 lb., 50c; 1 lb., $\$ 1.75 .75$. Turnip)-The earliest forcing Radish in cultivation; roots small, round, deep rich scarlet, crisp, tender, white flesh. Plkt., 5c; oz., $15 \mathrm{c} ; \mathbf{1} / \mathbf{1 b}$., 50c; 1 lb., \$1.75.

Archias," New Scarlet Globe-Entirely distinct, globe shaped, bright scarlet Radish, mild and crisp. Best Radish for forcing in the green house or outdoors. Stands heat well.

\section{Three Best Olive-Shaped Varieties}

French Breakfast-This pretty Radish in color is bright red, tipped with white. It is oblong in shape and in quality is crisp and tender. It is a quick grower and

\section{Archias' Long Radishes \\ FOR SPRING AND SUMMER}

All 5c Per Package Except When Noted.

\section{Archias' Long White Icicle}

Purest white skin flesh. The Radish is about six inches in length, of attractive tapering shape and of splendid quality. Matures in twenty to twenty-eight dib., $\$ 1.75$.

Early Long Scarlet, Short Top-The standard long variety for market and home garden. Roots long, growing partly above ground, straight, smooth, rich color; very crisp and a quick grower. Our seed is especid

New Brightest Long Scarlet-Fiery scarlet, the brightest color of any Radish, tipped with white; early, ma-

\section{WINTER VARIETIES}

Long Black Spanish-Very hardy and a good keeper; sow them with your turnips. Oz., 15c; $1 / 4$ lb., 50c; 1 lb., 1.75 .

Round Black Spanish-Oz., 15c; $1 / 4$ lb., 50c; 1 lb., $\$ 1.75$. excellent quality. Oz., 15c; $1 / 416 ., 50 c ; 11 b ., \$ 1.75$.

Rose Color China Winter-Very popular with market

Rosy Gem-Fine for forcing or open culture, perfect globe shaped, deep scarlet on top, blending into whit Pkt., 10c; oz., 20c; $1 / 4$ lb., 60c; $1 / 2$ lb., 90c; 1 lb., $\$ 1.75$.

Large White Summer Turnip-Larger than Early Turnip, and later. Oz., 1.5c; 1/4 lb., 50c; 1 lb., \$1.75.

Yellow Summer Globe-Excellent for summer, large, russet color. Oz., 15c; 1/4 lb., 50c; 1 lb., \$1.75.

\section{Archias' New Triumph Striped}

(Twenty-Day Radish)-Its tops are very short; valuable for cultivation under glass. The flesh is very crisp and solid, and of mild flavor. Pure white, striped horizontally with bright scarlet. It is a most attractive ornament for the table, and market gardeners will find ready sale

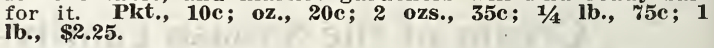

Mixed Early Turnip Radish Seed-A select mixture of the most desirable Turnip sorts. Oz., 15c; $1 / 4$ lb., 50c; 1 lb., \$1.50.

is still an exceedingly popular variety. Pkt., 5c; oz., $15 \mathrm{c} ; 1 / 1 / 1 \mathrm{lb} ., 50 \mathrm{~s} ; 1 / 2$ 1b., 90c; 1 lb., $\$ 1.75$.

Olive-Shaped Early Çarmine-Very early; olive shaped: bright scarlet skin; flesh firm and crisp. Oz., 15c; 1/1 lb. 50c; 1 lb., \$1.75.

Olive-Shaped Early White-Handsome small white variety; sweet and crisp. Oz., 15c; $1 / 4$ lb., 50c; 1 lb., $\$ 1.75$.

turing in 20 to 25 days; crisp and tender. Oz., 15c: $1 / 4$ lb., 50c; 1 lb.j \$1.75. Barteldes Glass - A long Radish of light pink color, named "Glass Radish" on account of the transparency of the flesh. Oz., 15c; 1/4 1b., 50c; 1 lb., \$1.75.

White Vienna or Lady Finger-Pure white, long fine grain, tender and of excellent flavor. Oz., 15c; 1/4 1 ., 50c; 1 lb., \$1.75.

Chartier, or Shepherd-Very handsome, tender and crisp, and does not become pithy or hollow. A deep crimson at the top and shading off to white at the bottom. Oz., 15c; $1 / 4$ lb., 50c; 1 1b., $\$ 1.75$.

\section{White Strasburg}

One of the most satisfactory varieties grown. of large size, producing uniform, long, smooth, pure white roots of excellent quality. Always solid and crisp, resisting heat to a remarkable degree. Fine for summer and autumn. Pkt., 5c; oz., 15c; $1 / 4$ ib., 50c; 1 lb., $\$ 1.75$.

gardeners; very smooth, bright rose color; large. Oz., $15 \mathrm{c} ; 1 / 4 \mathrm{lb}$., 50c; 1 lb., \$1.75.

California White Mammoth-Eight to twelve inches long, and about two and one-half inches thick; solid and tender; a very good fall variety. Oz., 15c; $1 / 41$ lb., 50c; 1 lb.. $\$ 1.75$.

Mixed Winter Radishes-A mixture of the best fall and winter varieties; sow broadcast with turnips; sure to please. Oz., 15c; $1 / 4$ lb., 50c; 1 lb., $\$ 1.75$. 
A R C I A S , SEED STORE, SEDALIA, MISSOURI

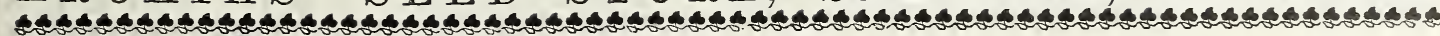

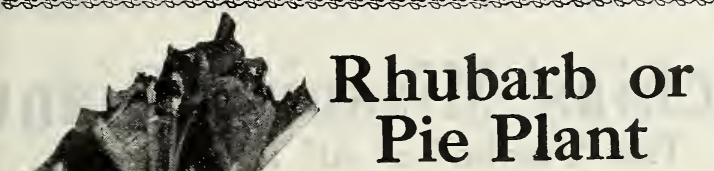

Rhubarb is very hlghly esteemed for use in pies, tarts, jelly and marmalade and large quantltles are sold in all markets every year. It ls the first artlcle of the season from the garden, and no private garden should be wlthout it. Sow in drllls one foot apart early in the sprlng. In the fall or next spring transplant very rich soil. Excellent for pies or tarts.

Archias' Mammoth Victoriathe largest and most productive variety known. The leaf stalks are very numerous, the larger ones belng 15 to 20 inches in length and fully $1 \frac{1}{2}$ inches wlde. The whole plant is nearly $51 / 2$ feet in diameter, whlle the leaves, exclusive of the flower stalks, are about $2 \frac{1}{2}$ feet in height. It is the first article of the season from the garden, and no prlvate garge pkt., 10c; oz., 25c; 1/4 1b. \%5c.

Linneaus - Large and tender; very fine. Oz., 20c; $1 / 4$ 1b., 60c. Myatt's Victoria - Very large, popular variety. Oz., 25c; 1/4 1b., pope.

Market Gardeners Wanting Large Quantities of Seeds Should Write for Special Prices, Stating Quantity Wanted.

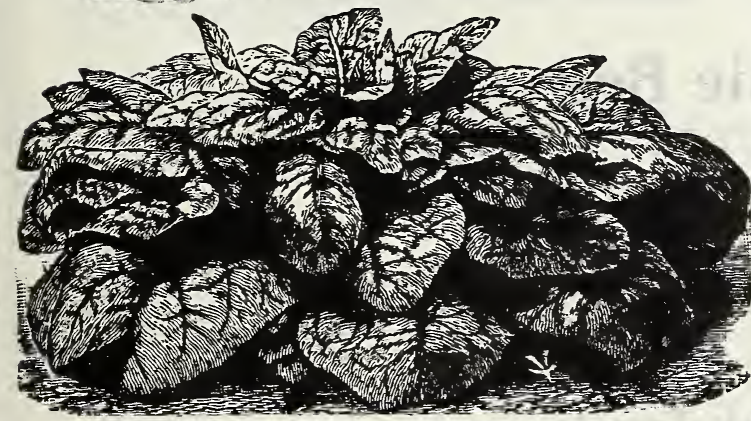

Archias' New Long Standing

Archias' New Long Standing - The best variety to sow in Spring and also continuously all summer, as it remalns firm and fresh during the hot summer months. The leaves are thicker and heavier than those of any other sort; they are heavily crumpled and bllstered, of dark green color, and do not wilt or run to seed as quickly as any other kind.

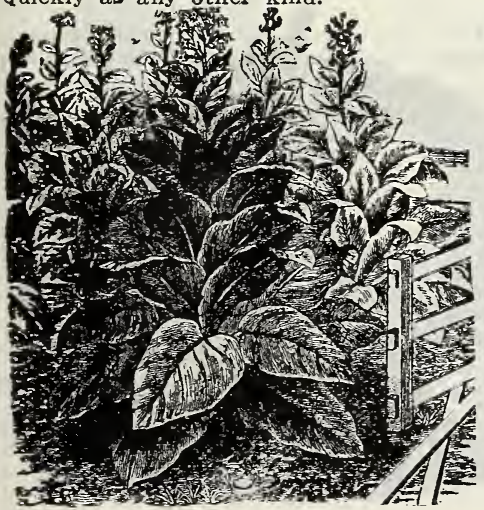

\section{Archias' Pedigreed Tobacco Seed BEST VIRGINIA GROWN SEED}

\section{Wrapping and Smoking Varieties}

Havana-Grown from seed imported from Vuelta de Abajo. Per pkt., 10c oz., 40c.

Connecticut Seed Leaf-An old, well known variety. Per pkt., 5c; oz., 30c $1 / 4$ lb., $\$ 1.00 ; 1$ lb., $\$ 3.25$, postpaid.

\section{Shipping and Fine Cut Varieties}

Gold Leaf-Similar to Yellow Prior. Pkt., 5c; oz., 30c; 1/4 1b., \$1.00. Improved White Burley-Thls strain is much superior to the regular White urley. Per pkt., 10c; oz., 40c; $1 / 4$ lb., $\$ 1.10 ; 11$ 1b., $\$ 4.00$.

Yellow Prior-Good variety, Prite Virginia variety. ${ }^{4}$ Pkt., 5c; oz., 30c; 1/4 lb. $\$ 1.00$.

Broad Leaf Gooch-Pkt., 10c; oz., 35c; 1/4 lb., \$1.00.

Broad Leaf Gooch-Pkt., 10e; oz., 35e; 1/4tb., \$1.00., 30c; 1/4 1b., \$1.00. 


\section{A Wonderful Tree Tomato}

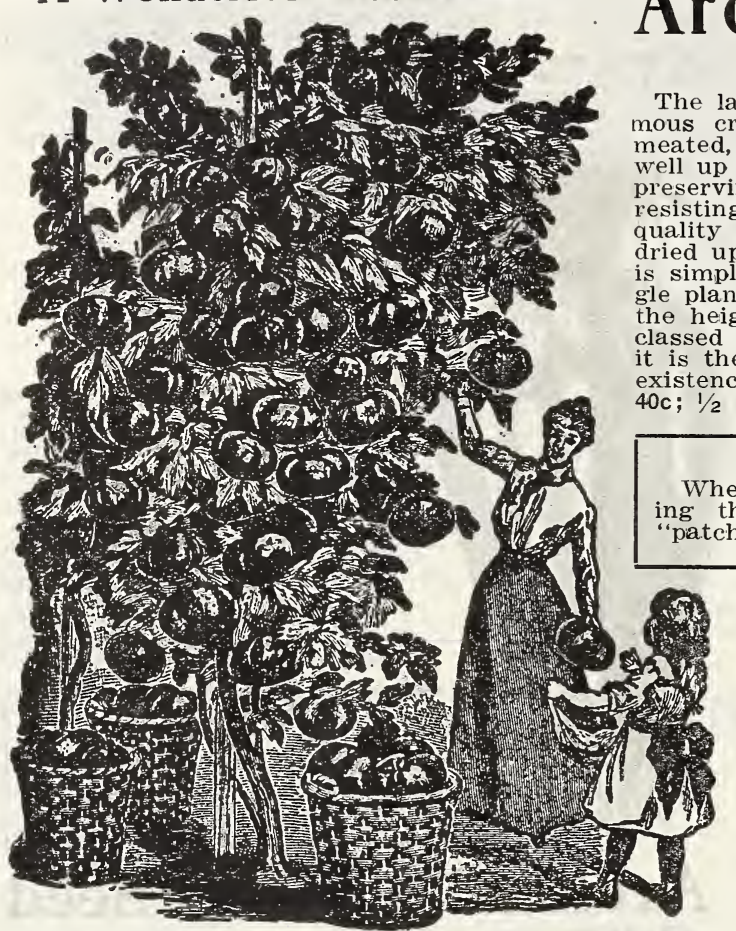

\section{Archias' Missouri Giant}

The "Jumbo" of All Tomatoes

largest fruited of the Climbing Tomatoes, bearing enorfrom early harvest until killed by frost. Solidwell up to the stem; unexcelled for keeping, shipping, canning, well up to the stem; unexcelled for keeping, shipping, canning; esisting large tomato known, holding its large size and fine during the entire summer, when other varieties are . Shape round and smooth. The yield of this tomato e plant in one picking. Well cultivated plants have attained height of 10 feet, and 9 feet across. This should not be

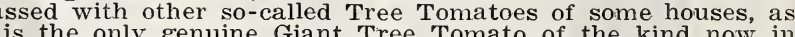
xistence. Price, full size pkt., 20c; 3 pkts. for $50 \mathrm{c}$; $1 / 4 \mathrm{oz}$., oc; $1 / 2$ oz., 75c; 1 oz., $\$ 1.25$; by mail, postpaid.

\section{MONEY IN TOMATOES}

Whether for market, home use or canning there is nothwat pays better returns than a well-kept tomato "patch." Plant Archias' Sure Seeds.

\section{Praises For Archias' Missouri Giant Tomato}

Mrs. Jas. W. Tapp, Coffeyville, Kas.-Archias' Missouri Giant are the finest I ever saw. They are giants.

James Spurlock, Fayetteville, Ark -No finer tomato ever grew than Archias' Missouri Giant.

Green Farnham, Wellsville, Okla.-My Archias' Missouri Giant outsells all others. They are simply grand; some weigh over a pound.

Mary Jameson, Sparta, Ky.-Have sold over ten bushels tomatoes from my Archias' Missouri Giant plants and they are still bearing.

\section{Bonnie Best}

Bonny Best-Large smooth fruit of a rich scarlet red, the color demanded by many markets. Fruit thick with a small core, an excellent tomato for any purpose. Slices exceptionally well. Nearly globe shaped, slightly flattened at stem. Bore in clusters of 5 or 6 fruits, all ripening evenly together. Pkt., 10c; 1/2 oz., $25 \mathrm{c} ;$ oz., $40 \mathrm{c} ; 1 / 4 \mathrm{lb} ., \$ 1.25$.

\section{Livingston's Beauty Tomato}

The Finest Large Fruited Purple Varlety-Its beauty, size, shape, perfection, color, flavor, durability and productiveness make it desirable for all purposes; free from rot. Pkt., 5c; oz., 40c; 1/4 Ib., \$1.00; 1 lb., $\$ 3.00$.

\section{June Pink Tomato}

The very earliest and most productive pink fruited Tomato ever introduced. The habit of growth is exactly the same as the Earliana. It is enormously productive, growing to set and develop good sized fruit througho.

\section{Sparks' Earliana}

The Earliest Large, Smooth, Red Tomato-Its solidity and fine quality are quite equal to the best medium and late sorts. Pkt., 10c; oz., 35c; 2 oz., 60c; 1/4 lb., \$1.00.

Dwarf Champion-An early and distinct variety, medium in ize; plant of dwarf and compact growth. Oz., 25c; 1/4 lb., 90c 1 Ib., $\$ 3.00$.

Dwarf Stone-This is the largest fruited of all the dwarf or

"bush" Tomatoes-the growth is erect until the branches become overloaded with fruit. Foliage heavy and a rich, dark green. Fruit, bright scarlet, very smooth, firm and solid. Pkt., 5c; oz., 30c; 1/4 lb., \$1.00; lb., $\$ 3.50$.

Fordhook Fancy-Very compact; only 18 inches in height. Teaves broad resembling the potato Color deep purplish red: solid and good flavor. Pkt., 10c; oz., 35c; 2 ozs., 60c; $1 / 4$ ib., $\$ 1.00$; 1 Ib., $\$ 3.50$.

Trucker's Favorite-Fine large fruited purple Tomato; thick meated and prolific. Pkt., 5c; oz., 35c; 1/4 Ib., $\$ 1.00$.

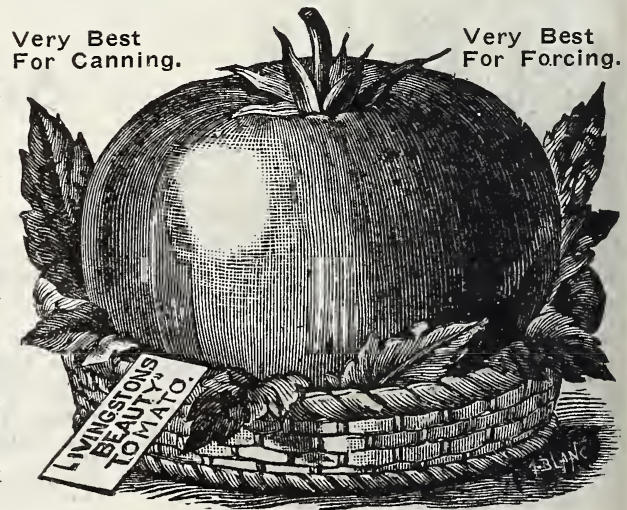


A R CHIA ', SEED STORE, SEDALIA, MISSOURI

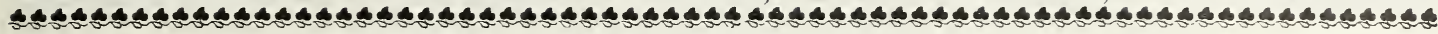

\section{Archias' Selected Ponderosa}

\section{This is the Largest} and One of the Most Popular of ALL TOMATOES

And is of flne quality for slicing. The vines are of strong growth; fruits oblong in form, through and generally ridged or ribbed; deep purple in color. They are solidly fleshy with small seed cells; of fine flavor. Planted in good soil, fruits frequently attain a weight of one pound or more. The demand for this variety increases from year to year, which is proof of Its superiority. Our price to ane and all on Archias' Selected Ponderosa is, Pkt., 10c; 3 pkts., $25 c$; $1 / 2$ oz., $25 c$; oz., $45 c$; 2 oz., $85 \mathrm{c} ; 4$ oz., $\$ 1.50$; lb., $\$ 5.50$.

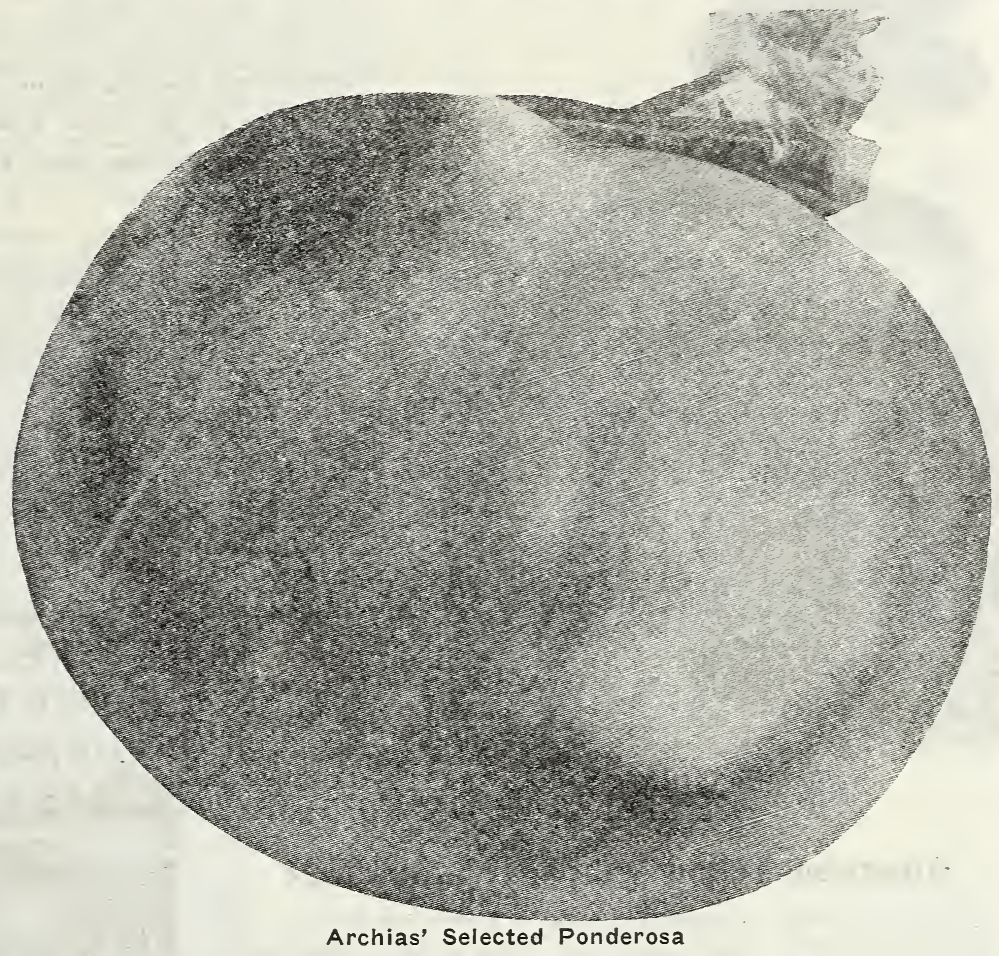

\section{Livingston's Stone Tomato}

We venture to assert that more of the Livingston's. Stone Tomato is annually being grown than any other half-dozen varieties taken together.

Introduced in 1891. This variety has obtained immense popularity with canners, southern growers and market-gardeners everywhere. Its solidity and carrying qualities are remarkable. Its color is a desirable red. Its shape perfectly smooth, and thicker from stem to blossom end than most varieties, making it very handsome and salable. (See illustration). Nobody finds any fault with this variety, but all speak in the highest terms of its beautiful color, its wonderful yielding qualities, its unequaled firmness, or some other of its good points. Pkt., $5 \mathrm{c} ; 1 / 2$ oz., $20 \mathrm{c}$; oz., $35 \mathrm{c} ; 1 / 4 \mathrm{lb}$., $\$ 1.00 ; \mathrm{lb}$., $\$ 3.50$.

Livingston's Globe-Perfectly globe-shaped, very early, large, smooth; has few seeds; firm fleshed, ripens evenly; rose-colored tinged with purple; very productive; an excellent keeper; flavor superb. A fine variety for greenhouse or for early outdoor growing. Pkt., 10c; 1/2 oz., 25c; oz., 40c; 1/4 Ib., $\$ 1.25$.
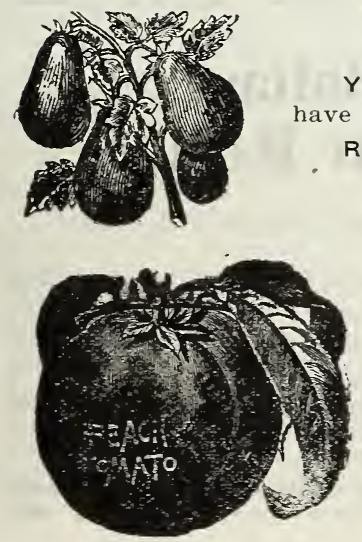

\section{PRESERVING TOMATOES}

Yellow Pear-(See illustration on the left). Similar to the Plum, but the fruits have a slim neck of distinct pear shape. Pikt., 10c; oz., 30c; 1/4 lb., \$1.00.

Red Cherry-Small fruits; used for pickles. Pkt., 5c; az., 30c.

Red Plum-Bright red; round, used for pickles. Pkt., 5c; oz., 30c.

Peach-Fruits $1 \frac{1}{2}$ inches in diameter. The skin is covered with a slight bloom or pubrescence, as in peach, and of beautiful coloring. Each, Red or Yellow Peach, pkt., 10c; oz., 30c; one pkt. each for $15 \mathrm{c}$.

Strawberry or Husk Tomato-Plants of lowspreading growth and immensely productive. The small yellow fruits are each enclosed in a husk. Of very sweet flavor, highly esteemed for preserving or making pies. They are also excellent to eat raw as fruit. Pkt., 10c; oz., $40 \mathrm{c}$.

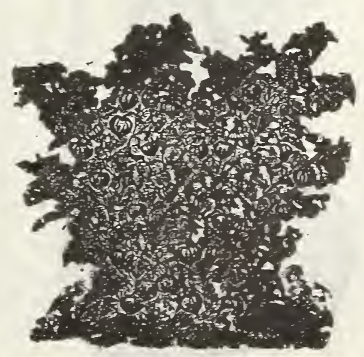

Husk Tomato. 


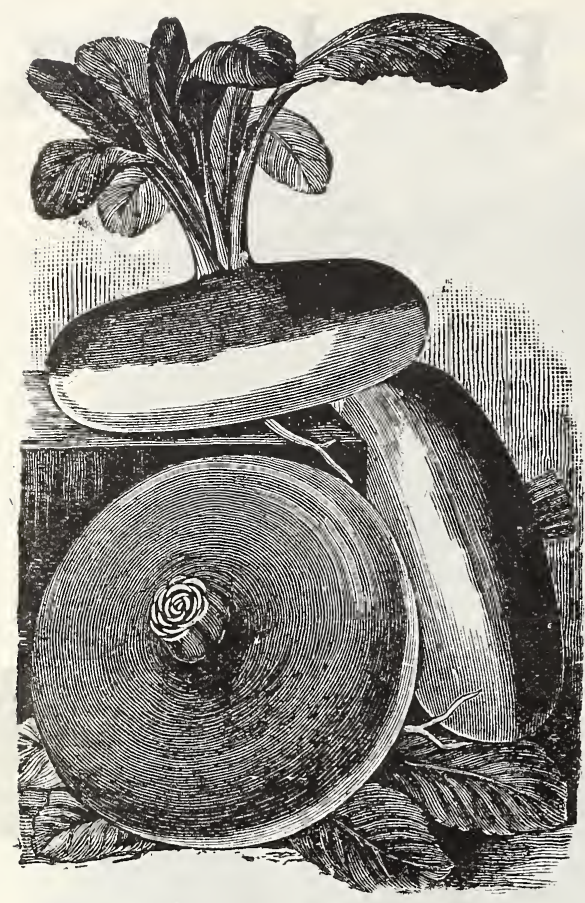

Purple Top Strap Leaf

\title{
Archias' Select Table Turnips
}

Culture-For spring crop, sow early as the ground can be worked, and none but early varieties.

For fall crop, sow middle of summer. From 1 to 2 pounds of seed are required to sow an acre. Our Turnip seed have always given the best results wherever tried. They never fail to please. Extra Early Red Top Milan-The earliest in cultivation; the bulb is flat, of medium size, smooth, with a purple top; flesh white. Oz., 20c; 1/4 Ib., 60e; 1 lb., $\$ 2.00$.

Early White Milan-Oz., 20c; $1 / 4$ lb., 60c; 1 lb., $\$ 2.00$.

Red, or Purple Top, Strap Leaf-This is the principal sort for spring and fall use; top is red or purple above ground. flesh fine grained, of mild flavor, and a good keeper. Oz., 15c; 1/4 lb., 50c; 1 lb., $\$ 1.75$.

Large Early Red Top Globe-Early, very large, globe-shaped. Oz., 15e; $1 / 4$ lb., 50c; 1 lb., \$1.75.

Large White Globe-Good for table and stock. Oz., 15e; 1/4 lb., $50 \mathrm{c}$ : 1 1b., $\$ 2.00$.

Yellow Aberdeen-0z., 15e: 1/4 1b., 50e; 1 lb., \$1.75. Golden Ball-Globe shaped, amber colored and sweet. Oz., 15e; $1 / 4$ lb., 50e; 1 1b., \$1.75.

Early Snowball-Very, fine, globe shaped. Oz., 15e; 1/4 1b., 50c; 11 1b., \$1.75.

Seven Top_For greens only; stands the winter well. Oz., 15e; $1 / 4$ lb., 50c; 1 lb., \$1.75.

Cow Horn-A very sweet, large cropper, long. Oz., 20e; 1/4 lb., $75 \mathrm{c} ; 1$ 1b., \$2.25.

Farly Flat Duteh-A white, flat, very early variety. Oz., 15e; $1 / 4$ lb., 50c; 1 lb., $\$ 2.00$.

Eg -A quick grower; flesh solid and sweet. Oz., 15c; $1 / 4$ 1b., 50e; 1 1b., $\$ 1.85$.

\section{American Yellow Purple-Top Rutabaga}

Requires a longer season in which to grow than do the turnips, and with us the seed should be sown about the first to midale of July to make large bulbs. The flesh is more solid and is richer in flavor than that of the turnips, and they will Good for stock and table use.

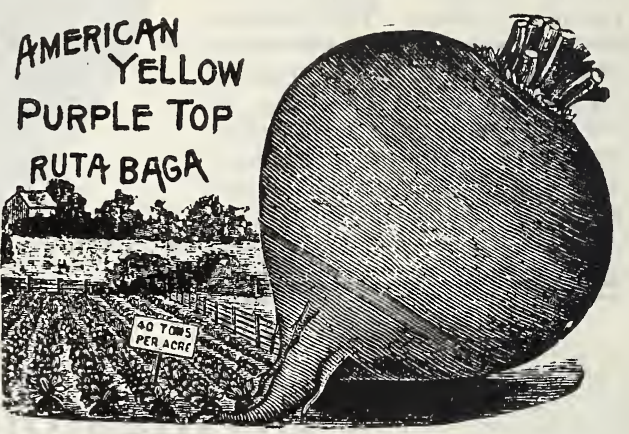

\section{Archias' Evergreen Lawn Grass}

\section{A Beautiful Evergreen Lawn for Everybody}

The owner of a cottage or bungalow as well as the possessor of an estate may now have an exact counterpart of the beautiful lawns which have made England the garden spot of the world for ages by sowing Archias' Evergreen Lawn Grass Seed.

For description and price of Archias' Evergreen Lawn Grass Seed see Inside Front Cover. Don't fail to ask for free leaflet on Lawns with your order for lawn grass seed.

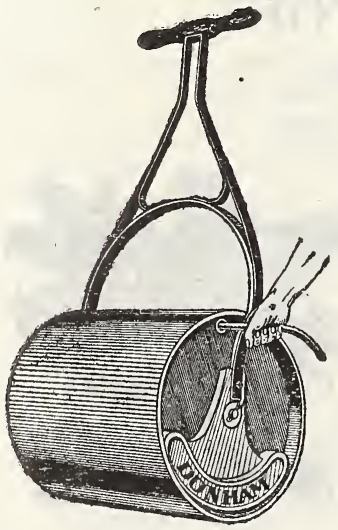

\section{Archias' Water Ballast Roller-Bearing Lawn. Rollers}

\author{
The Best and Only Roller Bearing Lawn Roller Made. Length and Weight \\ Precisely as Listed.
}

Rollers are smooth on face and aluminum finish, outer edges rounded to avoid cutting up the lawn.

Water Ballast Roller No. 7-Weight 100 pounds empty, 400 pounds filled with water, and 700 pounds filled with sand: is 24 inches in diameter and 24 inches long; is all steel and most practical roller on the market. Only $\$ 15.00$. No. 3 same as No. 7 , weighs 60 pounds empty or 200 pounds filled with water, 300 pounds filled with sand. Our price, only $\$ 10.00$.

Booklet, "The Proper Care of Lawns," will be sent free on application.

Odorless Lawn Fertilizer-10 lbs., 50c; 25 lbs., $\$ 1.00 ; 50$ lbs., $\$ 1.75 ; 100$ lbs., $\$ 3.00$.

Sheep Guano (for Lawns)-The very best brand on the market. 25 lbs., 90 c: 50 lbs., $\$ 1.60 ; 100$ Ibs.: $\$ 2.50$. 


\section{ARGHIAS' SUPERIOR RE-CLEANED GRASS AND CLOVER SEED}

Prices-As prices on grass and clover seed are always changing we give no prices by the bushel, but will eheerfully give them on application.

With Order-Express or freight charges always to be paid by the purchaser. Drayage free.

Safe Delivery Guaranteed-On all grass seed we guarantee safe delivery. If shipment arrives in bad order we

will make good any loss upon receipt of the proper papers for making
right with you and then settle with the railroad companies ourselves.

\section{The Best is the Cheapest-Poor Seeds are Dear at any Price}

\section{Clover seed}

Medium Red CloverThis is the most important of all clovers and the standard everywhere for known as Common Red or known as er in many secJune Clover grows to pertions. Clover grows Missouri, ection here in grown here and the seed grown here is the best in the world. It is bright and plump and almost universally free from bad weed seeds of all kinds. We have had a splendid crop of clover seed this year and can offer special inducements in the way of price. 40c per ib., postpaid. Write for special prices in peck or bushel lots.

Mammoth Red CloverThis is a larger, later variety of clover, somewhat resembling the ordinary medium Red or June Clover. It is much ranker in growth, and is not suited to rich land. It is of value on thin land where other clover will not grow. It will also stand extremes of heat, wet and cold better than ordinary clover. it generally ranges in price thent rame as ordiabout the same as ordinary clover, or from to $50 \mathrm{c}$ per bushel highe

Alsyke Clover (Swedish Clover)-A hybrid between red and white clover. It has a bloom somewhat like

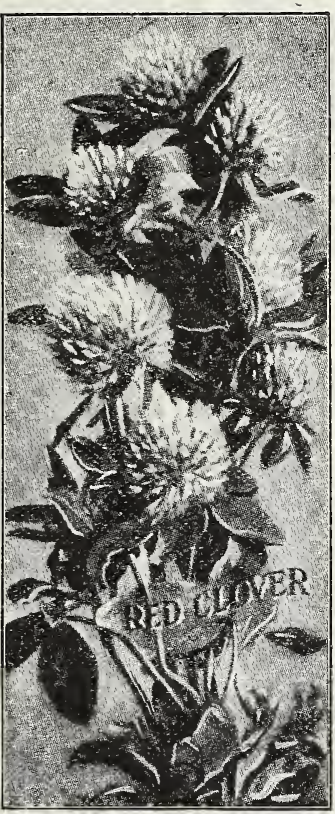

Red Clover white clover, but more pink in color. It is especially suited to low, wet land where red clover will not thrive. It will grow on land that is almost swamp and with in time dry out grown on it It will also grow on thin, sandy land or stony hillsides where red clover would not catch. The seed is very small and goes much farther than ordinary clover. Lb., 40c, postpaid. Prices subject to change. White Clover (Dutch Clover)-This is the low, creeping clover that is used so much on lawns and in lowland pastures. It is the hardiest of all clovers, will grow anywhere and is of considerable value, especially in pastures. Lb., 65c, postpaic.

Scarlet, or Crimson Clover-An annual variety, for feeding green, and for hay; sown in April or May; also the latter part of summer and fall. Sow 12 pounds to the acre. Lb., 20c; postpaid,.30c.

White Bokahara, or Sweet Clover-Tall shrub plant. Grows to 6 feet high, with branches whose extremeties bear abundant small, white, extremely fragrant flowers. Splendid for bees. Sown in the spring in drills 10 inches Ibs., \$1.75; 10 lbs., \$3.00.

Clover Farming-By Henry Wallace, editor of Wallace's Farmer. A concise, condensed handbook of Growing Clover for Hay,
naper eover, 25c, postpaid.

Inoculation of this seed with Farmogerm means a stronger catch and better yield. (See page 36 ).

\section{Grass Seed}

Any Grass, Fodder or Forage Plant You Want and Do Not Find Quoted, Write for Special Prices.

Tall Meadow Oat (Avena Elatior)-Grows luxuriantly. Sown in the fall it will be 3 to 4 feet tall in June. As soon as it blooms it is ready to cut. Sow 30 pounds to the acre. Lb., 35c, postpaid; by express, lb., 30c; 20 lbs.,
Timothy-There is lots of timothy seed grown here, and just east of us they. raise thousands of acres, so we are in good shape to supply you with grade it up carefully and give you the strictly fancy article. We guarantee it free from Red Top and free from dangerous weeds. 20c per 1b., postpaid.

Meadow Fescue, or English Blue Grass (Festuca Pratensis)-This is excellent for hay when sown with other grasses, such as orchard grass and timothy. and is also one of the best grasses for permanent pasture in a great variety of soil. Sow 30 to 40 pounds to the acre. Lb., 30c, postpaid; 10 ibs., \$2.50, not prepaid.

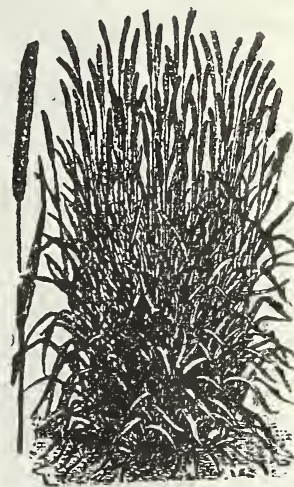

Timothy
Orchard Grass-A valuable grass for pasture on hay land and especially good in new timber pasture. It furnishes the first green bite in the spring and the last in the fall. It is well suited to shady places, such as orchards and groves. Sow 14 pounds per acre. Lb., 35e, postpaid.

Canadian Blue Grass-Somewhat similar to Kentuck blue grass, but smaller, and growing closer to the ground. Valuable in thin, stony land and for mixing with other grasses for a permanent pasture. Price subject to change, 30c a pound, postpaid.

Red Top (Agrostis Vulgaris)-Valuable for hay; arso ( Best grade, not prepaid. 1 lb., 30c; 10 lbs., \$2.50.

Johnson Grass (Sorghum Halapense)-Perennial grass, with long, cane-like roots. Leaves, stalks and panicles resemble those of sorghum. 25 to 30 pounds are sown to the acre. Lb. 35e, postpaid; by freight or express, lb., 30c; 20 lbs., \$5.00.

Rhode Island Bent Grass (Agrostis Canina)-A very fine variety for lawns. Lb., 35c.

Kentucky Blue Grass-(Poa Pratensis) -It is the best pasture for the climate and soil, succeeding finely on hill lands, and producing the most nourishing food for cattle, retains its qualities to a late period in winter. Sow early in spring or during the months of October and Novemper. Fancy clean seed, lb, 40c, postpaic not postpaid, io lbs., $\$ 3.50$.

Italian Rye Grass (Lolium Italicum)-Thrives in almost any soil, and yields early and abundant crops. Sown in the fall will produce an excellent hay crop the following season, but lasts only one year. Lb. $25 \mathrm{c}$, postpaid.

Bermuda Grass (Cynodon Dactylon)-One of the most valuable grasses for pasture and hay in the South, where it will stand indefinitely if plowed and harrowed in the spring once every four or five years. Bermuda grass has generally been established by planting the roots. However, It is just as easy to get a

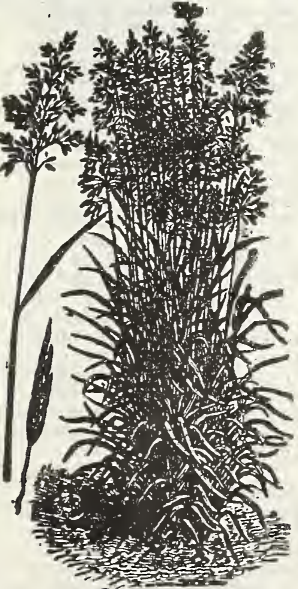

Kentucky Blue Grass sown. Sow from March to July at the rate of 8 or $10 \mathrm{lbs}$. per acre. Do not cover more than half an inch. Best grade of new crop seed, thoroughly recleaned. Lb., 90c, postpaid; not postpaid, 80c. 


\section{ARCHIAS' Hay and Pasture Grass Mixtures}

The amount of seed necessary to sow an acre depends largely on the quality of the land; the poorer the soil the larger the quantity of seed required. A fair average thicker seeds are sown the sooner will a fine, close turf be obtained.

\section{Archias' Meadow Mixture}

This mixture is composed of the following grasses and clovers, blended in the proper proportions. Meadow fescue, tall meadow oat grass, orchard grass, perennial rye grass. timothy, red clover, alsike clover.

Price, 10 lbs., \$3.00; 25 lbs. (about enough for one acre), \$6.00.

\section{Archias' Pasture Mixture No. 1}

This mixture contains some of each of the following, properly proportioned:

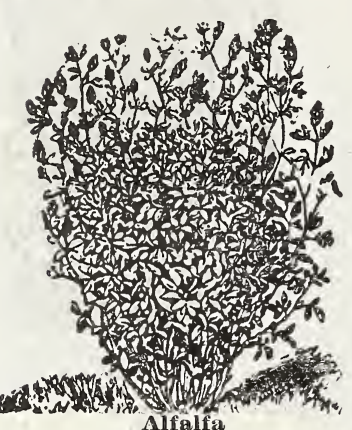

Alfilfa Red top, orchard grass, Sheep's fescue, perennial rye grass, meadow fescue, Kentucky blue 10 lbs., \$3.00; 35 lbs. (about enough for one acre), $\$ 9.50$.

Special mixtures for meadow and pasture grasses made up as required. We carry a full stock of field grasses. Prices on application. Screenings for Wooded Pasture-\$5.00, $\$ \% .00$ and $\$ 10.00$ per 100 pounds.

\section{Alfalfa or Lucerne}

\section{(Medicago Sativa)}

An absolute necessity, in the West, for the cheapest production of beef, pork, mutton, honey and milk.

In feeding value it ranks higher than red clover or timothy hay. Once a good stand is sefrom to fifteen years, gives three to six cuttings per year, yielding from three to four tons per acre. Sow in rich, moist loam or sandy soil, having a deep subsoil. Prepare the land thoroughly and sow seed at the rate of 15 to 20 pounds per acre, with a broadcaster or grass seeder. Cover with a brush or light harrow. Young plants are quite tender, and the land must be free from weeds until they become seed is absolutely necessary for the best results of the crop.

Ask the Agricultural department at Washington to send you Bulletins Nos. $105,56,133,215,97,259,194,124,162,267$, from which you can secure information respecting this wonderful plant. No other seed is attracting the attention alfalfa seed is this year.

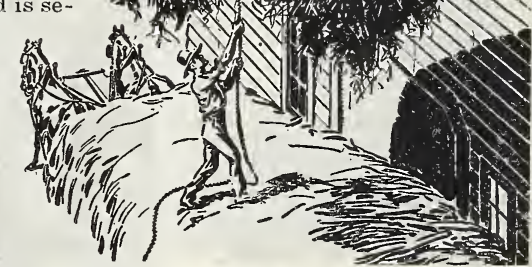

\section{Sudan Grass-A New Forage Crop of Immense Value to the Middle West}

The U. S. Department of Agriculture introduced this new forage plant into the in in 1909 the seed being brought from Sudan, Egypt, and seed produced was distributed the following year to experiment stations of the different states. The fifth crop has been grown in the United States unde widely varying climatic conditions. The results have been so satisfactory that it is now espermanent forage crops. Sudan is a tall, annudan is a tall, annual grass, reaching a nine feet when planted nine feet when planted in rows and allowed to mature for a seed crop; broadcasted and cut "in the bloom" for

hay is softer than Johnson Grass or sorghum, the stems are It is, however, entirely

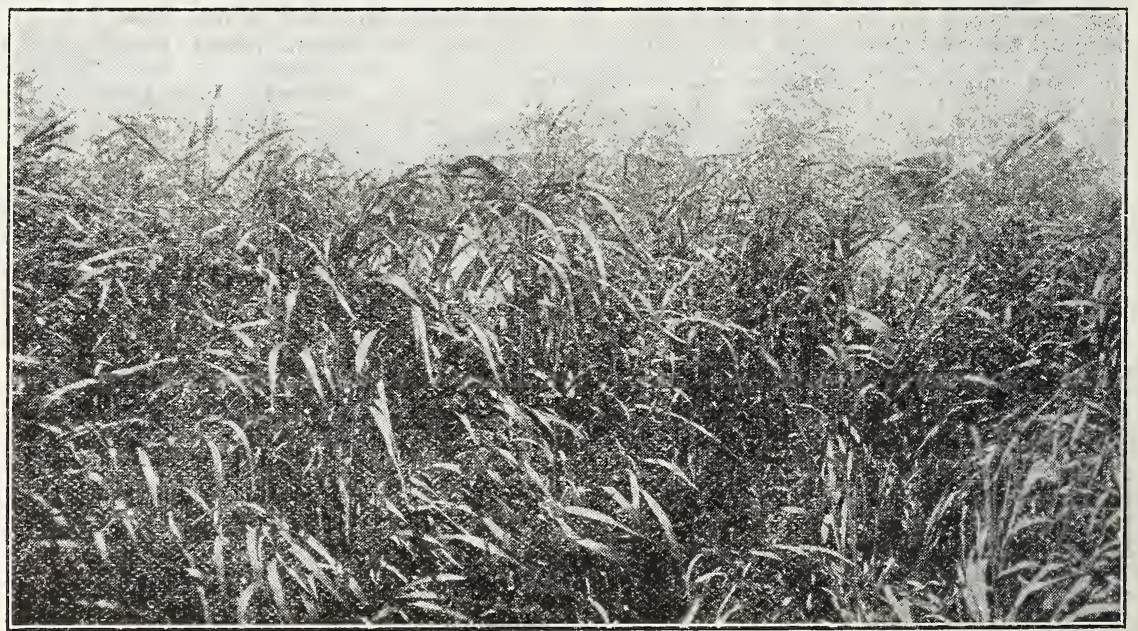
It is, however, entirely

an annual, hence not spreading like Johnson Grass. It an annual, hence not spreading like Johnson Grass. It seeded each spring. It stools very freely, throwing out many stems from or

It is easily cured and handled as a hay crop. Stock of all kinds eat it readily and will leave any other hay for it.

For a seed crop plant 2 lbs. seed per acre in rows 36 inches apart. For hay lbs. to acre. Yields 500 to $1,000 \mathrm{lbs}$. seed or three tons cured hay per cutting per acre with three cuttings per season. Price, 35c per lb., postpaid. Not postpaid, $1 \mathrm{~b} .{ }^{2}$ 1b. lots. 
A R C I A S, SEED STORE, SEDALIA, MISSOURI

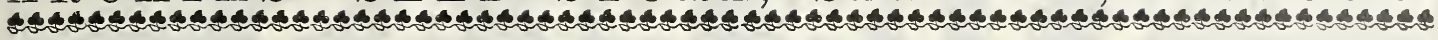

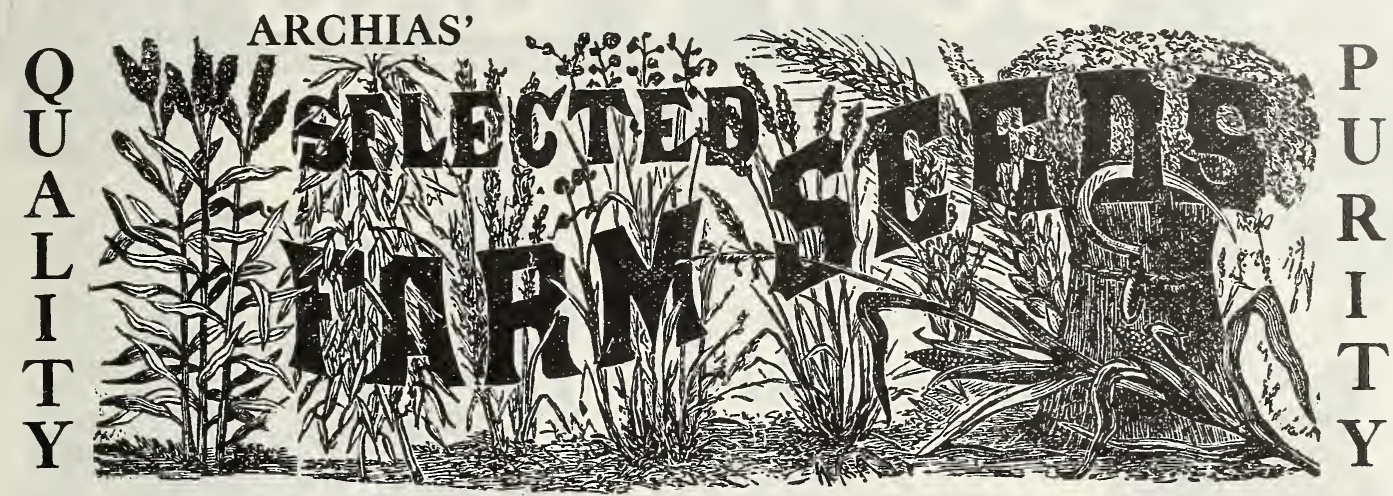

\section{MONEY GROWERS AND MORTGAGE LIFTERS}

Our Farm Seeds, Seed Corn and Grass Seeds are largely raised for us and are of the finest grown. We are always on will increase your yields and swell your profits. Our improved machinery for re-cleaning and grading seeds and grain is strictly up-to-date. Mr. Farmer, do not plant your seed simply because they are cheap. Cheap seeds are dear at any price.

The Best is the Cheapest

\section{ARCHIAS' "SURE SEEDS" \\ Are The Best}

THRMS CASH-With order. Prices subject to fluctuation. The following prices include free sacking and free drayage to depot, Sedalia. Express or freiglit charges always to be paid by purchaser. If wanted sent by mail add $15 \mathrm{c}$ per qt., or $8 \mathrm{c}$ per pound extra to pay postage.

\section{Barley}

White Hulless Barley-No beards or hulls; great for feed. Almost as heavy as wheat and yields nearly twice as much.

Price: 1 lb., 20c; $1 / 2$ pk., 60c; pk., \$1.00; 1 bu., \$3.50; 2 bu., \$6.25. Sacked free.

Champion Beardless Barley-1 lb, 20c; 1/, pk., 45c; 1 pk., 85c; u., $\$ 3.00 ; 2$ bu., $\$ 5.75$. Sacked free.

(1) staple variety where grown for brewers. It is equally as good for feeding, not having. as long beard as some other kinds. Lb., 15c; 2 lbs., $25 \mathrm{c}$; pk., $75 \mathrm{c} ; 1$ bu., \$2.75; 2 bu., \$5.25.

\section{Broom Corn}

\section{ARCHES' IMIPROVEI TVERGREEY}

This broom Armen well, and is entirely free from crooked brush. The fiber is long and fine. Its great value is that it will not get red in the field before it is cut, but is strictly a green variety of brush commanding high price. Lb., $20 \mathrm{c} ; 5$ 1bs., 75c; pk., \$1.25; bu., \$4.00.

California Golden $-\Lambda \mathrm{n}$ excellent standard variety; grows a very fine bush of good length, and is free from the larger center stem. Bleaclies very evenly in the sun. Lb., 20c; 5 lbs., 75c; pk., \$1.25; bu., $\$ 4.00$.

\section{Japanese Buckwheat}

This is the most productive of all buckwheat, a week earlier than Silver Hull, and the yield is nearly double; the kernels are twice as large as any other variety and are a richer color; best for bees. Per lb., 15c; pk., \$1.00; bu., \$3.60.
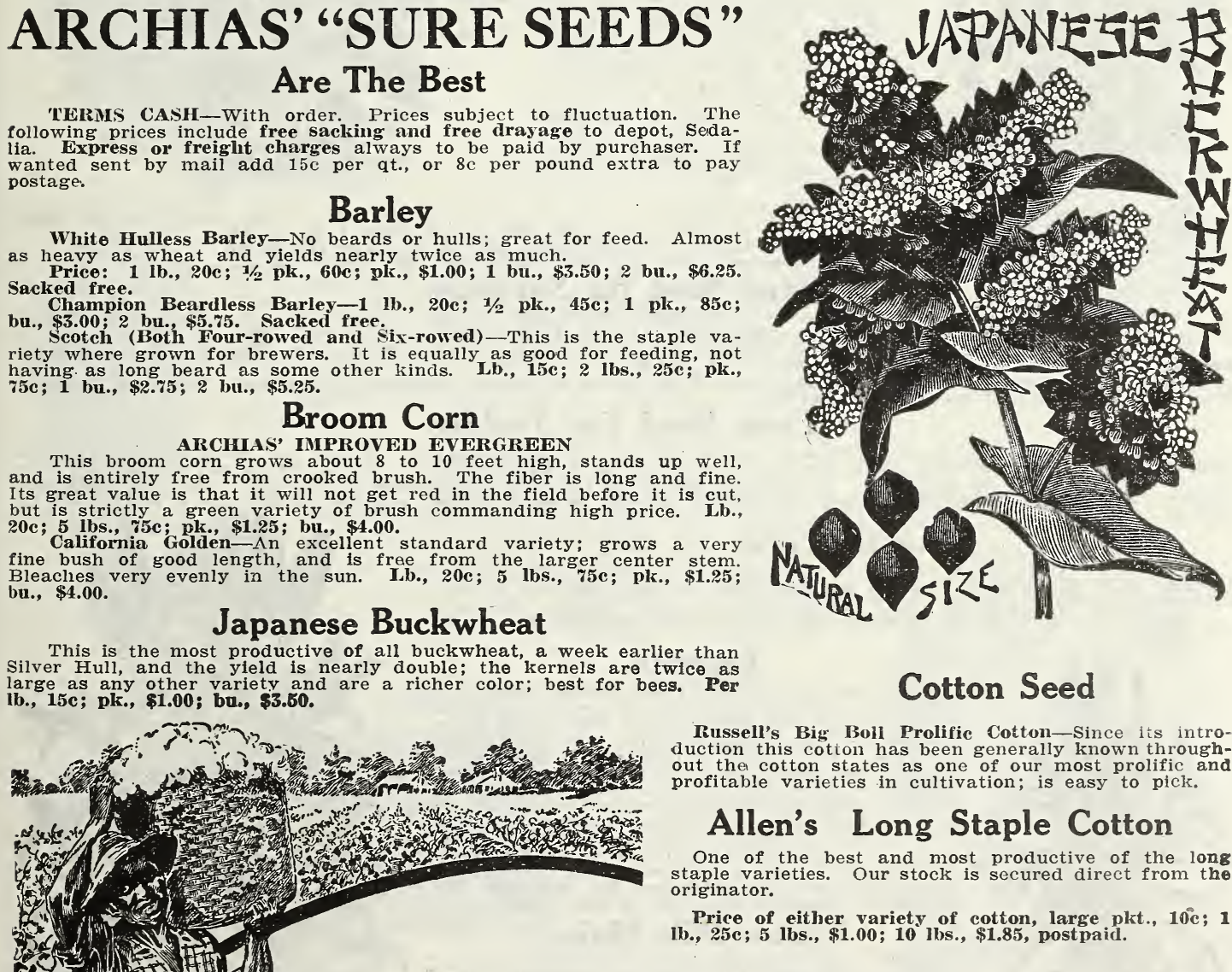

Russell's Big Boll Prolific Cotton-Since its introduction this cotton has been generally known throughout the cotton states as one of our most prolific and profitable varieties in cultivation; is easy to pick.

\section{Allen's Long Staple Cotton}

One of the best and most productive of the long staple varieties. Our stock is secured direct from the originator.

Price of either variety of cotton, large pkt., $10 \mathrm{c} ; 1$ lb., 25c; 5 lbs., $\$ 1.00 ; 10$ lbs., $\$ 1.85$, postpaid.

\section{Speltz, or Emmer}

An extremely productive grain, resembling oats, requiring same culture. Will grow anywhere. Can be fed same as oats, or cut while green and used for fodder. It makeg a better quality of hay than millet, and outyields it three-fold. Should be sown very early

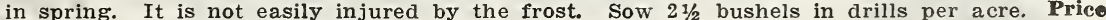
of recleaned seed: Pk., $65 \mathrm{c}$; per bu., 40 lbs., $\$ 2.50 ; 2$ bu. for $\$ 4.75$. 


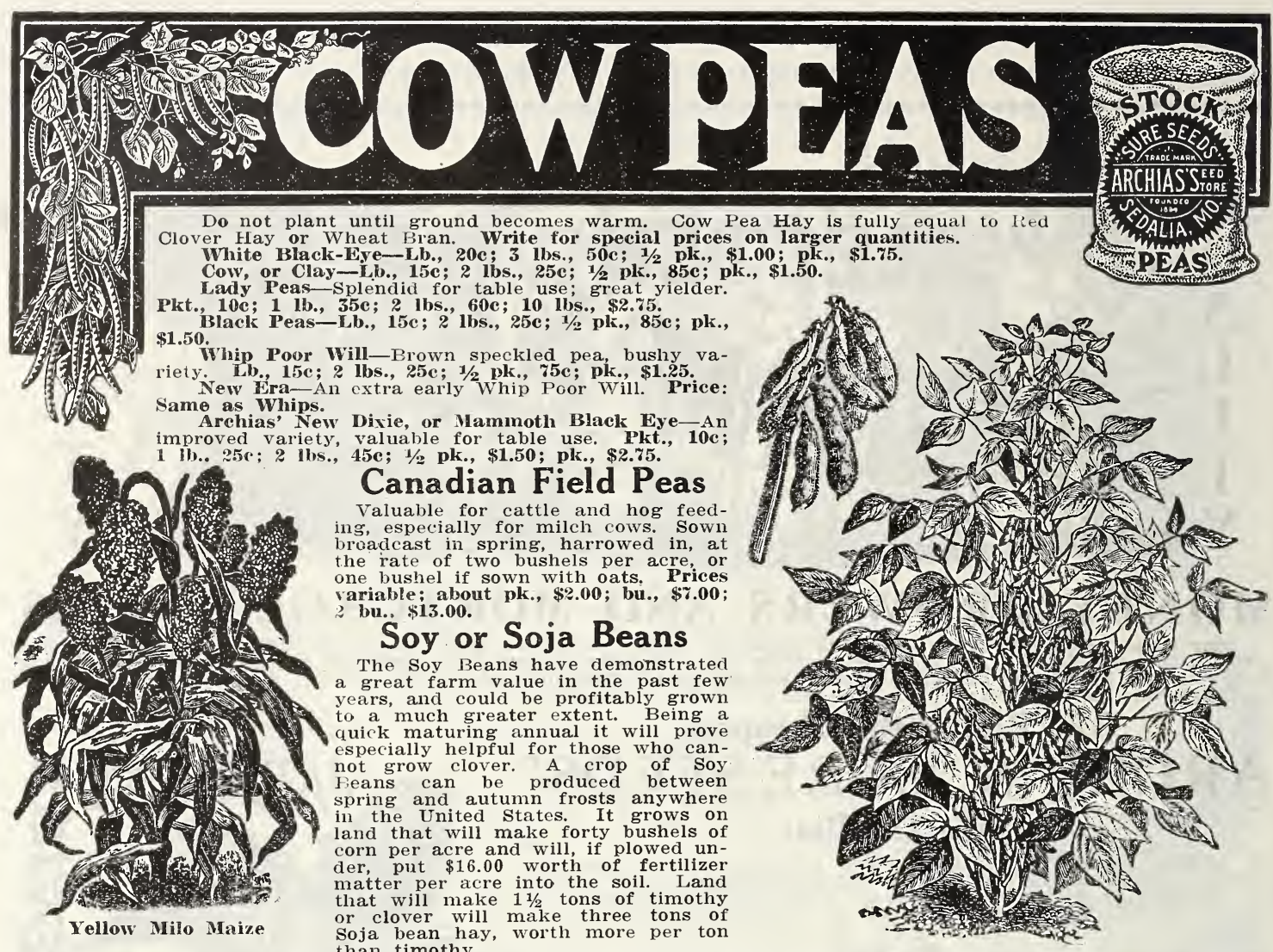

Mongol Yellow-An early bunch variety, very prolific, a popular sort; seeds small. 1 qt., 30c; $1 / 2$ pk., 85c; pk., \$1.50. Black Beauty-Dark foliage; black seed; matures early. Qt., 30c; 1/2 pk., 85c; 1 pk., \$1.50.

Inoculation of this seed is absolutely necessary for tro best results from this crop. See page 36 .

\section{Cane Seed for Sorghum}

Golden Drip, or Honey Cano-Makes the finest sorghum of any variety. Stalk large and full of sap, 25e per 1b.; 5 lbs., 85c, post paid. By express or freight, 5 lbs., $75 \mathrm{c} ; 1$ pk., $\$ 1.25$.

Early Orange Cane-A strong grower; staik heavier and a little later than Amber. Best seed. 20c per 1b., postpaid. By express or freight, 5 lbs., $60 \mathrm{c} ; 1$ pk.. $\$ 1.00$. Carly $\Lambda m b e r$
By express or freight, 5 lbs., 60c; pl., $\$ 1.00$.

\section{Cane Seed For Fodder}

Cane seed is also now largely grown for stock feediı. It yields heavily. It can be raised anywhere and is sown extensively in dry sections where tame grasses can not be grown readily. Cattle, horses and sheep relish it greatly on account of its sweetness. For forase sow 50 to 100 pounds broadcast to the acre. We sell many cargreatly on account of its sweetness. For forage sow 50 to 100 pounds broadcast to the acre. We sell many carKaffir Corn

One of the best things offered of late years for a forage plant. It is greedily eaten by horses and cattle, and makes an excellent food for poultry, either fed in grain or ground and cooked. Grows on land too poor for corn. bu., \$3.50.

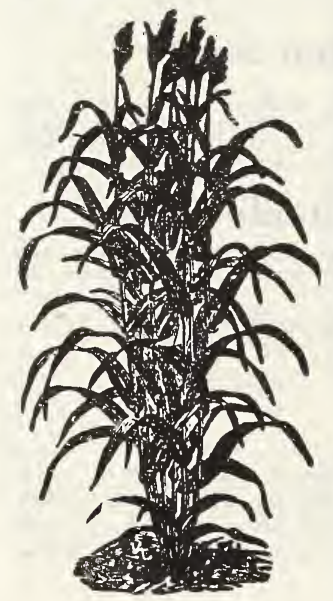

Feterita

The Great New Drouth-Proof Forage Plant-You have, no doubt, read about the wonderful yield made by this new grain during one of the wors dronths that the Middle West has ever experienced. Feterita is from 20 to 50 days earlier than kaffir corn, is not bothered by chinch bugs, makes good fodder; in some instances made an excellent yield of grain without having received any rain from the day it was planted until it was harvested. No variety of seed of any kind has ever sprung so suddenly into such popular favor. Feterita has taken the country by storm. Be sure and include it in express or freight, 5 ibs., $75 c ; 10$ libs., $\$ 1.00$.

\section{Yellow Milo Maize}

Stools well immense heads and stands severe drought. Postpaid, 1 lb., 20c; not postpaid, 5 lbs.

\section{Shallu}

Also called California Rice Corn, California Wheat and Egyptian Wheat. It grows tall, stools out from the root, making three to six stalks; makes excellent fodder. It makes fine chicken flour. Price, 20c per lb., postpaid; not postpaid, lbs. $25 \mathrm{c} ; 10$ lbs.

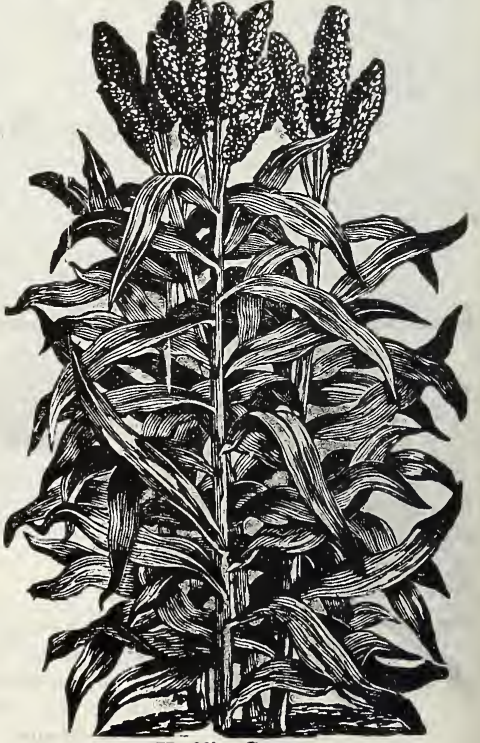


A R CH A S' SEED STORE, SEDA LIA, MISSOURI

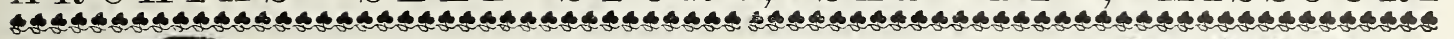
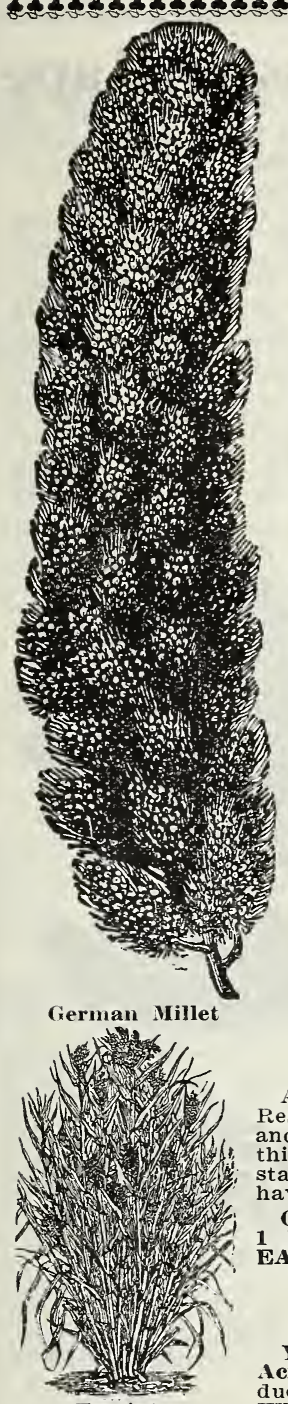

Teosinte
German Millet

\section{Archias' Big Yielding Millets}

GERMAN MILLET-It has produced from four to five tons of hay to the acre, and from seventy to eighty bushels of seed. It is sown in the spring, and after harvesting leaves the ground in the finest condition for wheat. Sow thirty to forty pounds to the acre. 10 lbs., $75 \mathrm{c}$.

HUNGARIAN-Sow broadcast at rate of 20 to 30 pounds to the acre. 10 lbs., $85 \mathrm{c}$.

COMMON MULCT-Sow in drills or broadcast from May to last of July. 25 to 30 pounds to the acre. 10 lbs., $65 \mathrm{c}$ NEW SIBERLAN MILLET-Red seeds; earlier and a finer hay than German. Sow 15 to 20 pounds to acre. 10 lbs., 65e.

PEARL MILLET-Grows from 8 to 10 feet high; makes a splendid hay. Sow 3 to 5 pounds to acre. 1 lb., postpaid, 35c. Not prepaid, 10 lbs., $\$ 2.00$; 25 1bs., $\$ 4.00$. Write for prices in larger quantities.

NEW JAPANESE BARNYARD MILLET-Entirely distinct from any other variety. Grows 6 feet high and yields enormously. Has been called "Billion Dollar" grass. Per lb. $25 \mathrm{c}$, postpaid; $1 \mathrm{lb}$., not prepaid, $20 \mathrm{c} ; 10 \mathrm{lbs}$., $\$ 1.50$.

\section{Red Rust Proof or Texas Red Seed Oats}

Very early, rust proof, does well on thin ground and does not lod will bear neglect or a bad season and still make a crop. Originated in Grayson County, 'Texas. Yields enormous crops of heavy golden yellow grain. Our stock is the very finest and grown from pure Texas seed. Pk., 40c; bu. $\$ 1.50 ; 2$ bu., $\$ 2.75 ; 5$ bu., $\$ 6.50$. Sacked free.

IOWA BLACK OATS-1 bu., $\$ 1.50 ; 5$ bu., $\$ 6.50$.

MAMMOTH WHITE RUSSIAN OATS-The big yielding heavy oat that is all kernel. The finest variety for oat meal as it is all meat. You will make no mistak by trying: White Russian Oats. Our price: Pk., 60c; 1 bu., \$2.00; 2 bu., $\$ 5.75 ; 5$ bu., $\$ 8.50$. Sacked free.

\section{Rye}

May be sown in either fall or spring. Makes fine pas10 bu., $\$ 23.00$.

\section{Teosinte}

An Agricultural Wonder-Yielding 100 tons green feed to acre. Resembles Indian Corn, but the leaves are much longer, broader and sweeter. Grows 12 feet high, producing many shoots, thickly covered with heavy foliage. Plant like corn. Over 100 stalks from one seed. Two pounds seed plants an acre. We have the only genuine variety.

OUR PRICES FOR TEOSINTE-Pkt., 5c; oz., 15c; $1 / 41 \mathrm{lb}$., $50 \mathrm{c}$ 1 lb., $\$ 1.25 ; 2$ lbs., $\$ 2.25 ; 10$ lbs., $\$ 10.00$, prepaid. ORDER EARLY.

\section{Pencillaria}

Yields 100 tons Green Feed or 3,000 pounds Seed to Acre. Grows anywhere. Easier to grow than Corn, producing a large amount of fodder at less than 50c a ton. When grown for seed it must have ample space to grow. plants should stand 2 feet apart, in rows 3 feet apart. Cultivate twice. Grows 12 to 14 feet high, averages 40 stalks to each plant. Seed is unequaled for poultry and will ripen in any climate. One pound of seed plants an acre. Reduced prices: $1 \mathrm{oz}$. package, 10c; $1 / 1 \mathrm{~b}$, 1 lb., 50c, postpaid. By express. 5 lbs., \$2.00; 10 lbs., \$3.75; 25 1bs., $\$ 7.50$. Order early; our supply is limited.

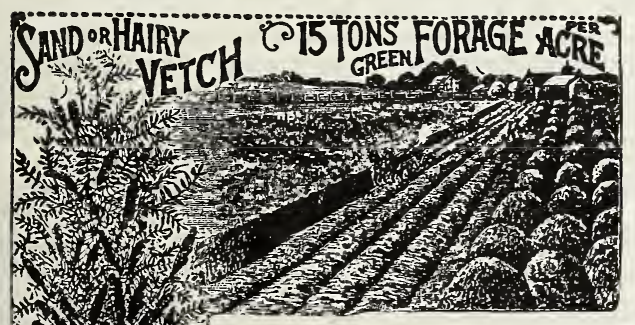

\section{Vetches}

The Wonderful Sand or Hairy Vetches.

(Vicia Villosa)

(See eut). Also called Winter Vetch. This use ful plant is noted for its extreme hardiness and is valuable for forage and fertilizing purposes. It is an annual, but drops its seeds freely and will come up year after year on the same ground. The Depart4. 3 . 4 mates the value of an acre of ment of Agriculture esti1. 2.45 . 1. 1 in August or September covers the ground before winter, and H... prevents washing during winter and early spring. It can prevents washing during winter and early spring. It can also be sown in Apri and will be ready to cut by the middie of July, the second growth affording excellent hog pas10 to 15 tons per acre, equal to 3 or 4 tons when cured as dry hay. Sow in drills, using 30 ors. per acre. Lb., 40 , postpaid. Not prepaid, $10 \mathrm{lbs}$., $\$ 3.50 ; 25 \mathrm{lbs}$. or over, $28 \mathrm{c}$
per $1 \mathrm{~b}$.

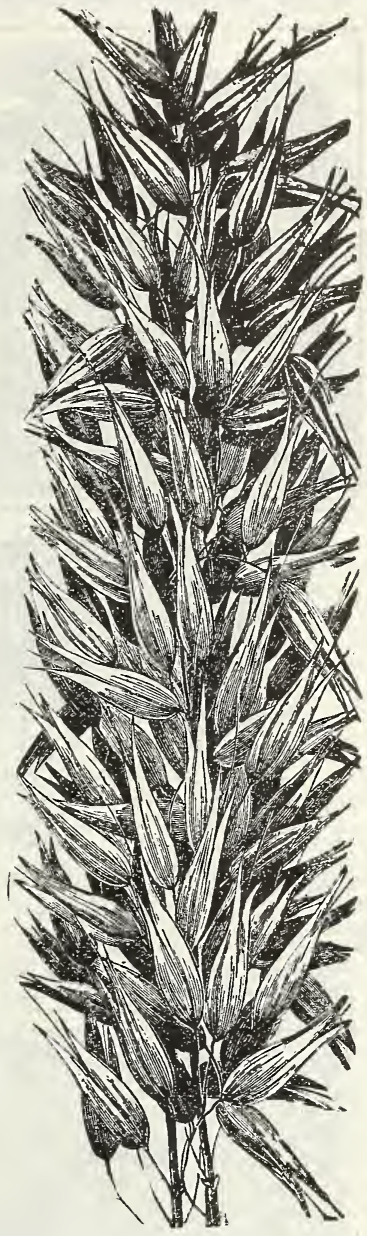

lien Rust Ersof

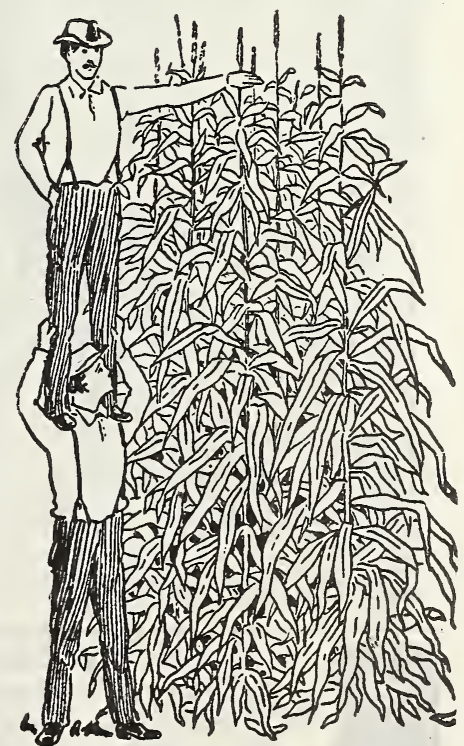

Plant of Pencillaria 


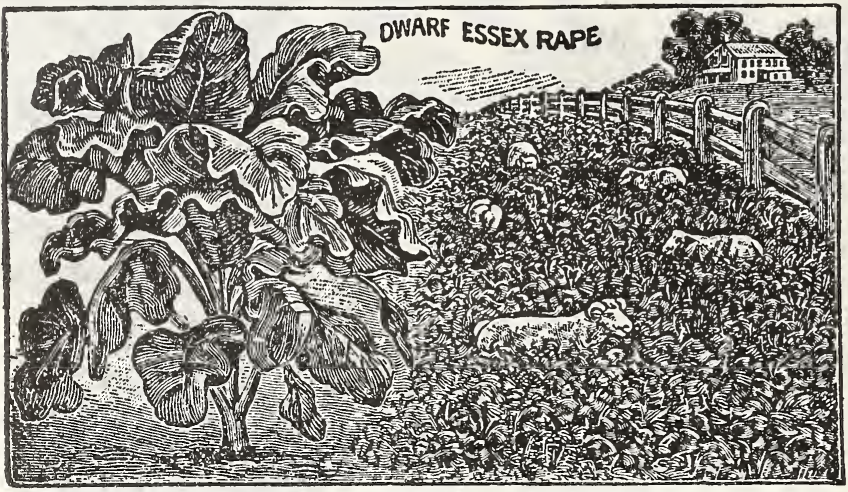

Dwarf Essex Rape

True Stock

The Very Best

Yields Immense Crops

Sow in summer for fall and winter pasture. It is especially good for sheep, but all kinds of stock and chickens are fond of it and do well on it. It comes at the time of year when most needed. It grows best late in the summer or fall and yields an immense amount of feed. Will produce twelve tons of green food per acre. Its nutritive value is twice that of clover. One acre of Rape will furnish pasture for twenty head of sheep for two months. It is good to use as a "catch crop" sown on ground where other crops for some reason have failed, as it grows quickly. Sow 5 pounds to the acre, broadcast. Pkt.. 10c; 1b., 25c, prepaid. Not prepaid, 1

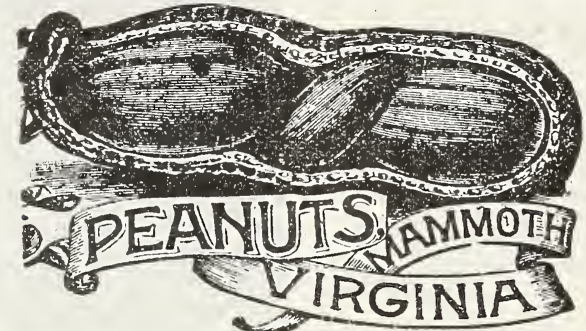

Six or eight quarts of shelled nuts to the acre. The peanut does best in light, sandy soil, tolerably high. They should be planted in rows $3 \frac{1}{2}$ feet apart and 2 feet apart in the row. Drop two or three good peas in each hill, cover about two inclies.

Virginia White-Per lb., 20c; 10 lbs., \$1.75, posśpaid.

Tennesseo Red-Per 1b., 20c; 10 lbs., \$1.75, post paid. Red Spanish-Shelled. per lb., $30 \mathrm{c}$; 3 lbs., 75c. postpaid.
MAMMOTH RUSSIAN

\section{Sunflower 3 Seed}

One of the best egg producing foods lknown for poultry. It can be planted any time until July and will bring a large crop. Just what you need to fill up the vacant spots in your vacant spots in your is not easily cultivated. The flowers are double the size of the double varieties. Lb., 15c; 5 lbs., 65e, postpaid.

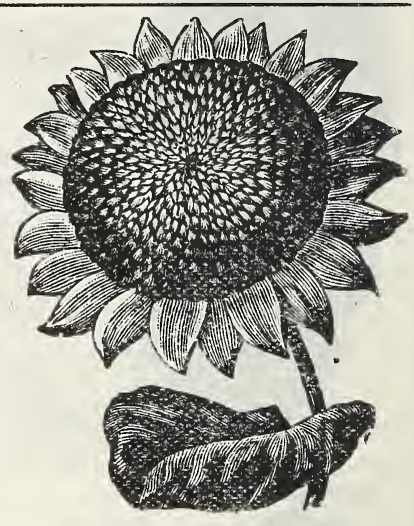

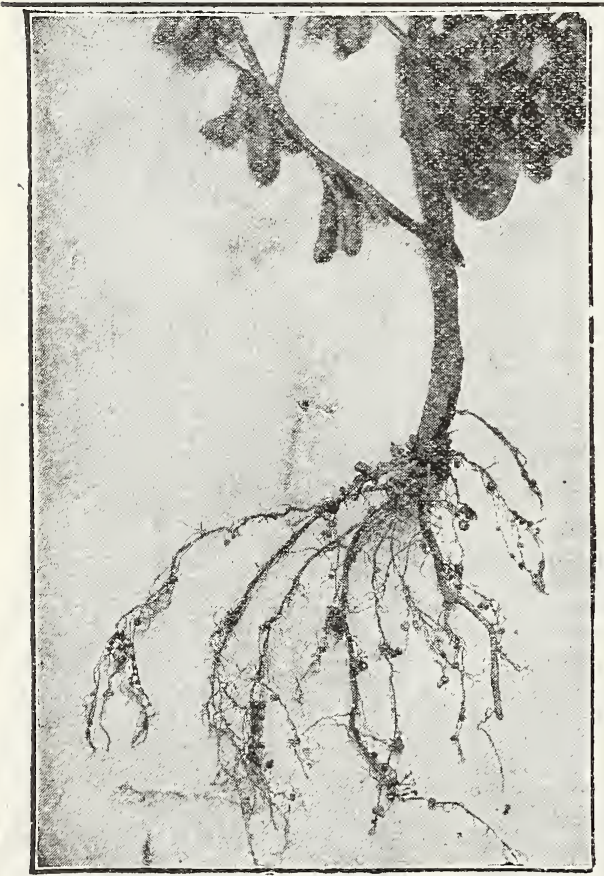

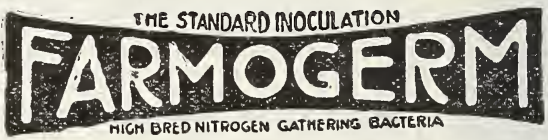

\section{Grow Larger Crops Enrich Your Soil Save Your Largest Fertilizer Bill}

Nitrogen is the most essential element of plant food, the most costly, and the most difficult to retain in the soil. All legumes (clovers, alfalfa, cowpeas, soy beans, peanuts, vetches, etc.), when treated with Farmogerm add nitrogen to the soil. The source of this nitrogen is the air, made available by the activity of Farmogerm bacteria in nodules on the roots of the plant. NO COMMERCIAL NITROGEN IS REQUIRED WHERE FARMOGERM IS PROPERLY APPLIED.

Each-legume requires its particular strain of bacteria. Cowpeas must have cowpea bacteria, soy beans, soy bean bacteria, etc. Farmogerm is prepared for all legumes. Specify what.crop is to be planted when ordering.

Garden size, 50c; 1 acre size, $\$ 2.00 ; 5$ acre size, $\$ 7.50$. Postage or express prepaid. counterpart of the beautiful lawns which have made England the garden spot of the world for ages, by sowing Archias' Evergreen Lawn Grass Seed.

For description and price of Archias' Evergreen Lawn Grass Seed, see page 30, and Inside Cover.

Don't fail to asle for free leaflet on Lawns with your order for Lawn Grass Seed. 
A R CHIA, SEED STORE, SEDALIA, MISSOURI

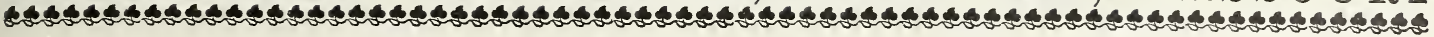

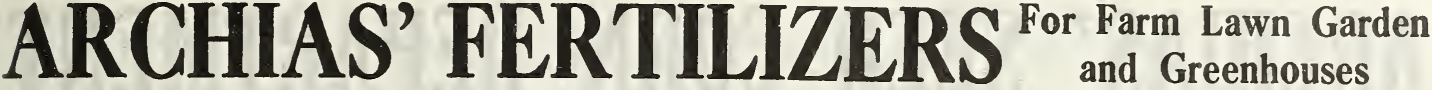

NO LAND IS SO GOOD BUT IT WILL PAY A GOOD PROFIT ON A JUDICIOUS USE OF FERTILIZER.

\section{Try it on Corn This Spring} Try it on Wheat This Fall

Truckers-Our Special Potato and No. 386 Fertilizer will not only increase the quantity, but improves the quality of your crop. Fertilized vegetables mature earlier, which enables you to sell them on the best market.

\section{Ammoniated Dissolved Bone and Potash}

Also called Grain Grower. Guaranteed to contain 2 per cent ammonia, 10 per cent available phosphoric acid and 2 per cent actual potash. It is made by taking correct proportions of bone meal, tankage and sulphate of potash. The most popular fertilizer made for corn, cane, oats, wheat and other grains. 50 1bs., $\$ 1.50 ; 100$ lbs., $\$ 2.75$.

\section{Pure Bone Meal for Roses}

Pot Plants and Lawns-It is ground fine and contains no odor. $1 \mathrm{lb.,} 10 \mathrm{c} ; 10 \mathrm{lbs}$., 45c; $50 \mathrm{lbs}$., $\$ 2.00$; $100 \mathrm{lbs} .$, $\$ 3.50 ; 200$ lbs., $\$ 6.25$.

\section{Fine Ground Beef Bone}

It contains somewhat over 3 per cent ammonia and 50 per cent bone phosphate of lime, in which is $121 / 2$ per cent available phosphoric acid. 50 lbs., \$1.50; 100 lbs., $\$ 2.75 ; 200$ lbs., $\$ 5.25$.

\section{Special Fruit, Vegetable and Tobacco Fertilizer}

This is one of the best for gardeners' use. 50 lbs., $\$ 1.50 ; 100$ lbs., $\$ 2.25$.

\section{Archias' Lawn Fertilizer}

A clean, well-prepared lawn dressing for new or old lawns, etc. It can be applied either in the spring, summer or fall as a top dressing at the rate of 10 pounds for a space $20 \times 20$, or 400 to 500 pounds to the acre. Stable manure for lawns is objectionable in appearance, odor meed seed and cost. Our Lawn Fertilizer overcomes all these and supplies the soil with requisite food for a lux these and supplies the soil with requisite food for a lux-
uriant growth of grass. 10 lbs., 65e; 25 lbs., \$1.25; 50 uriant growth of grass.

\section{Sheep Guano}

Sheep's Head Brand Pulverized Sheep Guano is the ideal dressing for cemetery or private lawns, golf courses or wherever a strong, luxuriant growth of grass is needed. Market gardeners and truckers will find sheep guano extremely profitable to use on all crops. It is especially adapted for use with asparagus, lettuce, tomatoes, cucumbers violets are particularly benefited by its liberal use. 25-1b. bag, 75c; 50-1b. bag, \$1.35; 100-1b., \$2.50. Order a bag for your lawn and garden. Results guaranteed.

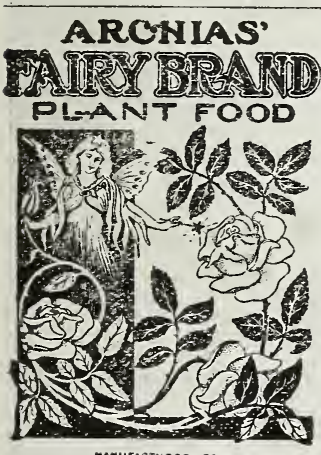

ARCHIAS' SEED STORE CORP

SEDALIA. MO With each package we send free the book, "How to
Make the Window Garden a Success."
Assure house plants a healthy growth, malse them quick flowering, give the foliage a deeper, richer green. It can be used as a top dressing or used in so lution on potted plants, while a pinch in a vase of longer time. Make home beautiful by securing the best results with your plants. Everyone can do so by using Plant Food according to sinple directions on every package.

Use it and your flowers will flourish and their health will last. Small size feeds 25 plants six months, 15c; postpaid, 20c; large size, enough for a year, cut flowers preserves them

\section{Nitrate of Soda}

A fertilizer for all crops. It is very quick in action, and hastens the maturity of crops fully two weeks. Being quickly soluble, it should not be applied until the plants are above ground, when 200 and 300 pounds per acre should be mixed with ground phosphate. Nitrate of soda does not exhaust the land. Lb., 15c; 5 1bs., 65c; 25 lbs., $\$ 2.75 ; 50$ lbs., $\$ 5.00 ; 100$ lbs., $\$ 9.00$. Large quantities, prices on application.

\section{Archias' Japanese Fern Food}

An odorless fertilizer, prepared for ferns, palms and rubber plant. 25c pkg.; postpaid, 40c.

\section{Potting Soil}

Best made and just what you want for repotting plants. Something every lover of flowers needs. Ready to use. Pk., 20c; 1/2 bu., 35c; bu., 60c; 2 bu., \$1.10. Sacked free.

\section{BROADCAST SEEDERS}

The Improved Cyclone Seeder has stood every test of more than forty years' exacting service. It will sow all varieties of farm seed that can be sown broadcast, and with ease to the operator; 5 acres per hour is a fair average for the Cyclone. The seed is distributed evenly and with great saving of time, which makes this a very practical machine on any sized farm. It increases profits both ways-in better crops and in time and seed saved. It will pay for itself in sowing one bushel
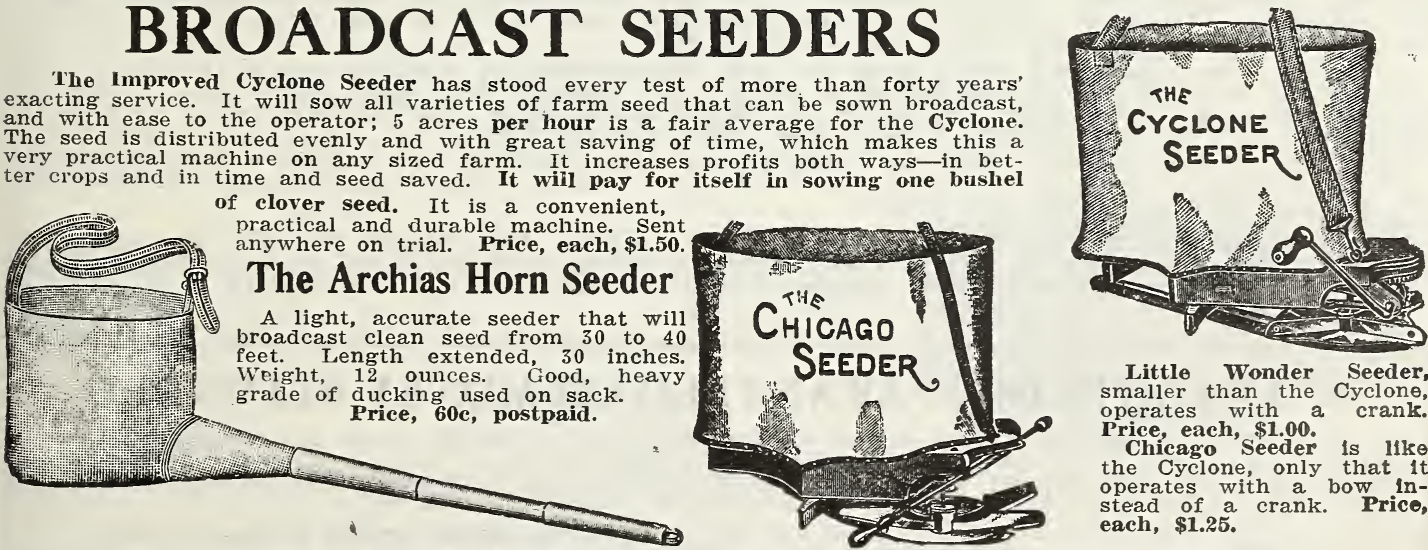

Little Wonder Seeder, smaller than the Cyclone, Price, each, \$1.00.

Chicago Seeder is $11 \mathrm{ke}$ the Cyclone, only that $1 \mathrm{t}$ operates with a bow in each, \$1.25.

Every Seeder Fully Guaranteed by the Manufacturer. BOXED FREE ON CARS HERE. 
GR OW" 'S URE SEE D S," P L A T S A N D TRE E S

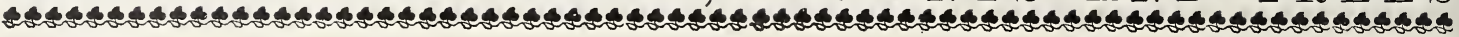
ARCHIAS' SEED CORN DEPARTMENT Grown for Seed, Selected, Graded and Tested A WORD ABOUT OUR SEED CORN

CEED CORN has been our main specialty for years. We spare no expense or pains in producing the highest types of the different varieties we offer. Missouri is noted the world over for good corn, the larg- est average yield per acre and the production of the largest ears. We have the best climate for properly curing seed corn, making the vitality, the germinating properties, higher than any other state in the Union. We have the very best machinery for sorting, shelling and grading, best warehouse for drying and storing seed corn, best method of testing for germinating properties.

The varieties of seed corn we offer are selected with the createst care tried in Missouri and are true to description. Select your variety, send us your order early and you will have your seed on hand when you are ready to plant. By, ordering in advance of the planting season you avoid the rush and a possible disappointment at the last moment. Test your seed corn.

\section{Your Money Back if Not Satisfied}

No single crop is attracting so much attention in Missouri today as Corn. No state in the Union is turning out more high-bred corn than Missouri. No county in Missouri is paying so great attention to breeding good seed corn as Pettis County.

\section{Archias' Golden Mortgage Lifter}

What We Have Claimed for Archias' Golden Mortgage Lifter in Former Years Has Been Verified the Past Season

\section{NO CORN HAS GIVEN BETTER SATISFACTION OR YIELDED BETTER GRAIN THAN THIS JUSTLY GELE- RATED VARIETY}

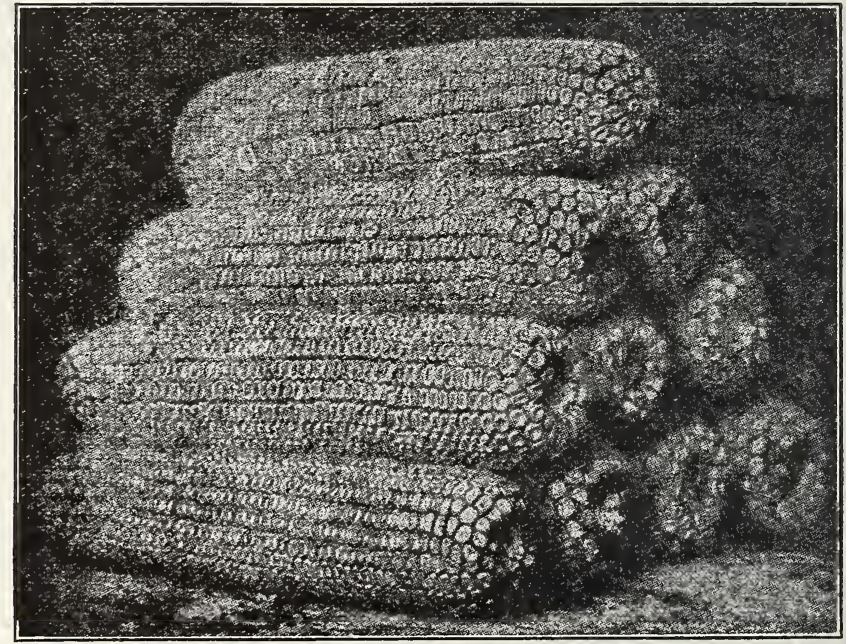

Archias' Golden Mortgage Lifter Corn.

This wonderful variety, first introduced by us in 1893, has gained great favor among the corn growers everywhere. The large amount of corn produced on so small a cob surprises everyone. Our illustration will give you an accurate idea of this wonderful corn.

Archias' Golden Mortgage Lifter is what you have been seeking. It is all corn. It is early. It is prolific. It has strong, stiff stalk and stands up well. It will outyield any other early corn. It has the smallest cob of any large grain. Is rich in oil. It will fatten faster than any corn grown. It suits the grain dealer and tops the market. It takes first prize wherever shown.

The best up-to-date 100-day corn in existence. Its broad, closely-set leaves make it a valuable fodder corn. It will please you, and it's the corn you want. We want every farmer to plant this wonderful corn, and we have put the price in reach of all.

Price of ARCHIAS' GOLDEN MORTGAGE LIFTER, postpaid: Big package, 15c: pint, 30c; quart, 50c. By freight or express, half peck, $\$ 1.25$; one peck, $\$ 2.00$; half bushel, $\$ 3.75$; one bushel, $\$ 7.00$; two bushels, $\$ 13.50$; five bushels, $\$ 32.50$; ten bushels, $\$ 60.00$. Sacked free. Our supply is limited. Order early.

\section{SATISFACTION GUARANTEED OR MONEY REFUNDED}

On arrival of seed corn examine it, test it, have your state or United States Department of Agriculture test it, and if not satisfactory, or if for any reason you do not wish to keep the seed return them within ten days and we will promptly return your money. This guarantee holds good on any seed corn, clover, grass or other seeds purchased of us. Could you ask any fairer offer?

ARCHIAS' SEED STORE CORPORATION. 


\section{Archias' Special Reid's Yellow Dent}

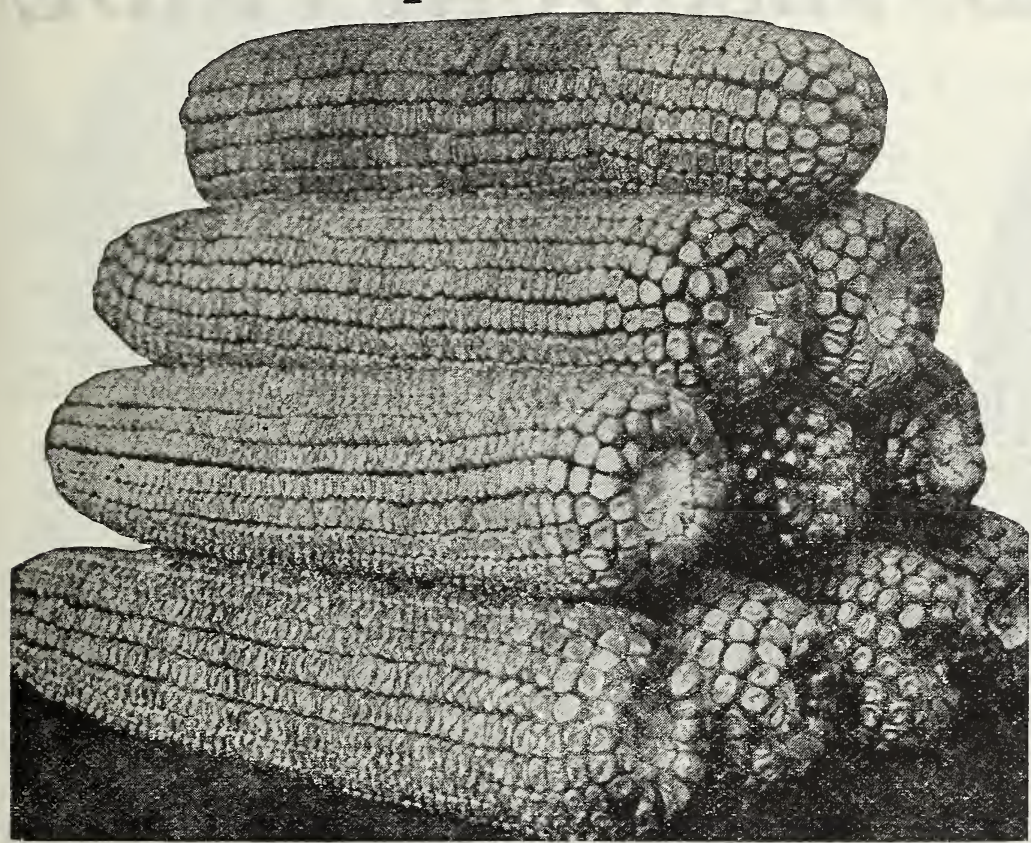

Photograph of Sweepstake Ten Ears Reid's Yellow Dent at Missouri State Corm Show, Columbia, Purchased by Us for Breeding Stock at the Rate of $\$ 275$ Per Bushel.
This is the Highest Type of This Most Popular and Wonderful Variety

Reid's Yellow Dent has won more prizes at the many corn shows and fairs than all others combined. The small cob is completely covered from butt to tip with solid corn, moderately rough kernels, evenly set.

A valuable variety for stock feeders. It is of handsome shape and color and largely grown for exhibiting at fairs, corn shows, and is used in many corn schools as a standard for judging. Our Reid's Yellow Dent was grown from prize-winning stock, and no better can be found. If you wish to win prizes at the fairs do not fail to plant our strain of Reid's Yellow Dent.

Pkt., 10c; lb., 30c; 3 1bs. 75c, postpaid. By freight or express, per qt., 25c; pk., $\$ 1.50$; 1/2 bu., \$2.75; bu., \$5.25; 2 bu., \$10.25; 5 bu., \$25.00; 10 bu., \$48.50. Sacked free. For ear corn, see bottom of page.

\section{GOLDEN CARTNER CORN}

A popular variety among the corn growers of the Missouri Valley. The ear is short and thick, grain deep, with small red cob, easily shelled, and withal an excellent cattle corn, as the cob is not hard. Very prolific. Our growera won first prize at Missouri State Corn Show, Columbia, Mo., last season in "shelling contest." Our stock is pure bu., $\$ 6.50 ; 2$ bu., $\$ 12.50 ; 5$ bu., $\$ 30.00$. Sacked free.

\section{EARLY YELLOW ROSE}

Has made frfends rapidly where known. The stalks grow 8 to 10 feet high, full dark foliage, setting its ears low, usually maturing two good, sound ears 8 to 12 inches long. In a test 70 pounds of ears shelled 64 pounds of corn; matures in 90 to 100 days. By mail, postpaid, 1 lb., 25c. By freight or express, qt., 25c \$25.00. Sacked free.

THE PIRIE-WINNING 100-BUSHELS-TO-THE-ACRF CLASS OF CORN IAISERS LOOK FIRST TO THE

PIROPEIR SELECTION OF SEED CORN. ARCHIAS' "SURE SEED" IS P U R E A N D DEPENDABLE. WHETHEIR GROWN FOIR MARKET OR FOR FEEDING, NO COIRN GROWER WILL MAKE A MISTAKE IN PLANTING SEED FROM ARCHIAS' STOCK. BY ORDEIRING EARLY YOU WILL AVOID POSSIBLE DISAPPOINTMENT BECAUSE OF TREMENDOUS DEMAND ON OUI STOCK AND THE RUSH OF LATE MAND O
ORDERS.

\section{SEED CORN IN THE EAR}

The seed corn we offer on the ear is selected with the greatest care and worth the price we cliarge for it. Our ear corn is packed $70 \mathrm{lbs}$. in a crate, as shown in illustration; only one slat was removed from each crate to better display contents.

\section{Our Prices of Ear Corn}

Archias' Golden Mortgage Lifter.

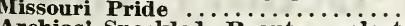

Archias' Speckled Beauty, selected

The following varieties in ear, selected, $\$ 7.00$ per crate:
Improved Leaming
Archias Golden Beauty
Lowa Gold Mine
Iowa Silver Mine
Boone County Whit
Johnson County White

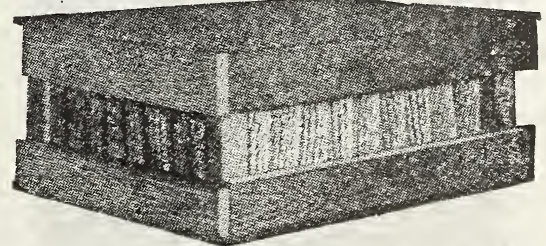

Not less than one bushel crate than shelled corn, and you lose the shrinkage. It will cost you more freight. However, the expense is also greater to us to select, crate and store corn on the cob.

NOTE-Our crates are made solid this season. The corn is carefully wrapped and packed in solid crates, which prevents loss by mice and damage in transit. Our shelled corn is packed in good, new bags, insuring safety in shipping, and should reach you in good order. 


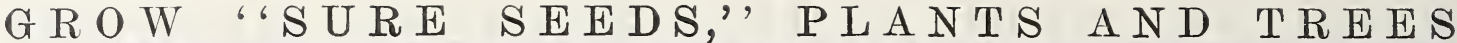

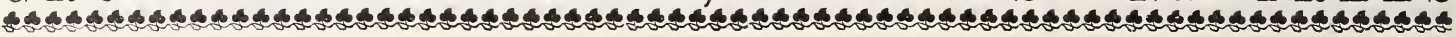
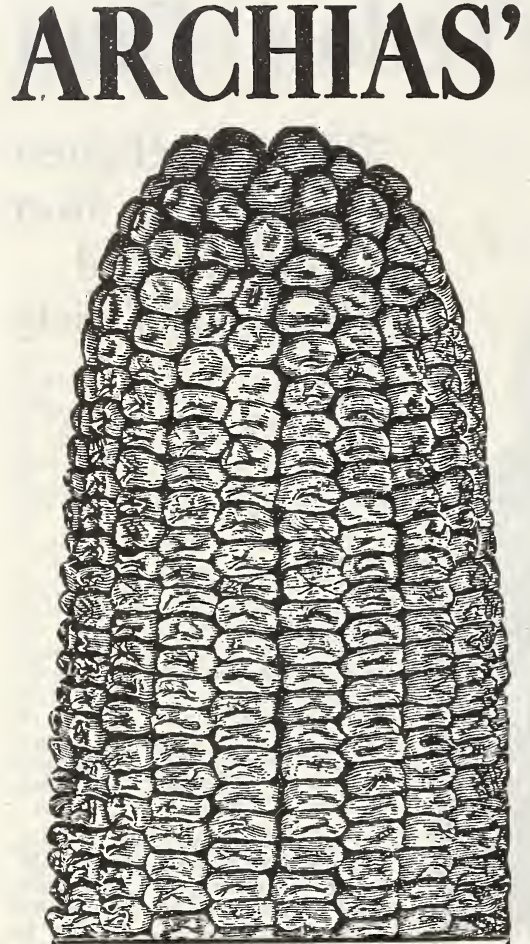

Archias' Missouri

Grown Seed Corn

has become famous over the entire corn belt as ' the most reliable, most prolific and the most satisfactory corn to grow for profit. We exercise the greatest care to have all corn tested before shioping. Plant Archias' Seed Corn. It pays.

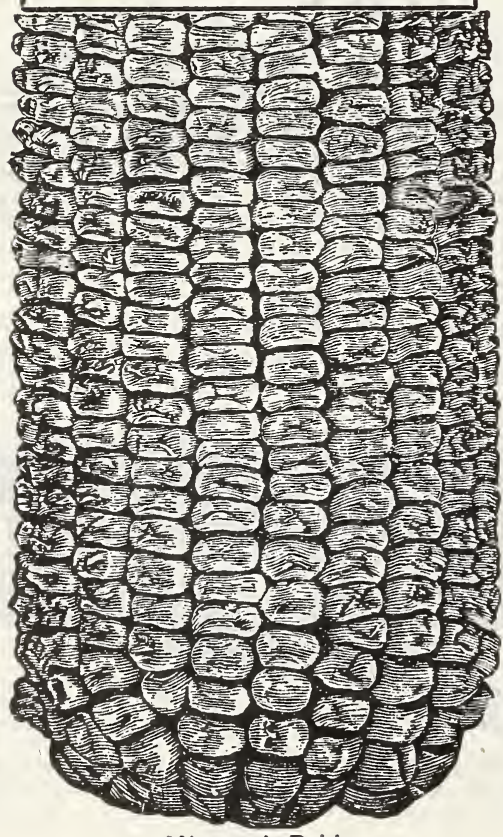

Missourl Pride

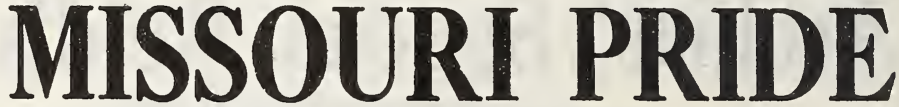

\section{(Yellow)}

A grand, large, medium early, yellow corn of perfect shape, size and color. A wonderful yielder; not quite as early as the Iowa Gold Mine but larger and more prolific, consequently more profitable.

Ears measure 9 to 11 inches in length, $71 \%$ to $81 \%$ inches in circumference, with very deep grain, set firmly on the cob; cob small for size of grain, 16 to 20 rows of kernels on cob. Medium size stalk, solid, with plenty of foliage.

An all round profitable corn for the farmer, whether grown for market or for feeding. No corn grower. will make a mistake in planting Archias' Missouri. Pride. As our stock is limited would advise ordering early. Price of Archias' MIssouri Pride, per packet, $10 \mathrm{c}$; per pound, by mail, prepaid, $30 \mathrm{c}$. By express or freight, 1 qt., 30 ; 4 qts., $\$ 1.00$; peck, $\$ 1.75$; $1 / 2$ bu., $\$ 3.25$; bu., $\$ 6.25 ; 2$ bu., $\$ 12.25$. Sacked free.

\section{Improved Leaming}

A quick growing yellow variety, highly esteemed by those who have grown it. It usually produces two ears to the stalk. It is one of the seven varieties recognized by the Illinois Experiment Station, where it has been first in yield more times than any other variety. The Improved Leaming has been selected for a richer color - a beautiful brownish yellow-a deeper and somewhat rougher kernel. The ears average about 10 inches long and weigh three-fourths to one pound each - The stalks are of medium height, with many broad leaves, making it one of the best sorts of ensilage and fodder. Numerous tests at the experiment station show it high in protein and oil content, making it valuable to the live stock grower and feeder. By mail postpaid, Ib., 25c; 3 lbs., 60c. By freight or express, qt., 25c; pk., $\$ 1.50 ; 1 / 2$ bu., $\$ 2.75 ; 1$ bu., $\$ 5.25 ; 2$ bu., $\$ 10.25 ; 5$ bu., $\$ 25.00$. Sack. ed free.

\section{Iowa Gold Mine Corn}

A popular Yellow Dent corn, originated in Iowa. This corn, since its introduction a few years since, has attained wide popularity. The ears are of good size and shape, and of a bright, golden yellow color, has very long grains and small red cob; matures in about 95 days and has given fine satisfaction throughout the corn belt. Our seed was grown from direct headquarters' stock. By mail, postpaid, 1 lb., 25c. By freight or express, qt., 25c; pk., $\$ 1.50 ; 1$ bu., $\$ 5.25$; 2 bu., $\$ 10.25 ; 5$ bu., $\$ 25.00$.

\section{Legal Tender Yellow Dent}

It is one of the best main crop Yellow Dent we have, being large and deep grained. It yields immensely, ears 10 to 12 inches long: grains $3 / 4$ to $5 / 8$ inch in length, and run well up to 20 rows on the ear. They have a glossy orange yellow body, with a lemon yellow cap; a load of Legal Tender is a thing of beauty. Try a bag of it. 'By $1 / 2$ bu., $\$ 2.75 ; 1$ bu., $\$ 5.25 ; 2$ bu., $\$ 10.25 ; 5$ bu., $\$ 25.00$. Sacked free.

\section{Archias' Golden Beauty Corn}

For general planting in this section we know of no corn that will give better satisfaction than the big, handsome, Golden Beauty. It is the largest grained and finest corn in appearance we have ever seen. The ears are of perfect shape, as shown in cut, which was made from a photograph of an average ear. - The cob is so small and the grain so large and broad that a single grain will almost cover the end of the cob when broken in half. It is of a beautiful golden yellow color and of fine quality for grinding. It matures in about 110 days and yields big crops. We recommend the Golden Beauty as the handsomest and largest grained corn in cultivation, and is sure to please every farmer who grows it. By mall, per Ib., 25c; 3 Ibs. 60 c. By express or freight, per peck, $\$ 1.50 ; 1 / 2$ bu., $\$ 2.75 ; 1$ bu., $\$ 5.25 ; 2$ bu., $\$ 10.25 ; 5$ bu., $\$ 25.00$. Bags free. 


\section{Archias' Selected-POP CORN-That Pops}

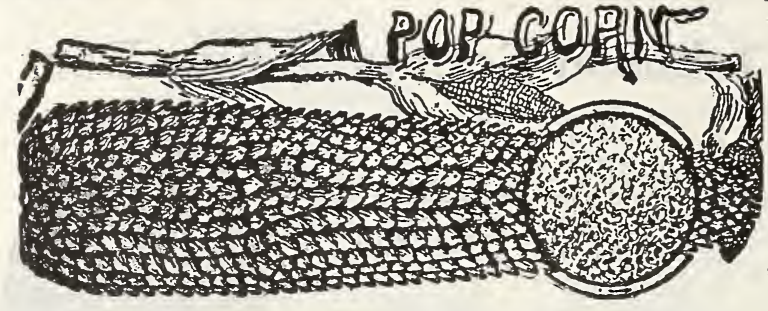

It pays to raise pop corn as a general crop. Demand usually exceeds the supply, and pays 3 to 4 times the amount per acre. For main crop the Monarch White Rice and Golden Seal will bring the best prices; they are better known. Let the children try a small patch, anyway, for home use. Ask for prices in quantity.

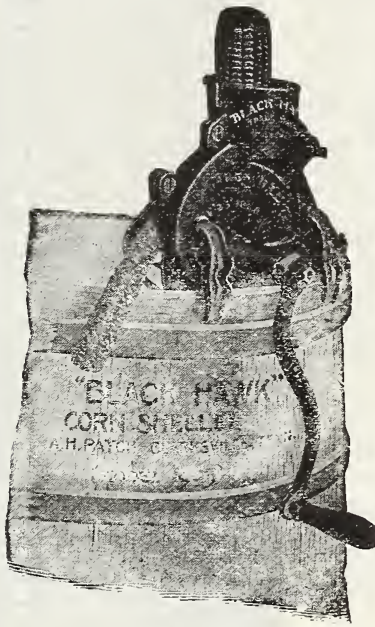

\section{Black Hawk Corn Sheller}

Recommends itself, simple, strong, durable, and is age under fair treatment. Weight, 14 lbs. Our price

\section{Only}

\section{$\$ 2.50$ Each}

\section{Model Grinding Mill}

Monarch White Rice-It is the best white variety. 1bs. per acre. It will pay you to try it. Pkt., pt., 25c; qt., 45c. By express, 1/2 pk., 75c; pk., $\$ 1.25$.

Archias' Golden Seal-A new yellow pop corn that is ahead of all others and commands the highest price on our market. Plant this for profit. Postpaid, pkt., 5c; pt., 25c; qt., 45c. Not postpaid, qt., 35c; 4 qts., $95 \mathrm{c}$; pk., \$1.50.

Japanese Dwarf Rice-Very tender and almost hulless. Ears short and chunky. Heavy yielder. Pkt., $15 \mathrm{c}$; pt., 35c; qt., 60c, postpaid.

Queen's Golden-Stalks grow 6 feet high, and the large ears are produced in abundance. A single kernel will expand to a diameter of one inch. Pkt., 5c; pt., 25c; qt., 45c; three select ears, 15c, postpaid. Not postpaid, qt., $25 \mathrm{c} ; 4$ qts., 90c; pk., \$1.50.

White Pearl-Our common market variety. Pkt., 5c; pt., 35c; three select ears, 10c, postpaid. Not postpaid, qt., 35c; 4 qts., 85c; pk., \$1.40.

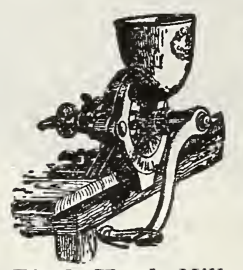

Black Hawk Grist Mill

A hand mill for country, village and city housekeepers. Fresh corn meal, graham and rye flour, etc. ast, easy grinder; made to last. paid.

Soon pays for itself. You will find a dozen uses for it. Grinds corn, wheat, rye, spices, coffee, etc., fine ing grain for poultry. Black Hawk Black Hawk Mill

An improved hand power grinding mill of new and elegant design, compactly made of strong and durable metal. They are easily adjusted to grind fine or coarse, all kinds of grain, dry bone, shells, roots, bark, salt, feed for chickens and animals. Also for corn meal and Graham flour. These mills are warranted to grind more rapidly and outlast any mill of this class on the market.

No. $1 \frac{1}{2}$-Weight, 20 lbs.; capacity, 1 bu. per hour.......\$ 3.25 No. 2 -Weight, 35 lbs.; capacity, $11 / 2$ bu. per hour.......... 5.25 No. 3 -Weight, 63 lbs.; capacity, 2 bu. per hour....... 7.50 No. 4 - Hand and Power Mill, with pulley Boxed and delivered on cars here. Write for descriptive circular free.

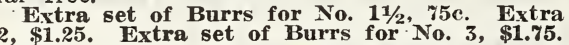

Table Showing the Amount of Seed Necessary for an Acre, and Number of Pounds to the Bishel. No. lbs No. lbs.

Red Clover

White Dutch Clover

Alfalfa

$\begin{array}{cc}\text { to bu. to acre } \\ 60 & 10 \text { to } 15\end{array}$

Esparsette

Alsyke Clover

Timothy

Hungarian

Millet

Red Top ...........

Orchard Grass

Kentucky Blue

$\begin{array}{rrr}60 & 10 \text { to } 15 \\ 60 & 5 \text { to } 8 \\ 60 & 20 \text { to } 30 \\ 24 & 40 \text { to } 45 \\ 60 & 5 \text { to } 8 \\ 45 & 10 \text { to } 15 \\ 48 & 24 \text { to } 36 \\ 50 & 25 \text { to } 50 \\ 14 & 14 \text { to } 20 \\ 14 & 14 \text { to } 28 \\ 14 & 28 \text { to } 42 \\ 25 & 25 \text { to } 50\end{array}$

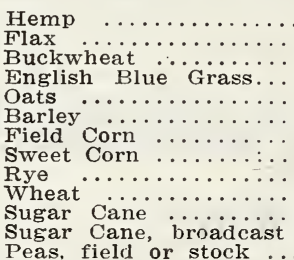

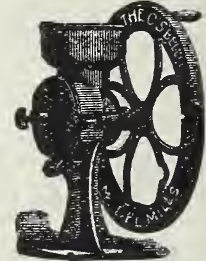

Model Grinding Mill

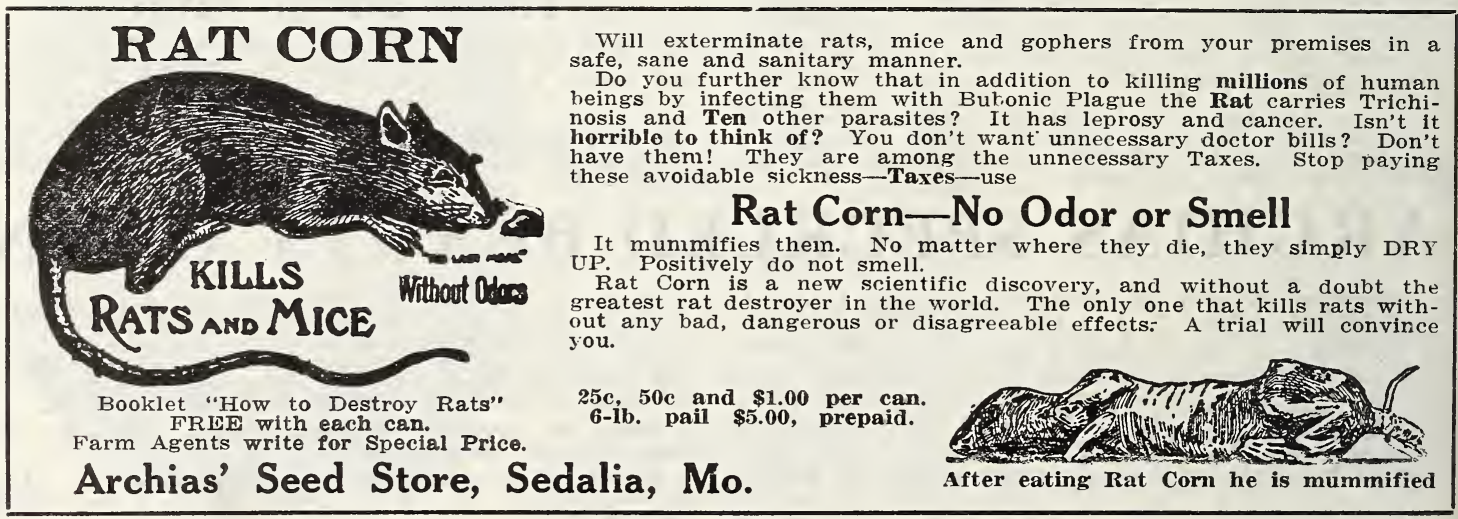


A R C I A S , SEED STORE, SEDALIA, MISSOURI

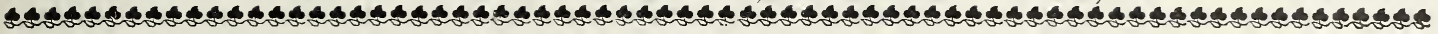
Archias' Selected Flower Seeds

Containing the most popular varieties and choicest strains from the best growers in America and Europe-Adapted for cultivation in the conservatory, greenhouse and garden-Our seeds are fresh and germinate readily. Discounts on Flower Seeds For 25c select flower seeds to the amount of $35 \mathrm{c}$.
For 50c select flower seeds to the amount of $75 \mathrm{c}$. For $\$ 2.00$ select to the amount of $\$ 3.00$.
For $\$ 1.00$ select to the amount of $\$ 1.50$. All flower seeds sent free by mail on receipt of price.

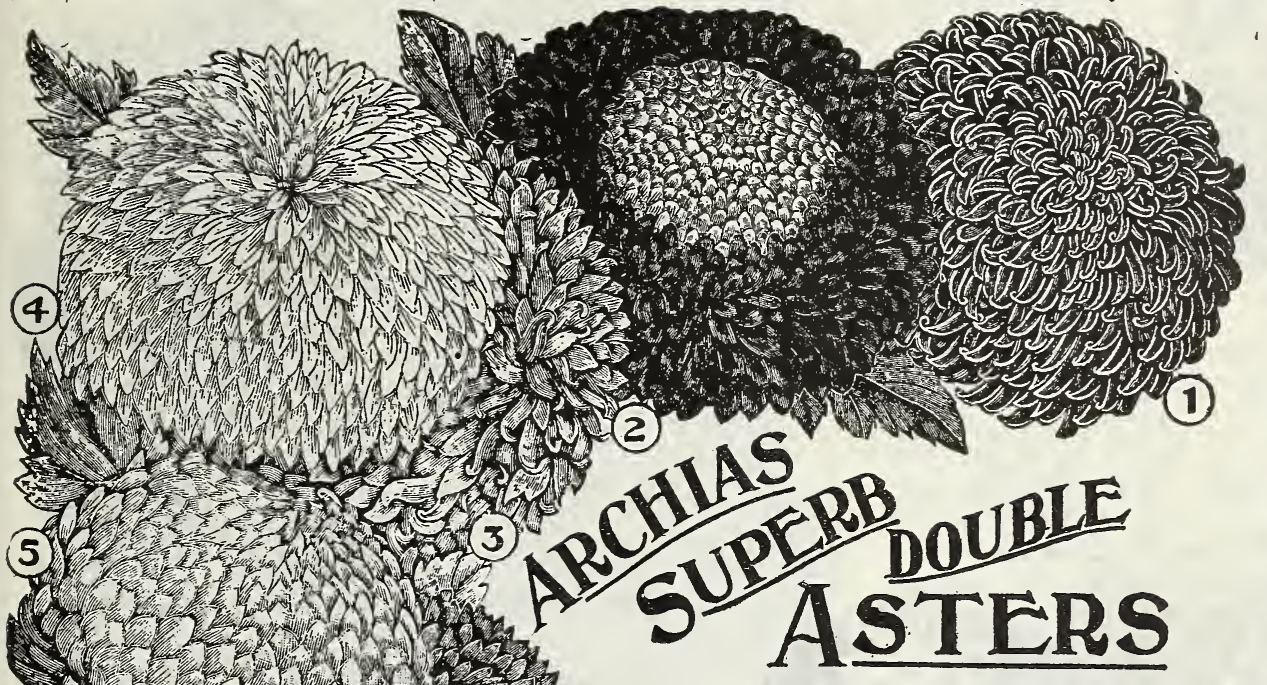

These diswe think, extremely 1 i be $\mathrm{r}$ in $\mathrm{g}$ th $\mathrm{e}$ qualit $\mathrm{y}$ of seeds we send out. No one lot of flowers.

The aster as a cut flower Ch r s $t h$ e $m$ u m in beauty of or, and re$\mathrm{m}$ a in $\mathrm{s}$ firm and fresh for d a y s. They grown, very are in bloom at a $t$ im e garden favorites are gone.

IX TYPES OF ASTERS-ONE-THIRD ACTUAL SIZE. CREMM OF THE ASTER FAMILY.

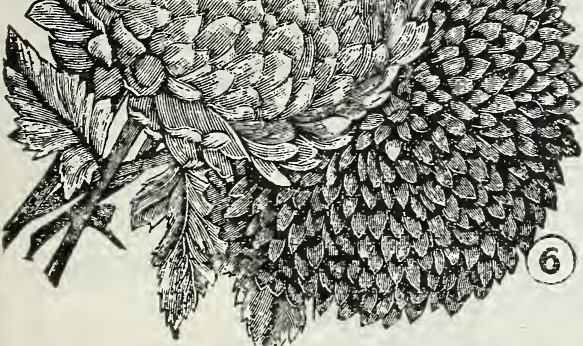

OTEN OF THE MARK WT

A class of asters characterized by extreme earlines and the profusion of their flowers. Plants average 1 large flowers. Pkt., 5c; 1/4 oz., 20c; oz., 60c.

(3)-ARCHIAS' NEW VTCTORIA-PRIZE STRAIN A very free bloomer. Flowers very large, petals in Plant of fine pyramidial form. about 18 inches hion. Nixed colors, plit.. 10c: 1/8 oz., 20c; 1/4 oz., 35c.

(-) -ARCHLAS, WHTE BIRANCHUNG UPRIGHT

The flowers are large, pure white, borne on long stems and excellent for cutting. Height 2 feet. Pkt., 10c; 1/8 oz., 15c; 1/4 oz., 25c.

(5)-ARCHIAS' PEONY FLOWERING PERETCTION Certainly one of the most perfect and deservedly popular asters. Very double, large and beautiful. Height 18 inches. Mixed, pkt. 10c; 1/8 oz., 15c.

(6)-SENPLE'S GIANT BRANCHUNG ASTERS A fine American strain, producing handsome double
flowers on long stems. Pkt., 10c; 1/8 oz., 15c; 1/4 oz., 25c.
These beautiful flowers are very popular and profuse bloomers. ur seed is of the very finest that can be produced. We recommend our customers to plant several varieties, as all are satisfacthroughout the summer and fall.

\section{(1)-ARCHIAS' GIANT BIRANCHING ASTERS}

new strain of late flowering asters, which bears on perfectly formed double flowers 4 inches in diameter

, pkt., 10c; 1/8 oz., 15c; 1/4 Oz., 25c; 1 oz.,

rchias' Giant Branching Rich Crimson. Pkt., 10e.

Archias Giant Branching Lavender. Pkt., 10c.

Archias, Giant Branching Royal Purple. Pkt., 10c.

pkt. each of the 4 Giant Branching Asters for only $30 \mathrm{c}$

Mixed Colors-Above shades and many others. Pkt. $100 ; 1 / 8$ oro

SPECIAL OFFER-Your Choice of any two packages above six superb Asters, 15c, or 4 packages, 25c. Packet ach of the above six varieties for only $\mathbf{3 5 c}$.

\section{ARCHIAS' GIANT COMET ASTERS}

Fxtremely floriferous. Fifteen inches; early blooming and quite distinct from all others. The double flowers are sometimes four to five inches across, with long, wavy Mixed Colors-1.ach, 10c per plt.; 1/8 oz., 20c; 1/4 oz., 30c; $11 / 2$ oz., 50c.

\section{HARDY ALPLNE ASTERS}

Sow the seed early, and they will bloom profusely during the entire fall and make plants that will bear hundreds and perfectly hardy. The flowers are large and very bright and beautiful; many are deep blue, with yellow center. This is a very superior mixture
Daybreak Aster-This superb aster is one of the rare gems that have come to stay; color a delicate sea-shell pink; flowers are round, very large and full, borne upright on long, stiff stems. Pkt., 10c.

Lavender Gem Asters-One of the most beautiful as ters; color a charming shade of lavender, deepening with age. The flower is always full double, borne in profusion on long, slender stems. Of the ostrich feather type; large, artistic and loosely arranged. Pkt., 10c.

Purity Aster-A snowy-white aster, similar to Daybreak, except in color. The plants are very neat, of medium height, and are literally covered with a mass of flowers like snowballs. Pkt., 10c.

Lady Roosevelt-One of the finest of recent introduction; perfect in shape; color a magnificent ros rior. Our seed comes from the originator, and is of finest quality. Midseason. Pkt., 15c.

Violet King Aster-The peer of the grandest chrys anthemum. A new type and color in asters. The other variety; petals resemble the quilled sorts, but are much larger and broader, those in the center, twisted, curled and incurved, completely covering the round, full and very large, many of the flowers meas uring from four to five inches in diameter. Its color is soft violet-lilac. Pkt., 10c.

SPECIAL OFFER-One packet each of the five new asters, Daybreak, Lavender Gem, Purity, Lady Ioosevelt and Violet King, for only 35c; 2 collections for 65c. 
GROW "SURE SEEDS," PLANTS A N T T RES

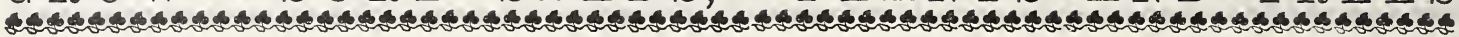

\section{Alyssum (Mad Wort)}

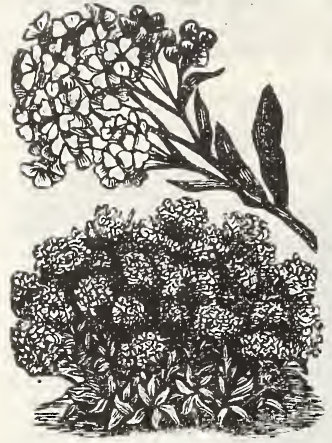

Alyssum or cutting. $25 \mathrm{c} ;$ oz., $40 \mathrm{c}$.
One of the sweet scented flowers that is always in every garden. An easily grown ar. nual; fine for beds, edging, or

Little Gem, or "Carpet of Snow"-A dwarf, very compact growing variety, that, while only 6 inches in height, each plant will carpet a circle from 20 to 30 inches in diameter. From early summer until very late autumn the plants are a late autumn the plants are a flowers of delicious fragrance. Pkt., 5c; 1/4 oz., 15c; $1 / 2$ oz.

Sweet Alyssum-White, larger than Little Gem. Blooms continuously from earliest sum mer until hard frosts. (See 15e; oz., 25e.

\section{Arbonia}

Umbrellata-A Verbena-like plant bearing rose-colored, fragrant flowers. Splendidly adapted for rock work; height, 8 inches. Pkt., 5c.

\section{AGERATUM}

Excellent for cut flowers and fine for large beds in summer, and as pot plants for winter. Height, 2 feet.

Mexicanum - Light blue 10 o

Finest colors, mixed, $1 /$ oz., 10c; 1 oz., 25c.

AMARANTHUS

Tri-Color, Joseph's Coat, 5c pkt.

Salieifolins Fountain Plant,
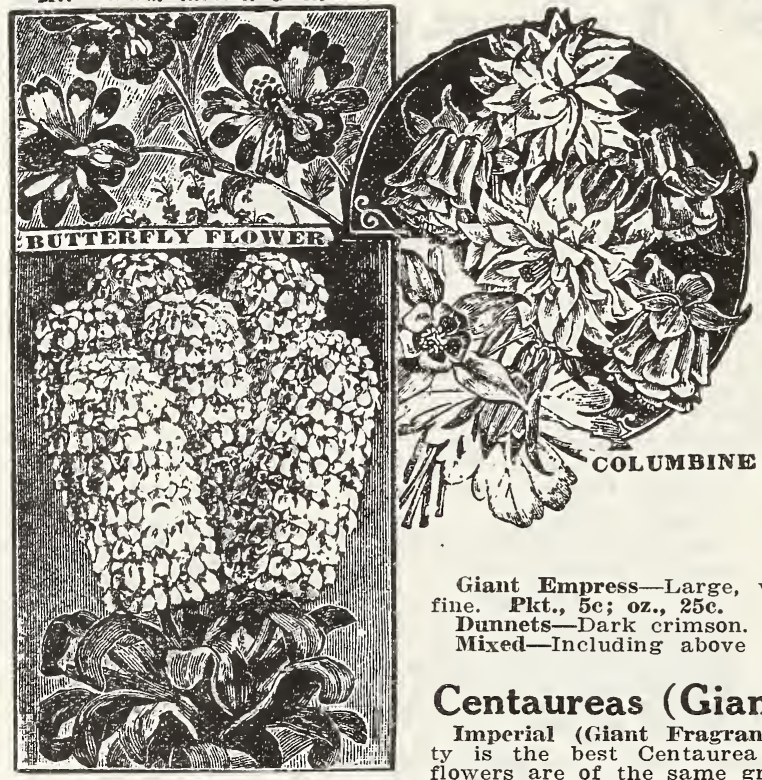

Giant Empress-Large,

Plit., 5c; oz., 25c.

Dunnets-Dark crimson.

\section{Centaureas (Giant Sweet Sultan)}

Imperial (Giant Fragrant)-This new variety is the best Centaurea now offered. The tawrea Marguerite, but larger in size and much easier grown; blooms in great abundance from July until frost; highly fragrant. Centamrea Imperialis-White, Brilliant Rose, Purple and Lilac

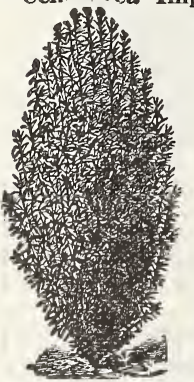
Either of the above Centaureas, pkt., 5c, or the set of four

Bachelor's Button (Centaurea Cyanus)-One strain of this splendid annual is especially fine. The true old-fashioned Bachelor's Buttons of your grandmother's garden. Finest mixed colors. Pikt., 5c; 1/2 oz., 10c; oz., 15c.

Centaurea

\section{Burning Bush or Summer Cypress \\ (Kochia Tricophylla)}

nly in spring, soon forms a cypress-like hedge of the most lively green and of perect symmetry; by midsummer it attains a height of about 3 a deep red; a splendid plant to divide the vegetable from the flower garden, or for forming a hedge for the summer for any

Burnugg Bush purpose. Plkt., 10c.

\section{Butterfly Flower}

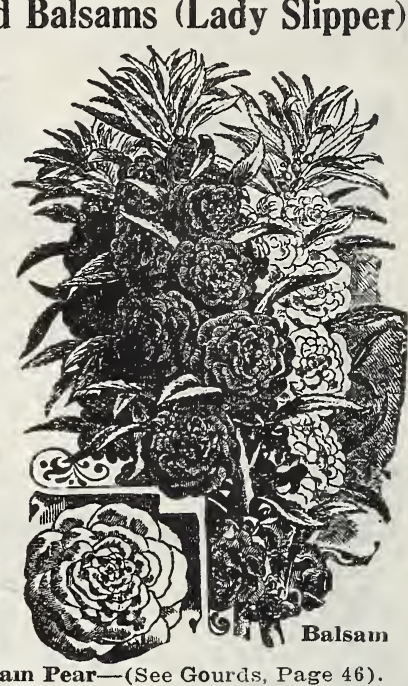

ight colored flowers, use easily cultivated, pretty, , producing thousands of pretty butterly flowhardy annuals; 2 to 3 feet. Mixed, 5c.

\section{Columbine (Aquilegia)}

Exceedingly showy, early blooming, hardy plants; spurred flowers, and of easiest culture. The long roy perennial, $1 \frac{1 / 2}{2}$ to 2 feet. Mixed-All the best sorts and col-

\section{Candytuft}

Aseful plant or the easiest culture, . Sow early in spring 6 inches apart

resembling white hyacinths. Very $5 \mathrm{c} ; 0 \mathrm{z}, 25 \mathrm{c}$

others. Plit., 5c; oz., 20c.

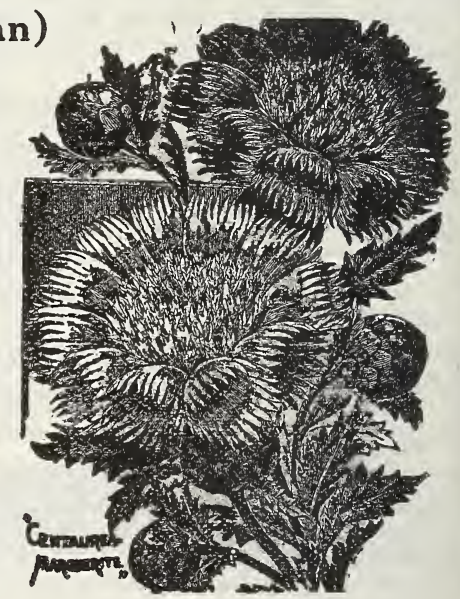


A R C IA S , SEED STORE, SEDALIA, MIS OURI

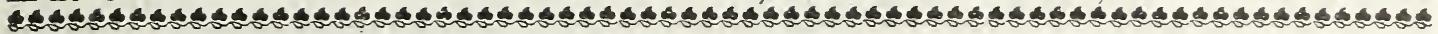
ARCHIAS' Hardy:Carnations and Dianthus Pinks

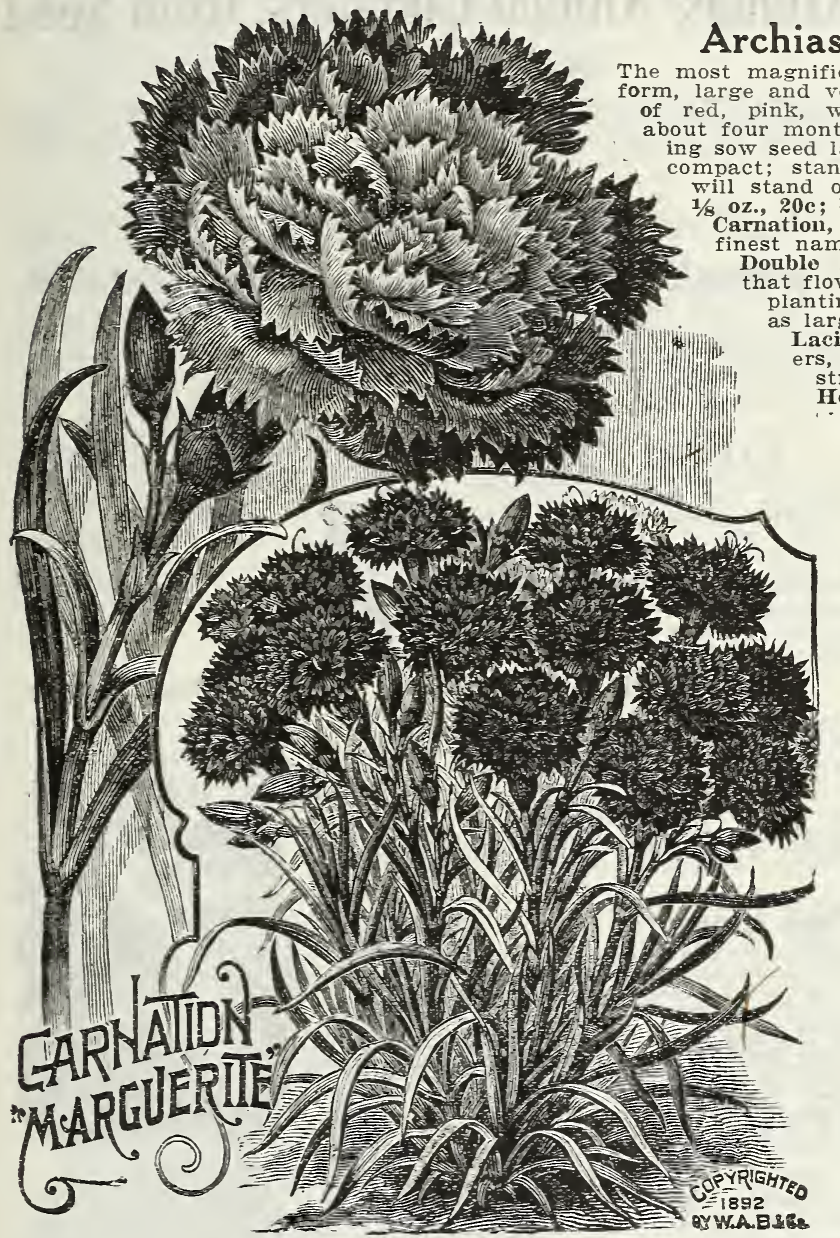

Calliopsis or Coreopsis

One of the earliest trown annual flowers; effect anywhere. Sow the seed thinly late in spring. Fine for cut flowers. One to two feet.

Mixed Tall Sorts-All choice sorts are included. Pkt., 5c; oz., 20c.

Mixed Drrarf Sorts-Extra fine for bedding. Pkt., 5c; oz., 25c.

Golden Ware Drummondii-Bushy, compact plants; bright golden yellow flowers; dark brown centers. Pkt., 5c; 1/4 oz., 10c.

Lanceoiata Grandiflora-Grandest perennial plants. Splendid in masses or as cut
oz., 20c; oz., $60 \mathrm{c}$.

\section{Castor Beans}

Stately, strong-growing plants, with very ornamental foliage, well adapted as center plants of groups of cannas, dahlias, etc. 5c; oz. 15c; 2 ozs. $25 \mathrm{c}$

Castor Beans-Nixed sorts. Pkt., 5c; oz., 10c; lb., 70c.

\section{Canterbury Bells}

\section{(Campanula)}

This old-fashioned flower is a favorite with all. Stately and howy, and of the earliest growth. Hardy biennials.

Calycanthema "Cup and Saucer"-Our mixture includes all the best colors and varieties. Pkt., 10c.

Finest Donble Mixed, pkt., 5c.

Finest Single Mixed, pkt., 5

Archias' Prize Mixture-An elegant mixture of all the finest classes and colors of single and double and "Cup and Saucer" varietles. Pkt., 10c; 2 pkts., 15c.

\section{Archias' Mammoth Cosmos}

This is a popular plant and a bloomer. Both foliage and flowers are beautiful for bouquets and vases. Flowers double the size of the old. Large flowering petals are large overlapping, forming perfectly round flowers, deeply ribbed and of good substance. Mixed colors. Pkt., 5c; 1/2 oz., 10c; oz., 20c.

\section{Hardy Perennial or Clove Pinks}

Adapted for beds and borders; sweet scented. hould be in all gardens.

(Plumarius Flore Pleno) hardy varieties having double and semi-double Pkt.,

\section{Single Annual Pinks}

Hedgewigii, Mixed-Flowers three Inches

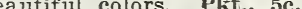

China-Single, mixed. Pkt., 5c. 5 . Flowers of a beacifer-Double fringed pinks. Finterer 2 1nches across, on long stems, which makes it very valuable for cutting. Plant grows about 12 to 15 inches high. A fine bedder. Pkt., 10c; 3 pkts., 25c.

Archias' Special Mixture-Of single Dianthus Pinks, of easy culture. Pkt., 5c; $1 / 4$ oz., 25c; 1/2 oz., 40c; 1 oz., \%5c.

Archias' Mixture of Double Pinks-This splendid mixture is a blended combination of all the double varieties, including the

Calendula (Pot Marigold)

One of the easiest grown and brilliantly showy, free-flowering, hardy annuals; bloom Fine Double Irixed-Contains the choicest

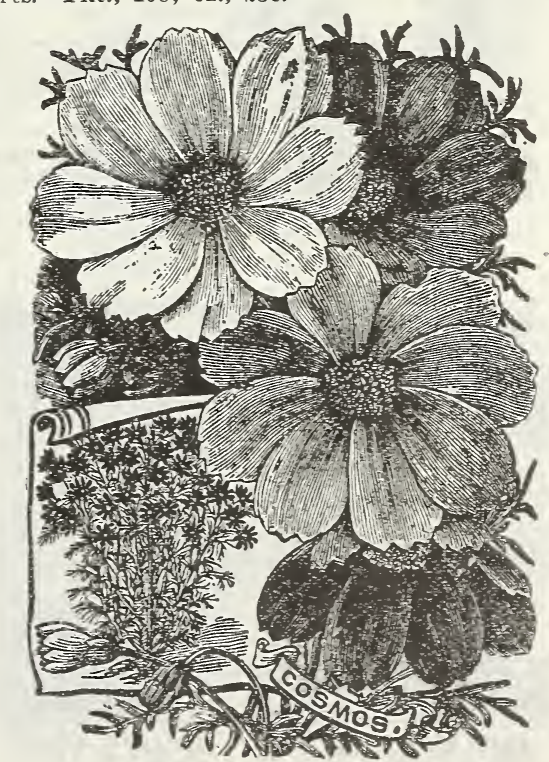


GROW "SURE SEEDS,' PLA N T A N D TREES

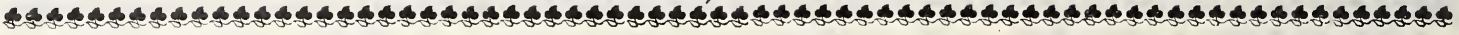

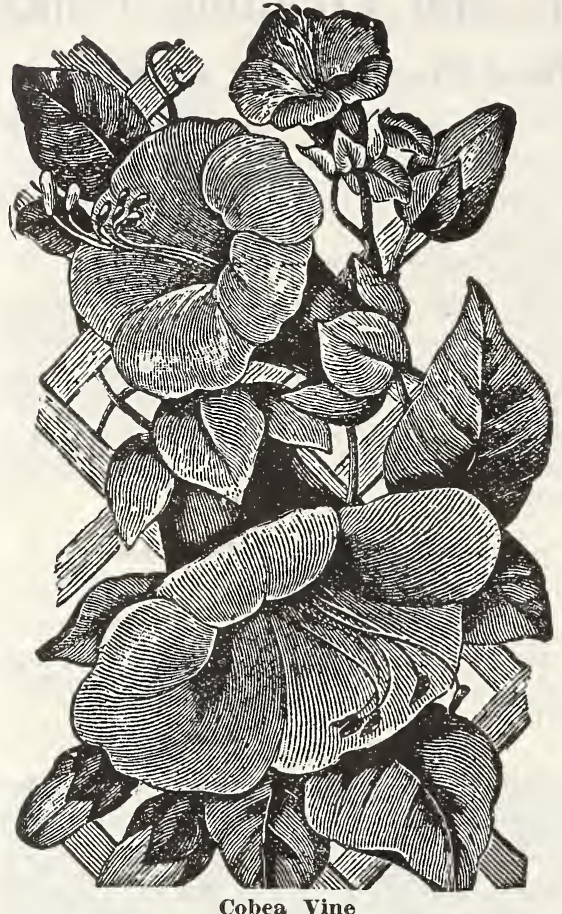

Cobea Vine

\section{Archias' Annual Climbers, from Seed}

\section{Adlumia Cirhose}

Allegheny Vine or Mountain Fringe-Beautiful, hardy biennial climber, flowering the first season; clusters of small, rosy-like flowers and green feathery foliage. Comes up yearly from self-grown seed. Climbs 15 feet. Pkt., 10c.

\section{Balloon Vine}

A rapid and graceful climber. Flowers resemble small balloons.

Cardinal Climber (Ipomea Quamoclit Hybrida)

The finest new annual climber introduced in many years. Very gracul and rowing rapidy, and in a warm, sunny location in deciniated palm-like, rich green leaves, bespangled with elusters of fiery scarlet, tubular, spear-shaped flowers, measuring $1 \frac{1 / 4}{4}$ ; oz., 25c.

\section{The African Pipe Gourd}

A luxuriant, rapid-growing annual climber, adaptable to all purposes for which climbIng plants are used, and besides, it produces the ornamental gourds from which are made

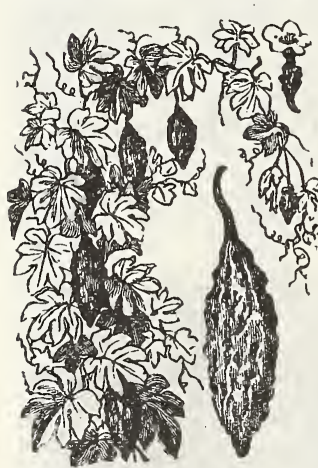

Balsam Apple

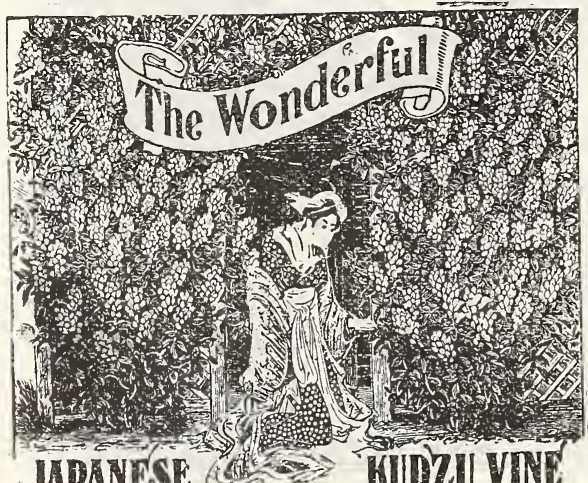
the African Calabash pipes, now so popular on account of their lightness, grace and meerschaum coloring qualities. When grown for the production of pipe gourds, the vines are usually allowed to grow on the ground like cucumbers, pumpkins, etc., so that the fruits in place of hanging down and growing straight, will take their natural pipe curve. Pkt., 15e; 2 plts., 25c.

Hercules Club-Grows six feet long. Pkt., 5c.

Sugar Trough--Often used for buckets. Pkt., 5c.

Dish Cloth of Chinese Sponge (Luffa)-(Dish-rag Gourd). 'The fibrous interior can be used as a sponge.
Pkt., 10c.

Japanese Nest Egg-White egg-like fruits. Pkt., 5c. Dipper Gourd-Used for dippers. Pkt., 5c.

Ornamental Pomegranate or Queen's Sweet Pocket Melon-Fruit deliciously perfumed and may be carried in the pocket or laid among linens. Plkt, 10c.

Balsam Apple and Pear-Very curious, rapid and dense climbers, with ornamental foliage and golden yellow fruit, which open when ripe, showing the seed and blood-red interior. 1 oz., 35c.

\section{Cypress Vine}

Delicate fern-like foliage and beautiful star-shaped flowers. Mixed-scarlet and white. Pkt.

\section{Canary \\ Bird Creeper}

Somewhat resembles the climbing Nasturtiums and is a good climber. Pkt., 5c.

\section{Cobea Vine}

One of the finest of all climbers, bearing large, bell-shaped purple flowers in profusion. Pkt.,

\section{Gourds}

Thrifty annual climbers, 10 to 30 feet high, bearing "ornamental gourds."

\section{New Japanese Variegated Hop}

Leaves beautifully variegated with silvery white and dark green; very effective for screens, arbors, trellises, etc. Pkt., 10c.
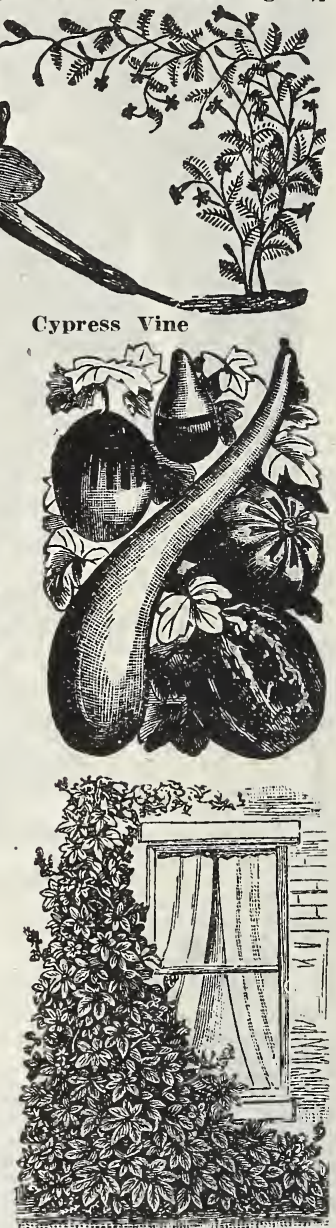

Japanese Hop

\section{Kudzu Vine or Japanese Flowering Bean}

This is the most rapid growing vine known (12 inches in one day). It has a tuberous root, which is perfectly hardy everywhere, and in spring sends up vigorous shoots, which will quickly shade the entire plaza front. It will grow 50 feet the first summer from seed sown in the open ground in-May. Its foliage is very luxuriant and its rose-colored fragrant flowers are produced in large clusters. For covering porches, arbors, fences, stumps, dead trees, etc., with a luxuriant curtain of foliage, and in the shortest

\section{Hyacinth Bean or Dolichos}

Annual climbers of rapid growth; bearing large clusters of purple and 
A R CHI A ' SEED STORE, SEDALIA, MISSOURI

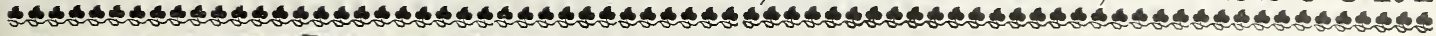
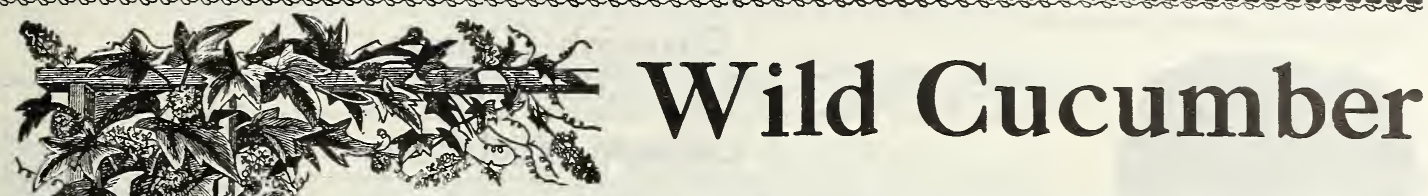

This is the quickest growing Climber in our list. It will grow thirty feet in one season. It is thickly dotted with pretty white fragrant flowers, followed by an abundance of ornamental prickly seed pods. Pkt., 5c; $1 / 2$ oz., 10c; oz., $15 \mathrm{c}$.

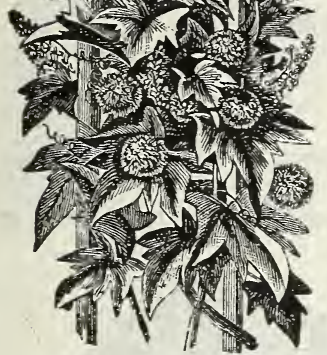

\section{Moon Flowers or Evening Glories}

A beautiful rapid climber, having large flowers from 4 to 6 inches in diameter, which open in the evening.

\section{Giant White-Packet, 10c.}

Giant Pink-Packet, 10c.

Heavenly Blue-Flowers 4 to 5 inches across; color, sky-blue. Pkt., Oc.

Setosa (Brazllian Morning Glory)-Packet, 10c

Ipomoea Coccinea (Star Ipomoea)-Star-shaped scarlet flowers. Pkt., 5c.

Ipomaea Bona Nox (Evening Glory)-Fragrant, violet flowers. Pkt., 5c.

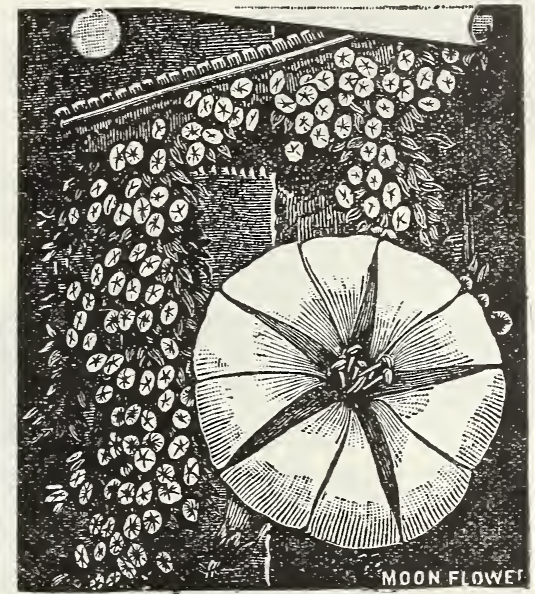

\section{Hyacinth Bean or Dolichos}

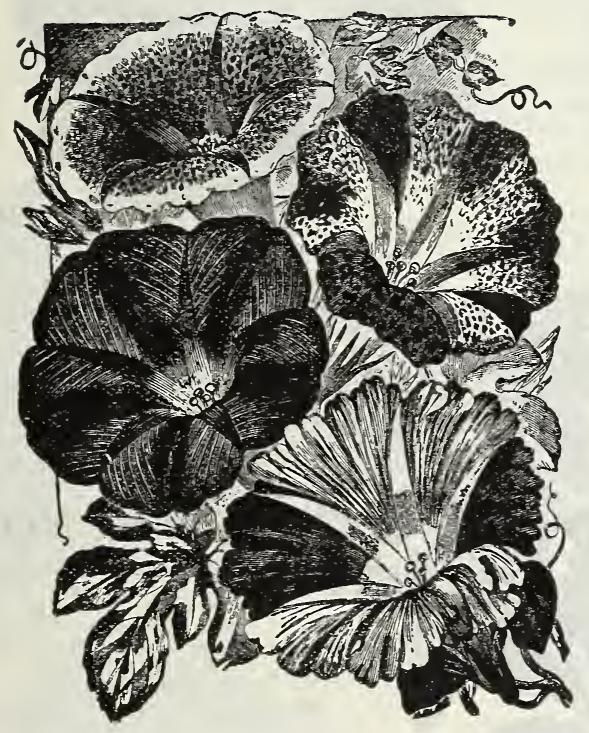

\section{Cannas, From Seed}

Large-Flowering French Hybrid Cannas-Seed saved by us from our superb collection. Early flowering and remarkable for large size and beauty of flower and foliage (see illustration). This elegant collection contains everything that is best in cannas. Large pkt., 10c; oz., 25c.

Madame Crozy Cannas-Flowers beautiful scarlet with gold border around each petal; foliage green. Pkt., 10c; oz., 25c.

Canna Roots-See Summer Flowering Bulbs, page 57. These grand New
Morning Glories from
Japan are remarkable
for their large size
and exquisite colors.
Grow quickly to a
height of 12 to $20 \mathrm{ft}$.
They are of innumer-
able shades of blue,
white, yellow, slate,
copper, brown, bronze,
almost black, and
often seven or eight
colors and tints in one
flower. Pkt., 5c; oz.,
35c.

Annual climbers of rapid growth; bearing large clusters of purple and white flowers, followed by bright purple pods.

\section{Imperial Japanese Morning Glories}

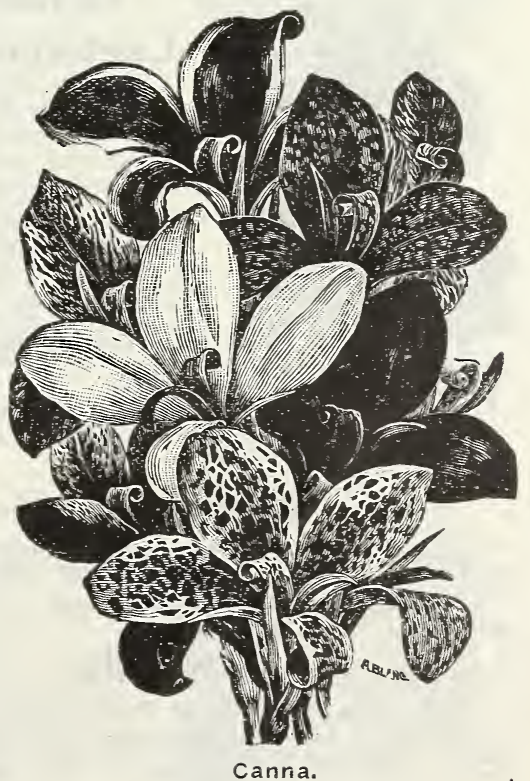




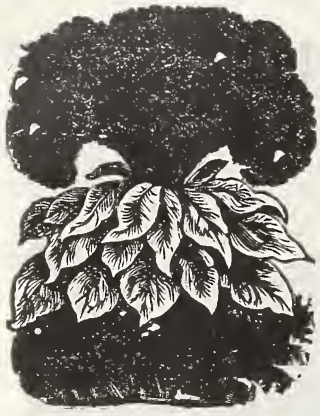

Coxcomb

\section{Coxcomb (Celosia)}

Glasgow Prize; also called Pres. Thiers-Large and very showy dark crimson combs. of the most popular varieties. Nine inches. Pkt., 5c.

\section{Chinese Woolflower}

A distinct form of the plumed Celosia. The plants average two feet in height, branching freely, each shoot bearing beautiful, ball-shaped flower-heads of purplish-crimson the flower-heads retaining their full beauty and color until severe frost destroys them A novelty of great merit. Pkt., 15c; 2 pkts., 25c.

\section{Chrysanthemum (Field Daisies)}

Annual plants, grow 12 inches high, have fine, delicate foliage and produces beautiful daisy-like flowers of various bright, rich

Double and Single Mixed-Pkt., 5c; 1/4 oz., 10c; oz., 30c.

\section{Cineraria}

A favorite free blooming greenhouse plant of wondrous beauty, with flowers of great richness and diversity of color.

Cineraria Hybrids, good mixture, pkt, 100 .

Giant Flowering Hybrids-Extra choice English, German and French prize varietie mixed. Pkt., 20c.

\section{Daisies}

Daisy, Double Perennial Mixed (Bellis)-Will bloom the first seaon ink, white and red. Pkt., 10c.

Shasta-Originated by Burbank; extensively known everywhere. Flowers are double in size of our ordinary field daisy. Pkt., 10c.

Field Daisies-See Chrysanthemums.

\section{Datura (Trumpet Flower)}

Finest Double Mixed-A very choice assortment of all the best colors and varieties of this effective annual. Pkt., 5c.

\section{Digitalis}

"Foxglove"-Ornamental, hardy border plants, easy culture, having long spikes of showy flowers, 3 to 5 feet. Mixed colors, 5c.

\section{Dahlias, From Seed}

Dahlias are easily grown from seed and bloom the first season; the earlier they are started the better, which can be done nicely in a box in a sunny window or the greenhouse.

Large Flowering Choicest Double Mixed-This elegant assortment of seed is saved from the most select and perfectly double varieties. (See illustration). Pkt., 10c; $1 / \mathrm{s}$ oz., 30c; $1 / 1 / 2$ oz., 50c.

Striped and Spotted Varieties-A very beautiful class, with finely cut foliage and large single flowers of perfect form and many brilliant colors. Pkt., 10c; 1/8 oz., 20̃c.

Cactus Varieties Choicest Mixed-Most popular at the present time; distinct and elegant; petals pointed; blooms perfectly double. Plit., $10 \mathrm{c} ; 1 / 8$ oz., 35c.

Giant Perfection Single Mixed-Splendid assortment of single flowering varieties. (See illustration). Pkt., 5c; 1/4 oz., 25c.

Double and Single. Finest Mixed-Splendid mixture of above varieties. Pkt., $10 \mathrm{c} ; 2$ pkts, $15 \mathrm{c}$.

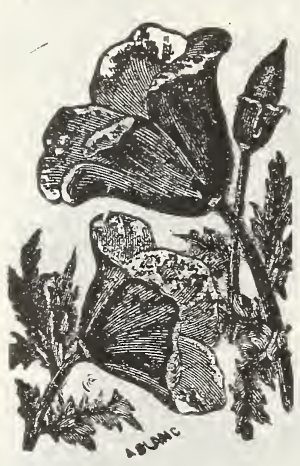

"The Golden West"

\section{Eschscholtzia (California Poppies)}

"The Golden West"-Magnificent flowers of gigantic size. Color intense shining yellow and orange. The state flower of California. Pkt., 5c; $1 / 4$ oz., 15c.

Burbank's New Crimson Flowering-A beautiful new strain of giant flowering Eschscholtzia, producing in great abundance clear rosy, crimson flowers. Bushy plants rosy, crimson flowers. Bushy plants about one foot high. New and very dainty., 30c.

Finest Single Mixed-Many choice varieties. Pkt., 5c; oz., 25c.

\section{Mourning Bride}

Scadiosa-One of our handsome summer border plants, producing a great profusion of very double flowers for table bouquets, etc. : hardy annuals.

Double Dwarf Varieties-Mixed, pkt., 5c. Large Floworing Tall Mixed, pkt., 5c.

\section{Nigella}

Love in a Mist, or Devil in the Bush.

A compact, free-flowering plant, with finely cut foliage, curious looking flowers and seed pods; of easy culture; hardy annuals; blue and mixed; 1 foot. Pkt., 5c; oz., 25c.

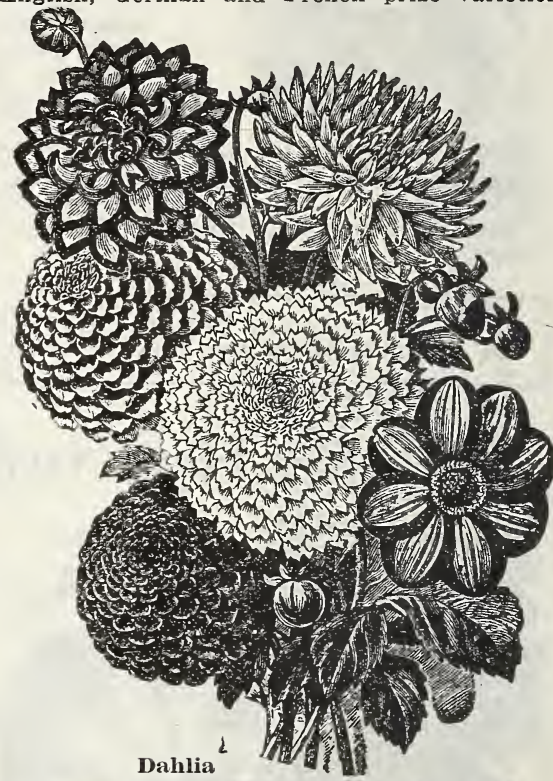

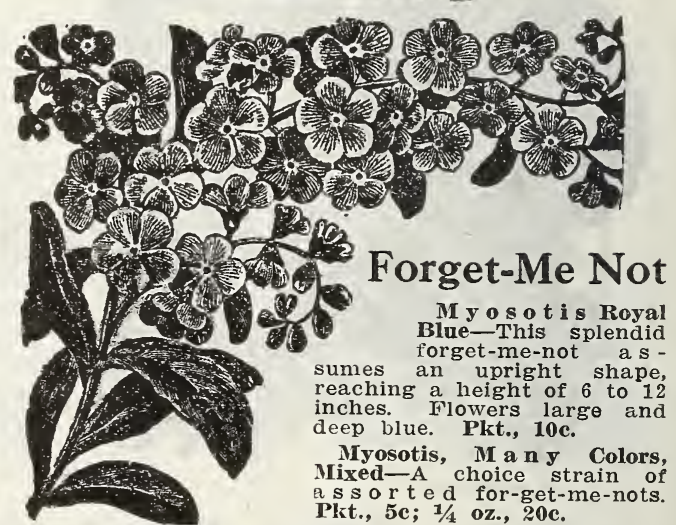

\section{Musk Plant}

Mimulus Moschatus-Fine for hanging baskets, etc.; small yellow flowers; the foliage has a strong odor of musk. Pkt., 5c. Nicotiana

\section{Sweet Scented Tobacco Plant.}

Attains a height of about 2 feet and produces an abundance of flowers of delicate fragrance. If talken up in the fall, cut back and potted, they will bloom all winter.

Nicotiana Sanderae-A new Brazilian flowering tobacco of great beauty and fragrance, equaling Salvia and more beautiful in colors. Do not fail to try it. Pkt., mixed colors, 10c. 
A R C I A S , SEED STORE, SEDALIA, MISSOURI

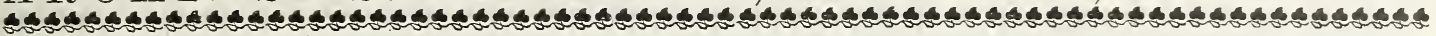

\section{Archias' Everlasting or Straw Flowers}

These are not only ornamental during the summer, but are very pretty for winter decoration, lasting for years

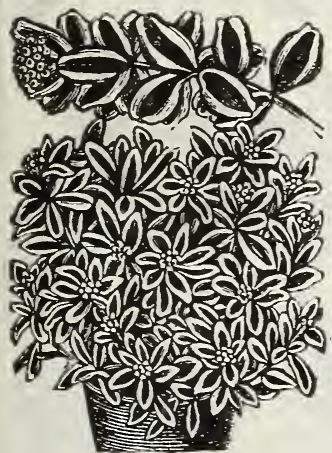

Euphorbia

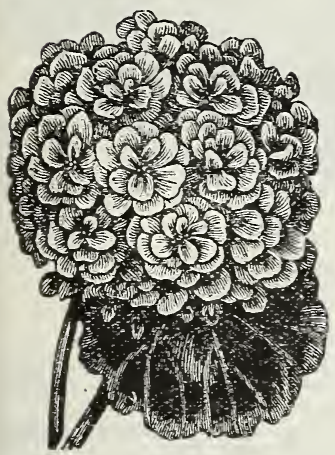

Geraniam

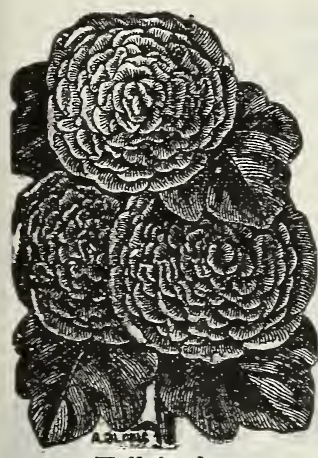

Hollyhocks

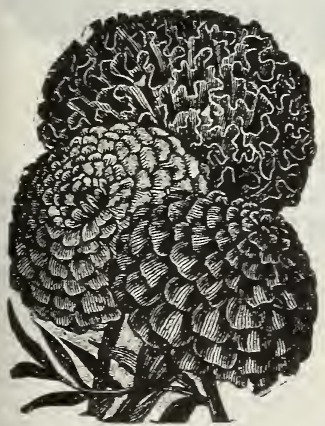

Marigold
ACROCLINEUM-Double anid single. Pkt., 5e.

Globe Amaranth, or Bachelor's Buttons, Mlixed-Two feet high, producing small, globe-shaped, double flowers in bright

colors. Pkt., 5c; oz., 20c. be dyed any color. Pkt., 5c.

\section{Euphorbia}

Annual plants, with handsome foliage; 2 to 4 feet. Effective for bedding.

Variegat - Snow on the Mountain. A showy border plant, with tive. Pkt 50.

Heterophylla-Fire on the Mountain. Ornamental leaves, which take on a deep fiery appearance. Pkt., 10c.

\section{Gaillardia}

The Blanket Flower Exceedingly beautiful perennial, making very showy plants, one foot high. Grown in mass they are especially effective. Finest varieties, mixed, 5c.

\section{Geraniums}

These grow rapidly from seed and produce blooming flants the first sum-

Zonale Varieties-Our mixture includes the very finest varieties and new sorts. Pkt., 10c.

\section{Heliotrope}

A well known genus of profuse flowering and deliciously fragran plants; splendid for bedding or ribboning, and for basket or pot culture. Half hardy perennials, 18 inches high. Fine mixed, choice varieties, per pkt. 10c.

\section{Hibiscus}

Crimson Eye-These immense flowers of pure white, with a large crimson eye, often 7 inches in diameter and crant will often have as many as fifty of then. It blooms from seed the first year, sown in open ground. A perennial, and lasts year after year. Pkt. 10c.

\section{Hollyhocks}

For majestic growth and massive beauty the Hollyhock stands unrivaled. of double flowering sorts, containing many fine colors. Pkt., of double flowering sorts, containing many fine colors. Pkt. Double Allegheny-Rich colors, fringed petals. Pkt., 10c; 1/4 oz., 35c.

\section{Ice Plant}

Handsome and curious plants for hanging baskets, rock work, vases and edgings. Leaves and stems succulent, appearing as though covered with crystals. Tender annual trailer; six inches high. Pkt., 5c; 1/4 oz., 15c.

\section{Job's Tears}

Hardy Annual Grass-An ornamental grass, with broad, corn-like leaves and hard shining seeds of peculiar appearance, giving the plant its name. Two feet. Pkt., 5c; oz., 15c.

\section{Larkspur}

Well-known annuals of great beauty and noted for richness of their colors.

Double Dwarf Rocket-Finest Mixed, pkt., 5c; 1/4 oz., 15c.

Double Tall Rocket-Mixed, plit., 5c; $1 / 4$ oz., 15c.

\section{Lobelia}

Crystal Palace Compacta-Best dark blue sort for edgings and carpet bedding. Pkt., 10c; $1 / 8$ oz., 30c.

Emperor William-A brilliant, compact growing, light blue; a very fine variety. Pkt., 10c; $1 / 8$ oz., 25c.

lixed Compacta sorts-A very fine mixture of all the best varieties for edging and bedding. Pkt., 5c; 1/4 oz., 25c.

\section{Mignonette}

(Reseda odorata)

Archias' Golden Nugret-Introduced by us in 1905. The fragrant flowers are borne in great profusion the entire season, standing the hot suns of summer. It is also an excellent pot plant for greenhouses and conservatories. Pkt. lent pot plant for greenhouses and

Golden Machet-Very dwarf, of vigorous growth, massive spikes of deliciously scented red flowers. Pkt., 5c; oz., 15c.

\section{Marigold}

A well known magnificent plant, with handsome flowers of rich, beautiful colors, and neat, compact, green țoliage, producing a splendid effect in almost any situation. Half-

Double Tall African; Double Dwarf French; Gold StripedEach, pkt., 5c.

\section{Marvel of Peru}

Four o'Clock-Old favorite. Pkt., 5c.

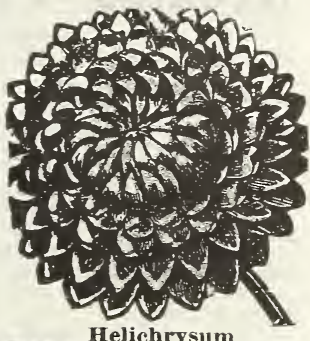

Helichrysum 


\section{Archias' Finest Tall Nasturtiums}

The Tall Nasturtium is one of our prettiest and bēst trailers. It blooms more freely than dwarf varieties.

Prices of following named Tall Varieties-Pkt., 5c; oz., 20c; 2 oz., 35c; $1 / 4$ 1b., 50c.

Dark Crimson-Deep, rich and velvety crimson.

Dunnett's Orange-Bright orange, blotched red.

Tall French Chameleon-A tall growing sort; flowers have the same habit of continuous change of colors as those of the Dwarf Chameleon. Jupiter-A giant-flowered sort; deep golden yellow; of the strongest growth; profuse bloomer.

Tall King Theodore-Deep crimson maroon; velvety, almost black; has dark foliage. One of the best sorts.

Tall Pearl-The nearest to white of any. Makes a fine contrast with other sorts.

One package each of the above six gorgeous Tall Nasturtiums for only 20c.

Tall Nasturtiums, Finest Mixed-Oz., 15c; 2 oz., 25c; 4 oz., 40c; 1 1b., \$1.00.

Madame Gunther Hybrid Clinbing Nasturtiums-These are of French origin, and for rich colors are not surpassed by any class of climbing nasturtiums. The foliage is mostly dark, and forms a striking contrast with the rich and velvety flowers. Plat. 5c;

Lobb's Finest Mixed Tall Nasturtiums-This mixture is composed of the finest and most distinct varieties in this grand free-flowering type. Planted in masses it will produce most gorgeous and showy effects. Plkt., 5c; oz., 20c; 2 ozs., 35c; $1 / 4$ 1b., 50c; 1 1b., \$1.25.

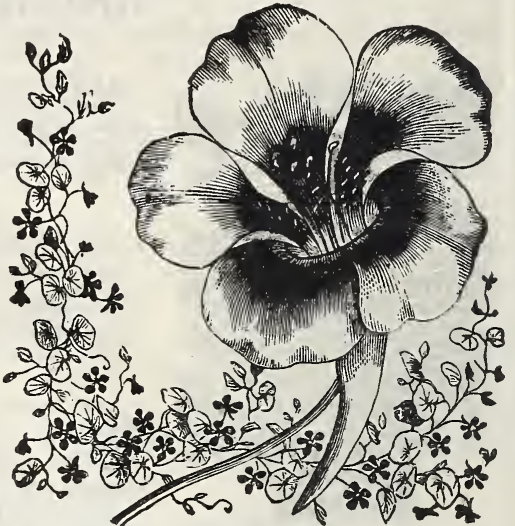

ARCHIAS' SPECIAL MIXTURE OF NAMED TALL NASTURTIUMS.

Pkt., 5c; oz., 20c; 2 ozs., 35c; $1 / 41 b$. 50c; 1 1 1b., \$1.25.

\section{ARCHIAS' BRILLIANT DWARF NASTURTIUMS}

Queen of Tom Thumb-The first of a new race of nasturtiums with silver variegated foliage, making a strikingly handsome bedding and pot plant even before blooming. The flowers are rich, bright crimson and give an effective contrast with the handsome foliage. Very fine. Pkt., 10c.

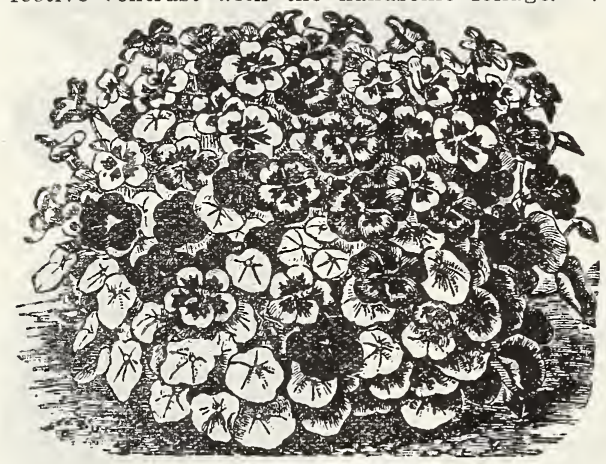

CHAMELEON.

Price of following named Dwarf Varieties: Pkt., 5c; oz., 20c; 2 ozs., 35c; $1 / 4$ lb., 50c.

Aurora--Yellow petals, blotched veined carmine.

Lady Bird-Yellow, barred with ruby crimson.

Beauty-Scarlet splashed canary.

Golden king-Golden yellow; very fine.

Empress of India-Dark leaves, crimson flowers.

Dwarf Chameleon-This new sort produces on the same plan many colored flowers, curiously stained or flushed, on clear ground, while others are broad-edged with light or dark margins.

One package each of the above seven superb Dwarf Nasturtiums, including Queen of Tom Thumb, for only 25c.

A bed of divarf nasturtiums is very brilliant and attractive.

\section{Archias' Special Mixiure of Named} Dwarf Varieties.

Pkt., 5c; oz., 20c; 2 ozs., 35c; 4 ozs., 50c; lb., \$1.25.

Dwarf Mixed-Oz., 15c; 2 ozs., 25c; 4 ozs., 45c; lb., $\$ 1.00$.

\section{Archias' Large Flowering Phlox}

Large Flowering or Grandiflora Varieties-These are a great improvement on the older sorts, producing flowers almost double the size.

Large Flowering Dwarf-Fine for pots, bedding and borders. Brilliant in color and profuse in bloom. Height, 6 inches. Mixed colors, pkt., 10c; $1 / 8$ oz., 25c.

Star and Fringed-Extremely beautiful and of the most varied colors. The st.ir-shaped varieties are distinctly bordered with white. Plkt., 5c; $1 / 8$ oz., 20c.

Mixed-A splendid mixture of all the large flowering varieties. Pkt., $10 \mathrm{c} ; 1 / 4$ oz., 25c; oz., 65c.

\section{Archias' Hardy Perennial Phlox}

Perennial Phlox is one of the show features of our nurseries. Our seed is largely our own saving from a magnificent collection, embracing all the new and standard sorts of every color.

Finest Mixed-Every color, unsurpassed in quality. Pkt., 10c; 3 pkts., Pinks-See Carnations.

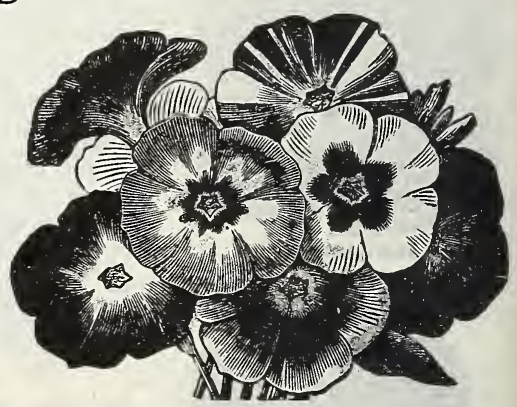

\section{Best Distances For Planting Fruit Trees and Plants}

Standard apples, 30 feet apart each way.

Standard pears and strong growing cherries, 50 feet a part each way.

Duke and Morello cherries, 18 feet apart each way. Standard plums, apricots, peaches, nectarines, 16 to 18 feet apart each way.

Dwarf pears, 10 to 12 feet apart each way.

Dwarf apples, 10 to 12 feet apart each way.

Quinces, 10 to 12 feet a part each way.

Grapes, rows 10 to 12 feet apart: 6 to 10 feet in row.

Currants and gooseberries, 4 to 6 feet.

Raspberries and blackberries, 4 to 6 feet.

Strawberries for field culture, 1 by $31 \frac{1}{2}$ feet.

Strawberries, for hill culture, 2 feet a part each way.
Table Showing Number of Plants of Trees to the Acre of Given Distance

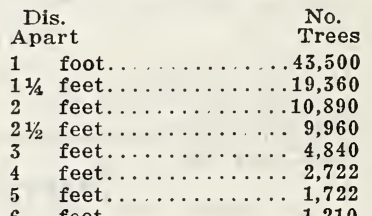

6 feet.

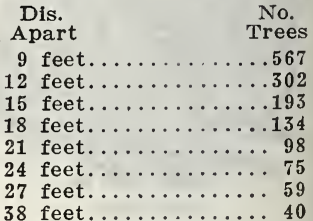




\section{ARCHIAS' GIANT PANSIES From the BestPausy'Seed Growers-No FinerGrown}

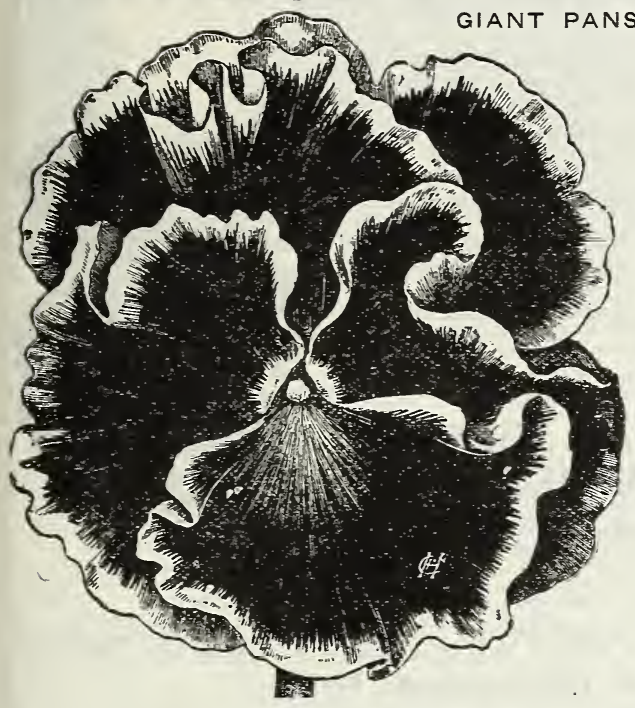

These Pansies are noted for freedom of bloom, brilliancy of coloring, perfection of form, and splendid velvety substance. They prefer a moist, shady situation.

\section{BUGNOT'S NEW GIANT BLOTCHED}

celebrated French strain, noted for their extra large size and remarkably rich and varied colors. They comprise many shades and tints of red, brown and bronze, seldom found in other Pansies. Unquestionably one of the finest strains of Pansies grown. Pkt., 15c; 2 pkts., 25c; 1/8 oz., 75c; $1 / 4$ oz.. $\$ 1.25$.

\section{PRESIDENT MCKINLEY}

Almost black, with yellow margin; $21 / 2$ to 3 inches in diameter. The blotches are really dark reddish brown, exceedingly rich. A magnificent Pansy. Pkt., 5c; 2 pkts., 25c; 1/8 oz., $75 c ; 1 / 4$ oz., $\$ 1.25$.

\section{GIANT MADAME PERRET}

A beautiful race of giant Pansies, characterized by delicious shades of wine-red flowers, 3 to $31 / 2$ inches across. Every blossom exhibits the soft wine-red color, in varying degree, either faint or intense. Pkt., 15c; 2 pkts., $25 \mathrm{c}$; 1/8 oz., $75 \mathrm{c}$ $1 / 4$ oz., $\$ 1.25$.

\section{ARCHIAS' GIANT FLORIST'S MIXTURE}

Carefully prepared mixture of the richest, handsomest and largest Pansies known. Most profitable Pansies for Florists. Pkt., 10c; 1/8 oz., 75c; 1/4 0z., $\$ 1.25$; 0z., $\$ 5.00$.

\section{MASTERPIECE}

(NEW GIANT CURLED).

This grand Pansy is remarkable for having its petals waved or folded, as shown in the illustration. The flowers are large and round. Every petal has a dark blotch and there is usually a light edge or border. Highly fashioned everywhere. Pkt., 15c; 2 pkts., 25c; $1-16$ oz., $75 \mathrm{c}$; $1 / 4$ oz., $\$ 2.00$.

\section{ARCHIAS' SPECIAL GIANT PANSY COLLECTION}

One package each of Masterpiece, Bugnot's, President McKinley, Madame Perret and 'Archias' Florist's Mixture, 5 packets in all. Only 45 cents, or two collections for $80 c$, postpaid.

\section{STANDARD BEDDING PANSIES}

THE.CREAM OF THE STANDARD SORTS

Two pkts. Pansies, your choice, 15c; or 4 pkts. for 25c. You can have a bed of finest Pansies for a few cents.

Giant Trimmardeau-Dark blue. Pkt., 10c; 1/8 oz., 30.

Archias' Giant Yellow-New, black eye. Pkt., 10c; 1/8 oz., 30c.

Archias' Giant Butterfly-A mixture of beautiful, showy flowers. Pkt., 10c; 1/s oz., 30 c.

Archias' Peacock-Of large size, the side petals are as beautiful as a peacock and very striking. Pkt., 10c; $1 / 8$ oz., 75c.

Archias' Giant Striped-Elegant Show Pansies. Pkt., 10c; 1/8 oz., 75c.

Emperor William-Ultramarine blue, with dark center. Pkt., 10c; 1/8 oz., 35c.

King of the Blacks-Pkt., 10c; $1 / 8$ oz., 25c.

Archias Fire King-The three lower petals each have a deep brown red blotch, with A Pkt., $10 \mathrm{c} ; 1 / 4$ oz., 35c.

Archias' Snow Queen-Satiny wh:te. Pkt., 10c; 1/8 oz., 30c.

German-Finest mixed, large, fine colors. Pkt., $10 \mathrm{c} ; 1 / 8$ oz., $30 \mathrm{c} ; 1 / 4 \mathrm{oz}$., $50 \mathrm{c}$

SPECIAL OFFER-One package each of the ten elegant Standard Bedding Pansies described above for 50 cents. Nothing could equal in gorgeousness the display these will make in your garden.

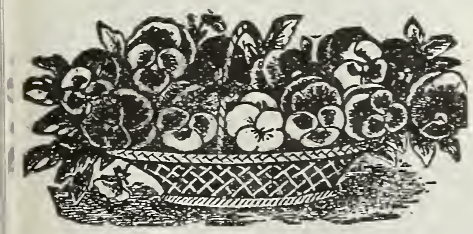

\section{Sweet-Scented Tufted Pansies}

\section{OLD-FASHIONED HEARTS EASE}

A distinct class of pansies that are much hardier than the common varieties. They are supposed to be a cross between the Sweet Violet and common Pansy. They grow in tufts and clumps, and bloom freely throughout the entire summer and fall. The colors range in shades of white, blue, yellow, violet, purple, etc. They are quite popular in England,- where they have been grown for years. Pkt., 10c; 3 pkts., $25 \mathrm{c}$.

PANSY PLANTS-We make a specialty of growing Pansy plants. These are grown from the best Mixtures of German, French and English varieties. We pack carefully and guarantee safe arrival. Postpaid, 50c per dozen; by express, $40 \mathrm{c}$ per dozen, or 3 dozen for $\$ 1.00$ for plants in bloom. 


\section{Archias' Gorgeous Petunias}

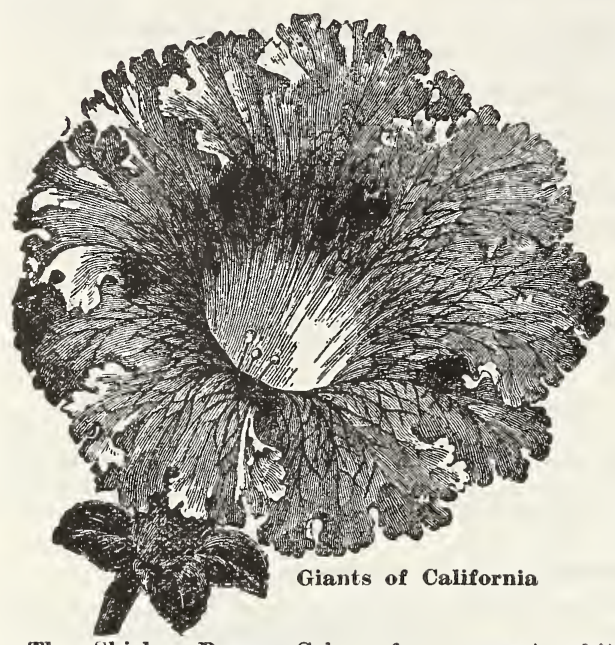

The Mikado-Of purest white and brilliant crimson scarlet; large double flowers of quaint artistic beauty, with petals deeply cut and fringed. Pkt., 10c.
The Shirley Poppy-Colors from purest white, rose, pink, carmine and crimson. Very interesting. Pkt., 5c.

Large Single Flowering Fringed-Superb mixture. Fine large, fringed flow-

Giants of California-Single, mixed. Flowers very large and of many beautiful colors. Pkt., 15c; 2 pkts., 25c.

Blotched and Striped Single-Beautiful large flowered, striped and blotched petunias of the most symmetrical shape pkts., 15c.

Finest Mixed Single-A splendid mixture of single varieties, beautifully striped, blotched and mottled. For borders and massing. Pkt., 5c; $1 / 4$ oz., 25c.

\section{ARCHIAS' SUPERB POPPIES}

Double Carnation Flowered-Of large size and a variety of colors. Pkt., 5e;
$1 / 2$ oz., 10c.

Archias' Peony Flowered-Double mixed. Pkt., 5c.

Tulip-Large, bright scarlet flowers, which are so dazzling in appearance as to remind one of a bed of scarlet tulips. Pkt., 5c.

\section{PORTULACA, or Rose Moss}

Excellent for edging beds, rockeries, etc. Succeeds in a sunny situation and produces flowers of almost every color in the greatest profusion. Large Flowering Single, many brilliant colors. Pkt., 10c; 1/4 oz., $15 \mathrm{c}$

Double Varieties, Mixed-A choice mixture of double varieties. Pkt., $10 \mathrm{c} ; 2$ pkts., $15 \mathrm{c}$.

\section{Smilax}

A valuable climber, elther for the house or conservatory. Per pkt., 10c; oz., 30c.

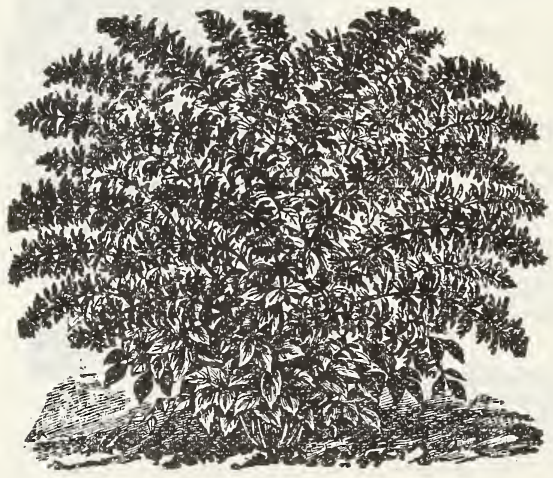

Bonfire
SALVIA, OR FLOWERING SAGE Splendens (Scarlet Sage) -Intensely rich, scarlet flowers that continue to bloom in profusion

frost. Per pkt., 10c. Bonfire-Flowers are of
brilliant. dazzling scarlet, brilliant. dazzling scarlet, sion and until late in fall. Pkt., 10c. largest and best. Pkt., 10c.

\section{Stocks}

\section{(Gilliflower)}

Finest Mixed-This is our very best mixture of large flowering stocks. The perfectly double flowers embrace every color and shade of these splendid annuals. Pkt., 10c.

\section{Sweet William}

As now improved. this popular flower makes a matchless border plant. A splendid strain of all bright colors of varieties.

Fine Mixed Single Varieties. Plkt., 5c.

Fine Mired Double Varieties. Pkt, 5c.

Iammoth-Mixed, Single Varieties. Pixt, 10c.

Mammoth-Mixed, Double Varieties. Pkt., 10c.

\section{Sunflower}

Cut and Come Again-Small yellow flowers with black center. Blossoms all summer. Pkt., $5 \mathrm{c}$.

California-Double Orange. Pkt., 5c.

Giant Russian-Flowers 20 inches across. Pkt., 5c.

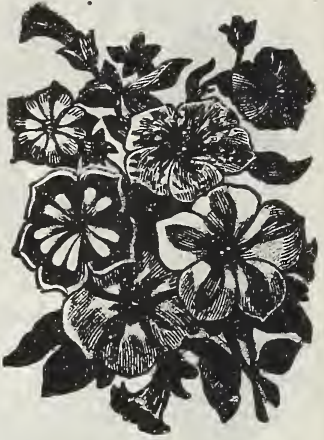


A R CHIA ', SEED STORE, SEDALIA, MISSOURI

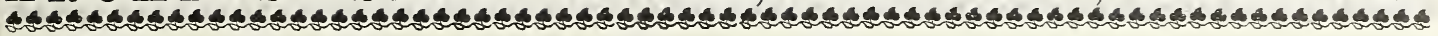

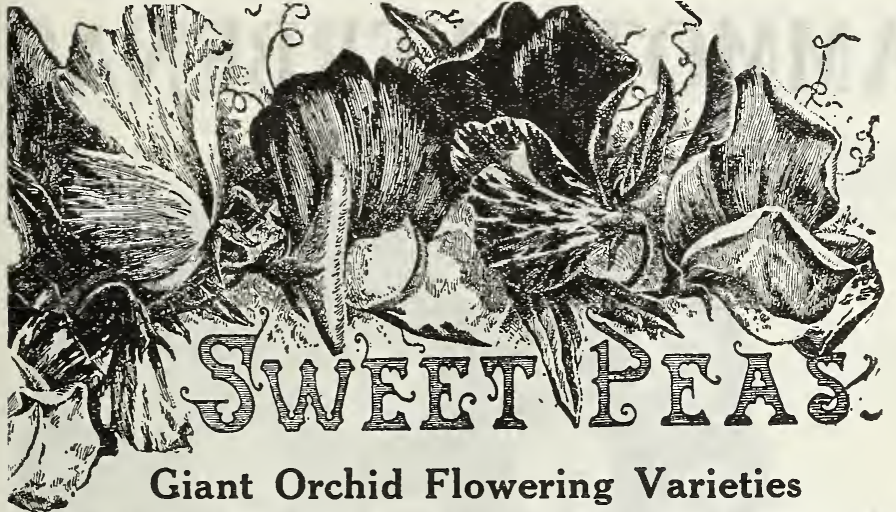

Archias White King-Produces gigantic flowers of an absolutely pure white Compared with white Spencer the entire vine seems to be twice as vigorous; the flower is of a purer white, of better substance and more finely placed on the thick, long stem. The standard is of finest form, decidedly frilled and waved, and terminates beautifully at the throat. Wings large, waved and graceful cover the keel.

Aurora Spencer-The large, beautiful flowers are produced profusely in threes and fours. The ground color is a cream-white, and this is exquisitely flaked and mottled with rich orange-salmon. It bunches beau-

tifully. Pkt., 10c; oz., 25c. Fy far the largest and best Lavender Spencer yet introduced. Originated by Alex. Dickson \& Sons, the noted rose growers of Belfast, Ireland. The flowers are truly magnificent and of immense ide, borne on long, stiff stems. True both as

George Herbert-We have a splendid re-selected strain of this most magnificent spencer. The gigantic bright rosy-carmine flowers of the largest size are generally borne four on a stem. Pkt., 10c; oz., 20c.

Gladys Unwin-Of the new orchid-flowering type, similar to Countess Spencer, but several shades lighter in its lovely pink color. Plkt., 10c;

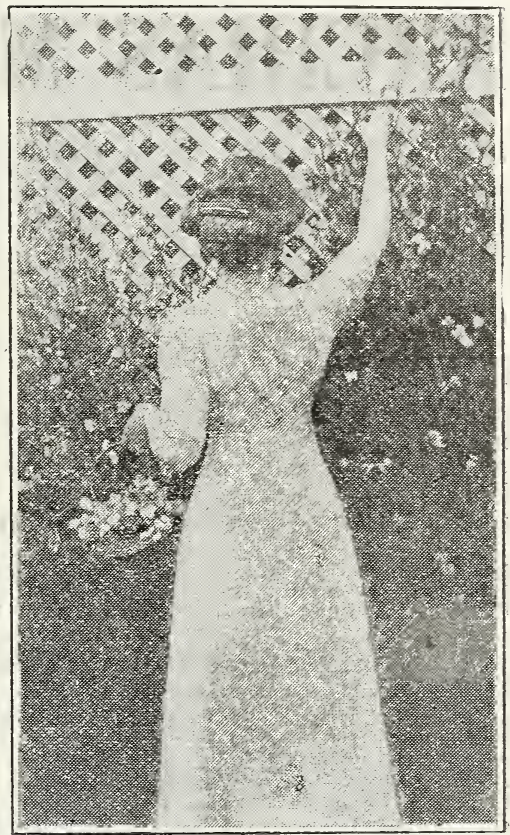

Countess Spencer z., 15c; 2 ozs., $25 \mathrm{c}$

Helen Lewis-A grand orchid-flowering seedling, orangerose wings and the standard intense rich crimson orange. Pkt., 10c; oz., 20c; 2 ozs., 35c.

King Edward Spencer-The unusually large wings make the flower appear truly gigantic in size, and the enormous flowers are frilled, waved and crinkled to a pronounced degree. The standard and wings are a deep, rich, rosy carmine scarlet, reverse of wings deep rosy carmine. Pkt., 10c; oz., 20c; 2 ozs., 35c.

Mrs. A. Ireland-The large standard is circular and nicely waved; of a very bright rose-pink, with a clear, creamy base. The wings, large and well expanded, are beautiful blush in color, but overlaid with rose on the exterior. Pkt., 10c; oz., 25c.

Princess Victoria (Spencer)-This beautiful, wavy, new Spencer was named for the Princess Victoria by royal
request. It might be described briefly as a lighter pink

Countess Spencer. Of most beautiful form and large Size. Received a certificate from the Royal Horticultural
Society and also the National Sweet Pea Society. Pkt., 10c; oz., 25c.

Senator Spencer-The color is a varying combination of deep claret and chocolate, striped and flaked on a ground of light heliotrope. There are usually four of the gigantic finely-formed flowers on each stem. The flowers are so much larger and handsomer than the Grandiflora Senator that it really should have had a distinct name. The vines are a perfect mass of bloom. Pkt., 10c; oz., 25c. Tennant Spencer-The best of the heliotrope shades. It is self-colored in most attractive rosy purple and comes entirely true. The flowers are of large size and borne gracefully on long, stiff stems. Pkt., 10c; oz., 25c. One packet each of the above ten wonderful Orchid
Flowered Sweet Peas for only $\% 5$ cents.

\section{New Spencer Hybirds-Mixed}

This Special Mixture, as improved, will give a rare treat to lovers of true "Spencer" Sweet Peas. It contains some most superb seedlings that have been introduced. The flowers are of extremely large size, most beautifully frilled and waved on the standard, with wellwaved wings. While the plants are vigorous in growth

and the gigantic flowers are borne most profusely on long, strong stems, yet, like all varieties of the true "Spencer" type, they are extremely shy seeders, and the seed can never be produced cheaply unless this superb new strain should be allowed to deteriorate. Pkt., 10c oz., 25c; \% ozs., 40c; $1 / 4 \mathrm{lb}$., $75 \mathrm{c}$; $1 \mathrm{~b}$., $\$ 2.50$, postpaid.

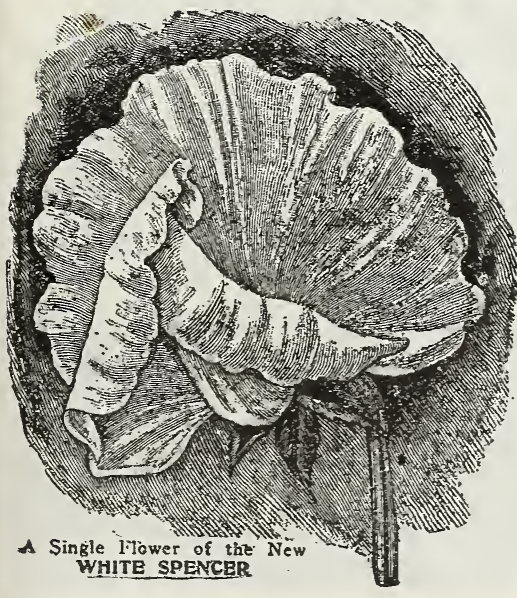

\section{Archias' Unsurpassed Sweet Peas in Mixture}

\section{Archias' Prize Mixture}

This is the finest mixture out, containing not only the most highly improved varieties from Eckford, but also many of the choicest varieties of recent introduction. Plkt., 5c; oz., 15c; 2 ozs., 25e; $1 / 1$, 1b., 40c;

\section{Eckford's Large Flowering Mixed}

This elegant mixture embraces the introduction, including the recent novelties of Mr. Eckford, the sweet pea specialist of England, who has accomplished more than any other individual in bringing the sweet pea to its present state of beauty, size and perfection. Pkt 5c; $^{\text {oz. }}$ c; 1/4 1b., 40c; 1b., \$1.25, postpaid. "By express, 1 1b., \$1.00; 3 los., \$2.75. ering Mixture, Blue, Red, Plnk and White Ribbon Mixture, all postpaid for only 15c; 2 collections for 25c. Do not fail to include these grand mixtures in your order.

\section{Hardy or Everlasting Sweet Peas}

Climbers, growing 6 to 8 feet. Flowers red, white and flesh colored. The roots penetrate the ground to a great depth and survive our wintere Mixed colors, pkt., 10c; 1/2 oz., 15c; oz., $25 \mathrm{c}$. 
GROW "S U R E SEE D ,', P L A N T S A N D T RE S

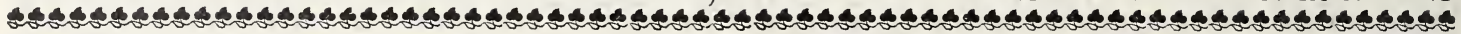

\section{ARCHIAS’ MAMMOTH VERBENAS}

A carefully selected and improved fine strain of verbenas. The trusses and individual flowers are of the largest size, of brilliant colors; free blooming and of vigorous habit. For best results seed should be sown early in the house or hot bed and transplanted in the beds in May.

Archias' New Mammoth-Pink. Pkt., 10c.

Archias' Mammoth White-Pkt., 10c.

Mammoth Scarlet Defiance-Pkt., 10c.

Mammoth Italian Striped-Pkt., 10c.

Auricula Eyed-Various colors. Flowers with large white eye, Pkt., 10c.

Archias' New Mammoth Mixed-Embracing all sorts, including the eyed and variegated verbenas. Pkt., $10 \mathrm{c} ; 1 / 4$ oz., 40c; oz., \$1.50.

Choice Mixed-Pkt., 5c.

\section{Vinca-Tender Perennial}

Periwinkle-A tender perennial plant blooming the first season. Adapted to window or open garden, making a fine show in the border; 18 inches high. Flowers $1 \frac{1}{2}$ inches across. Mixed, pkt., 10c.

\section{ARCHIAS' Sweet Violet \\ (Viola Odorata)}

Flowers of most delightful fragrance; popular with everyone. Sow seed in March or April in beds and transplant. Mixed colors, pkt., 10c.

Violet Plants-Best varieties. (See page 64)

Order a few extra flower seeds for your friends, nelghbors and your Sunday school class. You will not miss the cost, but will make many a glad heart.

\section{Archias' Gorgeous Zinnias}

Zebra-Large, perfectly double flowers, as evenly imbricated as a camelia. Flowers striped and mottled, presenting all colors and shades known in the zinnias. Giant Flowering-Mixed, pkt., 5c; 1/4 oz., 20c; oz.,

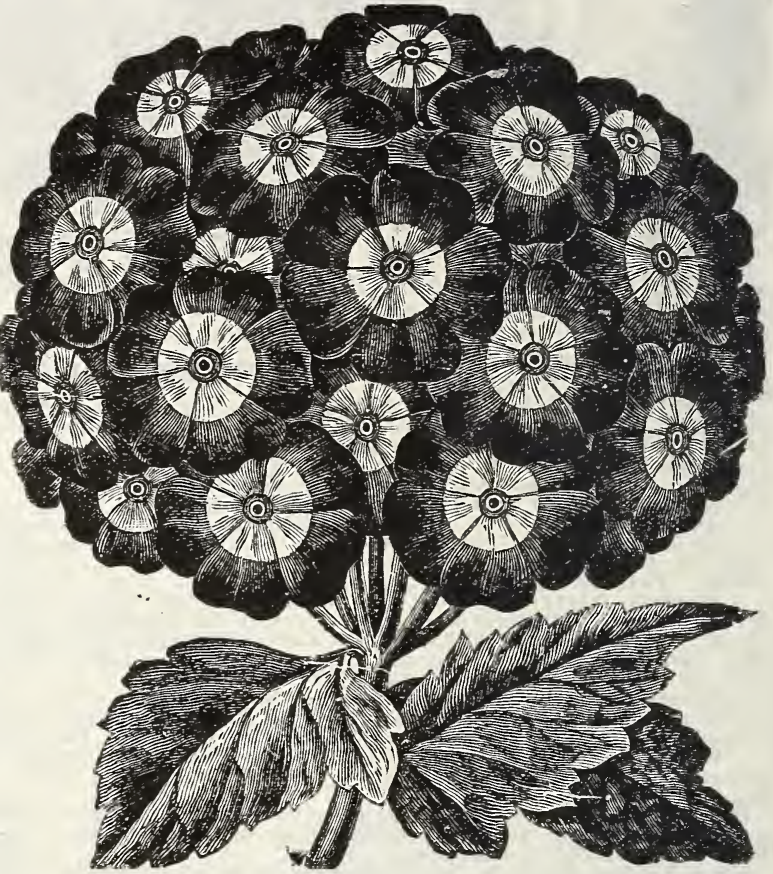
$60 \mathrm{c}$.

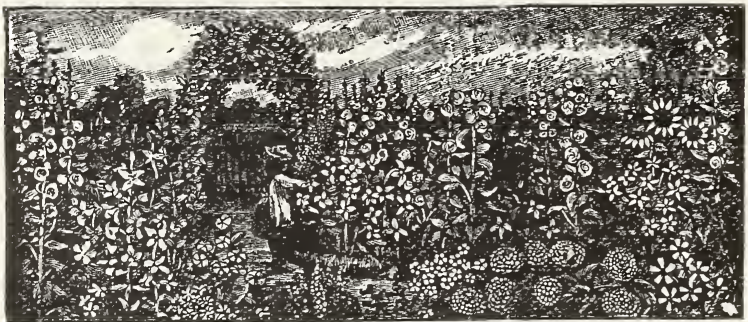

Double Dwarf Fireball-Deep, velvety crimson color; the richest in hue of all the zinnias Plant 18 to 24 inches high; a lavish bloomer. Pkt., 10c; 3 pkts., 25c. Improved Dwarf Mixture Zinnias-Pkt., 5c; 1/4 oz., 20c; oz., 60c.

\section{Wild Flower Garden Mixture}

These mixed flower seeds embrace a hundred varieties of easy-growing and pretty flowers, suitable for forming a wild flower garden. They are very useful for woodland walks and for sowing alongside fences and untidy bare spots of ground which are so frequently unsightly and which, if properly cared for and kept free from weeds, can be made to produce a continual display of bloom during the summer. Pkt., large, 10c; oz., 15c; $1 / 4$ 1b., 40c.

\section{How to Make a Hot Bed-By L. H. Archias}

Select a well-drained spot and make the pile of manure 15 to 18 inches deep; or a foot of soil may be dug out and filled in with manure well tramped down. Place the frame surface. Throw some manure or soil up against the outer boards to hold the heat. Put on the sash and keep tight for three or four days. Keep a thermometer in the bed, and when the temperature falls to 75 degrees seed may be sown with safety. The temperature in a hot bed should not be allowed to co above 70 degrees in the day nor below 50 at night With a hot bed the amateur can start almost any kind of vegetable or flower seed. By sowing such vegetables as egg plant, pepper, such flowers as heliotrope, scarlet sage, vinca, verbena, etc., along in March it is possible to have nice, tions are favorable, insuring early returns from the vegetables, and a long season for the flowers.

\section{Hot Bed Sash}

Single Glass - $3 \times 6$ feet, made of best grade cypress, without glass, each $\$ 2.00 ; 3$ for $\$ 5.50 ; 10$ for $\$ 1 \% .00$. Weight, 25 pounds each.

Same sash, with glass and painted with white lead and oil, each, $\$ 3.75 ; 3$ for $\$ 10.50 ; 10$ for $\$ 33.50$. Weight, 55 pounds each.

Hot Bed or Mushroom Bed Thermometer-Pointed brass bottom for plunging. Best grade. $\$ 1.50$, postpaid.

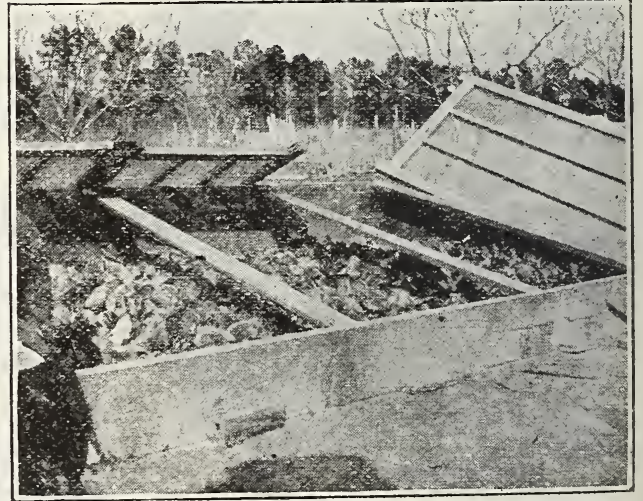


A R CH A S' SEED STORE, SEDALIA, MISSOURI

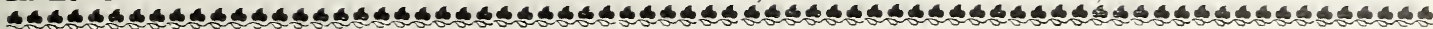

\section{ARCHIAS' GARDEN PLANTS AND BULBS}

We are owners of the largest system of Greenhouses and best Nursery in Central Missouri. Our plants are first-class, strong and healthy, and guaranteed to please. Send us your orders and you will not be disap. pointed.

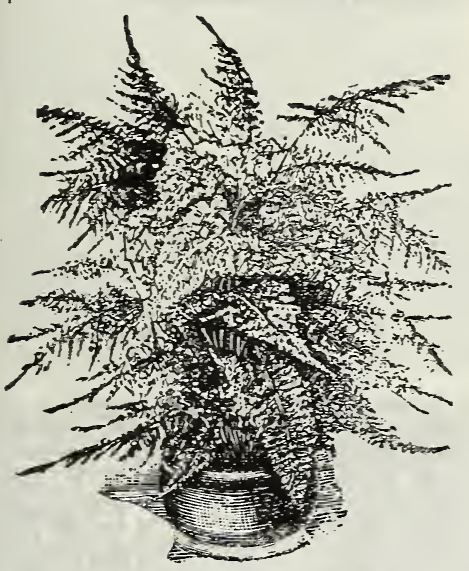

Asparagus Plumosus.

\section{Asparagus-Ornamental}

Each, 15c; 4 for 50c. Larger plants, each, 25c and 50c.

sprengeri-Rapid growing plants, of fine feathery foliage, exceedingly graceful and beautiful.

Asparagus Plumosus Nanus (Climbing Lace Fern)-Foliage equal to the most attractive fern.

\section{Achillea-The Pearl}

The great cemetery plant. Flowers pure white, perfectly double and produced in large sprays. For cemetery planting it is the most valuable of all flowers. Price, $15 \mathrm{c}$ each; 2 for $25 \mathrm{c} ; \$ 1.00$ per dozen, postpaid.

\section{Asters}

Archias' Giant Branching-A valuable strain for cutting and bor ders; separate colors or mixed. Doz., 50c; $100, \$ 3.50$. Samller plants, doz., $40 \mathrm{c} ; 100$ for $\$ 3.00$.

\section{Begonias}

\section{Best for House Culture}

Prices of any of the following: Each, 15c; 2 for 25c.

Gracilis Luminosa-A magnificent new specimen of the Semperfloens type, exceptionally sturdy and vigorous, and unquestionably one of the choicest bedding sorts in existence. Its flowers are large, perfect and plentiful, and never out of bloom. Color the brightest scarlet.

Rubra-Dark, glossy green leares. Freeflowering. For house or conservatory. Flowers a rich coral red, in large pendant panicles.

Alba Picta-Leaves green, spotted with white Flowers white, in clusters.

Beefsteak Begonia Feastii-A low-spreading begonia, with perfectly circular leaves, red beneath, and dark, glossy green above, and of heavy texture. The finest pot begonia we have for house culture Don't fall to try it Price, 15 cents each.

Corallina Lucerna-A superb new new variety of the coral begonia, producing gigantic trusses of bronzy red flowers and flower ing continuously from April to November. The foliage is dotted with silvery white. Price, 15 cents each.

\section{Begonias-Rex Varieties With Beautiful Foliage}

A collection of house plants without some Rex Begonias would certainly be incomplete. Every one admires their thick, leathery, brilliant leaves. Our assortment is superb. Each, $15 \mathrm{c} ; 6$ varieties for $75 \mathrm{c}$.

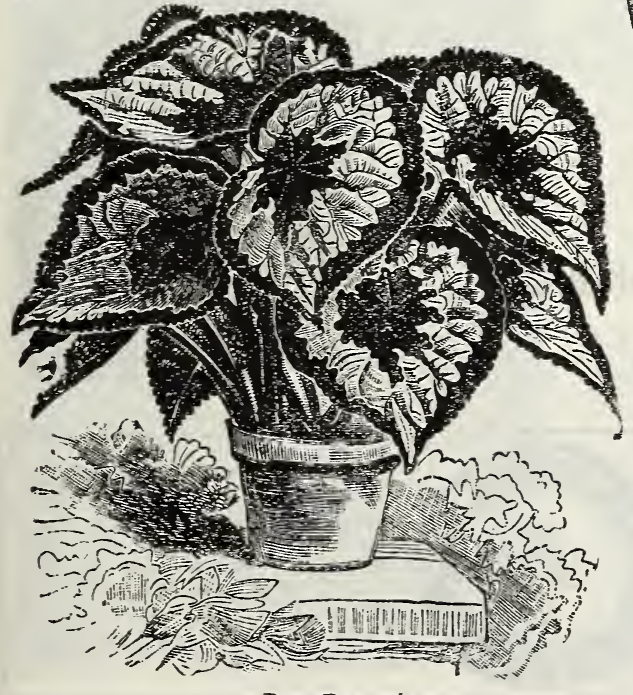

Rex Begonia

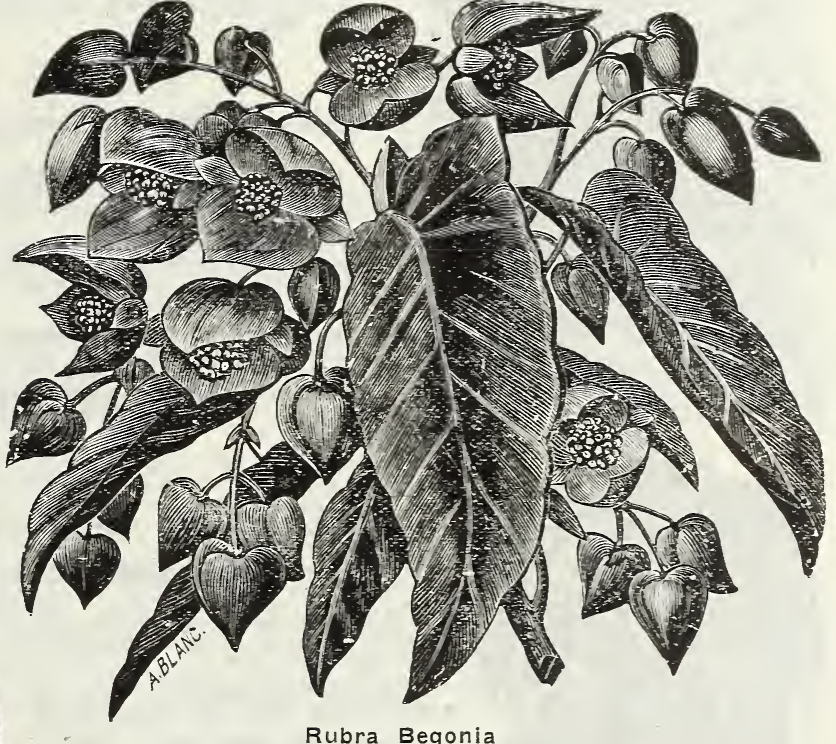

\section{"Bedding" Plants}

We grow immense quantities of this class of stock, and we are in a position to execute the largest orders in a prompt, satisfactory manner.

Per Doz. Per 100 Alternanthera-Red, yellow ............ $\$ 1.00 \quad 50 \quad 3.50$ $\begin{array}{rrr}50 & 3.50 \\ -50 & 3.00\end{array}$

Asters-Very fine varieties ............... $50 \quad 3.00$

Cannas-Roots to May 1st................... 1.00

Cannas-Plants after May 1st............... 1.50

Coleus-Bedding varieties $\ldots \ldots \ldots \ldots \ldots \ldots \ldots .6 .95$

Daisies-Hardy English ................. 75

Dusty Miller

Lobelits-Best dwarf blue............... 60

Pansies-Finest mixed ................. 40

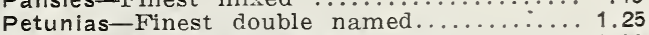

Petunias-_Single flowering $\ldots \ldots \ldots \ldots \ldots \ldots \ldots, 1.00$

Salvias-"Scarlet Sage" ................ 1.00

Verbenas-Red, white, blue, etc..............60 
GROW "SURE SEED S', PLA N T A N D T RE S

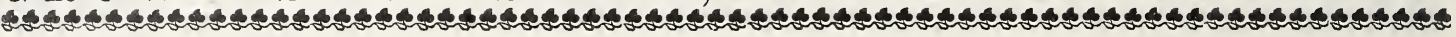

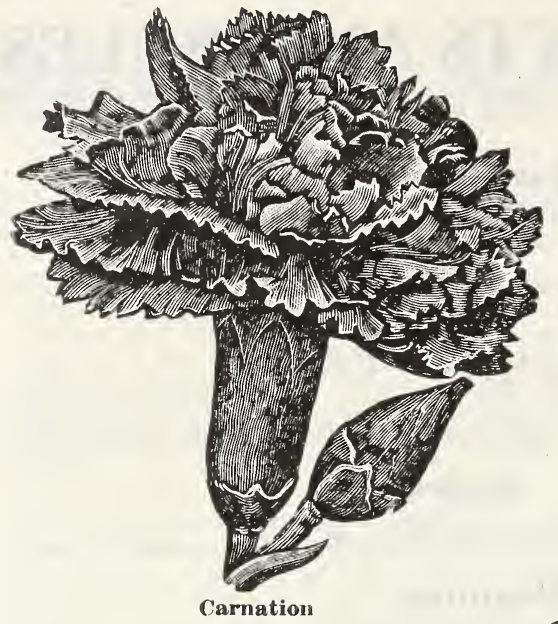

\section{ARCHIAS' CARNATIONS}

One strong plant of each of the 6 varieties, only $75 c$, postpaid.

\section{Six New Perpetual Bloomers}

Herald-The best red.

Sedalia-The best pink.

White Enchantress-The best white.

Cardinal-The best crimson.

Martha Washington-Best rose-pink. 15c each; 3 for 40c.

Helen Agnes-A handsome variegated sort; white, irregularly streaked with red. 15c; $\$ 1.50$ per dozen.

\section{HARDY GARDEN CARNATION OR SCOTCH PINKS}

These beautiful pinks are particularly valuable for beds, borders and edging in gardens, lawns, parks and cemeteries. They are entirely hardy, need no protection and bloom regularly every season without attention. They are fragrant, giving out a rich, spicy fragrance that is particularly attractive and quite unlike anything else in the flower world. A single plant will grow from twelve to eighteen inches in diameter. Can not be supplied in separate colors, but our stock contains all shades from pure white to light red. 12c each; 3 for 30c, postpaid.

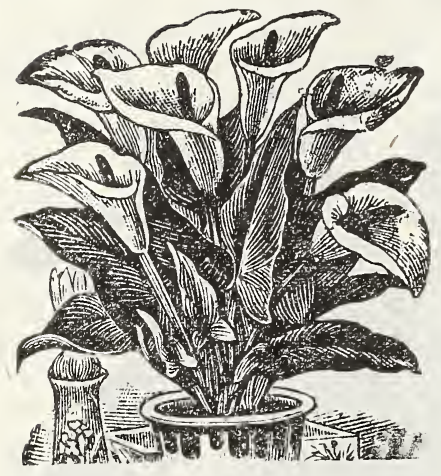

Calls

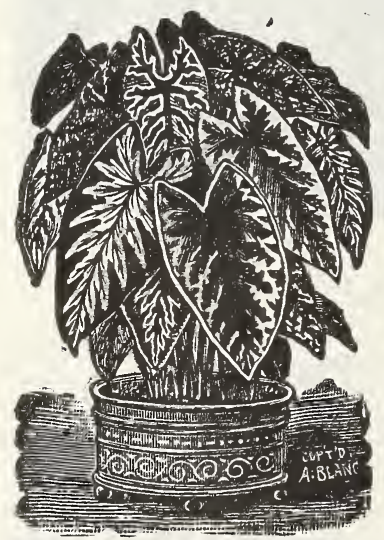

Fancy Leaved Caladium

A New Feature for the benefit of flower lovers. We have inaugurated the

"DOLLAR BOX" System in Sedalia Which is so popular in the Eastern Cities. ARCHIAS PAYS THE POSTAGE

Each box contains special value of at least two dozen seasonable flowers. Delivered anywhere in the city or by parcel post to your friends or family the city or by parcel post to your friends or family, RISK AND GUARANTEE SAFE ARRIVAL AND SATISACTION. Price, prepaid, just $\$ 1.00$. doz., 85c. for $25 \mathrm{c}$; doz, 6 to 20c each; 3 for 50c.

\section{Cinnamon Vine}

A fine, hardy climber; the tubers tiful, rapid grower, producing sweetscented flowers. Wach, $10 \mathrm{c} ; 3$ for $25 \mathrm{c}$

\section{Calla Lilies (Ethiopica)}

Large, beautiful, pure white flowLasy culture. Each, 20c; 2 for Spotted Leaf Calla-Dark green, eares beautifully spotted white, flow15c; 2 for 25c, postpaid.

The Godfrey Erer-blooming Calla -Flowers as large as the largpure white. Plant dwarf an

\section{Caladium Esculentum (Elephant's Ear)}

The most popular bulbous foliage plant. Good

Medium Bulbs-Eight to ten inches around. (35c; doz., $\$ 1.75$.

Mammoth Bulbs-Ten to twelve inches around.

\section{Fancy Leaved Caladium}

The fancy leaves are pot plants for the home but do quite well out of doors if in very rich soil and partial shade. (See illustrations). Not hardy.
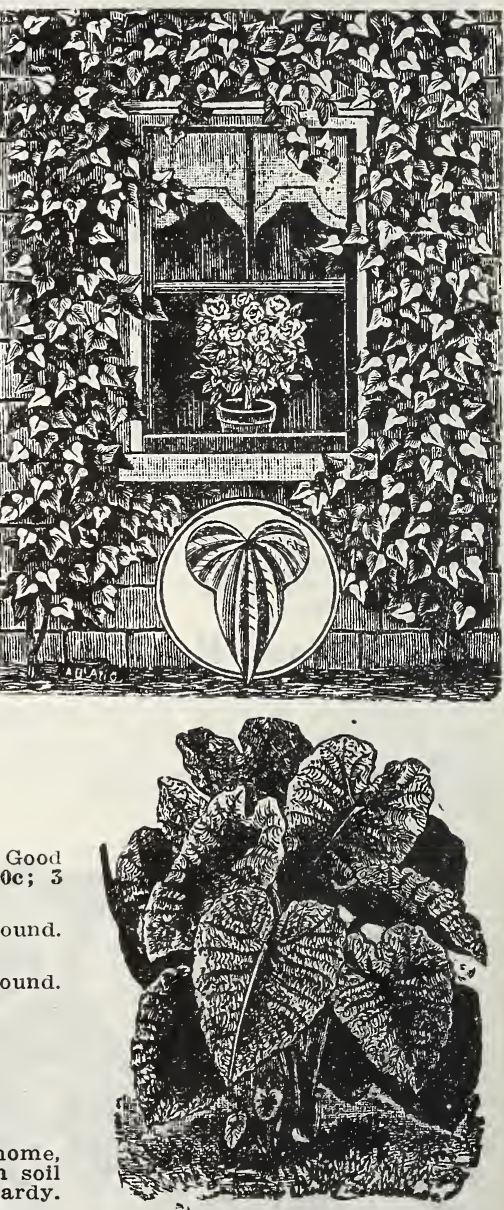

Caladium

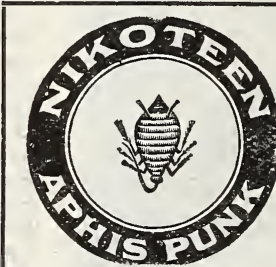

\section{Nikoteen for Spraying}

Purest and most economical Death to Aphis or Green Fly, Thrip and many other forms of Flowers, Fruit and Vegetable Lice.

1 lb., $\$ 1.50 ; 1 / 21 b ., 85 c ; 13 / 4$ oz., 40c. 


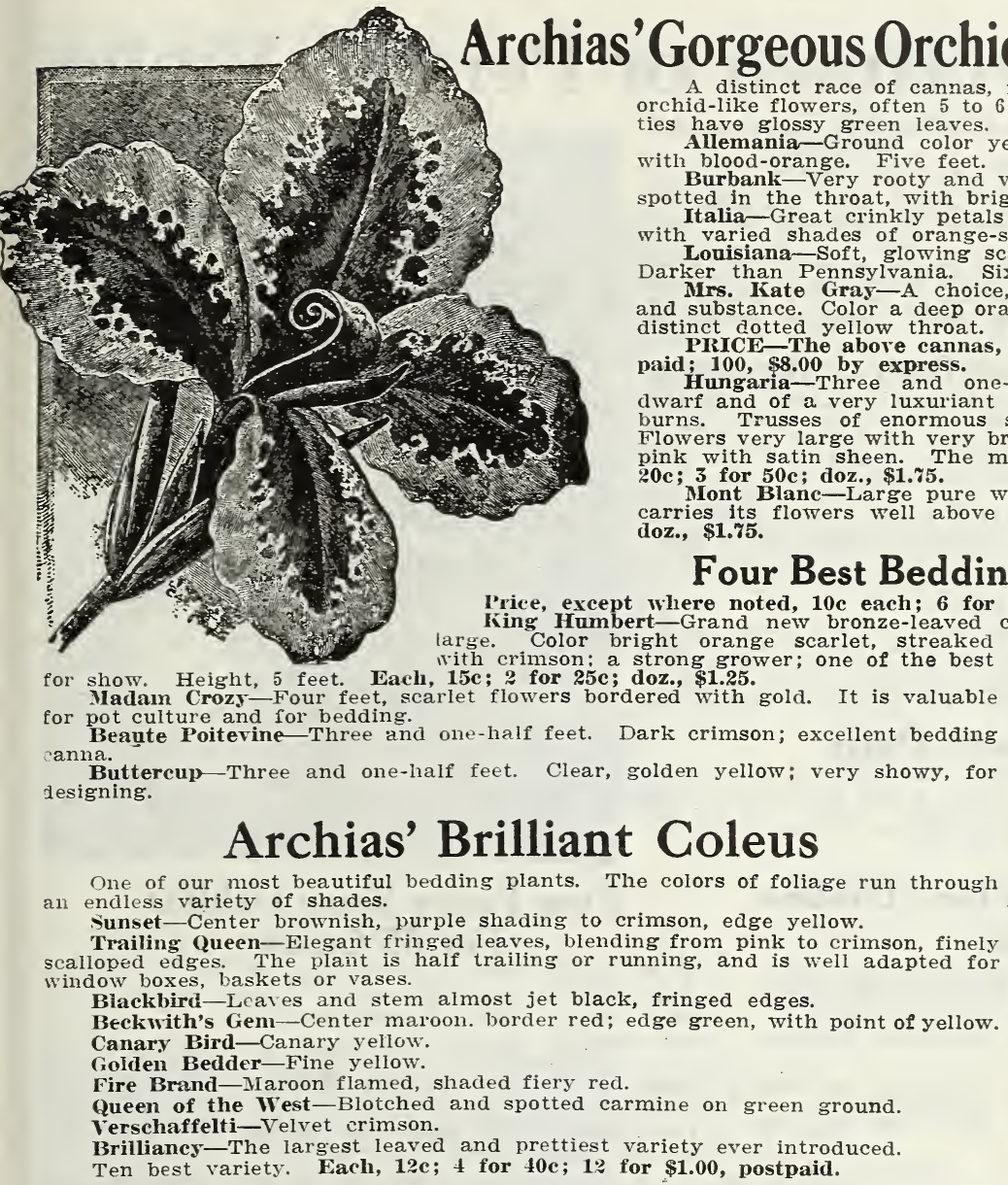

\section{Chrysanthemum Novelties}

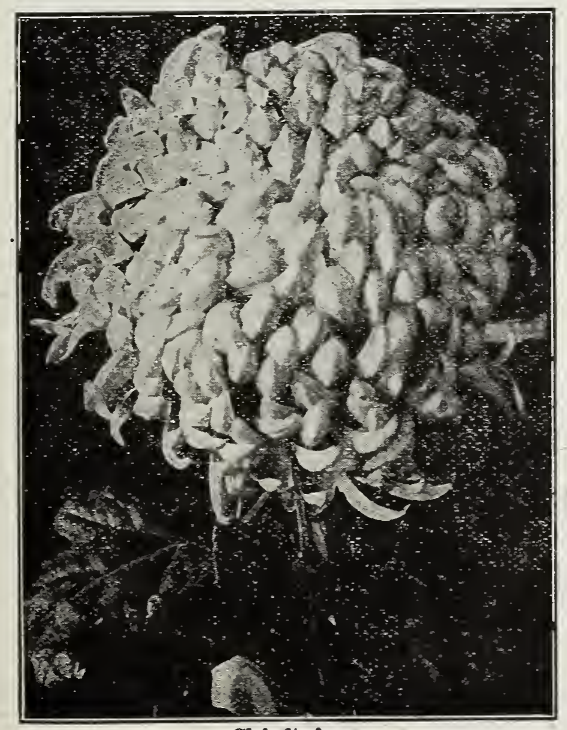

Chieftain

\section{Gold Medal Collection}

The four varieties offered below are the very latest and best introduction. They are selected from the prize winners of the late exhibitions. Price, each, 15c; 3 for $40 \mathrm{c}$; 6 for $75 \mathrm{c}$, postpaid.

Ruth Anne-An improved Linwood Hall. A glorious chrysanthemum, glistening snow white, largest size, perfectly incurved, elegant finish, mid-season. incurved variety. Color pure white. Has captured every cup and prize incurved variety. Color pure wh.

Which it has been entered. clear pink muardclear pink, much darker shade than any other listed. Incurved, with
broad petals, the lower ones drooping as the center opens. An exceedbroad petals, the lower ones drooping as the center opens. An exceodGolden Glow-A bright yellow of velvety finish, fine stem and foliage. Flowers $5 \frac{1}{2}$ inches in diameter, and fine form. The very best of early yellows.

\section{Seven Grand Show Chrysanthemums}

Below we offer a carefully selected list of choice varieties shown at the exhibitions last season. They are all very distinct and marked improvements over previous sorts. Price, any variety, 12c each; 3 for $30 \mathrm{c}$; 6 for $50 \mathrm{c}$; doz., 95c, postpaid.

Major Bonaffon-Yellow, incurved; petals large; second early. time. fect Chieftain-Beautiful incurved; flesh pink; very early and of perPacific Supreme (New) - A fine new seedling of Glory of the Pacific, its beautiful pink color intermediate between the shades of $\mathrm{Pa}$ cific and William Duckham.

Polly Rose-Extremely early; pure white.

Early Frost-The earliest blooming white mums are seldom large, but this variety is at once very early, and shows blossoms six inches and more in diameter. Its color is pure white, with creamy center. Mistletoe-Very large, pure white, strong
the latest. Blooms Dec. 1st until Christmas. 


\section{Archias' Cyclamen or Persian Violet}

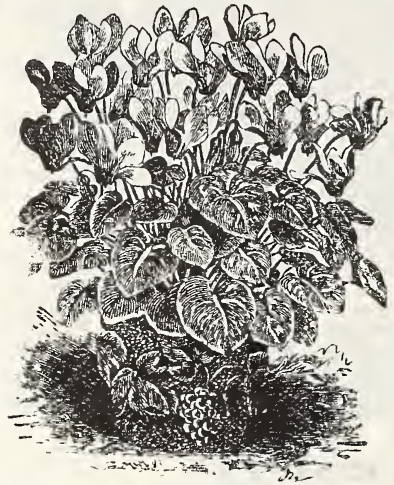

rieties go handsomely together, 1 "Oueen alexandra" (Ther, 15c each.

-Filors percentage coming full double, like an Anemone-flowered chrysanthemum, the semi-double and single flowers, on the same plant, are very handsome. Price, 15c each. The set of 3 Daisies, 35c.

\section{Improved Shasta Daisy}

Perfectly hardy, of easy cultivation, and blooms for several months. The flowers are large, averaging a foot or more in crimcumference, with broad petals of the purest white. One of $\mathrm{Mr}$. Burbank's productions. One foot. Blossoms from June to October. Each, 15c; 2 for $25 \mathrm{c}$; 12 for $\$ 1.25$.

\section{Three Gorgeous Decorative Dahlias For 50 Cents}

Jack Rose-Unquestionably the grandest crimson decorative dahlia color same as the famous Gen. Jacqueminot Rose; plant dwarf and will bear 40 to 50 blooms.

Clifford W. Burton-Canary yellow flowers of immense size and perfect form.

Sylvia-Flowers 4 to 6 inches in diameter on long stems; color white shaded soft pink; a good one.

Price, either of above, $20 \mathrm{c} ; 3$ for $50 \mathrm{c} ; 6$ for $80 \mathrm{c} ; 12$ for $\$ 1.50$, postpaid.

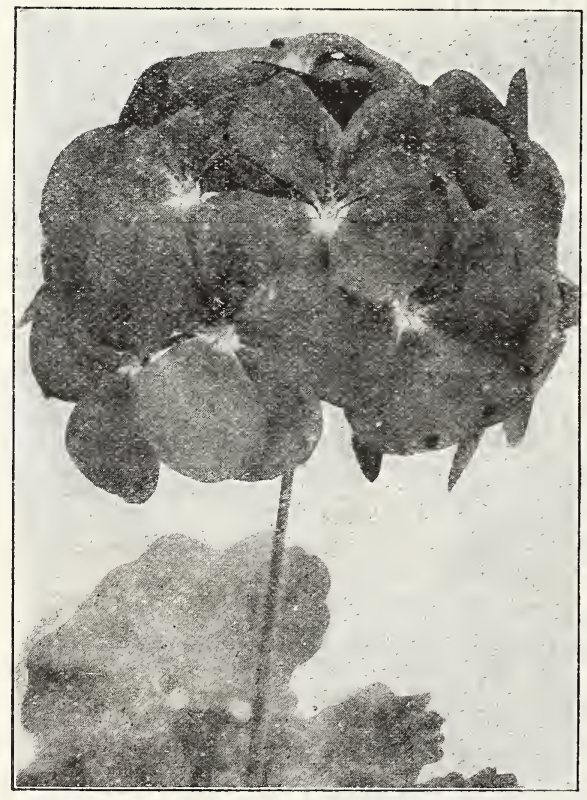

Four Exquisite Cactus Dahlias For 50 Cents

Fairy-A beautiful flower of light, airy form, of the purest

white. Aegir-Rich, bright, crimson scarlet, unique, distinct form.

Morning Glow-Soft golden yellow, tipped amber, large size.

Kriemhilde-Deep rosy pink, with lighter center; a handsome flower; good keeper.

Price, either above cactus Dahlias, each, 20c; 2 for 35c; 4 for $50 \mathrm{c} ; 12$ for $\$ 1.40$, postpaid.

MIXED DOUBLE DAHLIAS-Over 100 choice and valuable sorts, including many of last year's novelties in mixture unnamed, 10c each; 6 for 50c; $\$ 1.00$ per doz., postpaid. By express, at purchaser's expense, 75c per doz.; $\$ 6.00$ per 100.

\section{GERANIUMS}

of the best varieties. Each, 12c; 3 for 30c; 12 for $\$ 1.00$. Beaute Poitevine-Semi-double, salmon pink, shaded deep orange: immense size. Buckner-Double white flowers, large trusses. Profu

Jean Viaud-New rosy pink, white eye, semi-

Mrs. E. G. Hill-Fine, extra large trusses of exquisite bright salmon, white center

S. A. Nutt-Very best double dark crimson, scarlet bedders. Black Prince-Fine shade of dazzling crimson red; flowers in immense trusses on very long stems. Fine for bedding, single. Alphonse Ricard-Bright vermilion, scarlet. The trusses are so freely produced as to almost conceal the foliage; double.

\section{Sweet Scented Geraniums}

Including rose, two kinds, Mrs. Taylor and Apple, each, 12c: 3 for $30 c$.

\section{Ivy-Leaved Geraniums}

Galilee-Lovely rose-colored flowers.

Jean d'Arc-Largest and finest white in existence. Perfectly double; flowers literally cover the plant.

Charles Turner-Very double, without doubt the handsomest ivy geranium ever introduced; florets $2 \frac{1 / 2}{2}$ inches across. Color, bright scarlet.

Either of the above, 12c each, or set of 3 for $30 \mathrm{c}$. 


\section{BEAUTIFUL DECORATIVE FERNS}

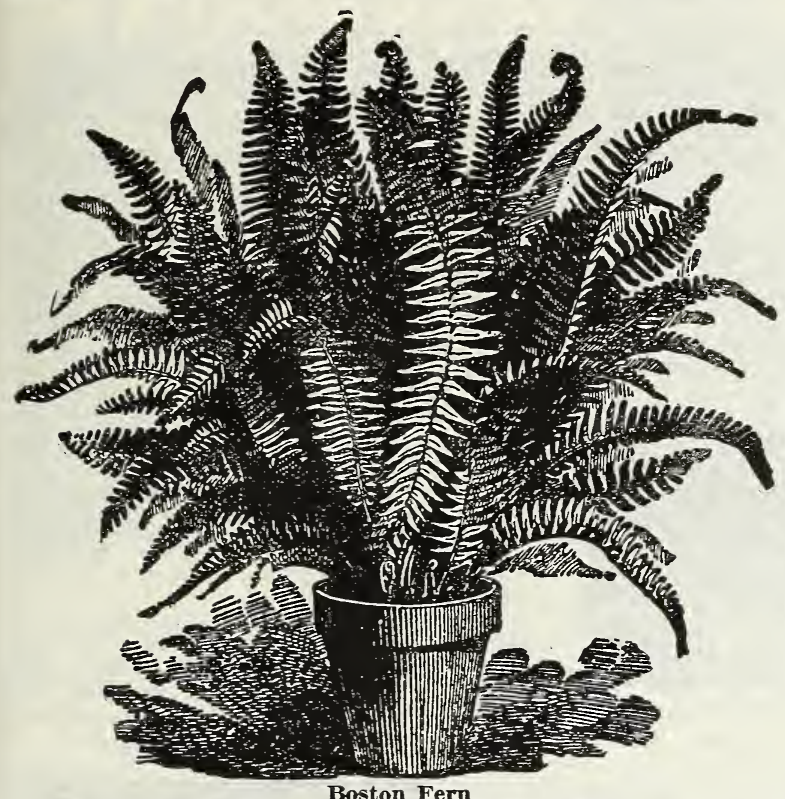

\section{The Best For Home and Porch Decorations}

Price, 20c each; 4 for $65 \mathrm{c}$; larger size, 25c to $\$ 1.00$ each;

Boston Fern-A most beautiful Fern for growing in pots, vases or baskets. It thrives under ordinary conditions, reThe fronds grow 2 to 3 feet long and arch in a graceful manner.

Anna Foster Fern-A beautiful new variety of the Boston petals are finely cut or divided

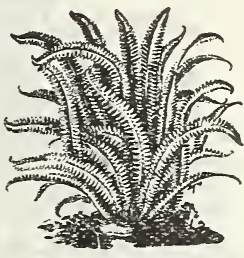

Sword Fern into tiny leaflets; a most beautiful and graceful effect. Each, 25c.

Scotti-Of more dwarf growth than Boston, and makes a handsome pot plant. A rapid grower and very hardy. Fach, 20c.

Sword Fern (Nephrolepis Evollatum)-Beautiful and grand.

Piersoni-New Ostrich Plume Fern; very popular form of Boston Fern. The pinnae subdividing making a mass of graceful, feathery plumes. Nothing de scribes them better than "Ostrich Plumes." Each, 20c. Whitmani- of the same feathery fronded type as the Piersoni, but more dwarf and lacy; very pretty.

Maiden Hair-For Fern dishes.

Lygodium Scandens-Creeping Fern.

\section{Hardy Ferns}

SUILL FERNS FOR FERN PANS

We have a very fine collection of small Ferns suitable for Fern Pans or Dishes. Nothing makes so fine an ornament for the dining table, and their use is now very general. Nothing finer or so well adapted fo the purpose. Each, 15c; dozen, \$1.25, postpaid.
The tendency towards natural gardening has brought many plants into prominence which had long been neglected; none are more deserving of this distinction than Hardy Ferns. Given a porous soil rich in humus, a shady or partially shaded position, and moisture, and they luxuriate, coming up year after year. We offer a choice seper dozen; $\$ 18.00$ per 100 . Set of five distinct sorts for $\$ 1$.

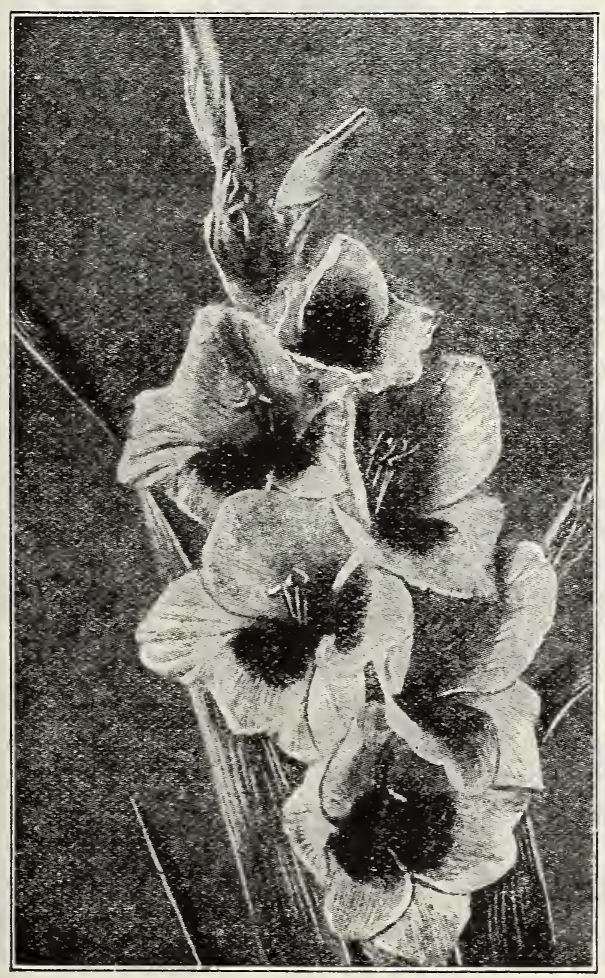

\section{THE BEST GLADIOLUS}

\section{Archias' New Prize-Winning Sorts}

The following varieties are selected from a long list of named gladiolus, and are without exception large flowering sorts. These bulbs will all bloom this coming season.

Mrs. Francis King-In color, a light scarlet, which attracts attention at once. The expanded flower is from 4 to 5 inches across, and 4 to 6 flowers are open at one time. The growth is vigorous and the bloom brilliant. 8c each; 75c per doz., postpaid.

Augusta-Pure white flower; blue anthers. 6c each; 65c per doz., post paid.

America-A beautiful soft shell pink color, tinged lavender growth and habit perfect; an ideal bedder. Flowers large and spreading, all facing one way. 8c each; 75c per doz., postpaid.

Independence-Light scarlet, large flowers on a stiff, straight spike. 8c each; 75c per doz., postpaid.

Klondike-Light yellow, crimson-maroon blotch. 6c each; 65e doz., prepaid.

For 25 cents we will send, by mail, postpaid, one bulb of each of the above five beautiful gladiolus, each distinctly ląbeled. Two sets ( 10 bulbs), for $45 c$, postpaid.

\section{Choice Gladiolus Mixture}

Our stock is produced by leading specialists and the most critical growers in the United States, as well as those we grow ourselves, hence improving in quality from year to year. Greater satisfaction, for the small outlay required, can hardly be obtained. All colors mixed, each, 5c; doz., 45c; 50 for $\$ 1.50 ; 100$ for $\$ 2.75$, postpaid. By express, 100 for $\$ 2.25$.

\section{Heliotropes}

Madame Bruant-Large purple, with white eye. Good bloomer. 2 for $25 \mathrm{c}$. 
GROW' "S U RE SEED S," PLA NTS A N D T E E S

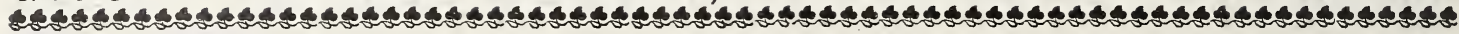

\section{Archias' Wonderful Ponderosa Lemon}

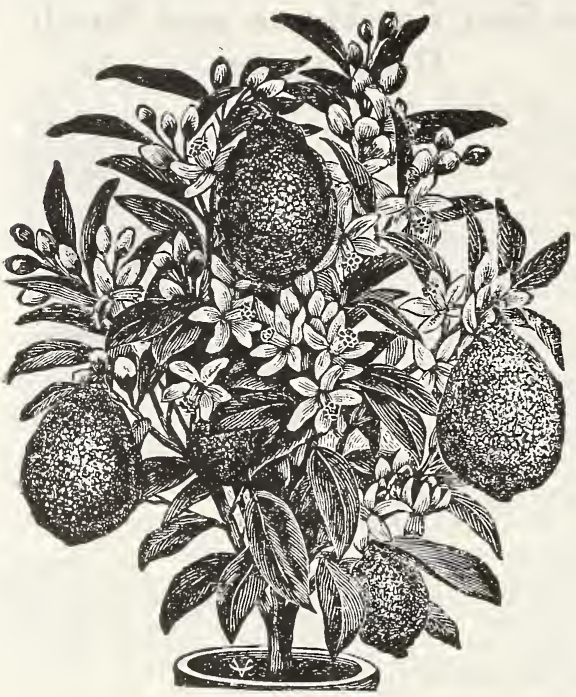

Ponderosa Lemon

Five or six times as large as the ordinary Lemon of commerce; of perfect shape and even ripening. Ponderosa represents the highest quality as a fruit, while the combination of flower, fragrance, fruit and tree-like growth makes it one of the grandest and most satisfactory window and porch decorative plants in existence.

Price, 20c each, postpaid. Larger plants, $35 \mathrm{c}$ to $50 \mathrm{c}$ each.

\section{Otaheite Orange}

A grand pot plant of great beauty and novelty. It is a dwarf orange that grows, blooms and fruits freely in pots, even when only a foot or two high. The blooms are produced in the greatest abundance, and very sweet. With one or two plants you can raise an abundance of fragrant flowers and oranges.

Price, $20 \mathrm{c}$ each. One Lemon and one Orange for $35 \mathrm{c}$, postpaid. Larger plants, $35 \mathrm{c}$ to $50 \mathrm{c}$ each.

\section{Lantanas}

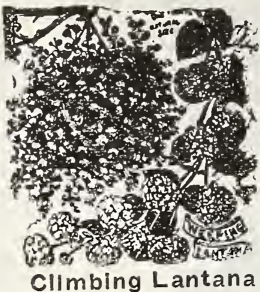

$20 \mathrm{c}$ each; 2 for $35 \mathrm{c}$. One of each of the 4 sorts for only 60 cents, postpaid.

Mrs. McKinley-The weeping Lantana. Clear pink flowers. It is a short trailer. especially suited to baskets, etc. Always n bloom.

Alba Perfecta-Immense trusses of pure snow white flowers.

Countess de Biencourt-Flowers bright rose and yellow, center sulphur.

Michael Schmidt-Flowers fresh an sparkling, of brilliant yellow passing into pink.

Kudzu Vine

(Jack and the Bean Stalk)-The most remarkable and rapid growing hardy perennial vine extant for covering porches, arbors, old trees, etc. Each, 15c; 2 for 25c; 6 for 60 c; 12 for $\$ 1.00$, postpaid.

\section{Maderia Vines}

The Maderia Vine is of rapid growth, with dense and beautiful foliage, twining to a great height. It grows anywhere, but does better in a warm, sunny, sheltered location.

postpald.

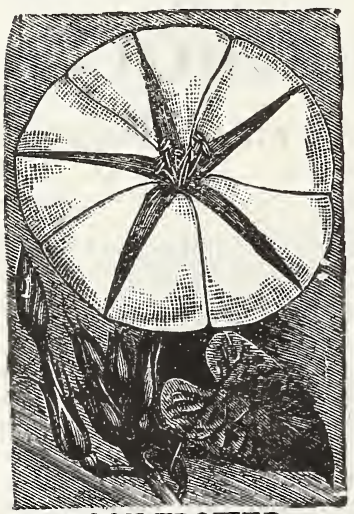

MOON HLOWER.

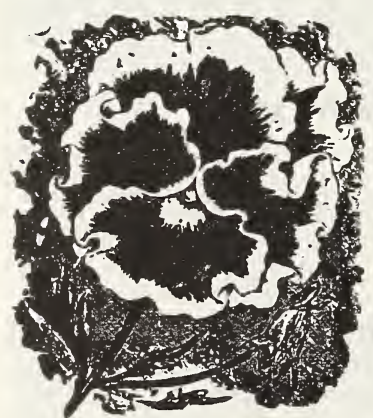

Giant

\section{Moonflower}

Wonderfully Fragrant

A decided improvement over the old Grandiflor The flowers are more than twice the size of the old variety and are produced in such wonderful profusion that they completely cover the vine with a veil of glistening white. Price, large growing plants, $15 \mathrm{c}$ each; two for 25c; $\$ 1.25$ per dozen, postpaid.

\section{Salvia, or Flowering Sage}

Three of the best varieties, either of the following, each, 10c; 3 for 25c; doz., 75c; 100 for $\$ 4.50$.

Splendens (Scarlet Sage)-Intensely rich, scarlet flowers that continue to bloom in profusion until frost.

Salvia, Drooping Spikes - Flowers are of brilliant dazzling scarlet, produced in fall.

Dwarf Everblooming Salvia Zurich -A fine scarlet, very dwarf and an ever-bloomer.

\section{Pansy Plants}

Favorites with everyone. Our plants are grown from our Fancy Strain. Best colors and finest forms. Strong plants, doz., 5c, postpaid. By express, doz., $40 \mathrm{c} ; 3 \mathrm{doz}$. for $\$ 1.00$.

\section{Mammoth Verbena Plants}

Finest varieties only; 6 for 30c; 12 for $50 \mathrm{c}$; 100 for $\$ 4.00$, postpaid.
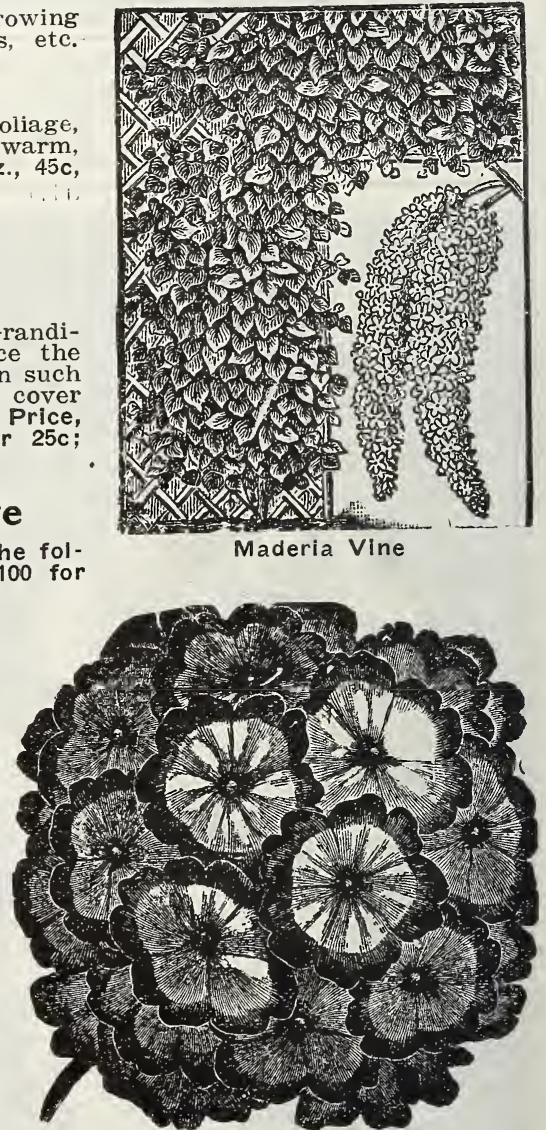

Mammoth Verbena 
A R C I A S ' SEED STORE, SEDALIA, MISSOURI

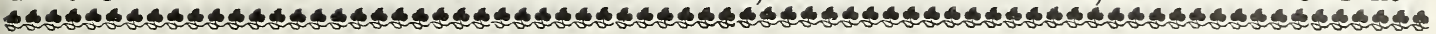
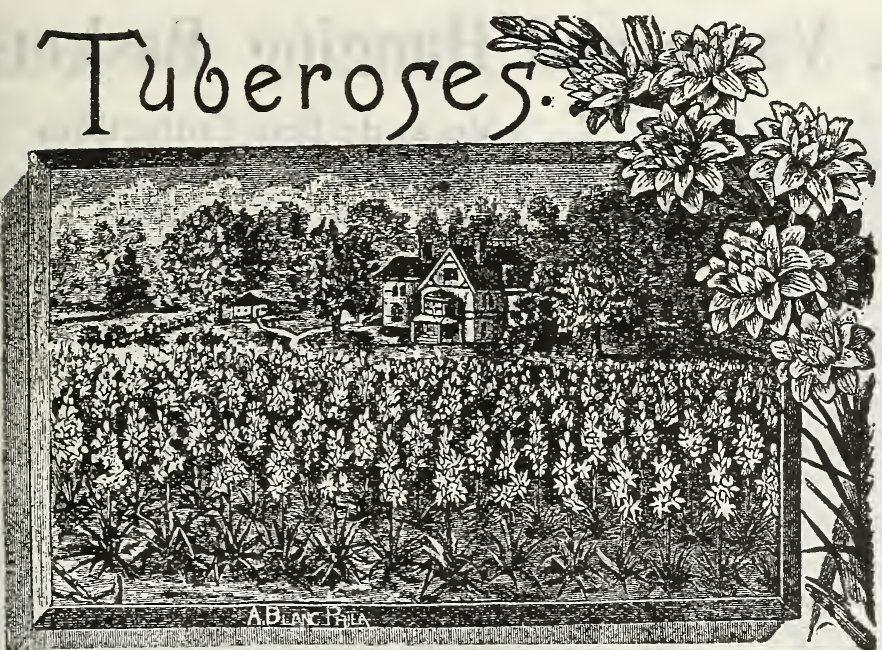

\section{Tritoma Pfitzerii}

A marvelous improvement over the well-known Red Hot Poker Plant. Large spikes of brilliant flame color. A border of it around cannas or caladiums makes a brilliant contrast. Hardy with protection. Each, 25c; 5 for $\$ 1.00 ; 12$ for $\$ 2.00$.

Bargain Collection of 25 Choice Summer Flowering Bulbs, \$1.25.

1 Begonia, double; 1 Begonia, single; 1 Calla Lily; 1 Caladium; Cinnamon Vines; 6 Oxalis, mixed; 1 Maderia Vine; 3 Tuberoses; 2 Canna, Dwarf; 1 Dahlia, double; 6 Gladiola, mixed. Labeled, carefully packed and guaranteed to reach the buyer in good condition. We make this remarkably liberal offer to introduce our special Flowering this low price.

Extra! With every dollar for this collection, we will include a FREE package of a New Pansy. Please ask for it with your order. Add a liberal supply of Summer Flowering Bulbs to your order. Plenty of nice flowers make a bright, cheerful home.

\section{Sanservia Zelanica (Snake Plant)}

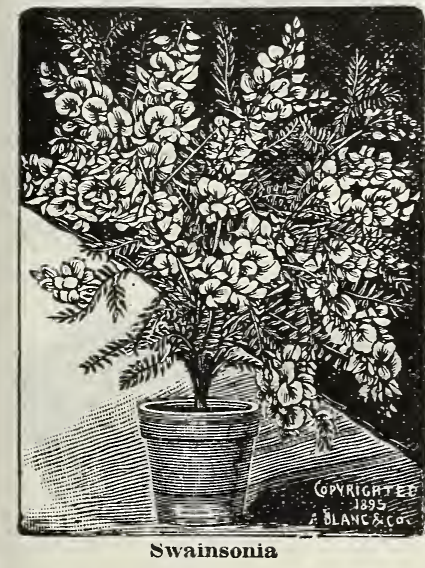

A singular pla $n t$ eminently adapted for decorative purposes in parlors, etc. Erect, rigid, s w o r d - 1 i k leaves, dark green. beautifully st riped crosswise with white, and flower's wh 1 t e. Eacli, 25c. Iarge size, 50c.

\section{Swainsonia Alba} borne in clusters of 10 to 20 flowers each resembling Sweet Peas, produced in great profusion: color $\mathrm{p} \mathrm{u} \mathrm{re}$ white. A very valuable plant for house uable plant for house for $25 \mathrm{e}$.
The flowers a r e

\section{WHY WE SUCCEED}

Our Mr. L. H. Archias and Mr. L. A. Kipping devote their entire time to the growing, selecting and selling of the very choicest varieties of "SURE SFEDS, PLANTS, BULBS AND TREES," and with the aid of competent assistants who have your interest at heart, we are ready to furnish only that which has been proven THE BEST by actual test Note that our descriptions are brief, avoiding exaggeration and strictly adhere to facts. THERE IS A REASON

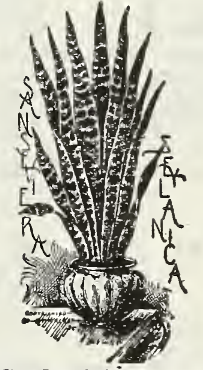

\section{Large-Flowering Single Violets}

Princess of Wales - A grand variety, rich violet, intensely fragrant. Price, 10c each; $\$ 1.00$ per dozen.

\section{Wandering Jew \\ (Tradescantia Multicolor)}

Most beautifully variegated purple, scarlet and white. Price, 10c each; $\$ 1.00$ per dozen, postpaid.

\section{Umbrella Plant}

\section{CYPERUS}

This is a plant of the easiest culture and a large specimen; is as handsome as a palm for decoration. It will grow luxuriantly in water and is therefore indispensable for aquariums or fountains. Each, 15c; 3 for $40 \mathrm{c}$.

\section{Archias' Fragrant Col- lection of Flower- ing Plants}

One Sweet Violet, 2 Fragrant Heliotropes, 2 Scented Geraniums, 3 Tea Roses and 3 exquisite Carnations, $\$ 1.00$, postpaid.

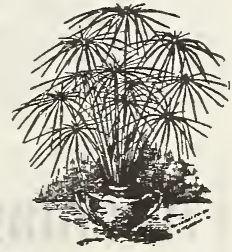

Umbrella Plant 
GR O W "S UR E SEE D S,' PLA N.T S A N D T R E S

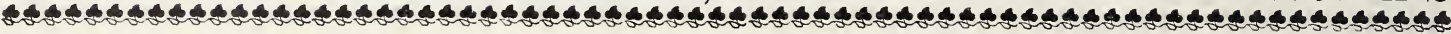

\section{For Porch Boxes, Vases and Hanging Baskets}

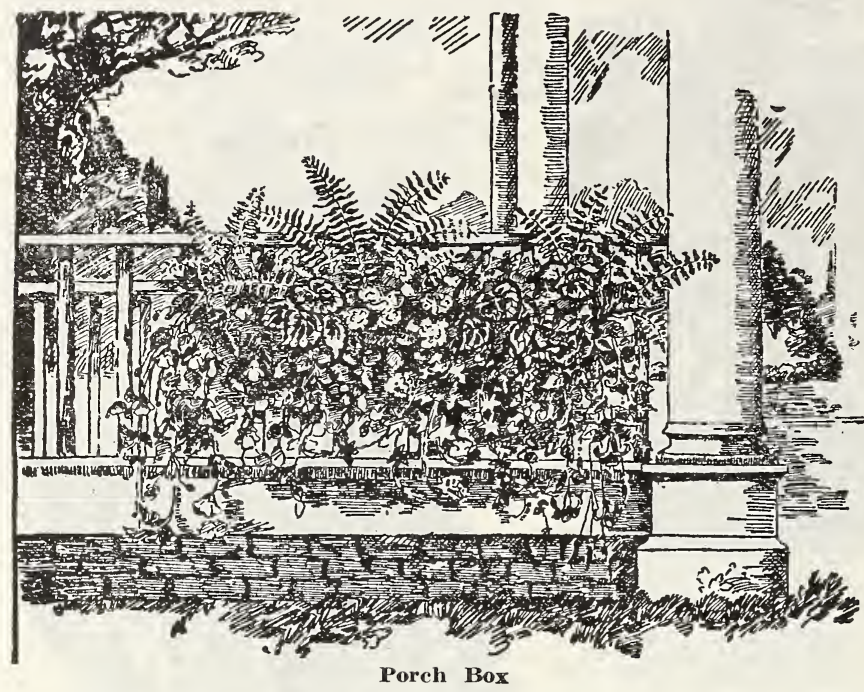

\section{Veranda Box Collections}

We have selected the following plants because they are the most satisfactory for the purpose. This collection contains enough plants for a 3 foot box, or an ordinary window. We will supply this Veranda Box Collection of fifteen plants for $\$ 1.00$, or we will supply two collections, enough for a 6-foot box, or a large or twin window for $\$ 1.75$.

Two Begonias-Brilliant flowers; handsome foliage.

One Russelia-Fine grass-like foliage and small flowers.

Two Parlor Ivy-Climbing habit; yellow flowers.

One Acalypha-Beautiful ornamental foliage.

One Pilea-Fine moss-like foliage; small flowers.

Two Geraniums-The best scarlet varieties.

One Abutilon-Beautiful weeping variety.

One Vinca Variegated-Foliage green, margined white.

One Weeping Lantana-A wonderfullv profuse bloomer.

One Tradescantia-Grand drooping plants; green and bronze foliage.

Two Verbenas-Always in bloom.

\section{The "Sunnyside" Porch Box Collection, $\$ 1.75$}

A selection of plants for sunny locations.

2 Coleus, different sorts.

2 Fuschsias, different sorts.

4 Geraniums, different sorts.

4 Lantanas, different sorts.

2 Salvias.

4 Petunias, different colors.

SPLCIAL-One-half of above collection, same assol $t$ ment, but one-half the number of each lind, for 90c, postpaid.

\section{Vase Collection No. 1}

This collection will be made up as follows: 1 Canna for center, 4 large Geraniums, 2 large Begonias, 3 Petunias 3 bright Coleus, 1 Dracena Indivisa, 2 Impatiens, 1 Roya Purple, 1 Croton, and for border, 3 Asparagus Sprengeri and 6 Variegated Vincas. This collection will fill a vase from 15 to 18 inches in diameter, and we will send it to you by express for \$2.25. In ordering please asl for $\$ 2.25$ Vase Collection.

\section{The "Shadyside" Porch Box Collection, $\$ 1.50$}

A selection of plants for shady locations.

2 Asparagus Sprengeri and Plumesus.

2 Flowering Begonias, different sorts.

2 Umbrella Plants.

2 Ferns, Boston and Ostrich Plume.

4 Heliotropes, two colors.

2 Violets, different sorts.

SPECIAL-One-half of above collection, one-half the number of each kind for 80c, postpaid.

\section{Vase Collection No. 2}

For \$3.25 we will increase the number of plants in this collection to fill a case from eighteen to twenty-four
inches in diameter. In ordering please ask for the $\$ 3.25$ Vase Collection.

Place your confidence in us for satisfactorily filling these collections, and we will not disappoint you.

\section{Archias' "Ideal" Self-Watering Flower Box}

Archias' "Ideal" Self Watering Flower Box-Designed to meet a long felt want and to overcome many objections to wooden boxes and other types of metal boxes, as well as to meet the requirements of the plant itself.

Archias' Ideal Flower Box has a double wall. The air space between the outer and inner walls keeps the inner wall cool, the dirt will not dry out and roots become baked. You ary out and roots become the top of the box. A channel runs the entire length of the box in the center. This system makes watering easy, regardless of where the box is. Over-watering plants is as detrimental as not watering enough. The Ideal has a method of drainage which prevents giving the plants an over-supply.

Archias' Ideal Flower Box, in addition to being the ideal window box for summer use, is also the ideal box for indoor use in winter. You can give this box plenty of water and at the same time not get any on the floor.

What is more, you can place enough water in the box to last several days without attention. Each box is made $81 / 4$ inches wide, $61 / 2$ inches deep.

Price, 24 in. long, each, \$1.75; 2 for $\$ 3.25$.

Price, 30 in. long, each, $\$ 2.00$; 2 for $\$ 3.75$.

Price, 36 in. long, each, $\$ 2.50$; 2 for $\$ 4.75$.

Price, 48 in. long, each $\$ 3.00$; 2 for $\$ 5.75$.

\section{Archias' Flower Seeds are of the Highest Quality}




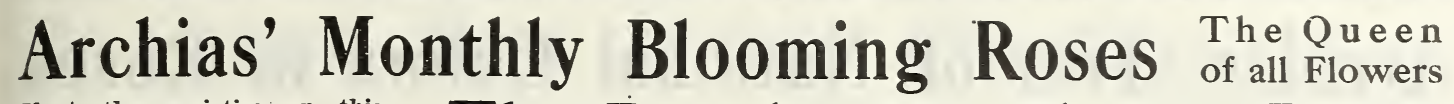
Plant the varieties on this page for long-stemmed flowThe Popular Cut-Flower Roses

ers for home decoration.

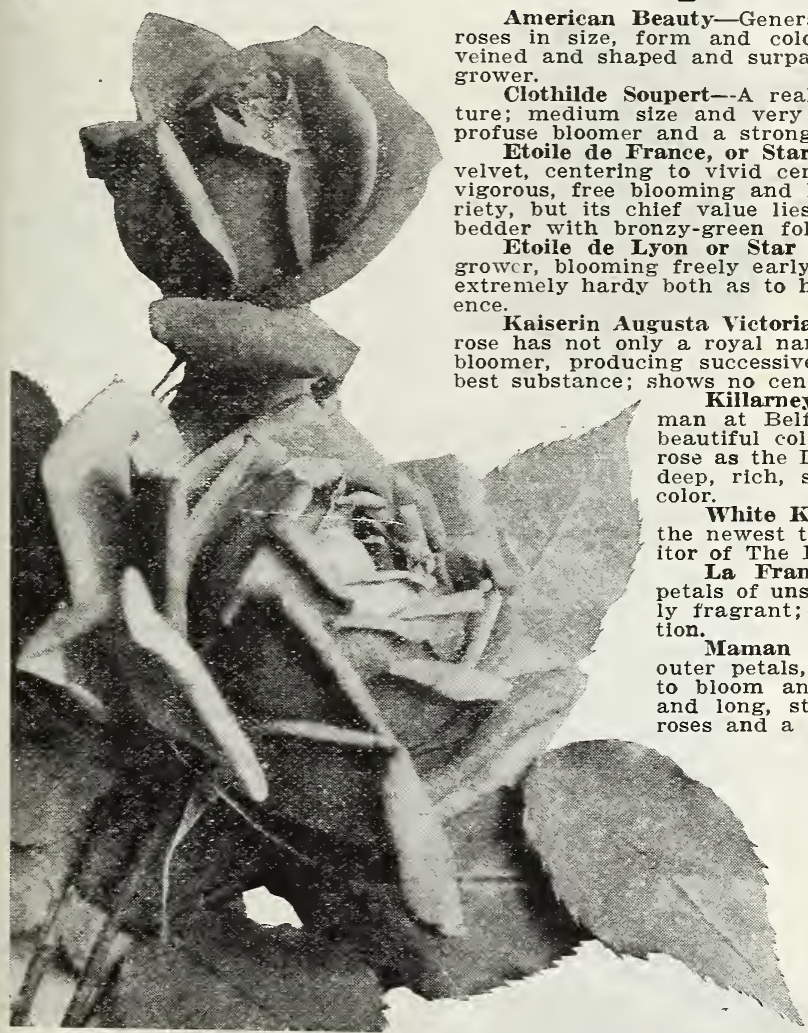
ed with bronzy-green follage.

conceded to be the most grandly beautiful of
Rich red, passing to crimson, very delicately roses in size, form and color. Rich red, passing to crimson, very delicately Clothilde Soupert--A really wonderful rose for bedding out or for pot culture; medium size and very double; white, shading to deep pink at center; a profuse bloomer and a strong dwarf grower, deliciously fragrant. velvet, centering to vivid cerise; large flowers on long stiff stems; remarkably vigorous, free blooming and hardy. Grown to soine extent as a cut flower va-

Etoile de Lyon or Star of Lyon-Deep golden-yellow; a healthy, vigorous growcr, blooming freely early and late; full, deep and rich flowers, very sweet; heat and cold. One of the best bush roses in existKaiserin Augusta Victoria-The best white rose in the world. This beautiful rose has not only a royal name, but is a royal rose as well. It is a continuous bloomer, producing successive crops of buds, and formed with large petals of no center when fully open.

rose, raised by an Irish-

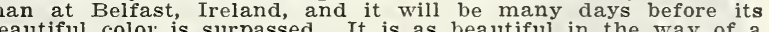
rose as the Lakes of Killarney are as to a body of water. Clear. ep, rich, shell-pink; some describe it as crushed strawberry

hite Killarney-A pure white sport from the pink parent, nest thing in a forcing rose, admittedly a strong compet unsurpassable beauty; large symmetrical and delicious Maman Cochet-Rich, rosy-pink, shaded silvery-rose on
uter petals, exquisite in color and graceful in form from bud to bloom and delightfully fragrant; beautiful, healthy foliage and long, stiff stems. Unquestionably the queen of pink tea ading cut-flower variety.

White Maman Cochet-Very large and beautifully formed in bud and bloom; pure waxy white under glass, taking on a faint pink flush out of doors, which enhances its beauty. Vigorous and produces abundantly for cutting. Sunburst-A truly great rose which is now classed with the American Beauty and Killarney. It rivals Mrs. Aaron Ward, being a rich, coppery yellow of good size and form. Is a strong power, and having long, strong stems, is very fine for and having

Princess Bonnie-Similar to Richmond in color, but far richer in the bud. Large and double, opening perfectly at all seasons of the year. In form and fragrance it resembles General Jacqueminot.

Strong and sturdy in habit, with excellent foliage. Is strongly recommended for these qualities and also for its great productiveness and wonderful keeping qualities.

Price of any of the above famous cut flower roses: Strong, 2-yearold plants, each, 35c; 3 for $\$ 1.00 ; 6$ for $\$ 1.75$, or the set of 12 for only \$3.25, postpaid.

\section{Three Baby Rambler Roses}

\section{THREE BEST BEDDING ROSES EVER INTRODUCED}

Price for the following 2-year-old plants: Each, 35c; 3 for \$1.00; 12 for $\$ 3.25$, postpaid.

Crimson Baby Rambler-Most popular bedding rose in existence; it produces large trusses of bright crimson flowers; similar to Crimson Rambler, but instead of climbing it grows but 18 inches high and blooms the entire summer. Is equally good for winter blooming.

New Pink Baby Rambler, Baby Dorothy-Same freedom of bloom and perfect hardiness of the above, and greatly admired. Each, 15e.

White Baby Rambler (True)-Our White Baby Rambler came from a prominent German grower; and is as free bloomer as the other two "Baby" roses, producing magnificent white flowers in great abundance.

For other choice roses, see page 64 and 65 .

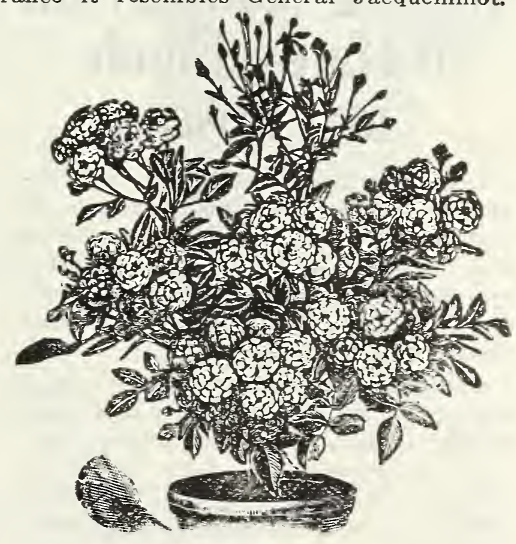

Baby Rambler Rose

\section{Archias' Ever Blooming Tender Climbing Roses}

Grand Roses for the South and the Pacific Slope, where they are entirely hardy. They may be kept outdoors in the North by laying them down and covering with leaves or litter.

One strong plant of each of the 4 sorts, postpaid, for only $\$ 1.15$.

This class is very satisfactory as free blooming Roses: hardy, but in for Northern sections requiring 4 to 6 inches of covering at the roots during the winter.

Climbing Soupert-A climbing offspring of Clothidle Soupert, with the same beauty and vigor. Ivory white, with silver rose center.
Mrs. Robert Peary-New; rich, creamy white, tinted

Marechal Niel-Exquisitely beautiful, large round flow ers of deepest yellow. Fragrant.

Empress of China-A strong growing rose, growing to a height of 15 to 25 feet in a single season. Produces throughout the season hundreds of handsomely formed lighter red or pink.

Any of the above, extra strong, 2-year-old, 35e each; 3 for $\$ 1.00 ; 6$ for $\$ 1.75 ; 12$ for $\$ 3.25$, postpaid. 
GROW "SURE SEEDS," PLANTSA A D T RE S

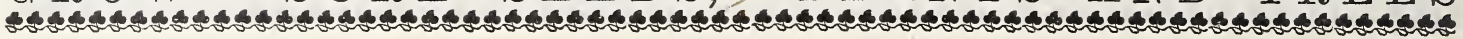

\section{Archias' Trio of National Colors in Roses}

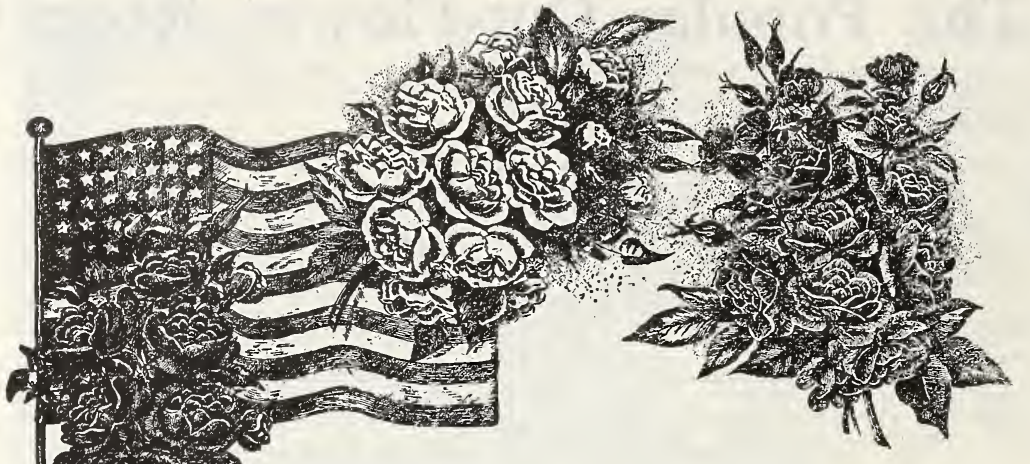

THE RED, WHITE AND BLUE RAMBLERS

Scientific Hybridization has produced, through methods past the understanding of the average worker among flowers, a new Rose which can easily be said to be the most novel creation of the century. No one pretends that it is the last word in Blue Roses, but it may be fairly described as an epochmaking variety, for no variety approaches it! It is a new freak among Roses, and quite distinct.

THE POPULAR CRIMSON RAMBLER

Of a very vigorous growth, making shoots from eight to ten feet during the season. It is also magnificent in bush form; color is the brightest crimson. The flowers are produced in great pyramidal panicles, the individued flowers measuring about one to one and one-half inches in diameter. The foliage is a bright green and glossy, and contrasts finely with the bright crimson of the flowers. Price, 2-year strong plants, each $35 \mathrm{c}$; 3 for $\$ 1.00$.

White Dorothy-A fine, hardy climber of the Dorothy Perkins type. We believe it is a better Rose in many respects than that variety. It bears double pure white flowers in immense panicles. By far the best white hardy Rose yet sent out. Price, 2-year strong plants, each $35 \mathrm{c} ; 3$ for $\$ 1.00$.

THE BLUE RAMBLER, Beilchenblau, Violet Blue The new rambler, "Veilchenblau" (Violet Blue), which is hailed by the German Rose growers as the forerunner of a genuinely cornflower blue Rose, is a seedling of Crimson Rambler. The blossoms, massed in large umbels, are semi-double, of medium size.

\section{ARCHIAS' Superb Collection of Hardy Climb- ing Roses}

Gruss an Teplitz, Greeting to TepIItz, or Virginia R. Coxe-Hardy in all sections; grows freely to a height of four to five feet; vivid, dazzling, fiery crimson; sweetly fragrant; produces a mass of gorgeous blooms on long stems.

Dorothy Perkins-Beautiful shellpink color, which holds for a long time, fading finally to a lovely deep rose; very sweet-scented; fully equal to Crimson Rambler in foliage, hardiness, habit of growth and blooming qualities.

Flower of Fairfield (The EverBlooming Crimson Rambler)-Commences to bloom in early spring and lasts till fall; more brilliant than Crimson Rambler. Blooms in large clusters; has shining green foliage, free from mildew. In all a most remarkable rose. Order early, as we predict a demand beyond our supply.

Two-year-old, extra strong plants, each, 35c; 3 for $\$ 1.00$; 5 for $\$ 1.50 ; 8$ for $\$ 2.00$.

The color, on first unfolding, is either reddish pink or purplish pink, then turns amethyst, and finally steel blue as the flower fades. The general color impression is that of the March Violet. The yellow stamens appear in sharp contrast to the blue petals. Price, 2-year strong plants, each $35 \mathrm{c} ; 3$ for $\$ 1.00$.

Everybody should have a national trio set of Climbing Roses on their porch, trellis or pergola.

Price, set of 3,2-year extra strong plants for only $\$ 1.00$, postpaid; 2 sets (6), for $\$ 1.75$. Order early.

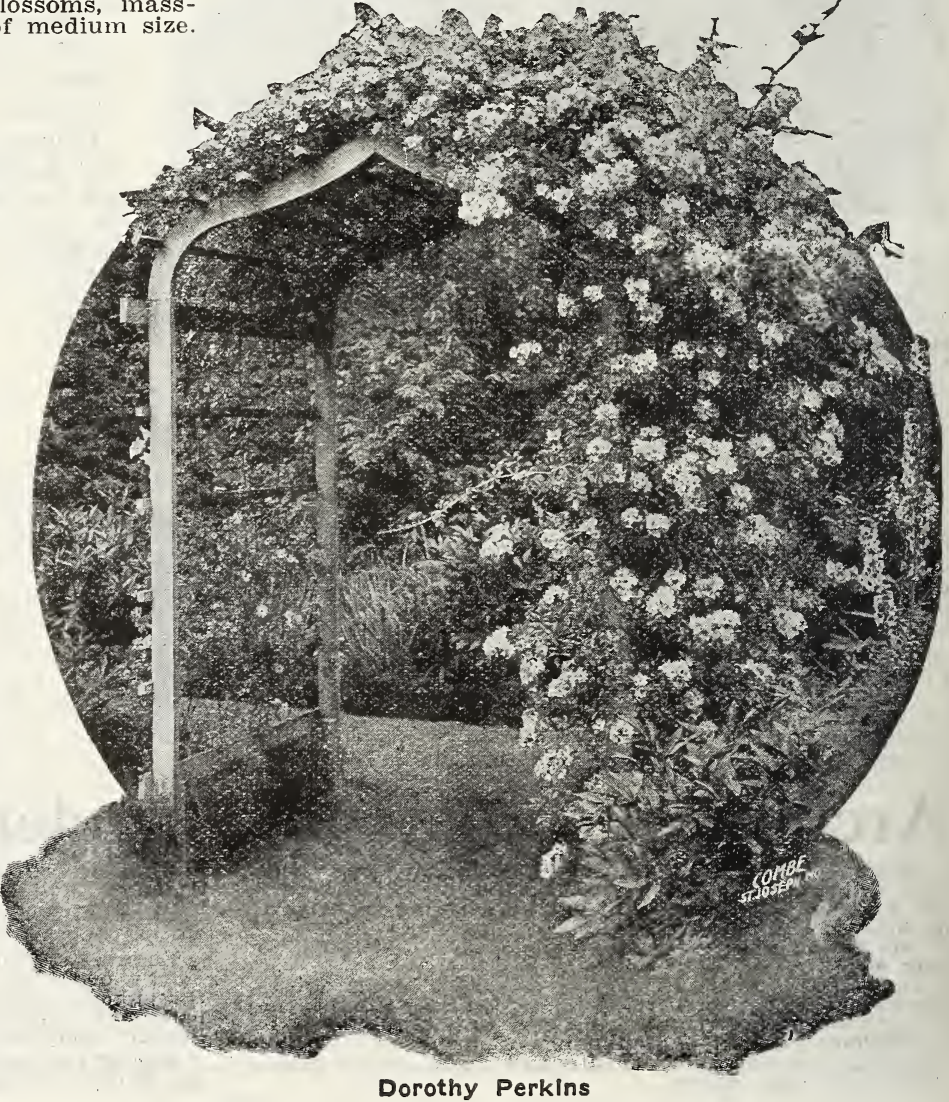




\section{A Grand New Hardy Climbing Rose}

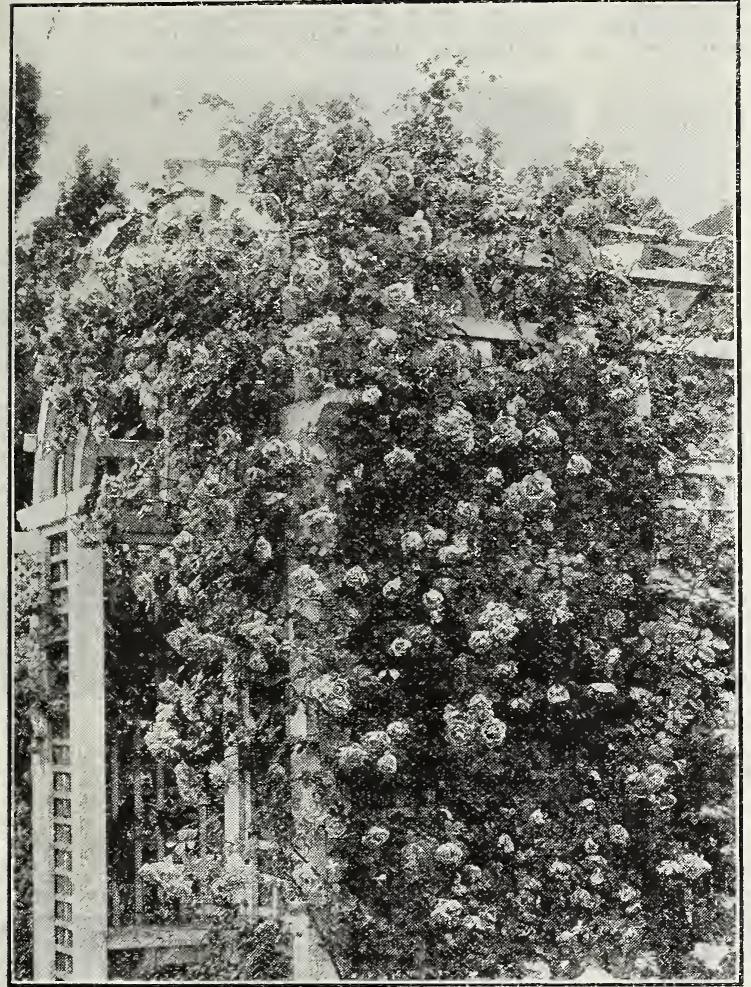

Climbing American Beauty

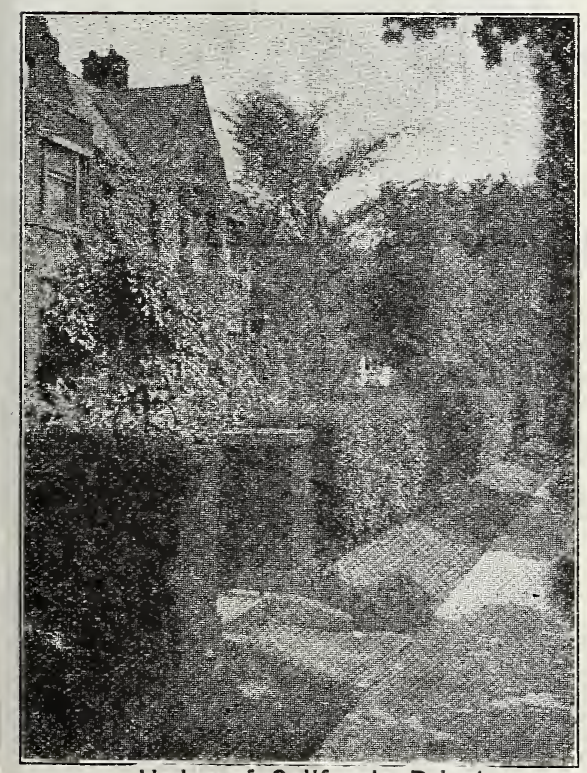

Hedge of California Privet ular.

\section{Climbing American Beauty}

A NEW ROSE of wonderful beauty and merit. A cross between the American Beauty and an unnamed seedling. Color rosy crimson, identical with its pollen parent, American Beauty, and with the same exquisite fragrance, a quality rarely found in the Climbing Roses. Of strong habit of growth, making shoots from ten to fifteen feet in one season; hardy as an oak. Will thrive and bloom in almost any situation where a climbing or pillar rose is desired. Flowers are three to four inches in diameter, finely formed, on long: stems and are produced in great profusion. The foliage is large, deep green and entirely free from black spot or mildew. One of the first Roses to bloom in the spring. Comes into flower with us the latter part of May and the first week in June, and continues in full flower for a month or more, with occasional bloom during the growing season; the plants, with us, having buds and flowers when nipped by frost in November. A rose of decided merit. (See Cut). Price, strong 2-year plants, each, $50 \mathrm{c} ; 3$ for $\$ 1.25$.

\section{Four Choice Tree Roses}

Roses in tree form are very showy, and as they occupy but very little ground space may be planted among other bush varieties or used along walks, etc., when they produce a very fine effect. We offer only the best and most tried varieties.

Fra $\mathrm{K}$ a r I Druschki-This is an ideal variety, blossoms pure white and is constantly in bloom.

Crimson Baby Rambler-The continuous bloom and perfect hardiness has made it very pop-

Gruss an Teplitz-One of the reddest of roses, fragrant and free blooming, very fine.

Magna Charta-A great favorite among roses. Color a beautiful bright pink, suffused with carmine.

Price, extra select trees, bloom profusely first season, each, $\$ 1.00$; set of 4 for $\$ 3.50$; 12 for $\$ 10.00$.

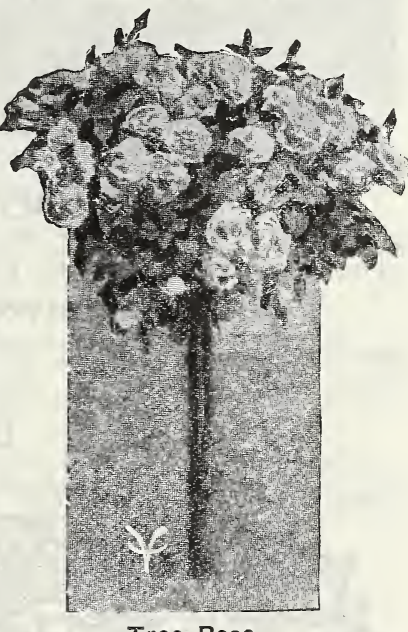

Tree Rose

Frau Karl Druschki

\section{California Privet}

Unsurpassed for hedges. The foliage is a handsome shade of deep green and almost evergreen. Splendid as a hedge between city lots or on large estates, as it will stand an immense amount of wind. Will grow to a height of 6 feet, but can be pruned down very easily. The more it is cut back the thicker and more handsome it grows. Price, 2 to 3 feet high, doz., $\$ 1.00$; 25 for $\$ 1.50 ; 100$ for $\$ 5.50$.

Amoor River (L. Amurense)-Of similar form and habit to the California type, with shinier foliage and reputed to be hardier. Two to 3 feet high, doz., \$1.25; 25 for $\$ 2.00 ; 100$ for $\$ 7.50$. 
GROW " $\mathrm{R} \mathrm{URE} \mathrm{SEE} \mathrm{D} \mathrm{S,"} \mathrm{PLA} \mathrm{N} \mathrm{T} \mathrm{A} \mathrm{N} \mathrm{D} \mathrm{T} \mathrm{RES}$

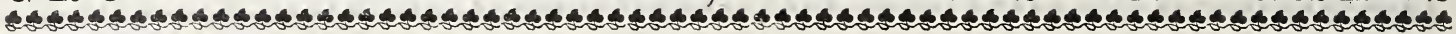

\section{Archias' Hardy Perennial Plants}

Plants of this kind are perfectly hardy in the open ground. They die down to the ground, but only to the ground, in the winter. Once planted they are a lasting pleasure. Failure in them is practically impossible. OrAchillea

Ptarmica fl. pl. "The Pearl"-The great cemetery plant. A single plant of archillea will produce hundreds of flowers the first season, 500 perfect flowers on the plant at one time. It commences to double flowers during the balance of tlie season. 15c each; 2 for $25 \mathrm{c} ; \$ 1.50$ per doz.

\section{Aquilegia Coerulea}

Rocky Mountain Columbine-One of the very best of the whole family; blue and white. Old favorites. Bloom late in spring. Each, 15c; doz., \$1.50.

\section{Bleeding Heart}

Dielytra Spectabilis-Pretty spring bloomers, with graceful drooping sprays of heart-shaped pink and white flowers. Each, 20c; 2 for $35 \mathrm{c} ; 6$ for $75 \mathrm{c}$

Campanula or Canterbury Bells

old-time favorites, with showy flowers of different colors, most

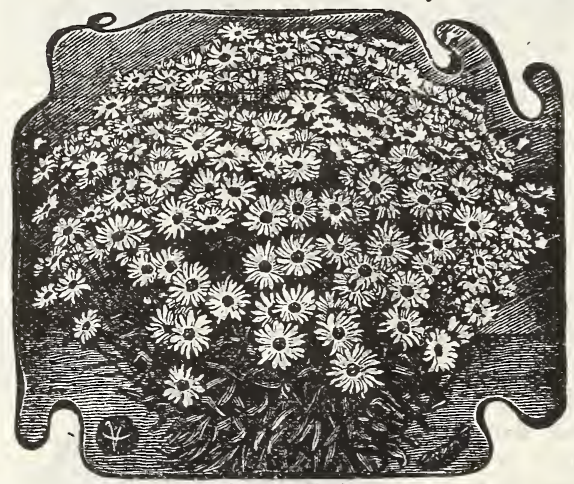

Shasta Daisy of them in shades of blue. Planted in beds or among shrubbery they lend color to surroundings. One of the most desirable of all hardy plants; state$1 \mathrm{y}$, free-flowering mental.

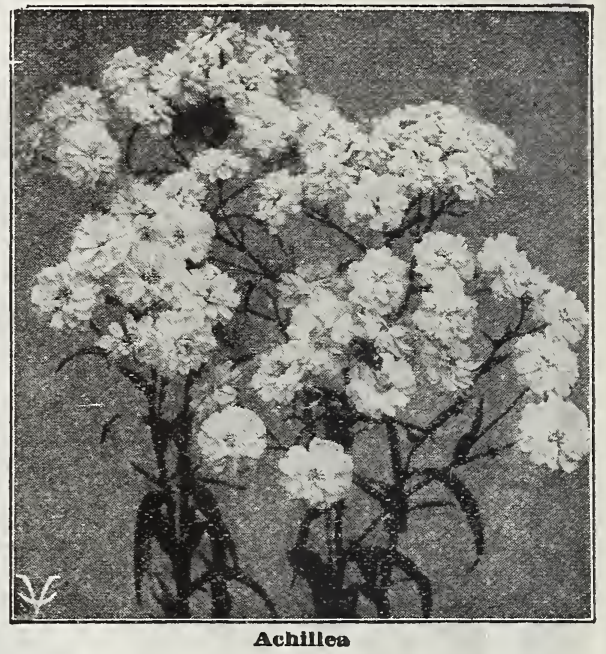

Calycanthema (Cup and Saucer)-Large blue, white or purple flowers. Wach, 15c; 2 for 25c; 6 for 60c; doz., \$1.00.

\section{Carnations}

(Hardy Grenadin)

We have a very nice stock of these free-flowering and fragrant garden carnations. With a littlo protection they are hardy everyWrere. Flowers are large. $25 \mathrm{c}$; doz., \$1.25.

\section{Chrysanthemums}

(Hardy Pompon)-These fine small flowered varieties are very popular for outdoor bedding; are quite hardy, requiring only a slight covering during winter. Each, 15c; 2 for $25 \mathrm{c} ; 6$ for $60 \mathrm{c} ; 12$ for $\$ 1.00$, postpaid.

\section{Improved Shasta Daisy}

Perfectly hardy, of easy cultivation, and blooms for several months. The flowers are large, averaging a foot or more in circumference, with broad petals of the purest white. One of Mr. Burbank's productions. One foot; June to October. Each, 15c; 2 for $25 \mathrm{c}$; 12 for $\$ 1.25$.

\section{Digitalis}

Gloxinoides-The strong flower stalks rising from rich and luxurious massses of leaves give an elegant appearance to the hardy border. Mixed

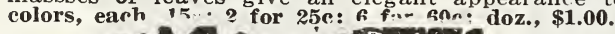

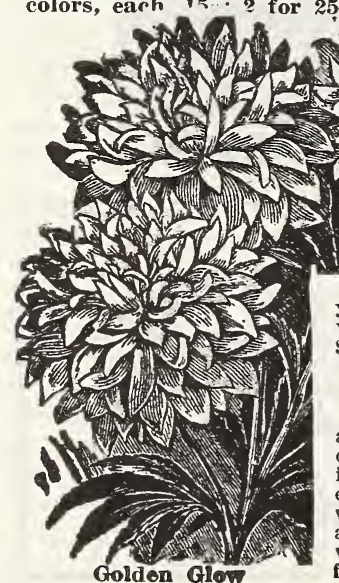

Golden Glow
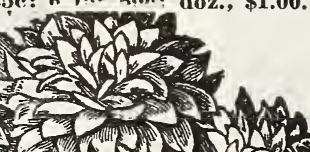
(4) loom in July, and com41.5 sact, 4 to 7 feet, continuing until killed by frost. The plant is high, proladen with double goldenyellow flowers, excellent for cut flowers, lasting well $\$ 1.00$, postpaid.

\section{Double Hollyhocks}

The most majestic of all hardy herbaceous plants, always attracting attention. Should be in every garden and dooryard, no matter how small. For planting in masses by itself, or as a background for lower growing plants the hollyhock cannot be dispensed with. we offer only the finest double varieties in white, pink, red and yellow. Price, 15c each; three for 50c; doz., $\$ 1.50$, postpaid.

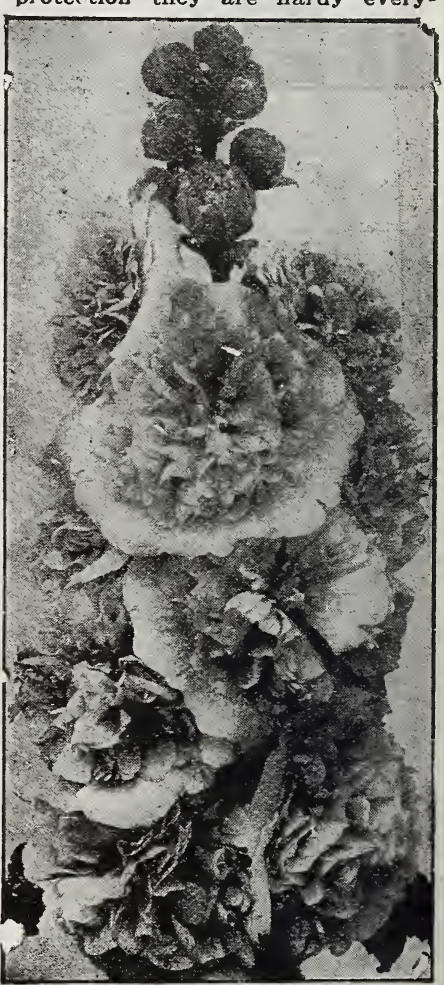

Double Hollyhock 
A R C I A S SEED STORE, SEDALIA, MISSOURI

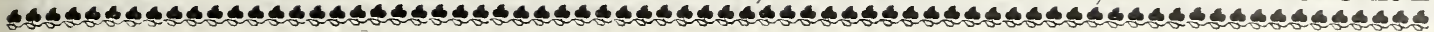

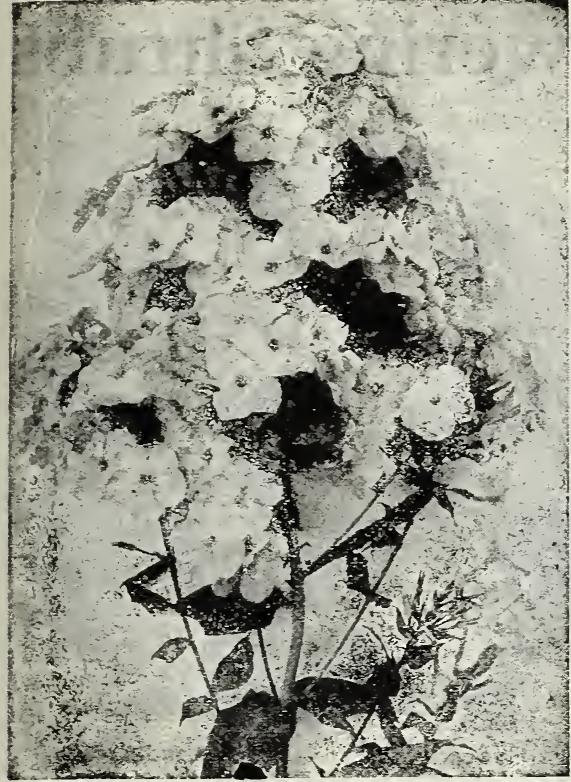

Hardy Phlox

\section{Archias' Superb Peonies}

THE MOST POPULAR OF ALL HARDY PERENNLALS. THE ROYAT FLOWER OF CHINA

Festiva Maxima-Pure white with carmine spots on center petFlowers of immense size, long, stiff stems. Each, 40c. Queen Victoria or Whitleyi-Large, full white, with creamy Queen 30 each.

Fioral Treasure (Rosenfield)-Mid-season to late, bright light pink bud of good form and will undoubtedly prove to be a valuable flower variety. 35c.

Rubra Superba (Richardson)-Very late, rich brilliant crimson ding to violet, very large and double 40c. Charlemagne (Crousse 1880 ) -Color delicate tint of wac or hel-
lotrope; late bloomer. Each, 40c.

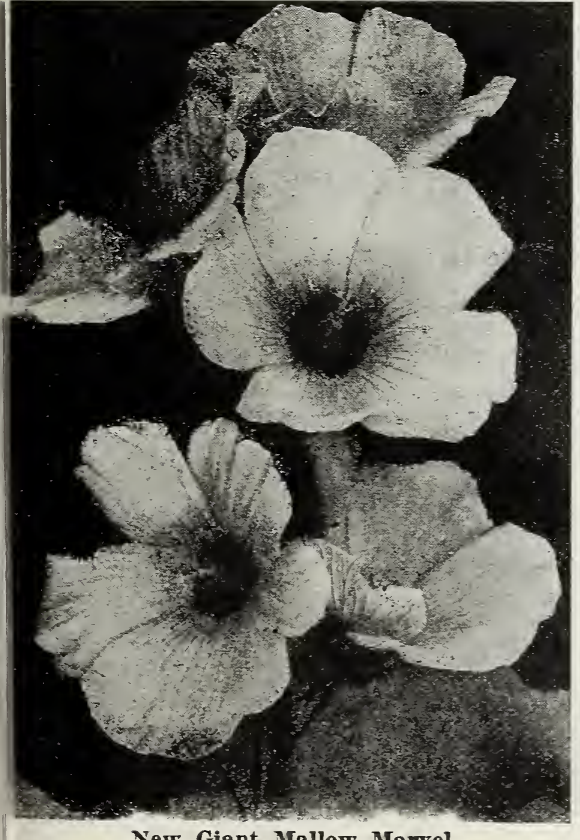

New Giant Mallow Marvel

Edulis Superba-Beautiful rose pink, very early, fragrant. Each, 35c

Mons. Jules Elie (Crousse)-Immense, globular silvery pin flower: by many, claimed to be king of the pink varieties of peonies, Each, i5e.

Mons. Dupont (Calot)-Large, fine, cup-shaped bloom, ivory white with carmine markings; extra fine, mid-season to late. Fach, 50c.

Mons. Crousse-Mid-season, deep, dark rich red, known as American Beauty on the cut-flower market. Each, 45c.

Golden Harrest (Rosenfield)-Mid-season, blush guard, yellow, cream and carmine markings; a fine flower. You cannot afford to leave this out of your collection. Each, 45c.

SPECIAL OFFER-One each of the ten superb named Peonies for only $\$ 4.00$, or 5 for $\$ 2.15$, postpaid.

Unnamed Peonies-In white, pink and crimson shades, all double rarieties, as follows: Each, $25 \mathrm{c} ; 6$ for $\$ 1.25$; doz., $\$ 2.25$. post paid.

\section{New Giant Mallow Marvels}

These Mallows are considered as the most marvelous of al hardy plants. Their flowers are of enormous size, often measuring 8 to 10 inches across, and are gorgeous in color. They bloom in the greatest profusion from July to October, and when in flower are a sight to behold. The plants are as hardy fail to include some of these in your order.

Red Marvels-Shades of red. Each, 35c, 3 for $\$ 1.00$; doz., $\$ 3.00$

Mixed-Each, 25c, 5 for $\$ 1.00$, doz., $\$ 2.00$.

\section{Hedge Plants}

Berberis Vulgaris Pupurea (Purple Barberry)-Violet colored foliage and fruit. strong 15 to 18 -incl plants: 10 for $\$ 1.25 ; 25$ for $\$ 2,50 ; 100$ for $\$ 10.00$.

Berberis Thunbergii-Small foliage, assuming the most varied and beautirul tints of coloring in the autumn, strong 15 to 18 -inch plants; 10 for $\$ 1.50$; 25 for $\$ 2.50$; 100 for $\$ 10.00$. 


\section{ARCHIAS' Hardy Flowering Shrubs \\ Shrub orders must reach us not later than April 15th, as the plants will not usually remain dormant af-} ter that date and they cannot be successfully handled except in a dormant condition.

\section{Rose of Sharon, Althea}

(Flowering Hedge Shrub).

A strong, erect-growing shrub of the easiest culture and unsurpassed by anything in the hardy shrub line for freedom of bloom or range of color.

Double Red, Double Purple, Double White. 25c each; 5 for $\$ 1.00$, postpaid. Large 2 -year-old plants, $35 \mathrm{c}$ each; 3 for $90 \mathrm{c}$.

\section{Deutzia}

A showy class of shrubs of compact growth, luxuriant foliage and very free flowering. Price, either of the following, $25 \mathrm{c}$ each; 5 for $\$ 1.00 ; 12$ for $\$ 1.75$.

Crenata-4 to 6 feet; flowers white, tinged rose; very double and full.

Gracilis -2 to $2 \frac{1}{2}$ feet; drooping; snowy white flowers.

Pride of Rochester-Flowers are pure white, with a faint shade of blush on outside of petals.

\section{Golden Leaf Elder}

Is the most showy of all shrubs for the lawn. Height about 6 feet, has wide spreading branches. Its leaves are of dark, dazzling yellow color. Large plants, each, $35 \mathrm{c} ; 3$ for $\$ 1.00$.

\section{The Sweet-Scented Shrub}

(Calycanthus Floridus)

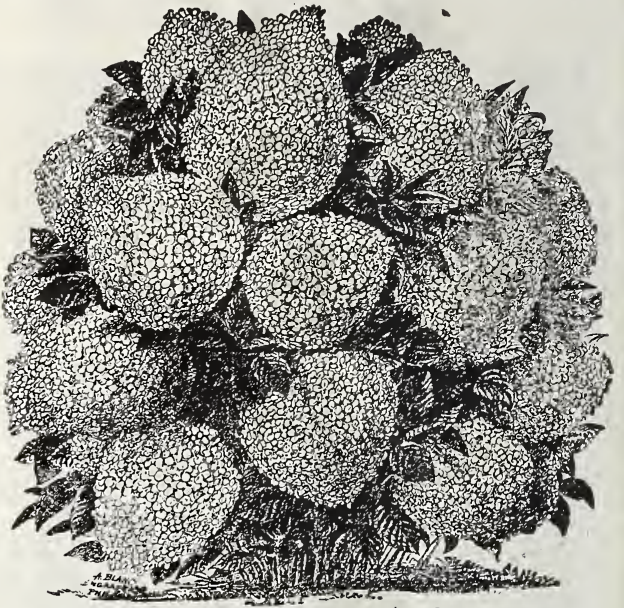

Hydrangea Paniculata Grändiflora

An old favorite and well known shrub for its strawberry

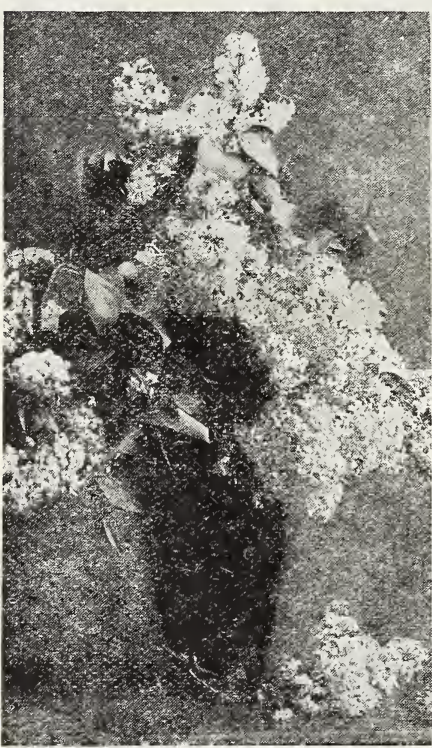

Persian Lllac scented flowers. The flower ver 3 for $\$ 1.00$.

\section{Hydrangea}

Paniculata Grandiflora-Hardy shrub from Japan. Flowers pure white, changing to pink; blooms 3 months in summer; height, 3 to 4 feet. Price, large plants, 25c each; 3 for $60 \mathrm{c}$. Extra large plants, 35c; 3 for $\$ 1.00$.

American "Everblooming" Hydrangea-A new addition from western Pennsylvania. Perfectly hardy, bearing pure white flowers of immense size from June to September. Include this in your order. Large 2-year-old plants, $40 \mathrm{c}$ each; 3 for $\$ 1.00$, postpaid.

\section{Persian Tree Lilac}

Popular Favorite for Their Beauty and Perfume.

A neat, handsome growing little tree growing seven to eight feet high, with slender branches and long, narrow foliage. The flowers grow in immense clusters delightfully and deliciously sweet and fragrant. We offer nice, strong plants.

Persian Blue-35c each; 3 for $\$ 1.00$, postpaid.

Persian White $-35 \mathrm{c}$ each; 3 for $\$ 1.00$, postpaid.

\section{Snowball}

Viburnum-Growth upright and compact; 6 to 8 feet high. Foliage olive green.

Japanese Snowball (Viburnum Plicatum)-A large and quick-growing shrub. Flowers are immense and very double; purest white; very showy. Each, large plants, 35c; doz., $\$ 3.50$.

\section{Spireas}

Prunifolia-Well-known and popular variety. Blooms in May, with pure white double flowers. Makes showy specimen plants for lawns.

Van Houttei (also called Briday Wreath)-One of the most beautiful. An immense bloomer. Flowers pure white and borne in elegant plumeshaped clusters.

Anthony Watherer-The pink spirea. Forms a round, compact bush 18 inches high. Begins to bloom early and continues until fall.

Price of above spireas, each, large plants, 25c; 5 for $\$ 1.00$.

\section{Syringa}

Mock Orange-Each, large piants, 25c; 5 for $\$ 1.00$.

\section{Weigelia}

Handsome flowering shrubs, with trumpet shaped flowers, borne in clusters.

Candida-Pure white. A very fine sort.

Eva Rathke-A new variety; rich, purplish red bloom; entirely distinct from others; free bloomer the whole season. pink

Rosea-Flowers very profusely, in various shades of rose and

Above, each, large plants, 25c; doz., $\$ 2.50$.

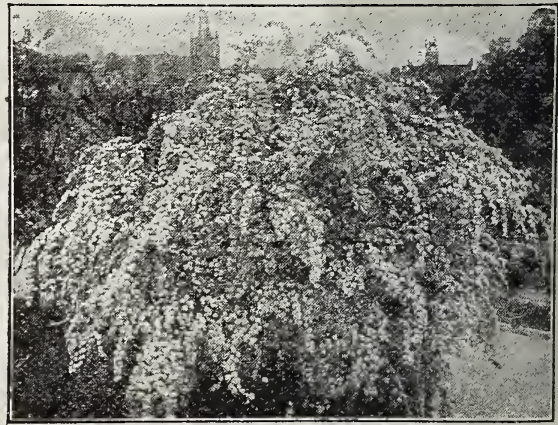

Spirea- "Bridal Wreath" 


\section{Archias' Hardy Ornamental Climbing Vines}

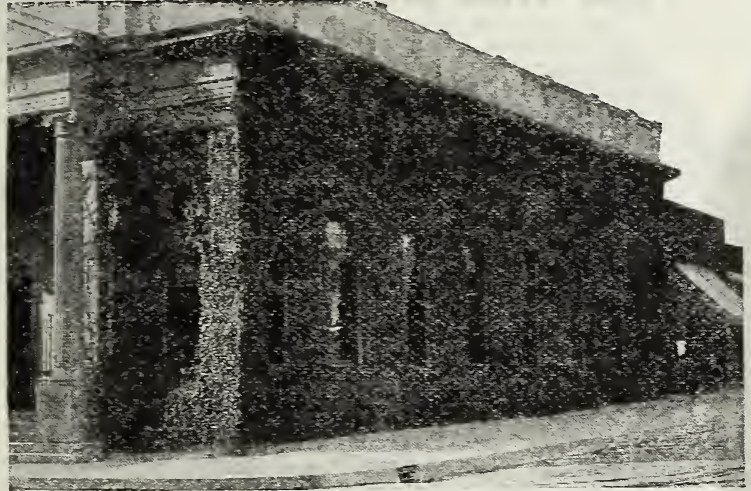

Ampelopsis Veitchi (Japan or Boston Ivy)

\section{Clematis}

Price of Clematis, 3-year-old strong plants, $40 \mathrm{c}$ each; 3 -for

Clematis Paniculata (Japanese Virgin Bower)-One of the finest climbers; clouds of small, fragrant flower:s; blooms in August and September. The most elegant sight and pleases all.

Henryii-A vigorous grower and a free bloomer, producing its large, pure white flowers constantly during summer and early autumn. The best large flowered white variety.

Jackmanii-The flowers are large, intense,

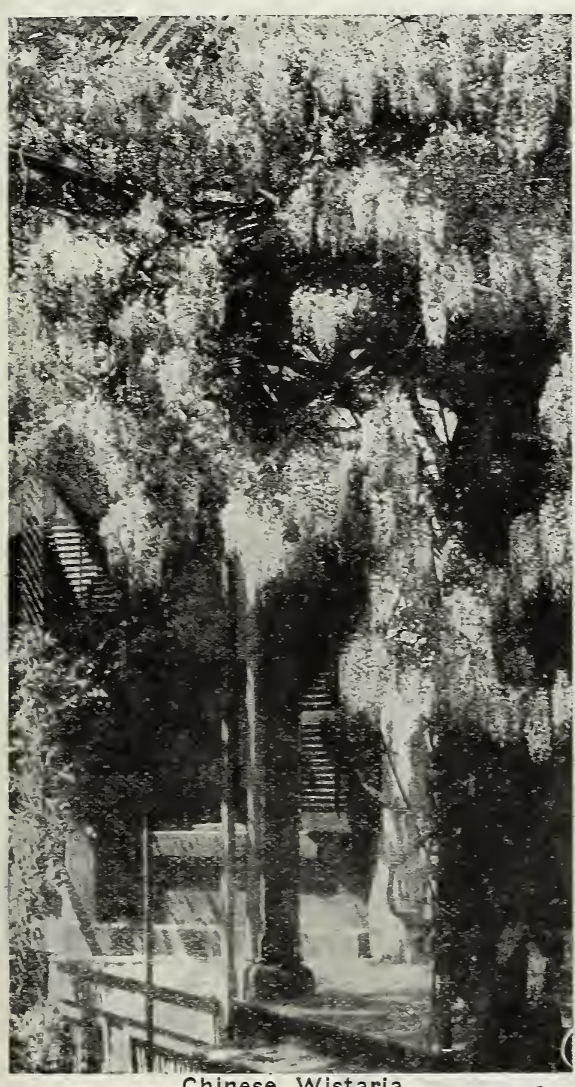

\section{Archias' Ampelopsis}

Ampelopsis Veitchl (Japan or Boston Ivy) - A rapid grower, with small purplish green leaves, son and orange.

Ampelopsis Quinquefolia (Virginia Creeper)-A ell-known hardy native climber.

Two-year strong, 25c each; 5 for $\$ 1.00 ; 12$ for $\$ 2.25$.

\section{Aristolochia Sipho}

(Dutchman's Pipe)-Large, showy, light green foliage; flowers long and pipe-shaped; makes a dense screen. Price, 50c each; $\$ 5.00$ per dozen.

\section{Chinese Matrimony Vine}

(Lycium Chinese)-Bright purple flowers, suc(Leded by brilliant scarlet berries. Large 2-year plants, each, 25c; 5 for $\$ 1.00 ; 12$ for $\$ 2.00$, postpald.
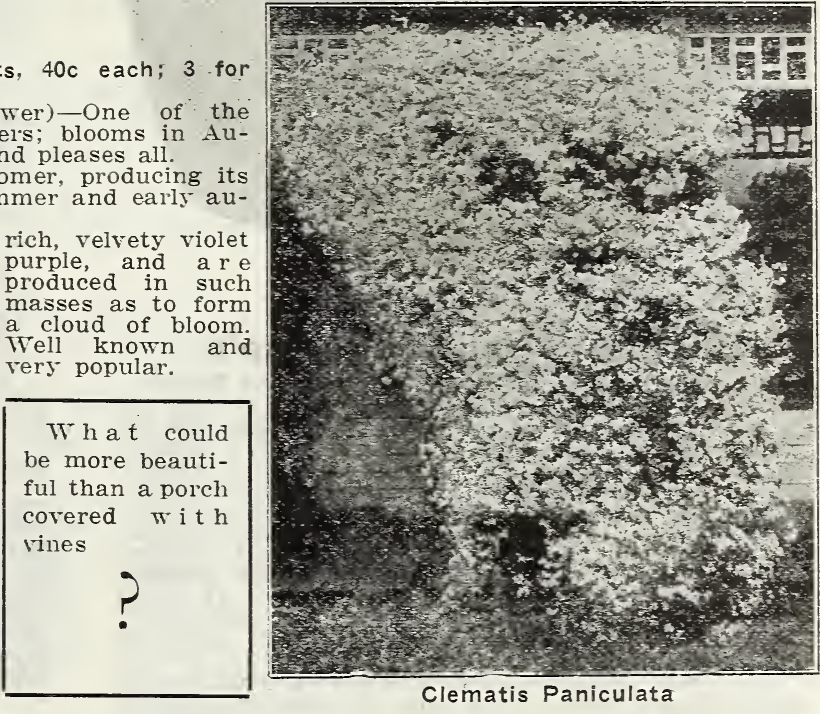

\section{Honeysuckles}

Hall's Japan or Hallena-White and creamy yellow; fiagrant; bloom the whole season. Almost evergreen.

Monthly Fragrant-Red and yellow; very fragrant. Bloom a!l summer.

Scarlet Trumpet-Red flowers; bloom freely; rapid grower.

\section{Hardy English Ivy}

This is a hardy evergreen climbing vine, for covering the walls of churches and for covering graves, especially where grass will not succeed well. Each, 12c; 3 for 30c; 12 for $\$ 1.00$, postpaid.

\section{Chinese Wistaria}

Two-year plants, each, $35 \mathrm{c} ; 3$ for $\$ 1.00$, postpaid.

Chinese Purple-Rich, riolet purple color, deliciously scented and handsome.

Chinese White-Similal habit to the purple variety

\section{Hardy Sweet Peas}

Rosy red and pure white. Blooms profusely all summer. Each, 20c; 2 for $35 c$; dozen for $\$ 1.50$, postpaid. For other Hardy Vines. see pages 46 and 60.
$\$ 1.00$ postpaid 


\section{Archias'Selected Fruit Trees, Grape Vines\& Plants}

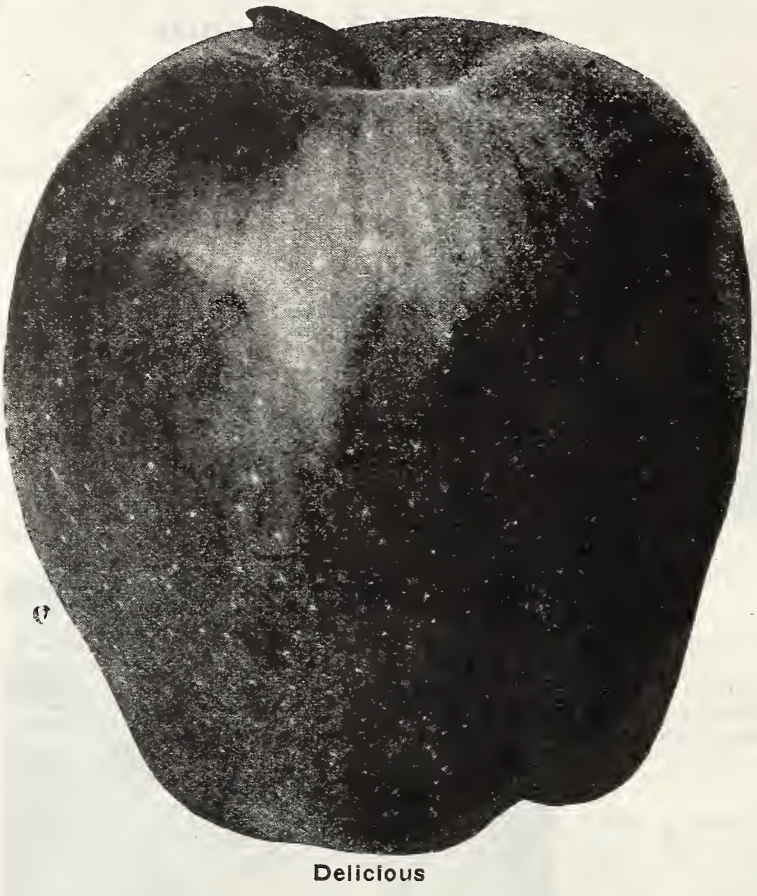

Archias' "Delicious" Apple

The Most Wonderful Apple in Existence Today Delicious is always remembered by the customer for its luscious flavor, its delightful crispiness and its unique shape, conical, tapering, with five distinct knobs at the blossom end. The flesh is fine, tender, firm and overflowing with rich, highly flavored juice. Its fragrant aroma will perfume a whole room.

The skin is thin, but tough. It stands handling: without injury. Delicious is the greatest moneymaker of all. It is the apple the best fruit growers recommend to their particular customers. The tree is hardy, vigorous grower, bears fourth to sixth year. Grown commercially wherever apples will grow. A greater range than any other variety.

Its vigor, productiveness, hardiness and the exceptionally high quality of the fruit, its great beauty and unusual shipping qualities put Delicious in a class by itself.

Price of Archias' Delicious 2-year extra strong trees, each, $45 \mathrm{c} ; 3$ for $\$ 1.25 ; 6$ for $\$ 2.00 ; 12$ for $\$ 3.50$.

\section{The World's Best Peach Archias' Missouri Pride}

Resembles Elberta in color and flavor, but tree is hardier: a strong grower and productive. Bears when Elberta fails.

Averages one-third to one-half larger than Elberta. Round, uniform shape.

Color-Rich, golden yellow, overlaid with carmine. olors up ten days before maturity.

Flesh-Solid and meaty. Texture of a cling, yet perfect freestone. Without grain or stringiness. Smooth, thick skin, tightly drawn.

Most delicious flavor, seldom found in a yellow peach. Far surpasses Elberta.

Shipping-So firm it ships almost like apples. Unusually long keeper.

Price of Archias' Missouri Pride, 3-year-old extra choice trees, each $45 \mathrm{c} ; 3$ for $\$ 1.25 ; 6$ for $\$ 2.00$; 12 for $\$ 3.50$. Order early.
Our Trees are Free From Disease

All stock is thoroughly inspected by the State Entomologist each fall just before digging time. Every precaution possible is taken for the protection of the customer and his stock, and each box or bale is tagged with the State Entomologist s Certificate of Health Inspection.

Thirty-two page Nursery Guide, with full description and instructions for planting, cultivating, spraying, etc., sent free with an order. Ask for it.

Ready for shipment about April 1st. Send your orders early and due notice will be given of shipment. No charge for packing. Only finest trees and plants shipped. Do not buy cheap, worthless trees from tree agents.

\section{Archias' Apple Trees}

Two years, 5 to 6 feet, well branched. Each, 35c; 4 for $\$ 1.20 ; 12$ for $3.00 ; 25$ for $\$ 5.50$.

\section{Summer Varieties}

Yellow Transparent-Very early; light yellow: medium size; juicy. sub-acid.

Red June-Choice quality; very early; dark red; medium size.

Early Harvest-Large, golden yellow; splendid quality. Very popular in lowa for many years.

\section{Autumn Varieties}

Maiden's Blush-Yellow, with beautiful blush cheek. Good quality; medium large.

Rambo-Medium; striped yellow and red. Quality extra choice.

Ramsdell Sweet-Large; rather oblong shape; dark red. Best fall sweet apple.

\section{Winter Varieties}

Banana-Large golden yellow, blush cheek. Of splendid quality. Popular with western orchardists.

Ben Davis-Large, red, striped yellow, good quality, good keeper. Profitable market sort

Black Ben Davls-Improved Ben Davis. Very pretty.

Grimes; Golden-Iarge, golden yellow. Favorite sort because of extra choice quality.

Genetin (Rawle's Janet) - Small to medium; red and yellow striped. Very productive; long keeper.

Jonathan-Most popular of all. Large, deep red. Rich inflavor, juicy and sweet.

Wealthy-Large, red, showy, sub-acid and productive. Most popular of all.

Stayman's Winesap-Medium. Deep red. Quality ery fine.

Wolf River-Largest of all; grow to weigh 4 pounds. Yellow, striped light red. Productive.

Gano-An improved Ben Davis; nearly covered with deep dark red.

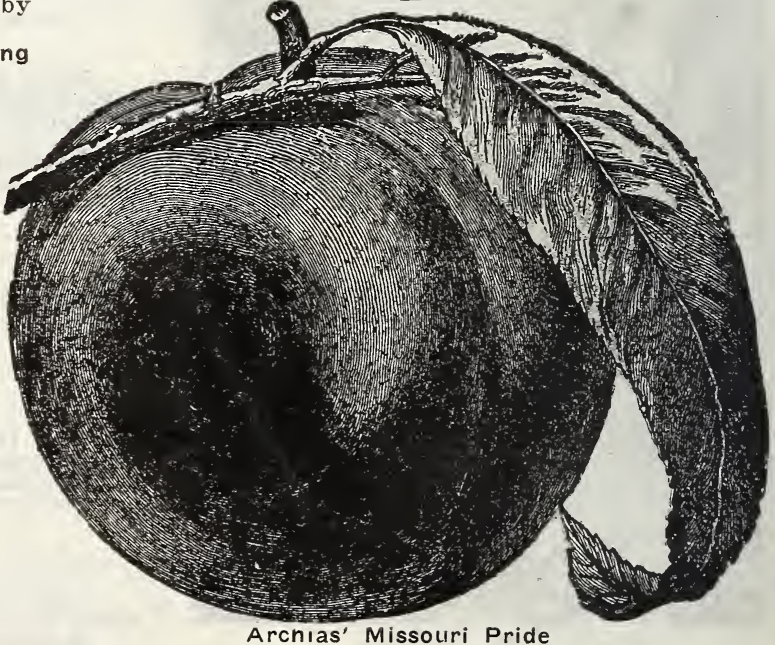


A R C I A S ' SEED STORE, SEDALIA, MISSOURI

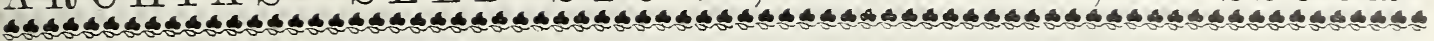

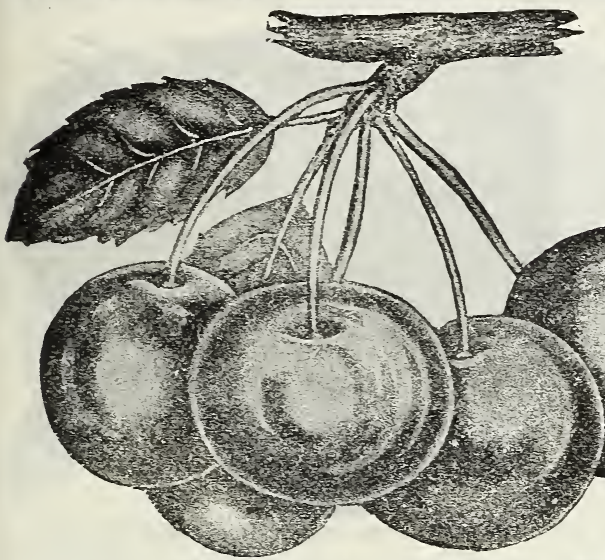

\section{Cherries}

Select 2-year; 4 to 5 feet; branched. Each, $45 \mathrm{c} ; 3$ for $\$ 1.25$; doz., $\$ 4.00$.

Early Richmond-Nedium size, dark red, juicy, acid flavor. Unsurpassed for cooking. The standard early variety in the Middle West.

Montmorency-Large, red, acid Cherry; is larger than Early Richmond and about ten days later. A superior sort for home use. Wragg-Large, late, acid variety; dark purple; very productive.

\section{Enctis}

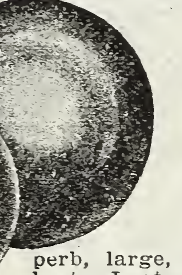

perb, large, yellow peach. One of the Crosby-

Crosby-One of the hardiest; abundant bearer; medium size, bright yellow, Champion-A large, handsome, early variety, wheek; sweet, rich and juicy. Hardy and productive. August. Free. Chinese Cling-Large, white shaded red; fine quality. A favorite variety in the South. August.

Elberta-Large; yellow, with red cheek; flesh yellow, firm, juicy. Exceedingly prolific; sure bearer and hardy. The leading market variety. Follows Crawford. Free.

Heath Cling-Very large; flesh white, juicy and melting. Good keeper and shipper. October.

\section{Pears}

Standard, 5 feet and up. Each, 45c; 3 for \$1.25; doz., \$4.00.

Kieffer-Large, rich color and good quality. Excellent for canning; will keep until winter. Hardy. Ripens in October. in August.

Seckel-Small, but of excellent quality; rery hardy. Ripens in September

Flemish Beauty-Large, juicy, rich; one of the hardiest and most popular. September and October.

\section{Plums}

Select 2-year, 5 to 6 feet. Each, $45 \mathrm{c}$; 3 for \$1.25; doz., \$4.00. Burbank-Considered by some to be the best of all the European
sorts. Color clear cherry, with thin lilac bloom. Flesh deep yellow; very sweet and agreeable.

Wild Goose-Large, rich and melting; delicious. Strong grower and prolific.

Shropshire Damson-Medium: dark purple; very productive; best for preserving. October.

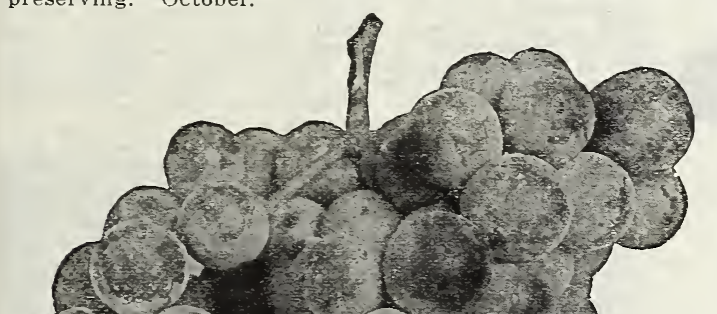

Yellow Egg-Very large, egg-shaped, productive. lent for cooking. August. FREIGHT PAID on fruit trees and nursery steck only when order amounts to $\$ 10.00$ or over.

Eight Grand Prolific Hardy Grapes for \$1.25 Prepaid Strong 2-year vines of any variety. 20c each; 3 for $55 \mathrm{c}$; or set of 8 for $\$ 1.25$; 25 for $\$ 3.00 ; 100$ for $\$ 10.00$. prepaid.

prepaid. Brighton-Dark red, bunches large; berry medium size;
skin thin; flesh tender; quality the best. Almost seedless.

Campbell's Early--Strong, vigorous vine; bears abundant clusters large, handsome black grapes of a delicious

Arehias' IIammoth Concord-An improved early hardy variety of the good old Concord. Very prolific, and in all a most val-

Ives Seeding-Bunches large, long, of fine quality and very hardy. A good table and wine grape. Exceedingly prolific.

Moore's Early-This is the finest early black grape known. The fruit is very large and of a delicious flavor; extremely hardy. Moore's Diamond-A grand white grape; prolific, tender and excellent quality.

Niagara-Leading white grape of the day; large bunches, delicious flavor; exceedingly productive; hardy.

Worden-Black; handsome, compact bunches; ripens earlier than Concord.

\section{Raspberries}

Prices, except where noted: Doz., 60c; 25 for 75c; 100 for $\$ 2.50$.

Columbian-A large, purple sort; unexcelled for productiveness. Fine quality.

Cuthbert-A red sort and the standard for market; large, handsome; very sweet.

Cumberland-The largest of all blackberries. rood shipper and market variety.

Haymaker-An enormous producer; fruit a little more acid and is later than the Columbian; one of the most productive purple Raspberries.

Miller-Large, round, brilliant red; prolific and hardy; early.

Do not class Archias' fruit trees with the cheap, worthless stock sold by some nurseries.

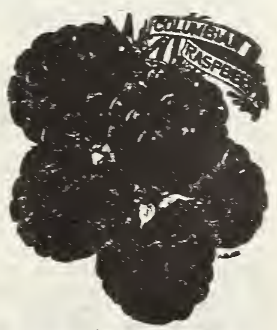

Columbian Raspberry 
GROW '"S U R E SEED S,' PLA N T A N D TREE S stsksfists

\section{The Everbearing Raspberry--ST. REGIS It Bears The First Season}

One of the greatest raspberries ever introduced. Plants of the ST. REGIS put out in the fall or early April gave ripe berries on the 20 th of June and the canes continued to produce ripe fruit without intermission

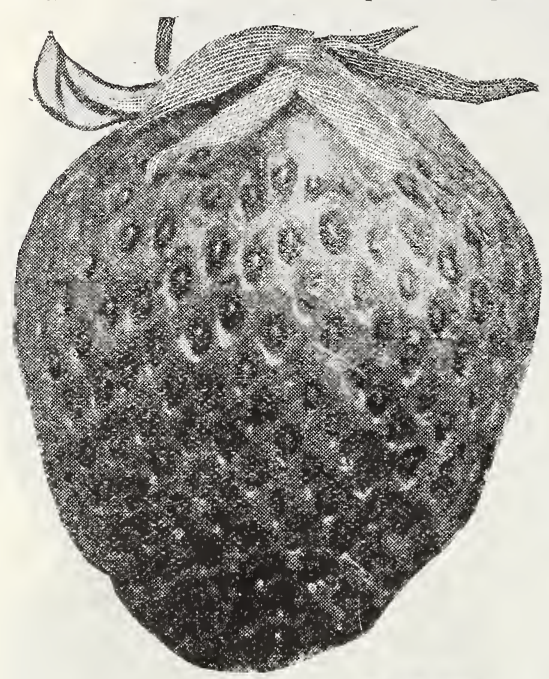
until late October. The berries were large and beautiful, firm and ful flavored, to the very is the only raspberry, as far as known, that is practically sure to produce a crop of fruit th $\theta$ season planted. certificate of merit by the AMERICAN INSTITUTE OF NEW YORK. plants: each, 15c; 12 plants: each, 15c; 12 100 for $\$ 6.00$, prepaid

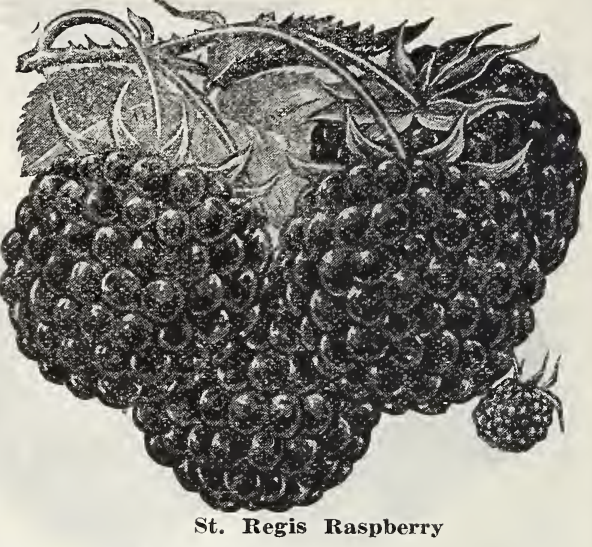

\section{Strawberries}

Plant 16 inches apart in rows, $3 \frac{1}{2}$ feet apart, requiring 9,000 plants er acre. Deep, loamy, sandy soil, with clay sub-soil, is preferable.

Those marked (P) are pistellate varieties. They are the most productive, but a row of (S), a staminate or perfectly formed, sort, should be planted every 10 or 12 feet, to pollenize the flowers.

\section{Six of The Best Ones}

Clyde (S)_Large and showy; early.

Crescent $(P)$ - Early; bears profusely.

Bubuch (P)-Midseason. Indispensable on account of its large, bright Glenmense yield and fine flavor.

Glen Mary (P) - This fine variety is of large size, good quality and large yield; one of the best. Color dark, glossy crimson. Fruits bountifully conditions.

Senator Dunlap (S) - Large, attractive fruit. Medium early. Plants vigorous growth.

Gandy (S) - Large, bright red berries. Very late Extensively planted or market purposes.

Price, 25, 25c; 100, 75c; 200, $\$ 1.35 ; 500, \$ 3.00 ; 1,000$. \$5.75. By mail add $10 \mathrm{c}$ per 100 postage.

\section{Archias' Everbearing Strawberries}

\section{ARCHIAS' PROGRESSIVE}

We recommend the Progressive as the best of all fall-bearing varieties to date. The originator of the Progressive, Mr. Harlow Rockhill, of Iowa, considers Progressive the best of the fall-bearers, and better than a great many spring-bearing varieties. With us, the Progressive is a good grower, resembling Dunlap in habit of growth, and a heavy bearer. The blossoms must be kept pinched off until midsummer. until the plants have a chance to make midsummer, ners and plants for the fruiting beds. This must be done at least onch a week, as theds. This must be done at least onch a week, as the plants are so persistent in producing blossoms that if left over a week picked over one hundred with young fruit. We have picked over one hundred and fifty blossoms and green berries from one plant, and it is no uncommon thing to see blossoms or even ripe berries, on the runner plants which have not yet rooted. The berries are simply delicious in quality, and the fact that they come when other Strawberries have gone makes the quality seem even better. The berries part readily from the cap, and if kept picked closely are firm enough for distant, shipment.

Price of Archias' Progressive Everbearing Strawberries: 12 for $40 \mathrm{c} ; 25$ for $65 \mathrm{c} ; 50$ for $\$ 1.00 ; 100$ for $\$ 1.75$,

Archias' Progressive postpaid.

\section{Archias' Everbearing Strawberries- "Superb"}

You can have strawberries just as easily in the fall as in the spring by planting the Supp Strawherries. These varieties will produce heavy crops in the fall, of as fine berries as any spring-ripening strawberries. Truly a luxury for home, and profitable for marlet. Think of having all the berries you can use on your table during
the months of September, October and November, and later, if not killed by freez-

the months
ing weather.

If you grow them to sell you can get your own price for strawberries at that season of the year, and there is no strawberry known that is so prolific as "Superb." They commence blooming early in the spring, and the blooms should be kept removed until about the middle of August. By doing this you get a larger yield in the fall than you would if allowed to bear all summer. So prolific are they that the young plants that are formed in the summer will bear in the fall of the same year; in fact, the young plants will very often send up fruit stems before they become rooted. They are not a novelty nor an experiment, but are a success, and you can have strawberries as well in the fall as in the spring-strawberries of good quality for your table every day during the late summer and fall; strawberries for Thanksgiving. Remember, we are living in an age of rapid advancem

Price of "Superb" Everbearing Strawberries: 12 for $40 \mathrm{c}$; 25 for 65c to for $\$ 1.00 ; 100$ for $\$ 1.75$, postpaid.
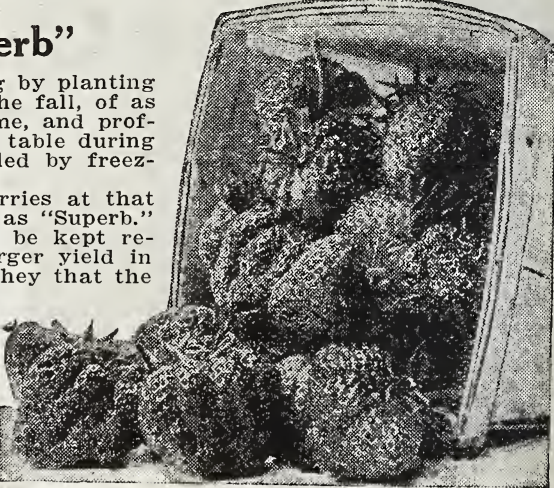


\section{A R C I A S , SEED STORE, SEDALIA, MISSOURI}

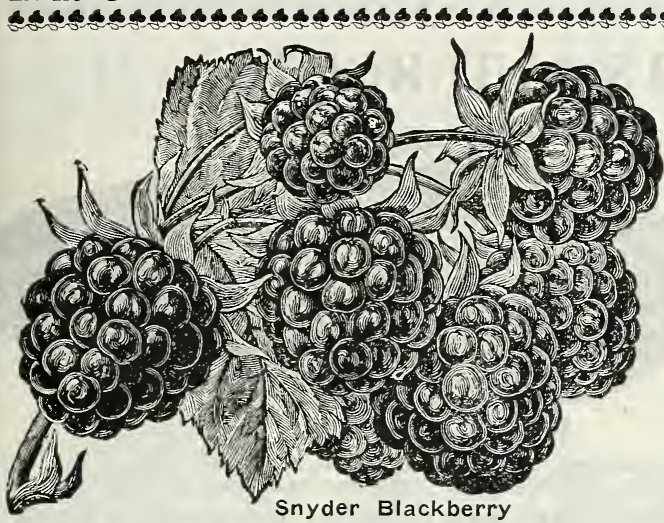

\section{Giant Himalaya Blackberry}

A grand new berry, extremely hardy; of large size; for $\$ 1.00 ; 12$ for $\$ 1.75$, postpaid.

\section{Blackberries of Merit}

From Root Cuttings, each, 10c; 10 for 50c; $100, \$ 3.50$. Ancient Briton-One of the best known berries; large and sweet. Hardy, medium size and best quality.

Stone's Hardy-Extremely vigorous and hardy. Fruit juicy, sweet, of fine flavor and good quality.

Snyder-The canes are vigorous and exceedingly productive. Berries medium, sweet, juicy and of fine flavor.

Early Harvest-One of the earliest; berry medium sized, good quality and very prolific; firm and attractive appearance. A good market sort.

\section{GOOSEBERRIES}

Downing-Largest of our native Gooseberries; pale green; very sweet; 2-year-old, each, $25 \mathrm{c}$, postpaid; not postpaid, dozen, $\$ 1.75 ; 25$ for $\$ 3.00 ; 100$ for $\$ 10.50$.

\section{Price same as Downing.}

Houghton-Well known; medium size; pale red; very productive;

Industry-Vigorous growth; free from mildew or other diseases; large, handsome, fruit of delicious quality. Berries dark in color, rich and sugary; 2 years old. Each, 35c; 3 for $\$ 1.00$; or $\$ 2.50$ per dozen, postpaid.

\section{Currants}

Fay's Prolific-The leading red market variety.

White Grape-Very productive; excellent quality. paid.

Two-year-old, each, 25c; 3 for $50 \mathrm{c}$; doz., $\$ 1.75$; per $100, \$ 8.00$, prewith with rich sub-acid flavor, plenty of pulp and few seeds. Best currant lately introduced. Won the gold medal of the Western New York Horticultural Society competition with all the old leading varieties; also gold medal at St. Louis World's Fair. Each, $35 \mathrm{c}$; 3 for $\$ 1.00$; doz., $\$ 3.00$.

\section{Evergreen Trees by Parcel Post}

12 Different Kinds. Put up in Packages of 50 Trees. Each Package, $\$ 1.00$; any Six for $\$ 5.00$, Prepaid.

Fine for Hedges, Windbreaks and Ornamental Lawn Planting. Safe Arrival Guaranteed to Any Point in the United States.

\section{Complete Planting Instructions and Cultural Directions Will Be Furnished With Each} Order.

Evergreen trees will bring a new beauty and charm to your home. There is unquestionably no better. way of beautifying your place than surrounding it with beautiful Evergreens. As an ornamental tree Evergreens are unsurpassed. Plant some Evergreens around your garden and just see how much difference there is in the temperature and moisture. You will find that you can grow flowers, fruits and vegetables that you never could before.

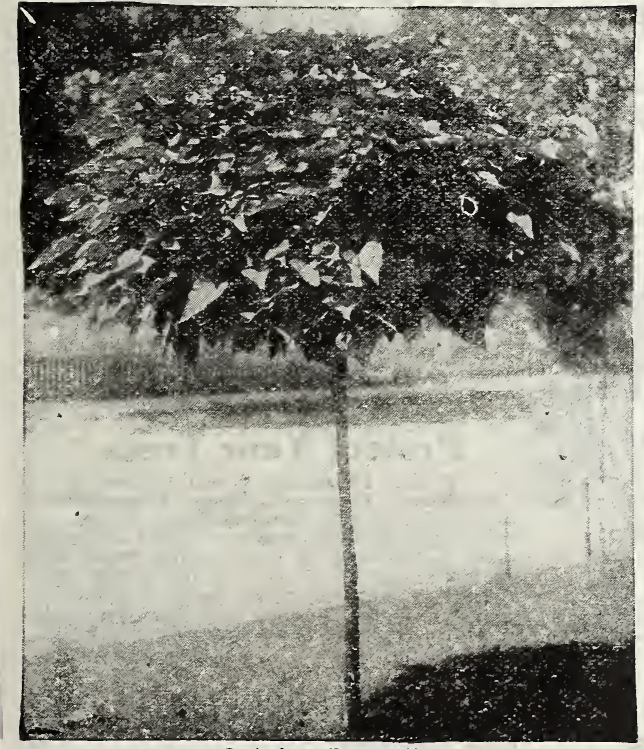

Catalpa Bungeii
These varieties have been thoroughly tested and proven absolutese varieties have been thoroughly tested and proven all parts of the

during March, April or May, depending on locality.

2.-50 Scotch Pine, Tall Bluish Green-2-5 2-year seedings.

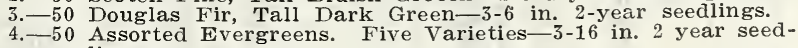

5.-50 Colorado Blue Spruce, Tall Silvery Green-3-6 in. 3-year seedlings.

6.--50 White Pine, Tall Lustrous Green-3-6 in. 2-year seedlings. 7.-Black Hill Spruce, Tall Bluish Green-3-6 in. 3-year seed(lings.

8. - 50 American Arbor Vitae, Conical Deep Green-4-8 in. 3-year seedlings.

9.-10 Assorted Evergreens, Large-Size-Transplanted 4 years old. 10.-50 Jack Pine, Tall Bright Green-3-6 inch 2-year seedlings. 11. -50 Red Cedar. Medium Bright Green-3-5 in. 1-yr. seedlings. 12. - 50 Ponderosa Pine, Tall Dark Green-3-6 in. 2-year seedlings.

Price, postpaid, $\$ 1.00$ per package; any 6 for $\$ 5.00$. You can not afford to overlook these offers. THINK OF IT-50 TREES FOR $\$ 1.00$.

\section{ORNAMENTAL TREES}

We can supply the following ornamental trees at prices named. Customers will please note that these can be shipped with fruit trees or plants, if so desired, as they are shipped direct from the growing station. Purchaser to pay all freight or express charges.

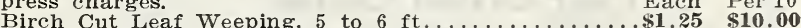

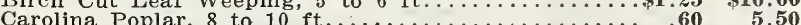

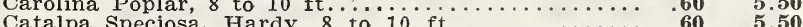
Catalpa Bungeii, 6 to 8 ft.......................6.5. $\mathbf{1 2 . 0 0}$ Catalpa Bungeii, 6 to 8 ft................ Catgalpa Bungeii, Extra select..... Elm, American White, 8 to $10 \mathrm{ft}$ Mountain Ash, 8 to $10 \mathrm{ft}$ Tulip Tree, 6 to $8 \mathrm{ft}$. . Tulip Trees, Extra Select, each Teas' Weeping Mulberry, 1-year... $\$ 2.00$ to 2.50

$1.00 \quad 8.00$

$.75 \quad 6.00$
$1.00 \quad 8.00$

$75 \quad 600$ $\$ 1.25$ to 1.50

6.00 
GROW "S URE SEEDS," PLA N T A N D T RES

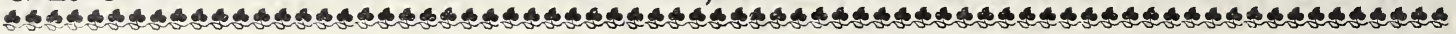

\section{VEGETABLE PLANTS AND ROOTS}

All orders must be accompanied by CASH to insure prompt attention. No plants sent C. O. D. Vegetable

\section{Sage Plants}

IIolt's Mammoth-The largest variety grown; plants are strong. Each, 15c; 2 for $25 \mathrm{c}$; 5 for $55 \mathrm{c}$; doz., $\$ 1.25$, postpaid.

Tomato Plants-Transplanted. Price, doz., 20c; 50 for 50c; 100 for $95 \mathrm{c} ; 1,000$ for $\$ 7.50$, post paid.

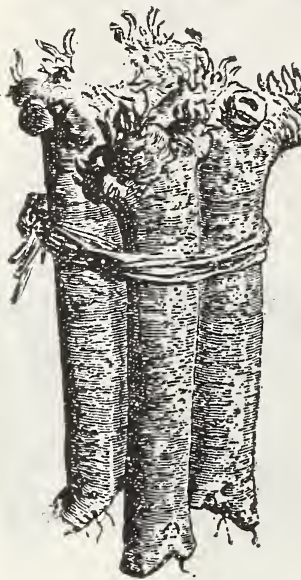

Pot-grown Tomato PlantsExtra strong, with ball of 100 for $\$ 2.50$.

Cabbage Plants-Transplanted. Doz., 25c; 50 for 50c; 100 for $95 \mathrm{c} ; 1,000$ for $\$ 7.50$, postCabbage Plants-Not transplanted. 60c per $100 ; \$ 5.50$ per 1,000 , postpaid.

Cauliflower Plants-Snowball and Extra Early Erfurt, 25c doz.; 25 for $45 \mathrm{c}$; 50 for $75 \mathrm{c}$; 100 for $\$ 1.45$, postpaid.

Sweet Potato Plants-100 for $50 \mathrm{c} ; 500$ for $\$ 2.25 ; 1,000$ for $\$ 1.25$, postpaid.

Celery Plants-Field grown and transplanted. 100 for $\mathbf{7 5 c}$; $\mathbf{1 , 0 0 0}$ for $\$ 6.00$, postpaid.

Pepper Plants-Doz, 25c; 50 for $75 \mathrm{c} ; 100$ for $\$ 1.25$, postpaid. Horseradish Sets-25 for 25c; 100 for $75 \mathrm{c} ; 1,000$ for $\$ 6.00$, postpaid.

Rhubarb Roots - Mammoth Victoria - Large roots, $10 \mathrm{c}$ 100 for $\$ 4.50$, not prepaid.

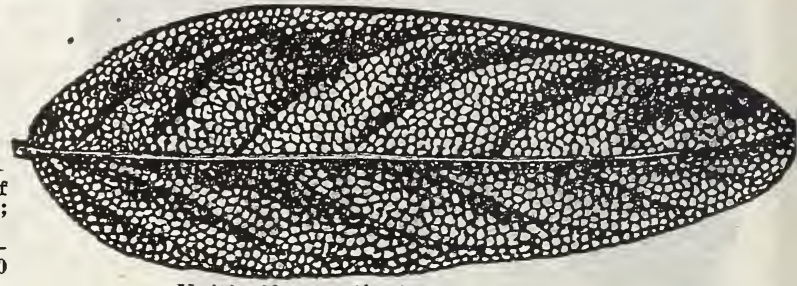

Holt's Mummoth sage

Asparagus Roots-Colossal, best 2-year. Doz., 20c; 25 for $40 \mathrm{c}$; 100 for $\$ 1.25 ; 1,000$ for $\$ 9.00$, not prenaid.

Potato Plants are in season only from April 1st to July 1st.

Egr Plant-New York Improved Purple. Doz., 40c; 25 for $75 \mathrm{c} ; 100$ for $\$ 2.00$, prepaid.

Parsley Plants-Doz., 30c; 25 for 50c; 100 for $\$ 1.50$, prepaid.

Chives-Small plants of the onion family, used for seasoning. Clumps, each, 15e; 2 for 25c; 5 for $50 c$, postpaid.

The prices of Vegetable Plants are for the earliest plants; later in the season prices are lower.

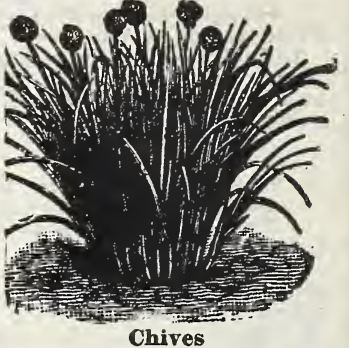

Chives

\section{GARDENERS' AND FLORISTS' SUNDRIES}

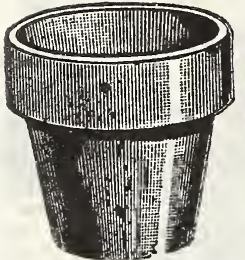

Flower Pots

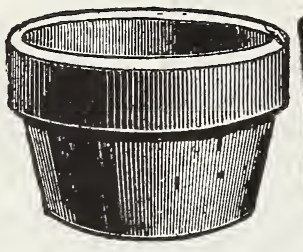

\section{Pots and Saucers}

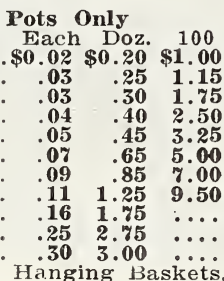

\section{Fruit Packages}

BERRY BOXES AND CRATES

This is the old standby style of market packing and is great favorite. A very neat and strong package. Boxes hold full measure quarts.

Boxes in flat, $\$ 1.60$ per $500 ; \$ 3.00$ per 1,000 ; in lots of 10,000 at $\$ 2.90$ per 1,000 .

4-Quart Crates-10c each; 10 for $90 \mathrm{c} ; 100$ for $\$ 8.50$.

American Style Square 1-qt. Berry Boxes, 65c per 100; $\$ 4.50$ per 1,000 .

American Style Crates, 20c each; $\$ 18.00$ per 100

Tacks-1/ 1b., 45c; 1 ib., 80c: 2 lbs. 1.50 .

Magnetic Tack Hámmers-Each, 25c.

\section{Four Basket Crates}

For Peaches, Tomatoes, Plums, etc., 1 gallon to basket. Crates complete with 4 baskets, doz., $\$ 1.50 ; 25$ for $\$ 3.00$; 100 for $\$ 10.50$.

Baskets Only-Doz, 30c; 100, \$2.00; 500, \$1.75 per 100 Round Elm Baskets-Very strong, medium light weight, Briggs' Round Oak Stave Basket-Drop handle. '1/2 bu., each, 45c; doz., $\$ 4.75$; 1 bu., each, 50c, 6 for $\$ 2.75$. 1 pk., Market Baskets, $60 \mathrm{c}$ per doz.

$1 / 2$ bu. Market Baskets, 60c per doz.

\section{Fern Pots}

Seven-inch Fer'n Pots, 10c each; $\$ 1.00$ dozen; 8-inch Fern Pots, 15c each; \$1.50 dozen. Jardi-

nieres, 10c, 15c, 25c and up. of water-proof paper and are light, clean and unbreakable. Per $100 \quad 1,000$

$21 / 4$-inch Per $100 \quad 1,000 \quad$ Per $100 \quad 1,000$ $21 / 4$-inch ...\$0.60 \$5.00 $31 / 2$-inch...\$1.00 \$9.00

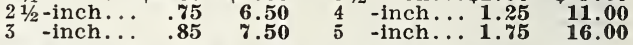

Plant Tubs-Painted Green

No. $0-20$ inch....\$1. 75 No. $1-18$ inch.... 1.60 No. $2-15$ inch... 1.50
No. $3-14$ inch... $1 . \mathbf{3 5}$ Japanese Air Plants

Greatest sensation of the age. These are beautiful little Fern-lik plants suitable for hang ing baskets, fern dis es, etc. and require no water. 'Don't fail to include one in your order. Each, 15c; 2 for 30c; 12 for $\$ 1.50$, postpaid.
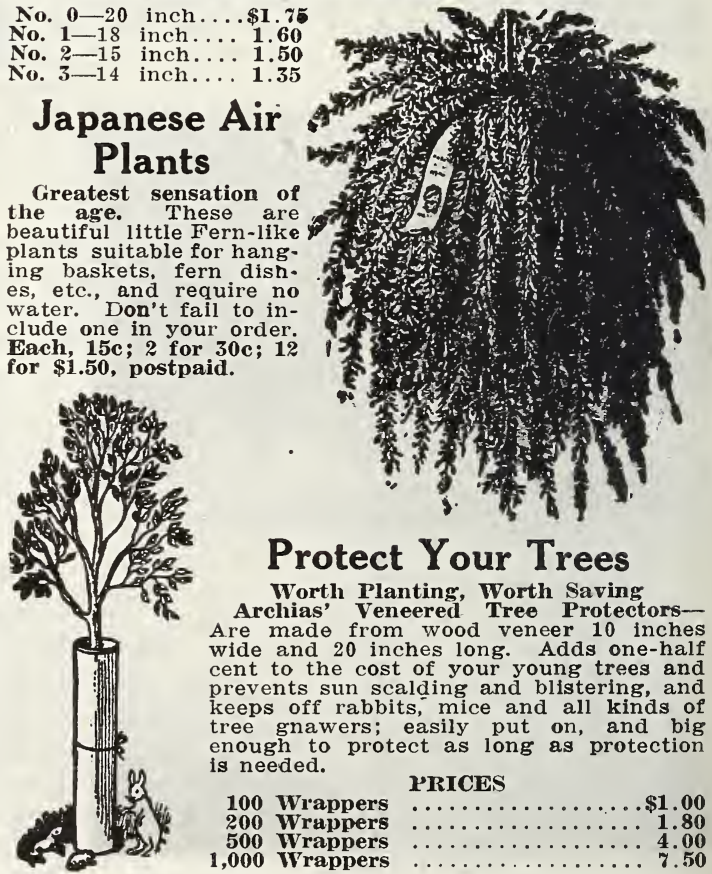

Protect Your Trees

\section{Worth Planting, Worth Saving}

Archias' Veneered Tree ProtectorsAre made from wood veneer 10 inches wide and 20 inches long. Adds one-half cent to the cost of your young trees and prevents sun scalding and blistering and prep off rabbits, mi and trees of tree gnawers, easily put on, and big is needed.

$\ldots \ldots \ldots \ldots \$ 1.00$

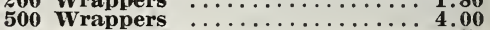
$\mathbf{1 , 0 0 0}$ Wrappers $\ldots \ldots \ldots \ldots \ldots \ldots \ldots \ldots \ldots, \mathbf{7 . 5 0}$ 
A R CHIA, SEED STORE, SEDALIA, MIS OURI

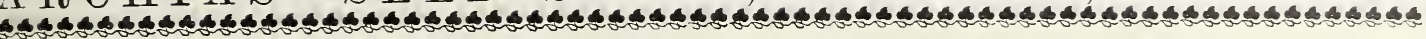
ARCHIAS' Wire Plant Stands New Pattern at Half Regular Price. All Our Stands are Painted Bright Green and Bronzed in Gold

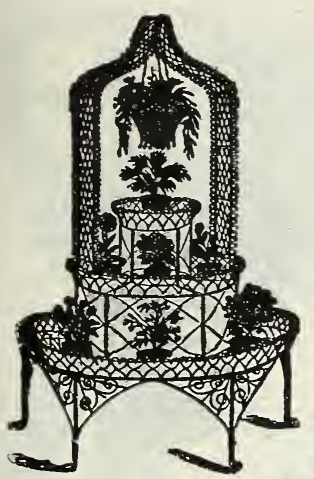

No. 5

No. 4-This is one of our most attractive stands. Holds about 30 pots; 48 inches wide, 31 inches deep, 41 inches high. Only \$4.00.

No. 5-Same stand as No. 4, with arch and hanging

basket, \$5.25. inches deep; shelves 39 inches long. Only \$4.00.

\section{Archias' Wire Flower Vase}

Made of heavy steel wire, painted green; neat, durable and attractive. An ornament to any lawn, veranda or porch. Also excellent for cemetery use, Will last many years; 16 inches cross top; 32 inches high. Each, only \$2.00; 2 for $\$ 3.75$.

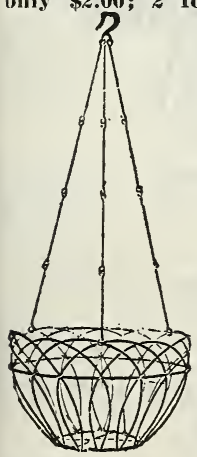

\section{WIRE HANGING BASKET}

With chain, 8-inch, 15e 10-inch, 25c; 12-inch, 35c 14 -inch, 40c each.

Rustic Hanging Basket -10-inch bowl, each, \$1.25. No. 28-Single Plant Stand-12 inches in diameter, 12 inches high to shelf. This stand is adapted for the display of specimen plants. Price, only men.

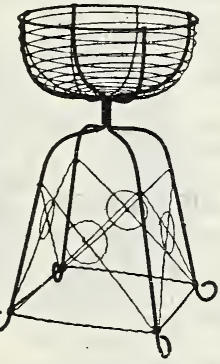

\section{Raffia and Reeds}

FOR FLORISTS ANI BASKET WORK

Raffia-Natural, 1/4 lb., 15c; 1 lb., 40c; 6 lbs., \$2.25. Raffia-Colored green, yellow, red, brown, black, white blue, purple, pink, canary, orange, blood red; all bright colors, 10c bunch; 3 bunches, 25e; 1 lb., \$1.25; 5 lbs., $\$ 5.00$

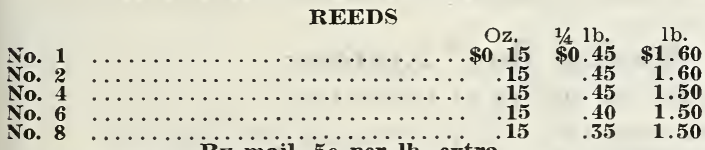

Raffia

Book on Basket Making $-40 \mathrm{c}$.

\section{LABELS}

Three Labels-Notched, 15c per 100; 95c per 1,000.

Pot Labels-Plain, 4 -inch, 25c per 100; $\$ 1.15$ per 1,000. 5 -inch, 30c per 100; $\$ 1.35$ per 1,000 .

Cane Stakes-For sticking peas, beans, plants, etc., 5 to

feet, 20c per doz; 25 for $35 \mathrm{c} ; 100$ for $\$ 1.00$

Tin Foil-Lb., 25c; 10 lbs., \$2.25.

Moss Sphagnum-Lb., 20c; bale, \$1.50.
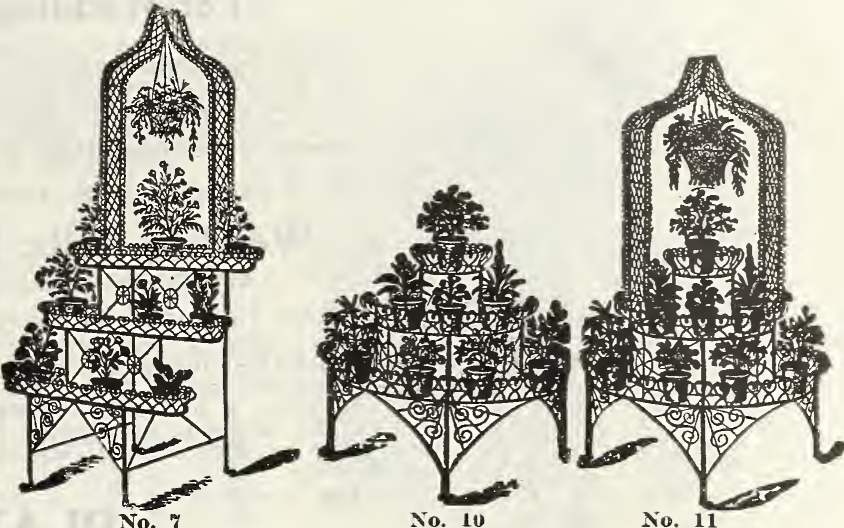

Yo. 7-Same as Vo. 6 with arch and basket, \$4.90.

No. 10-This half round stand is 3 feet high, 42 inches wide, 26 inches deep. Only $\$ 3.15$.

No. 11-Same as No. 10, with arch and basket, \$3.75. Your plants will look prettier on one of Archias' plant stands. Neat, durable, and guaranteed to please.

\section{Big Bargain Window Shelf}

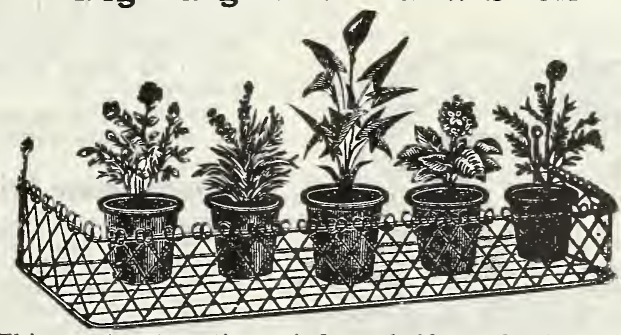

This neat, attractive window shelf, ready to put up to any window with two screw eyes. Made in three sizes: 33 inches long by 8 inches wide.............\$ \$0.75 36 inches long by 8 inches wide.............. 80 39 inches long by 8 inches wide.

TINNED FLOWER PÖ'T BRAC̈KE'T

Substantially made of steel wire and tinned after being made. Easily put up and instantly removed.

"A", $41 \frac{1}{2}$ inch, each, 10c

"B", $51 / 2$ inch, each, 15c

Order a half dozen

brackets for your win-

dows-you will like

them

Watering Pots - 25c,

$35 \mathrm{c}$ and $50 \mathrm{c}$ each.

Wheat Sheaves-75c each.

White Doves-\$1.25 each.

Wired Tooth Picks- $\$ 2.25$ per

box of 10,000 .

For wreathes, etc, best colors, 50c per

undle, 3 for $\$ 1$.

White Wax Tissue Paper-24x36-inch, $55 c$ per 100 sheets.

\section{Thermometers}

Hot Bed or Mushroom Bed Thermometers-Pointed brass bottom for plung

Dairy-All glass thermometers. Each, 50c; post paid, 60c.

Incubator- $\mathrm{M}$ a $\mathrm{g} \mathrm{n}$ if i e dube. Postpaid, $75 \mathrm{c}$

Common Japanned Tin Case7-inch, 20c; 8-inch, 25c; 10-inch, 35c: postpaid, 10c each extra.

Brooder Thermometer, postpaid, 35e.

Pruning Shears - Each, 35c; postpaid, $50 \mathrm{c}$

Thermostat-Florists' standard formose use. Each, \$5.00. Catalog of Thermometers on application.

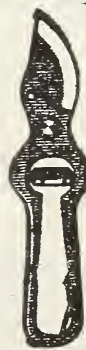




\section{ARCHIAS' CUT FLOWERS AND DECORATIONS}

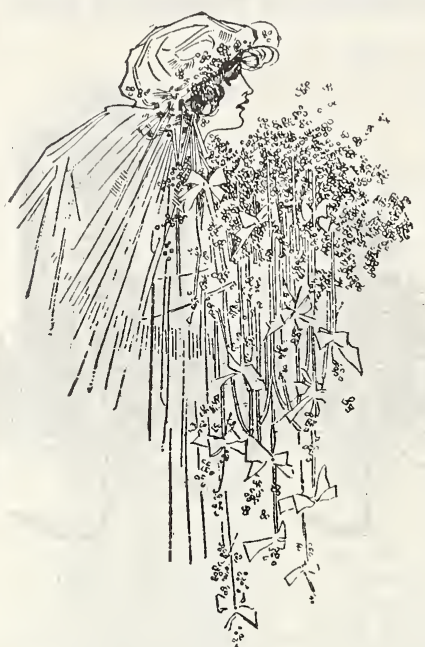

For Weddings, Banquets, Parties, Balls

Out-of-town flower buyers should remember that an established business, as ours, is in every way much better prepared to meet the wants of all purchasers than can be done by florists in smaller towns who do only a small business.

Wedding Bouqets $-\$ 3.00, \$ 5.00, \$ 7.50, \$ 10.00$ each and up.

Maid Bouquets $-\$ 2.50, \$ 3.00, \$ 3.50, \$ 5.00$ and up.

\section{Wedding Bells, Horseshoes}

And Other Apprprlate Designs.

Write for further information.

We make a speciality of BASKETS OF CUT FLOWERS-for Maids, Flower Girls, Gifts and Table centerpieces. These are very pretty and are put up in a hundred styles or designs appropriate to the occasion, at popular prices, in reach of all. Some at $50 \mathrm{c}$ to $\$ 1.00$; others at $\$ 1.50$ to $\$ 5.00$, or higher.

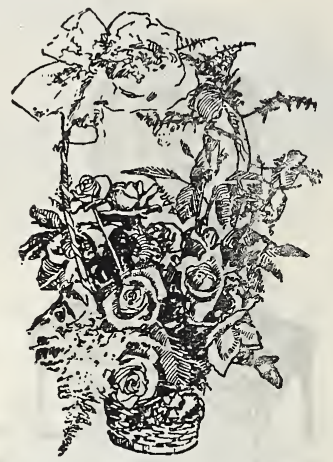

Nato.

\section{PLANT BASKETS}

These consist of choice bloming plants of special value. Some with Spring Bulbs, some with Azaleas and others of bright blooming Begonias, Baby Roses, or Spireas with their delicate, pleasing fragrance that is so appreciated in the sick room, and still others with graceful ferns, dracenas and palms. These are very lasting and cost from $\$ 1.00, \$ 2.00, \$ 3.00, \$ 5.00$ and up.

We make a speclalty of decorations for weddings, balls, parties, etc.

\section{Approximate Prices Cut Flowers}

Prices on cut flowers vary according to season and scarcity of flowers. Special days like Easter, Decoration Day, Thanksgiving and Christmas the demand for flowers is greatest, consequently prices are higher. Will always fill orders as low as we can afford.

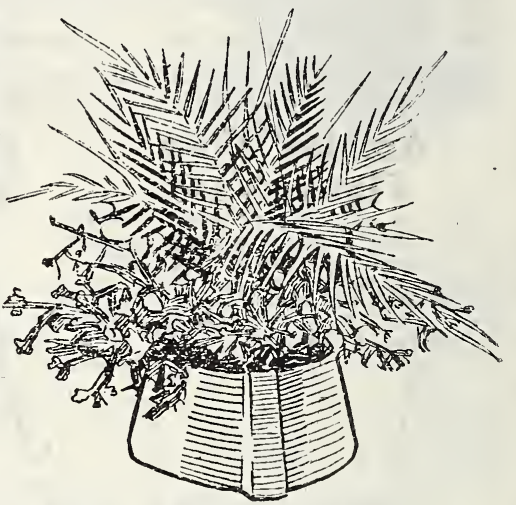

Tea Roses-White, pink, red, yellow, $\$ 1.00$ to $\$ 1.50$ per dozen.

American Beauties- $\$ 4.00$ to $\$ 6.00$ per dozen.

Carnations-White, pink, red, $75 \mathrm{c}$ to $\$ 1.00$ per dozen.

Violets-Per $100, \$ 1.00$ to $\$ 1.50$; holidays, $\$ 2.00$.

Lilies-Easter kinds, and callas, December to May, inclusive, each, $25 \mathrm{c}$; per dozen, $\$ 2.50$ to $\$ 3.00$.

Chrysanthemums--September, October, November and December, selected, $\$ 1.00$ to $\$ 3.00$ per dozen; specimen flowers, $25 \mathrm{c}, 50 \mathrm{c}$ and $75 \mathrm{c}$

Daffodils and Narcissus-White and yellow; November to May, $75 \mathrm{c}$ to $\$ 1.00$ per

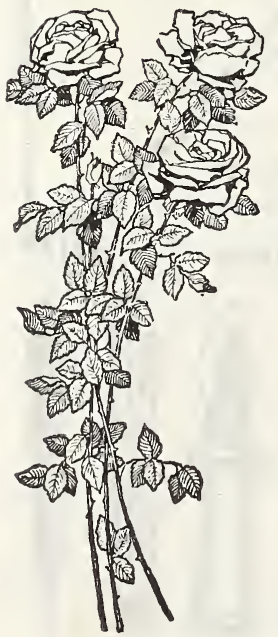
dozen.

Lily of the Valley Sprays $-75 \mathrm{c}$ to $\$ 1.00$ per dozen.

Roman Hyacinths-White; November to May, $75 \mathrm{c}$ to $\$ 1.00 \mathrm{per}$ dozen.

Smilax Strings -4 to 6 feet long; each, 25c.

Asparagus-Sprays, $50 \mathrm{c}$ dozen; strings at $50 \mathrm{c}$ each.

Bourvardias, stevias, treezias, pansies, marguerites, daisies, blue forget-me-nots, mignonettes, peonies, sweet peas, asters, coreopsis, gladiolus, lilies, tube roses, hydrangeas and other choice cut flowers at reasonable prices.

\section{Archias' “Dollar Box" System}

A New Feature for the Benefit of Flower Lovers.

Our "Dollar Boxes" of Flowers make exceptionally lovely gifts. They contain a good assortment of seasonable blossoms, and are put up fresh for each order.

Delivered anywhere in the city or by parcel post to your friends or family, no matter what the distance. WUEANTEE ALL THE RISK AND GUARANTEE Price, prepaid, just $\$ 1.00$.

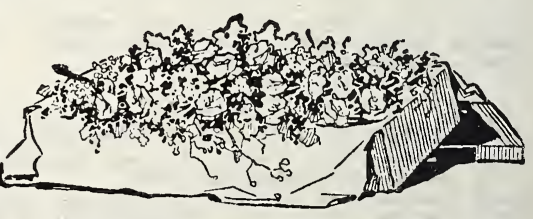


ARCHIAS, SEED STORE, SEDALIA, MISSOURI

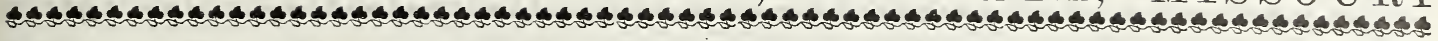

\section{ARCHIAS' FUNERAL DESIGNS AND SPRAYS}

Below we make you a list of standard designs and sizes. We have frames in stock for all sizes listed. When no mention is made of color we use white and green of most seasonable and appropriate flowers, with sometimes a
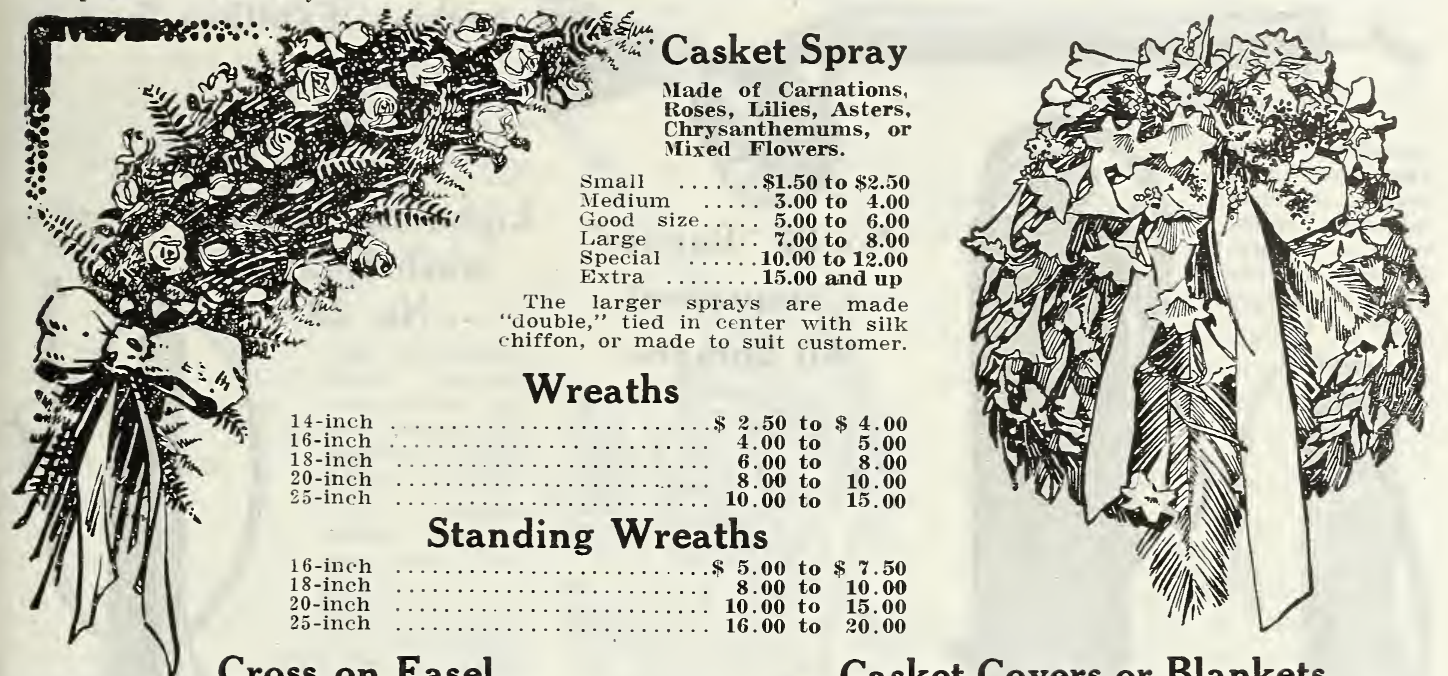

Cross on Easel

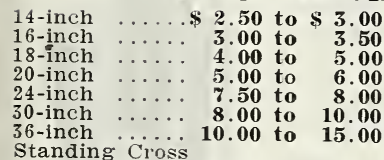

with base .. 10.00 to $\mathbf{5 0 . 0 0}$

\section{Gates Ajar}

20 -inch $\ldots \ldots . \$ 7.50$ to $\$ 10.00$

30-inch $\quad \cdots \ldots .10 .00$ to $\mathbf{1 5 . 0 0}$

Larger, up to.........

\section{Pillow}

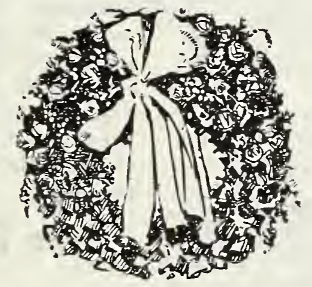

14-inch

16-ineh

18-inch

22 -inch

Larger, upivards to

Broken Column

25-inch

30 -inch

42-inch

Larger.

14-inch

16-inch

18-inch

24 -inch

Anchor and cross, prices as above.

\section{Broken Wheel}

16-inch

18-inch

20 -inch

30-inch

36 -inch

15 -inch

18 -inch

21 -inch

25-inch

16-inch

18 -inch

24 -inch

Harp or Lyre on Bas

Address orders for Cut

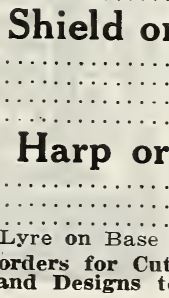

Anchor on Easel

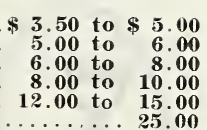

.$\$ 7.50$ to $\$ 9.00$ 10.00 to 12.50

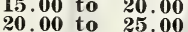

$$
\text { F1 }
$$

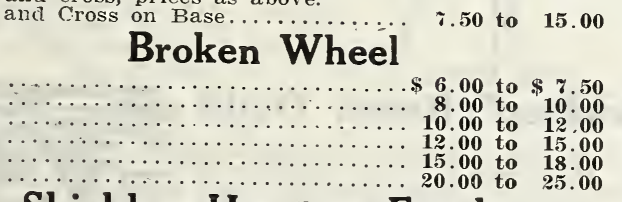

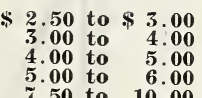
7.50 to 10.00 7.50 to 15.00 6.00 to $\$ 7.50$ 10.00 to 12.00 15.00 to 18.00 Easel

$\$ 3.00$ to $\$ 5.00$ 6.00 to 750 8.00 to 10.00 12.00 to 15.00 Lyre on Easel

$\$ 3.00$ to $\$ 5.00$ 5.00 to 7.00

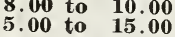

Casket Covers or Blankets

Made to fit casket and drape on all sides. Faced with satin, \$10.00, \$12.00, \$15.00, \$25.00 and up, according to

\section{Sickle and Sheaf of Wheat}

12-inch sickle.

16 -inch sickle.

Star

$\mathbf{3} .50$
$\mathbf{5 . 0 0}$
$\mathbf{7 . 5 0}$

Plain or Eastern Star on Easel

$\$ 3.00$

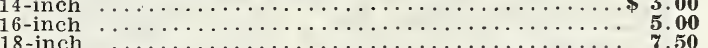

Star on Base Crescent and Star on Base

14 -inch

16 -inch

$\$ 5.00$ 6.00
7.50

$\$ 8.00$ to 10.00

A General List of Lodge and Society Emblems in Funeral Designs

For convenience we name here most of the design generally called for in funeral work. We shall be glad to tell you upon request anything you want to know about you want something not listed here let us know.

\section{Lodge and Society Emblems}

A. O. U. W Design .......... $\$ 5.00$ to $\$ 10.00$ Amalgamated Association Iron and stee ${ }^{\$}$

Brotherhood Engineers

Brotherhood Firemen

B. P. O. E. Design

Christian Endeavor Society Design.

F. O. E. Design

F. and A. M. Design

G. A. R. Badge Design

Knights of Pythias

Loyal Order IIoose

M. W. A.

5.00 to 10.00 5.00 to 10.00 5.00 to 10.00 10.00 to 35.00 5.00 to 10.00 4.00 to 8.00 5.00 to 10.00 5.00 to 10.00 5.00 to 10.00 10.00 to 25.00 5.00 to 10.00 5.00 to 10.00 5.00 to 10.00 Odd Fellow' Three Links on Panel or Plllow ........ 5.00 to 25.00 Red Men .......................................... Switchmen U. of $N$. A. . . . . . . Sheet Metal Workers' Union ........... 5.00 to 10.00 Woodmen of World .................. 5.00 to 10.00

The above designs are furnished with ribbon bearing the name of the organization. We can make you anything out of flowers, and our work is made with fresh flowers.

Our prices are reasonable. We pay express charges on orders of $\$ 5.00$ or more within 500 miles of Sedalia. No charge for packing. 
GROW "S URE SEED S', PLA N T A N D TREE S

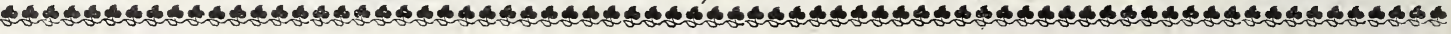
If You Have Not Had Successful Fruit Crops-Try Spraying

Trees cannot thrive when infested with the different kinds of sucking, biting and chewing insects. They cannot produce high grade fruit-nor much of any kind. Systematic spraying will not only increase the quantity of your
fruit crop but will wonderfully improve the quality as well. Thousands of fruit growers owe their present success to a good spray pump-after they had practically given up the hope of ever getting a good crop again.

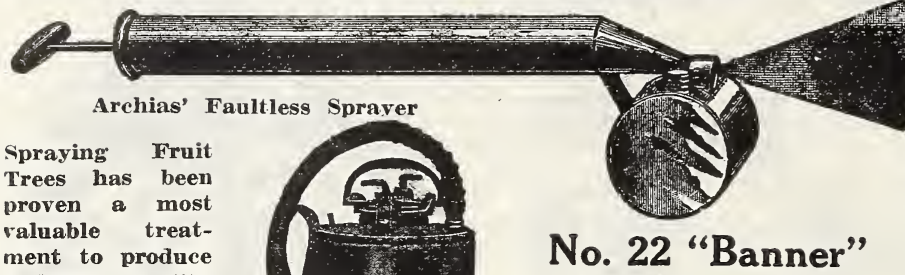

better qualit and much larger vields of fruit.

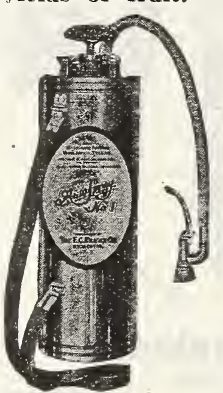

No. 1

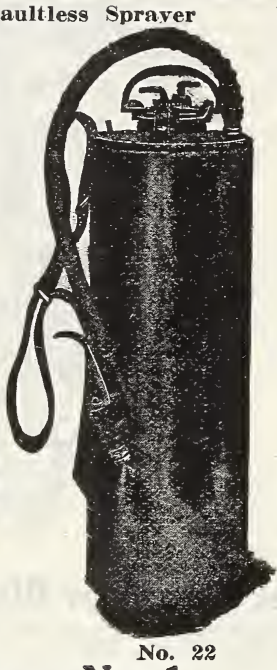

No. 1

Holds four grallons. Price, brass tank, complete, only $\$ 9.50$.

Brass Tank with Auto Pop (recommended), $\$ 10.00$.

No. 1 Galvanized Tank, \$7.00.

No. 1 Galvanized Tank, with Auto Pop, \$8.00.

Extension Pipe, Brass, 2 ft. length, 60c.

Elbow Extension, Brass, 75c.

Description circular on the "Auto Spray" and spray calendar sent on request.

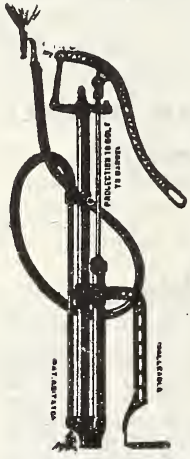

Fig. 632. Lere Fig. 632

\section{Archias' Self-Setting Mole Trap}

THE BEST "CATCH" ON THE

\section{Simplest Surest Safest}

It is made of all steel and heavily tinned, which makes it a very attractive as well as a durable trap. The spears are made of spring steel and are therefore smaller than those made of soft steel, piercing a mole

\section{Archias' Faultless Sprayer}

Capacity, one quart. The best sprayer made. Throws a spray as fine as mist, rendering the use of strong solutions safe on tender follage plants; it forces the fluid into every crevice, without using half the (a) sprinkler. (See cut). Price, 60c; 3 for $\$ 1.50$.

\section{Compressed \\ Air Sprayer}

No. 22 Banner co mpressed air sprayer is made with double seamed head to stand a heavy pressure of air; it is 7 inches in diameter, 21 inches high, and holds about four gallons. The tank is provided with a safety valve to prevent over pressure.

The pump is made of heavy brass, and screws into the center of the head, with a machine cut thread. The pump handle is used for charging the sprayer, and by a half turn locks into pump casting for screwing pump into tank. In this position it is also used for carrying the used for

An adjustable shoulder strap with snap at each end, and lever self-cleaning nozzle is furnished.

This sprayer is adapted to spraying potato vines description trees, ef every description, trees, shrubbrice, $\$ \mathbf{\$} \%$.00.
Lightning White-

\section{Whit}

wash Sprayer poultry and stables easily, rapidly with th e "Lightning W h it e wash sprayer." It kills lice and vermin. Can't clog. Also for $\mathrm{spr}$ a y i $\mathrm{g}$ $\mathrm{t} r$ e e $s$, washing wagons, etc. Is made of heavy galvanized iron, furnished wit h nozzle for throwi $\mathrm{n}$ either a stream or spray, and is well made throughout.

Price, only $\$ 2.25$, postpaid.

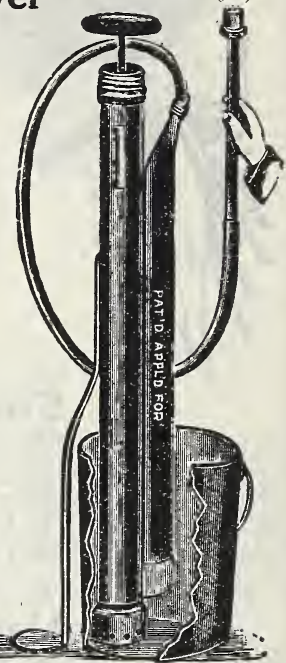

Star Force and Spraying Pump

Throws a stream 40 feet and makes a spray as fine as mist, all with one nozzle. Has no equal for spraying trees, flowers, lawns, gardens or bath houses. Spray your cattle, hog or poultry houses with it. Handy for washing windows, muddy horses, buggies or autos. Used by veterinarians for cleaning, dressing and giving injections, etc. Unequaled for whitewashing.

The "Star" is all solid brass except handle, foot is all solid brass except acting piston. acting piston. Agitator at bottom. Has non-clogging spraying device. No out. Has detachable foot brace; may be used in bucket, barrel or milk can. Price, only $\$ 4.00$.

George Miller, California, M o., writes: I am well pleased with the pump you sent me and wish to thank

Fig. 633.

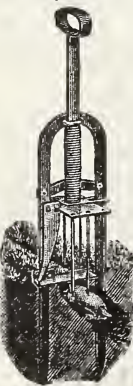

For bots, shoes, rubbers, harness and tinware Comprises four iron lasts-men's boys', women's and children's-iron stand for lasts, hammer, lknife, peg awl, sewing $z w l$, stabbing awl, wrench for peg awl, botle leather cement bottle rubber cement, bundle bristles, ball shoe thread, ball shoe bux linch nails, four pairs heel plates, assortedsinch nails, four pairs heel plates, assorted, ix marness blotted rivets, assorted, and rivet set for same, harness and belt punch, soldering iron and handle, bar solder, bar resin, bottle soldering fluid, directions for half-soling and soldering. All in good case weighs, complete, 20 pounds. Set, \$1.25.

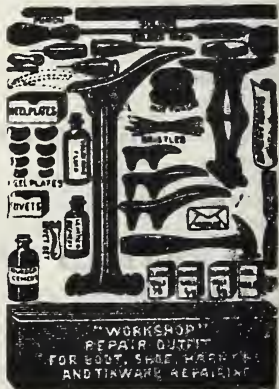




\section{Garden IRON AGE Tools}

We show here only four of this celebrated line, of which there are over thirty combinations from which to choose what suits your purpose best, whether for home, farm or market gardening.

IRON AGE Garden Tools are built with good strong steel frames and 16-inch wheels which ride furrows easily. All of them push easily and are used by men, women and children. Equally valuable in small gardens as well as large. Tools, handles, etc., can be adjusted in many ways to suit the work. The seeders are accurate and sure, dropping the seed in plain view. These garden tools enable you to keep your garden in fine growing condition with very little work and time. With them you can raise a large, interesting garden wi t h o ut back-bending, hand-seeding and hoeing -you can cultivate your garden farm-like but without the horse. They save ground because you can work in long narrow rows, allowing only enough ground to grow the crops properly.

Every general farmer should have at least one combination for that important part of his farmthe garden-which makes possible better living for less money.

City men-the mechanic, laborer, professional \begin{tabular}{|l|l} 
No. & $\begin{array}{l}\text { man and clerk - can } \\
\text { with small expense and } \\
\text { little work provide } \\
\text { their tables with an }\end{array}$
\end{tabular} abundance of fresh vegetables and forget the present high cost of living.

No. 306 Combined Hill and Drill Seeder and single and Double Wheel Hoe. Four tools in one. Prepares the soil, opens and closes the furrow, drops the seed, firms the ground and keeps the garden in shape with hoes, cultivator teeth and rakes.

Packed weight, 57 lbs. Price, \$19.00.

No. 301 Double and Single Wheel Hoe. Same as No. 306 but without the seeder. Seeder can be purchased later if wanted. Packed weight, $40 \mathrm{lbs}$. Price, \$11.00.

No. 303. Same as No. 301 except with side hoes only and without vine lifters and other tools. Price, $\$ 7.75$.

No. 320

No. 313. Same as No. 301 , except without the plows. Price, $\$ 9.50$.

No. 19C Wheel Hoe and Cultivator. Large 24-inch steel wheel. Special working tools including landside plow. Does not take seeder. Packed weight, 22 lbs. Price, $\$ 6.00$.

No. 320-single Wheel Hoe, A low-priced, lighter weight tool than No. 301, but strong and durable, capable of doing all necessary cultivating between the rows-hoeing, furrowing, ridging, weeding, leveling, etc.-in any home or market garden. Sixteen inch steel wheel with 13/4-inch rim. Adjustable for height. Can be fitted with seeder attachment. Packed weight, 30 lbs. Price, $\$ 9.00$.

No. 321. Same as No. 320 except with side hoes only and without vine lifter. Price, $\$ 6.25$.

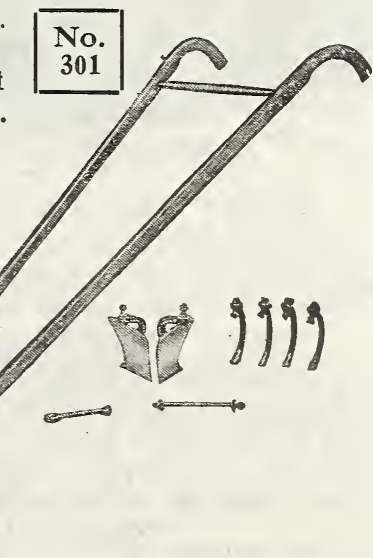

Combined Hill and Drill Double and Single Wheel Seeder, and Wheel Hoe, Hoe
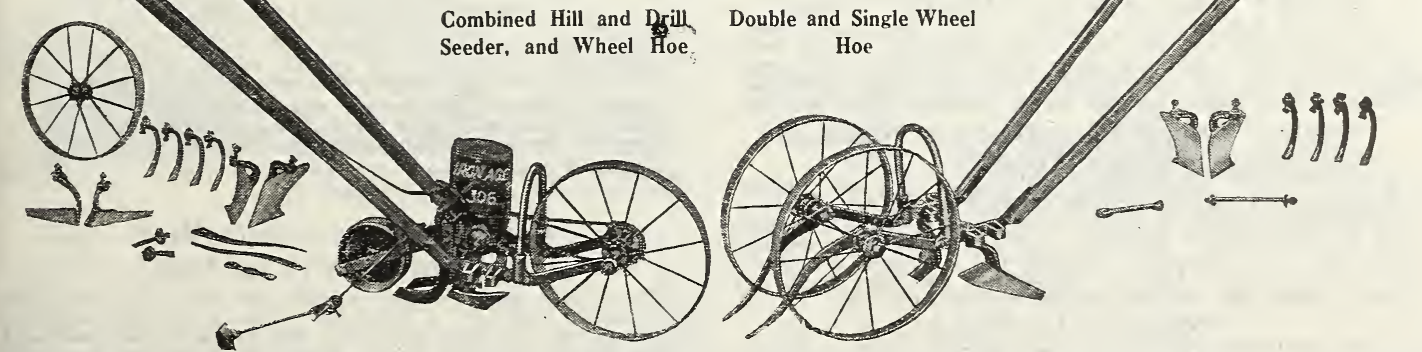

ASK FOR IRON AGE GATALOG ON GARDEN DRILLS AND PLOWS 


\section{Archias' Boss}

\section{Garden Cultivator and Potato Digger}

This new adjustable Garden Cultivator has six plows made of crucible spring steel, oil tempered, weighs but three pounds. In planting and cultivating it takes the place of spade, hoe, rake and marker, and
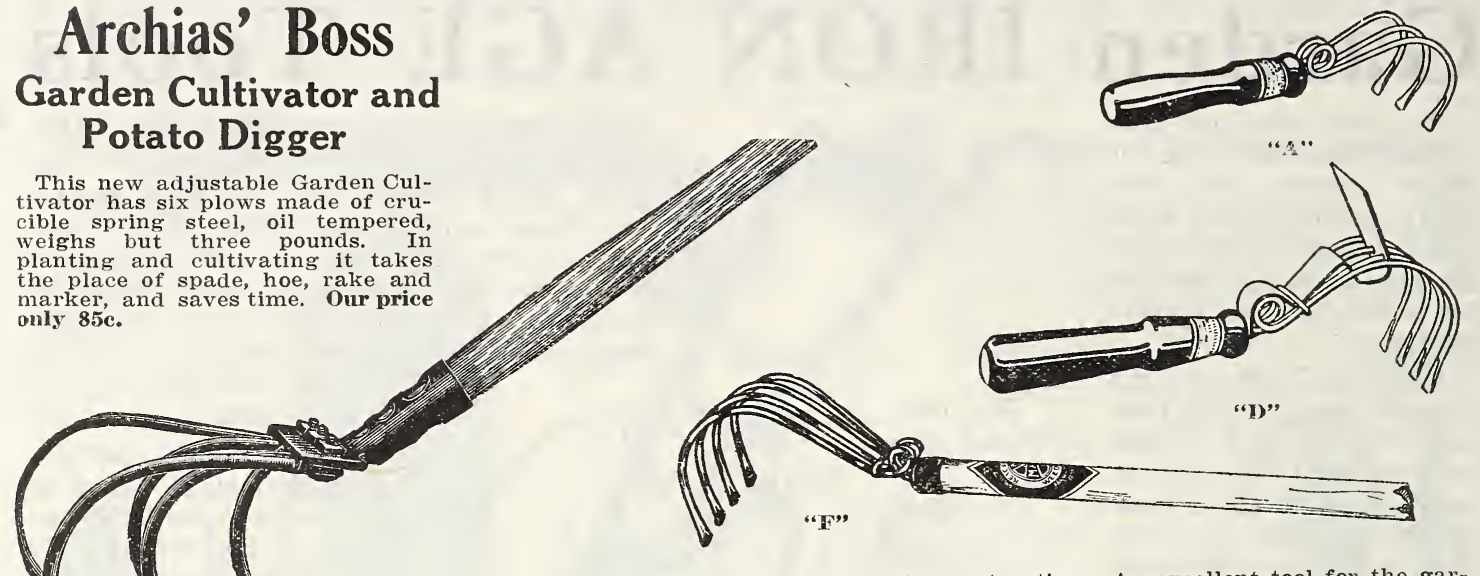

Light in weight; strong in construction. An excellent tool for the gardener, farmer, florist and nurseryman.

Style A, 15c each; postpaid, 25c each.

Style D, 35c each; postpaid, 45c each.

Style F, 45c each, by express.

Style H, 85c each, by express.

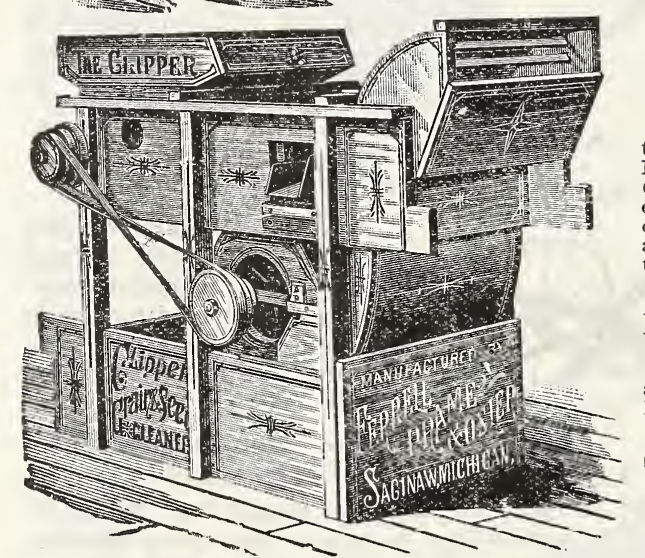

\section{"Clipper" Grain and Seed Cleaner Number 1B}

The manufacturers of the "Clipper Mill" have greatly improved their old No. 1, and in future this size will be known as No. 1B. No $1 \mathrm{~B}$ Clipper has many new features. The assortment of screens (twelve with this, only ten with the old), are much better, and will enable the farmer to grade his wheat, oats, etc., for sowing, and his enable the farmer to grases. The directions for using the screens corn for planting purposes. The directions could make an error in their arrangement for cleaning grain, seed, etc.

Every "Clipper Mill" is guaranteed, both as to material and worimanship: will clean all kinds of seed and grain faster and better than any other mill on earth.

The No. 1B Clipper Cleaner, with twelve screens is the best allaround farm mill made. Give it a trial and you will use no other. Endorsed and used by state and government experimental station.

Our screens are so arranged as to be in plain view and of easy access to the operator while machine is in operation.

Capacity, 40 bushels of wheat or 12 bushels clover per hour.

We will deliver this mill at your nearest railroad station, freight paid, for only $\$ 31.00$.

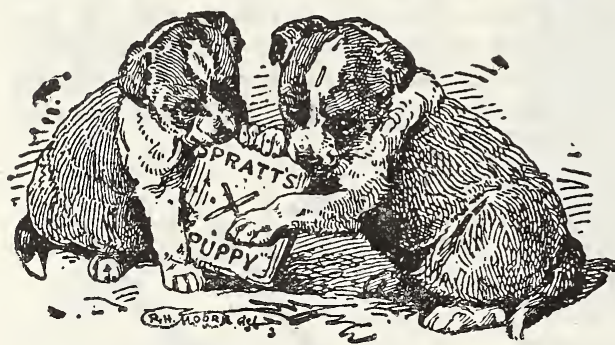

\section{Dog And Cat Food Supplies}

"Spratt's" Meat "Fibrine" Vegetable Dog Cakes

The standard dog food. Used at the leading kennels and dog shows throughout the world. A staple and constant food for all breeds of dogs. Prices, bags, 100 lbs., $\$ 10.00 ; 50$ lbs., $\$ 5.25$; 45 ibs. $\$ 2.75$. Cartons, $35 \mathrm{c}$ and $70 \mathrm{c}$.

Note: If required will

be supplied in kibbled form, i. e., broken and sifted, as fed at leading shows, at same price as above.

“Spratt's" Meat Fibrine “Terrier" Cakes

Specially prepared for terriers and other active dogs. Eaten with avidity; they are easily digested, make bone and muscle, and not fat, thus insuring the true terrier qualities of energy and action. Prices, Bag, 100 lbs.,
$\$ 11.00 ; 50$ lbs., $\$ 6.00 ; 25$ lbs., $\$ 3.25$. Cartons, 35c and 70c.

"Spratt's" Puppy Biscuits. The Standard Puppy Food A perfect and whole food for puppies of all breeds.
Puppies should be started on these biscuits when about one month old, and they should be continued until such time as their teeth becomes sound continued until such when they are about six months old. Follow directions when they are about six months old. Follow directions 50 lbs.; \$2.75 per 25 lbs. Cartons, 35c and 70c.

\section{"Spratt's" Cat Food}

A complete food for cats. Used at the leading cateries throughout the world and daily becoming more popular among the fancy. Prices: Bags, 50 lbs., \$5.50; 25 lbs., $\$ 3.00 ; 10$ lbs., \$1.50. Cartons, 20c and 35c.

\section{Spratt's Patent Dog Soap}

Kills fleas, prevents mange and other skin diseases. Tils fleas, prevents mange and other skin diseases. smooth and glossy. Price: 50c per cake, by mail.

Spratt's Patent Distemper Cure-Box, 75c.

Spratt's Patent Mange Cure-Box, 50c.

Spratt's Patent Worm Remedy-Box, 50c.

Sulpho-Tobacco Soap-An excellent soap for washing dogs and cats. Pkg., 10c and 25c.

\section{Catnip Ball and Catnip Mice Exercising Toys for Cats}

They can't let it alone; ridiculously amusing; positively beneficial; will last a lifetime. Catnip and other herbs, nature's own remedy for cats. Price, each, 15c, postpaid.

Cat Bells-Made of brass. Each, 5c; 3 for 10c, postpaid.

Writo for catalog, "Dog Culture," with practical chapters on the feeding; kenneling and management of dogs; also chapters on cats. 
A R CHI A S SEED STORE, SEDALIA, MISSOURI

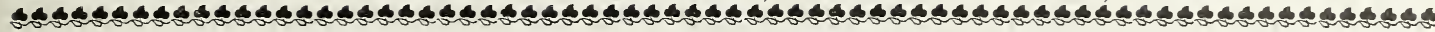

\section{ARCHIAS' CANARY BIRDS}

This is most popular of all birds, as well as the most satisfactory songsters. These birds are very hardy, perfectly happy in the little cages, and are famous for their clear, beautiful song. Each bird is tested and known to be in full song before leaving the store, and we guar$\$ 1.50$ each.

\section{New Valuable Bird Books}

Feathered Pets--By Chas N. Page. A most complete new book on Canaries, Parrots and all kinds of cage birds. 140 pages, paper cover, $25 \mathrm{c}$

Canary.Breeding and Training-By the author of Feathered Pets. Tells the whole story. 80 pages, 25c.

American Bird Fancier-By D. J. Browne and Dr. Fuller. On how to breed, rear and care for song and domestic birds. All who own valuable birds, or wish to do so, will find the new Fancier indispensable. Illustrated, 116 pages, Paper cover, 50c.

Canary Birds-A manual of useful and practical information for bird keepers. 110 pages. Paper cover, price, 50c.

Books on Parrots and Other Talking Birds-Their Food, Care and Training

The most complete and best illustrated parrot book on the market. Price, only 25c, postpaid.

\section{Bird Supplies}

First-Class Goods at Lowest Prices

Nesting Food-An egg food for young birds which will keep indefinitely, and which is cheaper than eggs; box, $25 c, 3$ boxes, 65c.

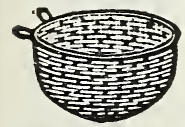

Bird Nesting-Prepared of hair moss and other material for birds to build their nests.

Per pks., 10c; 3 for 25c, postpaid.

Wire Bird Nests-10 each; 3 for $25 \mathrm{c}$.

Willow Bird Nests-10c each; 3 for $25 \mathrm{c}$.

\section{Bird Seeds}

Our Bird Seed is strictly fresh and clean and our pack-

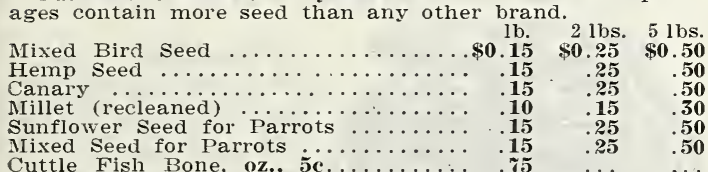

If wanted by mail, add for postage at zone rate.

\section{BARGAINS IN BIRD CAGES \\ Elegant Brass

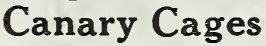

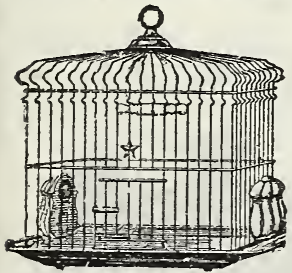

A neat and durable pattern and the best brass cage on the market. Made in 6 sizes.

No. $470, \quad 9 \quad x 6$ in $\ldots \ldots \$ 1.50$

No. $471,91 / 2 \times 61 / 2$ in ..... 1.85

No. $472,101 / 8 \times 71 / 8$ in .... 2.25

No. $473,103 / 4 \times 734$ in $\ldots \ldots .2 .65$

No. $474,113 \% \times 8 \% 8$ in

3.25

\section{Brass Canary Cages}

With Wire Brass Guard to prevent birds spilling seeds.

No. $2470,9 \mathrm{x} 6$ in....\$2.25

No. $2471,91 / 2 \times 61 / 2$ in.... 2.60

No. $2472,101 / 8 \times 71 / 8$ in.... 2.85

No. $2474,11 \frac{3 / 8 \times 8 \%}{4}$ in.... 3.50

No. $2475,12 \times 9$ in .... 4.00

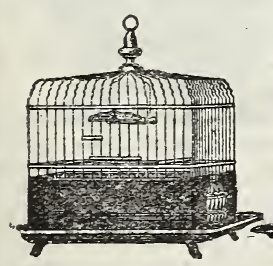

No. 2271
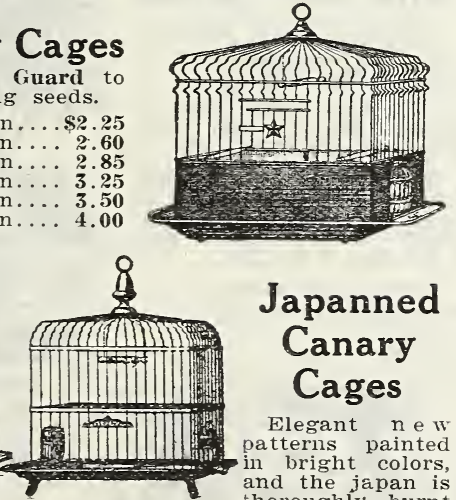

Japanned Canary Cages patterns painted in bright colors, thoroughly burnt on.

With brass wire guard, to prevent birds spilling seed hulls on the floor.

No. Each $2271,91 / 2 \times 6 \frac{1}{2}$ in ....\$1.75 $2272,10 \times 7$ in .... 2.75 $2273,10^{1 / 2 \times 71 / 2}$ in..... 2.50 $2275,113 / 4 \times 834$ in..... 3.0 $275,113 \frac{1}{4} \times 93 / 4$ in . . . . 2.00

Same as shown in cut without seed guard.

No. $270,9 \times \times 6$ in ...\$\$1.15 $271,9 \frac{1}{2} \times 6 \frac{1}{2}$ in ..... 1.35 $272,10 \times 7$ in ..... 1.50 $273,10 \frac{1 / 2 \times 71 / 2}{11} \ldots \ldots \ldots \mathbf{1}, \mathbf{6 5}$
Elegant $n$ e w

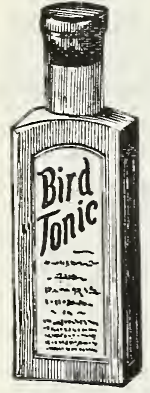

Parrot Food A preparation made of spices, dried fruits, etc.
This diet will keep the parrot in brilliant plumage and health. Pkg., 15c.

White Bird Gravel-10c pkg., 2 for $15 \mathrm{c}$.

Red Gravel--The finest and best on the market. lb. bag., 10c; 2 for $15 \mathrm{c}$

Crushed Pearl Shell-5e lb., 6 lbs., $25 c$.

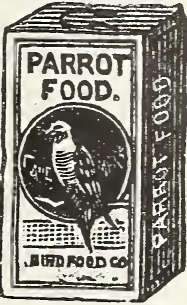

Bird Tonic-A valuable medicine for colds and other disorders of birds. Simply put it in the drinking ${ }^{-}$cup. Large bottle, 25c.

\section{Bird Manna}
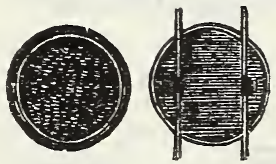

Great moulting season food birds are very fond of it; a feed pkg., 15c; ; for combined. Bird Bitters-Bottle,

Cayenne Pepper -4 oz., $10 \mathrm{c}$

Moulting Peppers-Pkg., 25e.

Insect or Mite Powder for Birds-Pkr., 50

Insect Powder Bellows-10c each; 3 for $25 \mathrm{c}$.

Bird Cage Hooks-3 styles, 15c and 20c each.

Bird Cage Springs--Solid brass spring and chain, only

Double Breeding Bird Cages

elow we offer you three of the finest breeding cages made. We sell hundreds of these to breeders. Birc breeding is interesting whether as a matter of experiment of for profit.

Removable trays and partitions. Complete with nests, seed cups and perches.
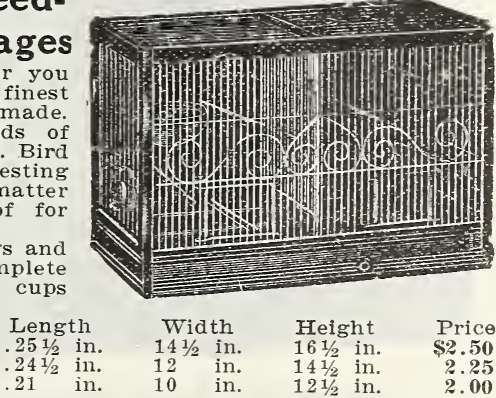

No. 1 $251 / 2$ in

Width

$14 \frac{1 / 2}{2}$ in.

Height 12 in.

$161 / 2$ in.

$141 / 2$ in

Price

$\$ 2.50$

No. $\frac{2}{3}$

\section{Extra Se}


GROW "S URE SEED S," PLA N T A N D T RE S

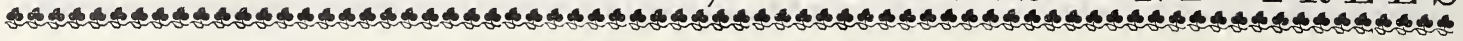

\section{Archias' Gold Fish Department}

\section{Price List of Gold Fish}

Chinese Gold Fish-Small size, 15c each; 4 for 50c; doz. $\$ 1.25$; medium size, 20c each; 3 for 50c; doz., $\$ 1.75$; lurge size, 25c to $35 \mathrm{c}$ each.

Silver Fish-Darker than gold fish, and nice for a valiety. Each, 15c; 2 for 25c. Larger ones, 25c to 35c each.

Oriole Fish-These are gold fish which are beautifully variegated golden red and clear black. Medium size, 25c each; 5 for $\$ 1.00$. Larger size, 25c to $50 \mathrm{c}$ each.

Pearl Fish-These elegant fish are either of clear, peary whlte ings. Medium size, 25c each; 5 for $\$ 1.00$. Extra large, $35 \mathrm{c}$ to $50 \mathrm{c}$ each.

Comet Fish-Medium size, 35c each; 3 for $\$ 1.00$. Large size, $40 \mathrm{c}$ to $50 \mathrm{c}$ each.

Japanese Fantail Fish-These are bred from the imoorted Japanese fish and are very handsome. Price, according to shape and color, $35 \mathrm{c}$ to 50c each. Some extra choice, 60c to $\$ 1.00$ each.

Japanese Fringe Tails-Undoubtedly the most beautiful and gorgeous flsh known. We offer some elegant specimens in assorted colors at 75c, $\$ 1.00, \$ 1.50$ and $\$ 2.00$ each.

Telescope Fish-Flnest Chinese and Japanese stock, having eyes that bulge out like telescopes, with single and double talls, 59c to $75 \mathrm{c}$ each.

Tadpoles-Used to keep the water pure, 10c each; $\mathbf{3}$ for 25c.

Fish Buckets or Pails-For shlpping fish, 15c extra.

\section{Aquariums and Globes}

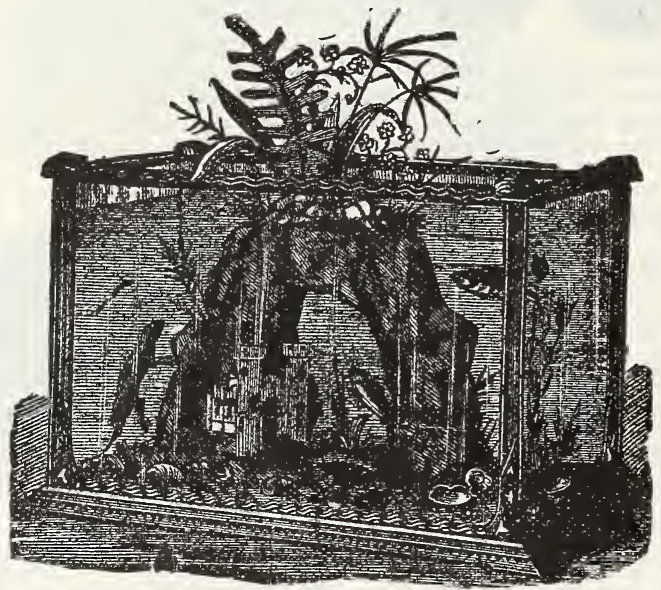

\section{Archias' Boss Aquarium}

\section{SLATE BOTTOMS}

No. 10, holds about 3 gallons............\$3.50 No. 11, holds about 5 gallons............... No. 12, holds about 8 gallons...........

Notice-These prices on Aquarlum and Globes do not include cost of conterits as seen ln cut.

\section{Floating Aquarium Ornaments}

No.
3135, Swan .

\section{Bargain Aquarium Collection}

\begin{abstract}
One No. 11 Aquarium, 1 No. 8 Botanic Arch, 6 Gold Flsh, 1 Pearl Fish, 1 Orlole Fish, 1 bunch of water plants, 1 package aquarium sand, 1 package aquarlum shells, 1 Book on Gold Fish, 1 package Flsh Food, 1 pail for Flsh Food, 1 pail for shipplng fish. Thls grand collection (worth $\$ 8.00)$, packed and deat Sedalia for only $\mathbf{\$ 6 . 5 0}$.
\end{abstract}

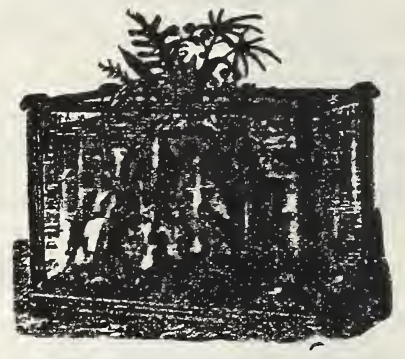

Just what you want for your home, office or store wlndow.

\section{Fish Food}

Archias' Celebrated Wafer Fish Food-The best food for all kinds of gold fish. This we lmport from Europe, where they make the best quallty and of the purest materials. Price, 10c per box; 3 for 25c; $\$ 1.00$ per doz., postpaid.

\section{Our Great Special Offer $\$ 2.15$}

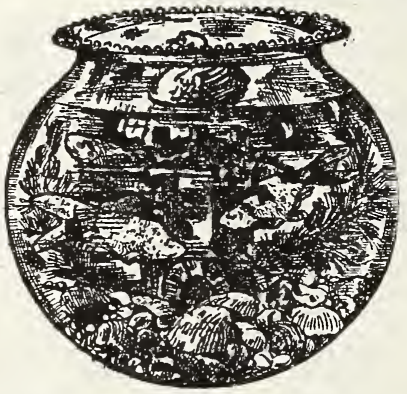

This beautiful "Parlor Collection," consistlng of one 8-quart globe, 2 fancy gold fish, 1 pole 1 fan flsh, $_{2} 1$ tadpko mlyed shels 1 . fish. plant 1 , 1 bunch plng fish and 64-pagpook on Care of Gold Fish. Boxed and packed complete ready for shipment, only \$2.15. Just the thlng for the school room, library or offlce.

\section{Plants for Aquar-} iums and Globes

Aquarium Moss (Cabomba)-Per buncl, 10c; bunches for 25c.

Cyperus-Umbrella plant. Each, 15c; 2 for $25 \mathrm{c}$ Large plants, 25c each.

Water Hyacinth-A beautiful floating plant that blooms like a hyacinth. Hasily grown. Fach, 20c:

2 for $35 \mathrm{c} ; 6$ for $75 \mathrm{c}$.

Postage on above $n$

2c each extra.

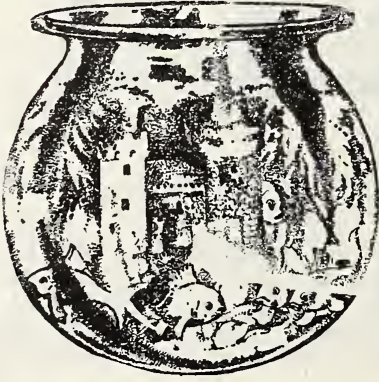
1 qt., 20c; 2 qts., 35c; 4 qts., 60c; 6 qts., 85c 8 qts., \$1.00; 10 qts.,

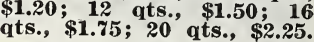
Footed Fish Globes-8 qts., $\$ 1.40 ; 12$ qts., $\$ 2.50$; 16 qts., $\$ 2.75$; 20 qts.,

The above globes are made of the best glass and elegant designs.

Aquarium $\mathrm{C}$ e m e n tPrice, 4 oz. pkg., 20c; 8 oz. pkg., 30c; 16 oz. plkg., 50c, postpaid.

Full directions with each package. 


\section{Aquarium Castles}

A nice castle will add more to the beauty of an aquarium or fish globe than anything else you can choose. We carry many different designs in stock, ranging in prices from 10c to $\$ 2.50$ each. (See description below).

\section{Prices on Aquarium Castles}

(1) Lighthouse -5 in high. Each, 50c; $6 \frac{1}{2}$ in., $55 \mathrm{c}$ in., $\$ 1.00$.

(2) Single Ruin-7 in. Each, 40c; 12 in., 65c

Grotto with Bowl (not illustrated)-15 in. high; suitable for large aquarium. Each, \$2.50.

Many other elegant castles at low prices.

(5) Open Castle-4 in. high, 40c; 6 in. high, 60c; 8 in.

1.00. Gothic Arch-6 in. high. Each, 40c; 8 in. high, 75e

(7) Plain Arch-6 1 in high

(8) Botanic Areh-6 $\frac{1 / 2}{2}$ in. high. Each, 75c; $10 \frac{1}{2}$ in.

\$1.25. Round Grotto-3 in. high. Each, 15c; 4 in., $25 \mathrm{c}$

in., 45c.

Plain Rock (not illustrated) -2 in., 10c; 5 in., 15c; 4

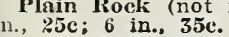

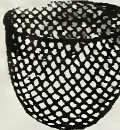

\section{$=$}

Dip Nets-For handling fish, 25c each, post paid.

Crushel Pearl Aquarium Shell-5c 1b.; 6 lbs., 25c. Pure White Sand-Desirable for putting in the bo of fish glohes and aquariums. Pkg., 10c; 2 for $15 \mathrm{c}$.

Aquarium Shells-A nice mi in bulk. 15c to 30c per pint.

Rubber Syphon-1/4-inch, 50c per yard.

\section{Bulbs for Fall Planting}

Send in your orders today so we can reserve the very hoicest bulbs for you and ship in proper season.

choicest bulbs for you
WE SHIP SEPTEMBER 1 TO NOVEMBER 1 .
Prices oll bulbs by mail, express or freight, prepaid.

\section{Chinese Sacred Lilies}

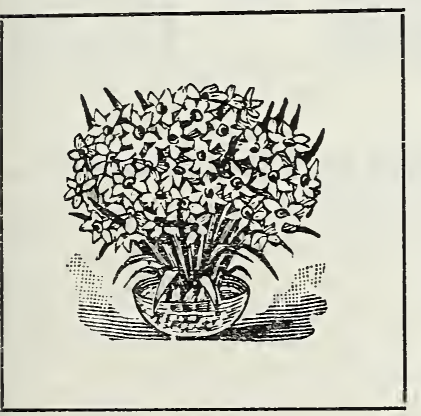

The most easily grown and satisfactory bulb for house or window eulture Fancy bulbs, each, $15 \mathrm{c} ; 2$ for $25 \mathrm{c}$.

\section{Jonquils}

Highly prized for their graceful, fragrant yellow blossoms.

$S$ in $\mathrm{g} l$ e $S$ w e e tScented-Doz., $35 \mathrm{c}$ $100, \$ 2.50$. $\underset{\text { Scented-Double }}{\text { S w e e t- }}$ $00, \$ 3.00$.

For a more complete list of BULBS for WINTER BLOOMING our Fall Bulb Catalog, with full descriptions of hyacinths, tulips, crocus, nareissus, lilies and all bulbs and seeds for fall planting will be is sued about August 15th. All lovers of flowers should have it. Iailed free to any address.

\section{Narcissus or Daffodil}

Selected bulbs for either garden or house culture. Double Von Sion-The well-known popular double yel low daffodil. Extra select bulbs. Each, 5e; doz., 50c

Empress-Giant, single yellow trumpet, rich color. Each, 4c; doz, 40c; 100, \$2.75.

Emperor-Giant, single white trumpet. Each, 4c; doz. $40 \mathrm{c} ; 100, \$ 2.75$.

Peoticus or Pheasant's Eye-Single pure white, orange up. Each, 3e; doz., 20c; 100, 75c.

Peoticus Ornatus-Earlier. Each, 3c; doz., 25c; 100

\section{GIANT “PAPER WHITE” NARCISSUS}

These beautiful, graceful narcissus are the best of al the European bulbs for growing in winter growing in pots or pans. Extra selected bulbs, each, 6c loz., 60c; $100, \$ 3.50$.

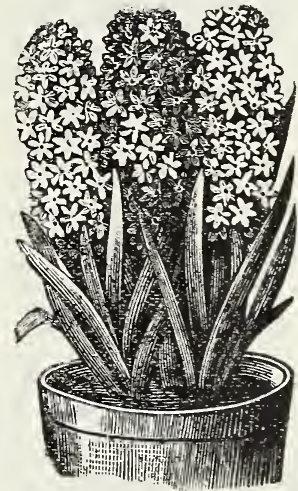

\section{Hyacinths}

Hyacinths, Double - F i n mixed; select colors, 7c each 70c doz.; $\$ 5.00$ per 100 .

Hyacinths, $\mathrm{S}$ in $\mathrm{g} \mathrm{le}-\mathrm{F}$ i $\mathrm{n}$ mixed; select colors zc each; 75c doz.; $\$ 5.00$ per 100 .

Hyacinths, French RomanThe earliest bloomers of all the hyacinths. Fragrant white flowers. 8c each: $75 \mathrm{c}$ doz: $\$ 6.00$ per 100 .

\section{Tulips}

Tulips, Single Early-Superfine mixed; a splendid assortment. 4c each; 35c doz.; $\$ 2.50$ per 100.

Tulips, Double Early-Fancy ors. 4c each; $35 \mathrm{c}$ doz.; $\$ 2.50$ per 100 .

Tulips, Late or May Flowering-For out-door planting only.

Bizarres-Yellow ground, feathered crimson, purple or White. 4c eac Bybloems - Brilliantly variegated, white ground, flaked lilac purple 4e each; 35c doz., \$2.25 per

Darwin Tulips - Named varieties. $45 \mathrm{c}$ doz., 25 for $\$ 1.00 ; 100$ for $\$ 3.00$.

Darwin Tulips-In splendid mixture. 40e doz., 25 for $75 \mathrm{c} ; 100$ for $\$ 2.50$.

\section{Christmas Greens}

Holly Bouquet, Green Mistletoes, Holly wreaths, Christmas Trees, Wild Smilax, Needle Pines, Cape Flowers, Pampas Plumes, Candes

Write for price list issued December 1st of each year.

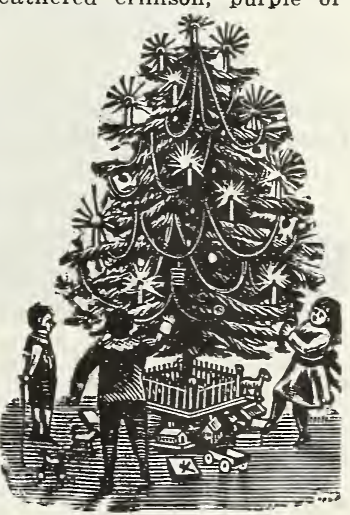

\section{Don't Forget Your Friends}

in distant cities. Through the Telegraph Delivery Association we can deliver flowers in any city in the country at about the same prices as quoted here, and guarantee satisfaction.

You take no risk in ordering, as we assume that. There is no extra expense unless we have to telegraph the rder. This arrangement is good any time, anywhere.

We own the largest and finest system of greenhouses in central Missouri, and make a specialty of growing cut flowers at all seasons of the year.

Elegant designs, up-to-date ideas, executed on short notice at moderate prices.

Telephone or telegraph your orders, mention time goods must reach you, and give references.

We ship C. O. D. to unknown customers.

Flowers and designs in any form ean be packed so they will travel perfectly by express at any time of the year We make no charge for packing.

Always state amount you wish to pay, and we will send as large and handsome pieces as we can for the price. If undecided we will make selection for you.

Consultation or correspondence on style of table decoration, bouquet or design is freely invited. We are replete

$n$ ideas and suggestions, and are pleased to answer any inquiries.

Large, elegantly illustrated catalogue of cut flowers, decorations, floral designs and bouquets printed from photographs on heavy enamel paper will be mailed to any adaress for $25 \mathrm{c}$, which may be deducted from the first order. 


\section{Archias' Poultry Keepers' Supply Department}

Is the largest in the West. Here you find everything from a leg band to an incubator. We handle only the very best, and at reasonable prices. Only supplies of known merit are here offered to our customers, and our guarantee goes

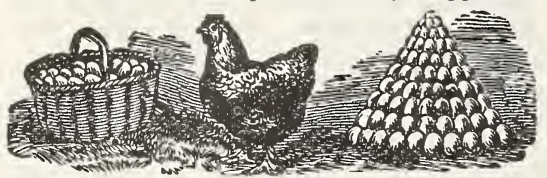
with every article sold-honest goods and honest prices. This method ( and is gaining for us thousands of new friends each year.

Our termis are Cash with order. We ship promptly. We guarantee safe arrival. We get you the lowest express and freight rates. We own the OLDEST ANI BEST KNOWN SUPPLY HOUSE IN THE
WEST.

Combine your orders for supplies with your Seed orders and save freight.

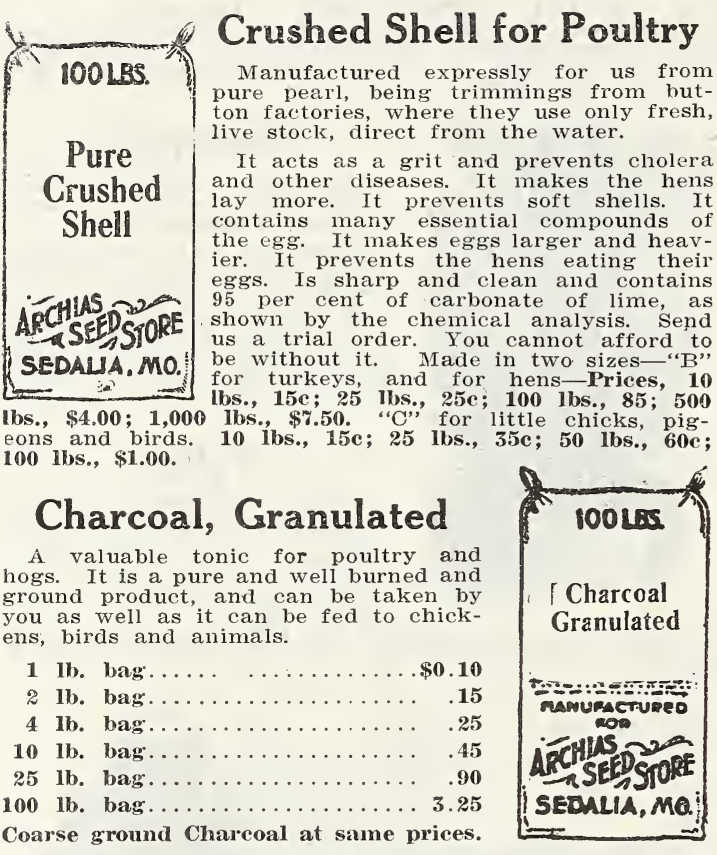

\section{Champion Leg Bands}
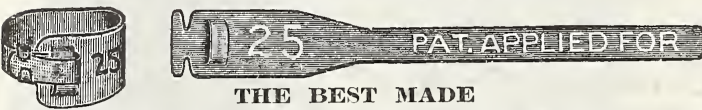

\section{THE BEST MADE}

In Four Sizes-4, 3, $21 / 2$ and $2 \frac{1}{4}$ inches long.

Made of best quality aluminum. One dozen for 15c; 25 for $25 \mathrm{c} ; 50 \mathrm{c}$ for $40 \mathrm{c} ; 100$ for $75 \mathrm{c} ; 250$ for $\$ 1.75 ; 500$ for $\$ 3.75$, prepaid. In ordering bands state size wanted.

\section{Climax Leg Bands}

\section{Sizes Used for Different Breeds}

No. $1-\mathrm{M}$ e d i t e rranean feMediterranean

No. 2-M e d i terranean ifemales.

No. 3-Meditarranean males and American females.

No. 4-I,arge American females, small American males and small Asiatic females.

No. 5-American $\mathrm{m}$ a l e s, Asiatic females, small Asiatic males

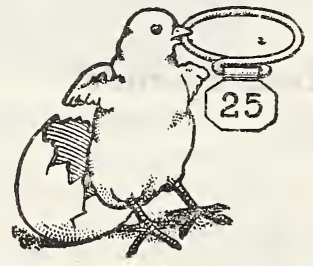

No. 6-Asiatic males and turkeys.

Dozen, 15c; 25 for 25c; 50 pensive at any price. Our bands are the best made.

Loft foot $\in \in \in \in \in \in \in \in \in \in \in \in$

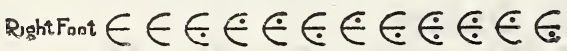
12 Examples for Marking Chicks

\section{Mica Crystal Grit}

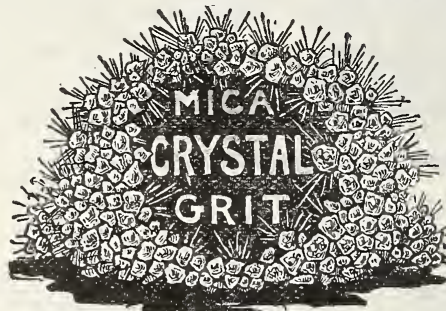

Our "Sure" Brand the best and only Grit for Poultry and Pigeons.

10 lbs.......\$0.15

25 lbs....... .25

300 los...........

500 Ibs...... 3.75

Mixed Shell, Bone Ieal and Mica Grit tion, 10 los proporlbs., 30c: 100 ibs. $\$ 1.00 ; 500$ lbs., \$4.50.

Chick and Bird Grit or Manna-Ground fine. Just the thing for small chicks, pigeons and pet birds. 5 lbs.,

\section{CRYSCO-CO \\ Grit and Shell Producer}

A shell producer and grit in one. It is the crystalized molluscan shell formatnon or petrified shell, nature's own product, and is mined and crushed coarse. 5 lbs.. 10c; 10 lbs., 15c; 25 lbs. 25c; 50 lbs., $45 \mathrm{c}$; 100 los., 85c.

Pure crushed oyster shell.

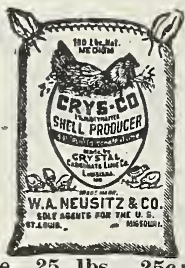
Pedium size, 25 lbs., 25c. 100 Ibs., 75c; chick size, 25 lbs., 35c; 100 Ibs., $\$ 1.00 ; 500$

\section{Aluminum Pigeon and Bantam Bands}

Made open or solid, as shown in cuts. In ordering bands state size and style wanted. Dozen, 20c; 25 for

Pigeon bands made from alum-
inum are put on safely when birds
are young. They are very light,
and the two styles offered above
are the best on the market. It
pays to band your pigeons to pre-
vent them from getting mixed
with your neighbor's birds.

\section{Smith Sealed Leg Bands}

Prices, prepaid by mail or express; 12 for 30c; 25 for $50 \mathrm{c} ; 60$ for $\$ 1.00$; 100 for $\$ 1.50 ; 250$ for $\$ 3.50 ; 500$ for $\$ 6.50 ; 1,000$ for $\$ 12.50$.
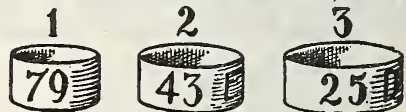

\section{Philadelphia Poultry Marker}

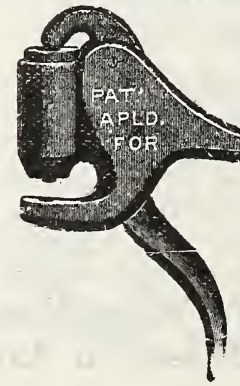

Like cut, and made in two larger for marking large fowls. Price, 25c, postpaid.

\section{Archias' Reliable} Spring Lever Poultry Marker

This is one of the best and most popular makes on the market, and will give satisfaction. Each, 25c, ostpaid.

Davis' Chick Marker-Reversible and cuts 2 sizes. Price, 25c; 3 for $60 c$, pestpaid. 
A R C I A S ' SEED STORE, SEDALIA, MISSOURI

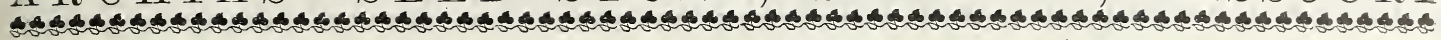

\section{Archias' Poultry Keepers' Department}

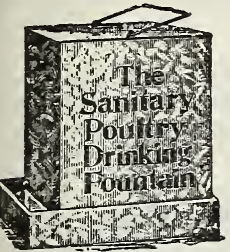

The "Triumph" Caponizing Set

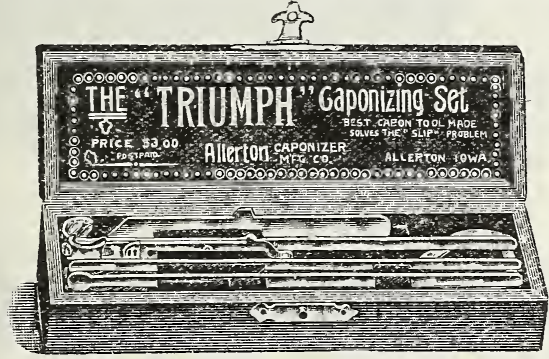

Complete Triumph set, postpaid............... \$2.75 Complete Set, in polished hardwood box Complete Set in cloth covered, plush lined case

\section{Pilling's}

Caponizing Instruments

With full instructions for using and caring for Capons.

Price for Complete In velvet case, $\$ 3.00$.

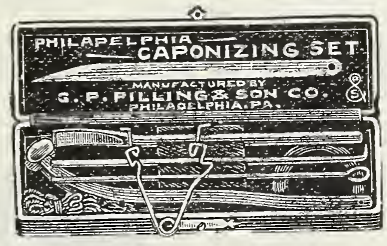

\section{Atsatt's Chick} Feeder

"They cannot get into it.

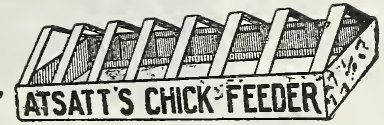

Therefore clean food. for cleaning. Sack into place. Be used for either wet or dry feed or for water. Cannot rust. Made for any brooder, but does not take up much suace. Made for any brooder, but does not take up thing for your brooder. Price, 30c; by mail, 40c.

\section{Chinese Nest Egg}

Best made; last forever. Worth ten times their cost the first season. 4c each; 6 for $20 \mathrm{c}$; $30 \mathrm{c}$ dozen; 4 dozen, \$1.00. Packing free.

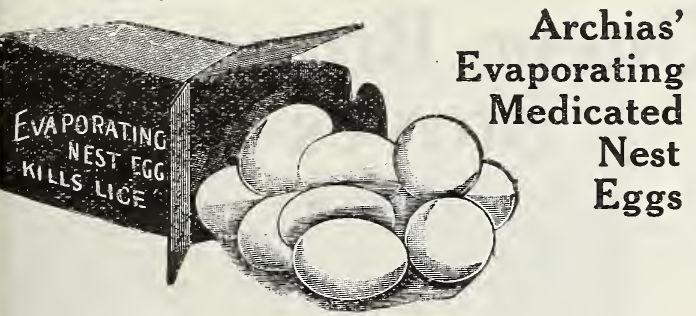

Will not lost their strength. Positively not injurious to hens, but should be removed from under setting hens. They answer the double purpose of nest egg and insecti-

Guaranteed to keep both nests and hens free from lice. Only 60c per doz.; 2 doz., $\$ 1.00 ; 5$ doz., $\$ 2.25$; order at

Archias' Automatic Feeder

It feeds water, grain, grit, oyster shells, etc., and is the most Sanitary Fountain on the market; you can always see just how much water it contains witbglass jar fits it. We do not furnish the jars. Each, 15c; 3 for 40 ; 6 for $75 \mathrm{c}$; dozen, $\$ 1.40$, postpaid.

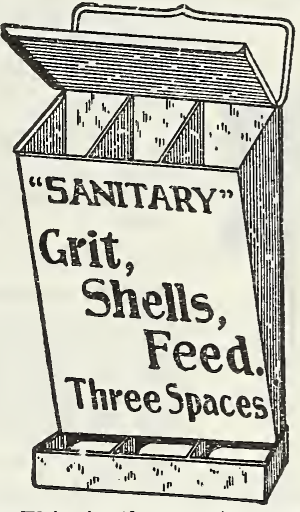

This is the most convenient and successful nest made. It mites and lice away; lasts for-

Price, each, 15c; 2 for $25 \mathrm{c} ; 1$ dozen, $\$ 1.25$.

The Reliable Lice Killing Machine

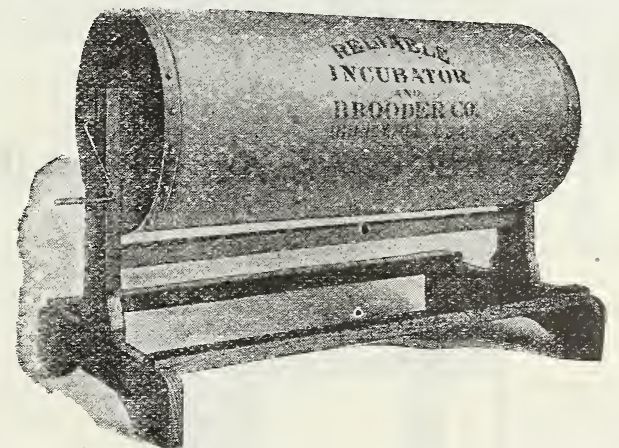

Will clean lice from poultry, pigeons, turkeys, geese, ducks, cage birds or anything that wears feathers. A No. 1-Made for little chicks and mother.

The No. 2 standard size, used by poultrymen in general is for all sizes of chicks and fowls. This size will hold 100 chicks, or 12 fowls at a time.

No. 3-Made for turkeys and geese.

Prices, with sizes and weights are as follows:
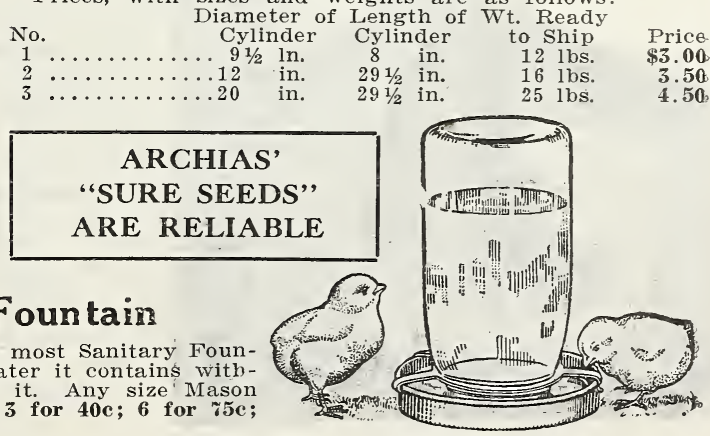


\section{Queen Incubators}

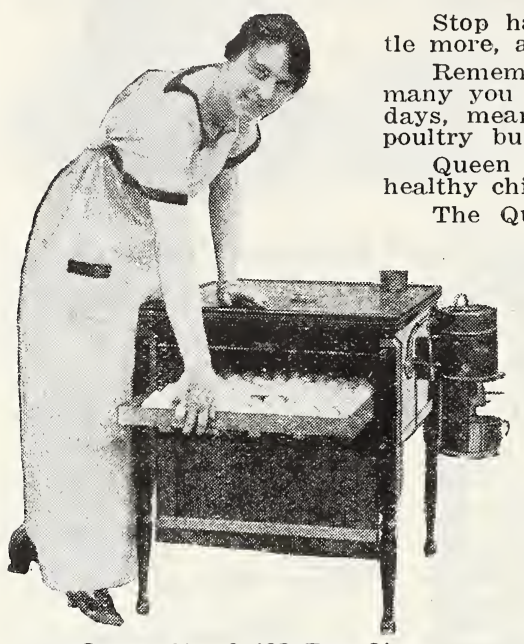

Queen No. 2 135-Egg Size

hatching weak chicks with cheap incubators. A Queen costs but lit-

and the extra chicks that live and grow soon pay the difference. Remember, it is not how many chicks you hatch that counts, but how
many you raise. Chicks that hatch out weak and wobbly, and live but a few days, mean nothing to you but trouble and loss. They make one sick of the

Queen Incubators are famous the country over for big hatches of strong,

Queen is double insulated.

The Queen System of hot water heating prevents the drying-out tendencies found in hot air incubator's and provides a soft, uniform heat over every part of the egg-chamber-a heat that is most natural for the hatching of eggs.

Both Queen Walls are built of genuine California Redwood, which is unusual in these days of imitation and cheap substitution. Redwood does not absorb the odor from the hatching eggs. /Cheaper woods, and pasteboard lining in iron and tin machines, retain the odors, to weaken and kill the hatching chicks.

\section{SIZES AND PRICES}

No. 0 - 60 egg size.......................... $\$ 10.50$

No. 1 - $85 \mathrm{egg}$ size....................................... 17.50

No. 2-135 egg size.

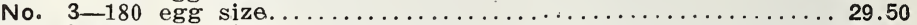

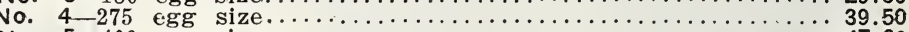

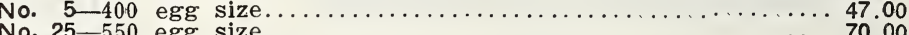

No. $25-550$ egg size............................... 70.00

\section{Queen Brooders}

Queen Outdoor Lamp-Heated Brooders are designed to raise the chicks in all kinds of weather at any time of the year, with complete protection day and night.

They are made of 1 -inch, high-grade thoroughly seasoned hardwood lumber with mortised corners, bound with galvanized iron and covered with two coats of paint.

125 chick size.................................. $\$ 24 \cdot 50$

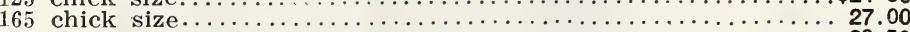

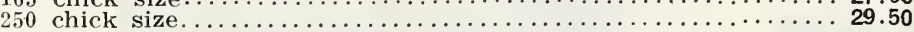

\section{Queen Indoor Lamp Heated Brooder}

No. 7-125 chick size, shipping weight 65 lbs............\$16.00

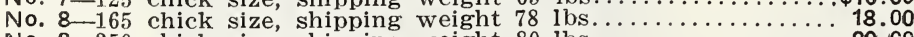

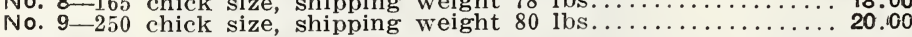
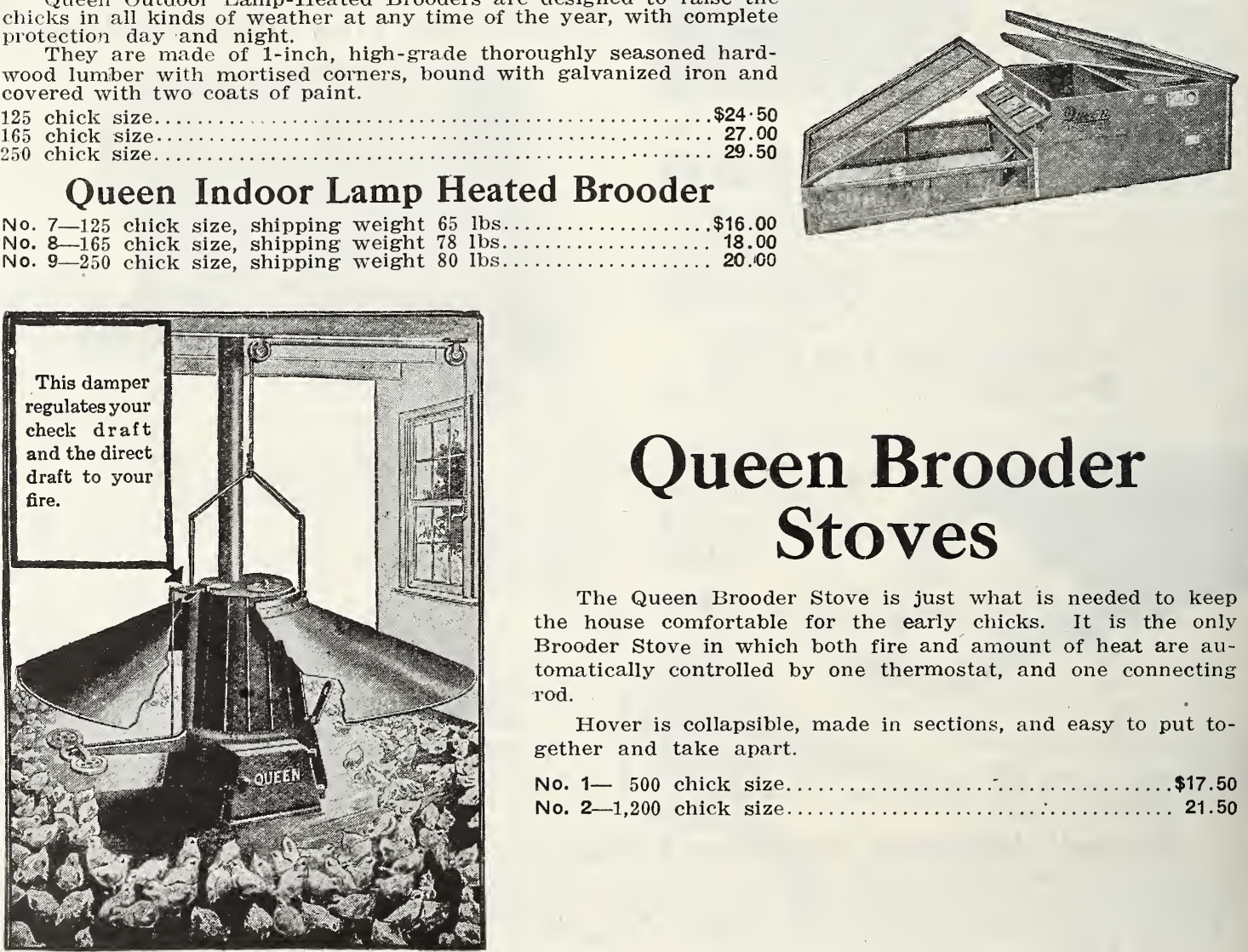

\section{Queen Brooder Stoves}

The Queen Brooder Stove is just what is needed to keep the house comfortable for the early chicks. It is the only Brooder Stove in which both fire and amount of heat are automatically controlled by one thermostat, and one connecting rod.

Hover is collapsible, made in sections, and easy to put together and take apart.

No. 1- 500 chick size........................ $\$ 17.50$

No. $2-1,200$ chick size............................ 21.50 
A R C I A S , SEED STORE, SEDALIA, MISSOURI

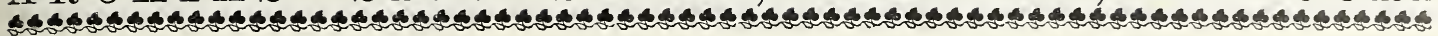

\section{$\overline{\text { GENUINE }}$ Standard Cyphers Incubators $\overline{\text { PATENTED }}$}

We offer our customers the Cyphers Company's complete line of incubators and brooders. EVERY STAND. ARD CYPHERS INCUBATOR IS GUARANTEED by the manufacturers to do first-class work, and we hereby place our guarantee back of theirs. In buying a Cyphers you take no chances.

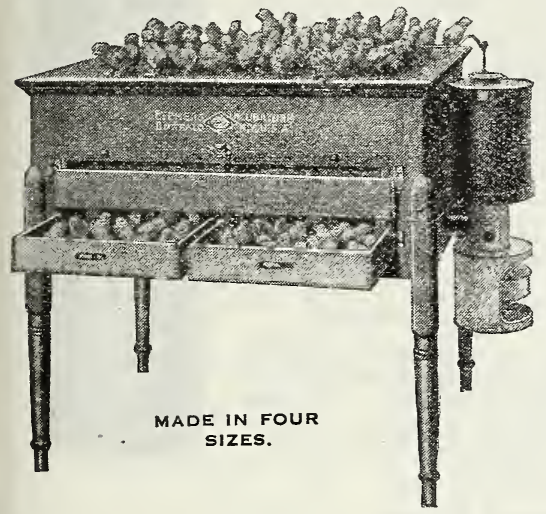

SIZES AND PRICES OF CYPHERS INCUBATORS-FREIGHT No. 0 holds 70 hen eggs. $\$ 16.00$ No. 2 holds 244 hen eggs. $\$ 37.00$ No. 1 holds 144 hen eggs. 25.00 No. 3 holds 390 hen eggs. 44.00

\section{Cycle Hatchers,}

\section{Holds 50 Eggs}

Constructed entirely of metal; selfregulating; requires no moisture; will not warp, shrink or crack; will last a lifetime. Hatches hen, duck, gees and turkey eggs equally well. $\$ 7.50$.

\section{Brooder-Hatcher Holds 50 Eggs}

A compact, safe and practicable incubator and brooder combined, one lamp serving both purposes. Saves about one-half the cost of hatching and brooding chicks. $\$ 9.50$.

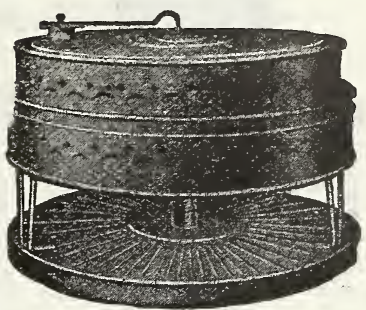

\section{"OLD TRUSTY" INCUBATORS and BROODERS}

We have the agency for Mr. Johnson's machines and sell them at factory prices. We prepay the freight, ship promptly, and guarantee every machine to be as represented. Best material and construction of case the best non-conducting walls, lid and bottom ever put in incubator construction. Not a particle of wood exposed; even the legs are built of heavy metal. The asbestos insulation and the redwood inner case completes the ideal. Convenient thermometer holder simplicity of regulator-a single adjusting nut sets the regulator, the set nut outside of incubator, and when once adjusted it stays right and governs the heat to a fraction of one degree. Everything so simple that a child can make big hatches.

100 (120) Egg Old Trusty Incubator, with all tools and fix-

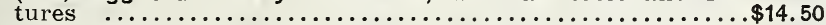

150 (175) Egg old Trusty incubator, with all tools and fix-

200 (240) Egg oid Trusty incubator, with all tools and fix-

100 Chick oid Trusty Brooder, with all tools and fixtures..... 8.00

150 Chick Old Trusty Brooder, with all tool and fixtures..... 9.00

200 Chick Oid Trusty Brooder, with all tools and fixtures....10.00

When incubators and brooders are ordered together the price for both will be as follows:

120 Egg Incubator and 100 Chick Brooder..............\$22.50

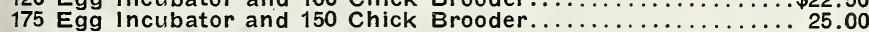

240 Egg Incubator and 200 Chick Brooder................ 29.00

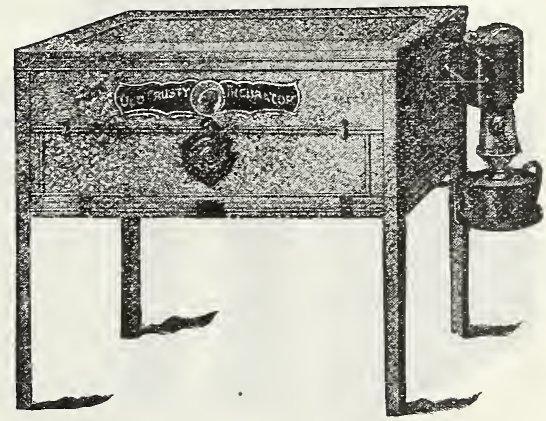

THE “IDEAL" GRAIN SPROUTER AND SANITARY HOVER

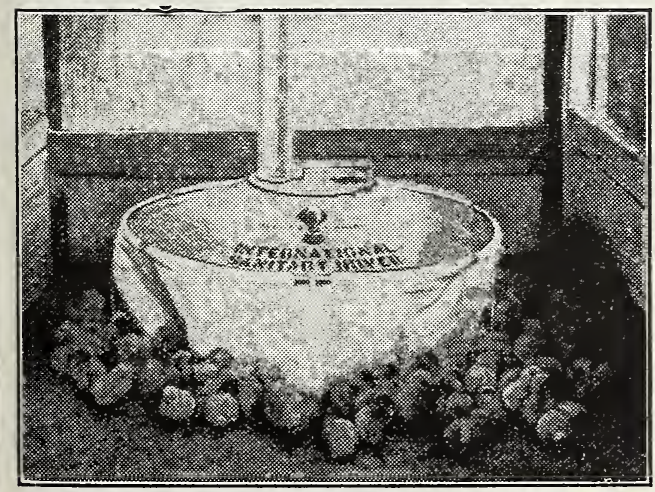

IMPORTANT TO REMEMBER

That quickly sprouted oats make the best of green food for chickens.

That 12 quarts of oats can be sprouted at one time under the International Sanitary Hover

That 12 quarts of oats sprouted under the International Sanitary Hover will yield in eight days enough green food to feed 500 laying hens for three days.

That letting the sprouts grow for eight days doubles the yield of green food over the yield for the sixth day.

That instead of having to store his hovers during the fall and winter months the user of Sanitary Hovers can work them the year around-as brooders in brooding time, as oat sprouter's when other hovers are idle.

That oats must be soaked over night in lukewarm water before being placed under the hover.

That the curtain must positively be left on the hover during the first three days to hold the heat about the oats.

That the Sanitary Hover, considered merely as an oat sprouter, will pay for itself many times over.

Scores of customers, after brooding for a season with the Sanitary Hover, have written to us that they would not sell it at any price if they could not repeat on orders. Every machine fully warranted.

Our Price for Ideal Oat Sprouter and Sanitary Hover Combined, $\$ 10.00$. 


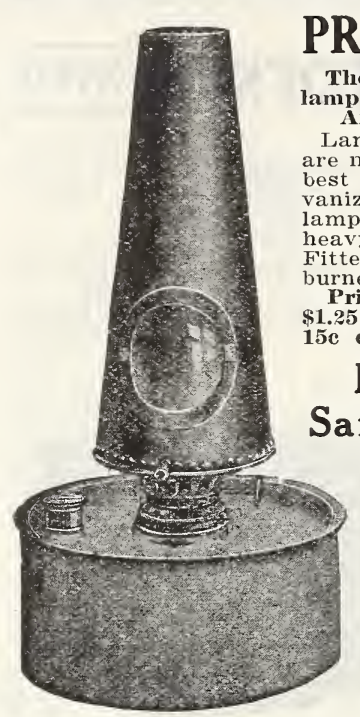

Miller Lamp

\section{PRICE LIST OF INCUBATOR and BROODER SUPPLIES}

The zero safety mp for Incubators And Brooders.

Lamp and Chimney are made of the very best quality of galanized iron, and the amp is fitted with a eavy brass burner. itted with No. 2 rner only.

rice of the zero is 25 each. By mail,

\section{Miller's}

\section{Safety Lamp}

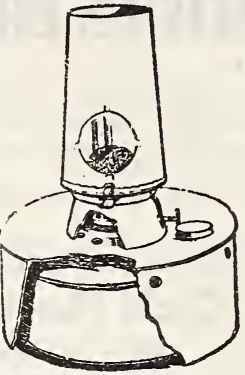

For Incubators and Brooders. Complete with burner and flue. When ordering lamps, be sure and give us the size of your incubators and brooders. Price: No. 2, $\$ 1.75$; No. 3, $\$ 2.00$.

Lamp Wicks-Any size, each, 5e; 3 for 10c; doz., 25c. In ordering wicks mention size wanted.

Lamp Burners-Nos, 1 and 2 , 50c; No. 3, each, 65c.

Metallic Lamp Chimneys, 35c each.

Connecting rod and burrs, 20c each.
(Extra burrs for rods cannot be furnished.)

Dampers, any size or style. Postpaid ...............40c Filler caps and nozzle. postFiller caps and nozzle. postFunnels, postpaid ..... . . Isinglass for lamp flues, any
size, postpaid ........... 15c

TAYLOR BROTHERS' HIGH GRADE TESTED Thermometers

Guaranteed Accurate.

Incubator ThermometersThe best for Queen, Sure Hatch, Old Trusty, Cyphers and other incubators. Each, 85e postpaid.

Brooding . Thermometers Each, 35c, postpaid.

Erg Testers-Best made; all metal; 35c each, postpaid.

Insect Bellows for dusting fowls, etc 10c each, postpaid Oaks' Double Wafer (for incubator regulators), each, $\mathbf{7 5 c}$, postpaid.

Incubator Regulator - Complete with wafer and bracket, only $\$ 2.50$.

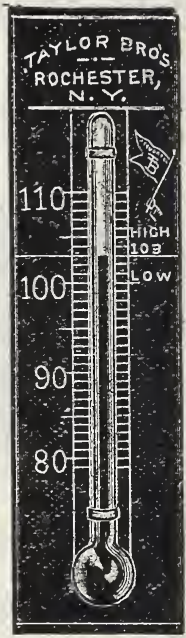

\section{The Up-to-Date Sanitary Brood Coop}

For successful chicken raising it is necessary to protect the young brood from rats, cats, mink, weasel and other pests This no bugs or insects of any kind can live in it: has ventilated top and end Our top ventilation gives a circulation of air through the coop and keeps it from getting hot on the inside. It has three doors, one wire screen door, one slatted

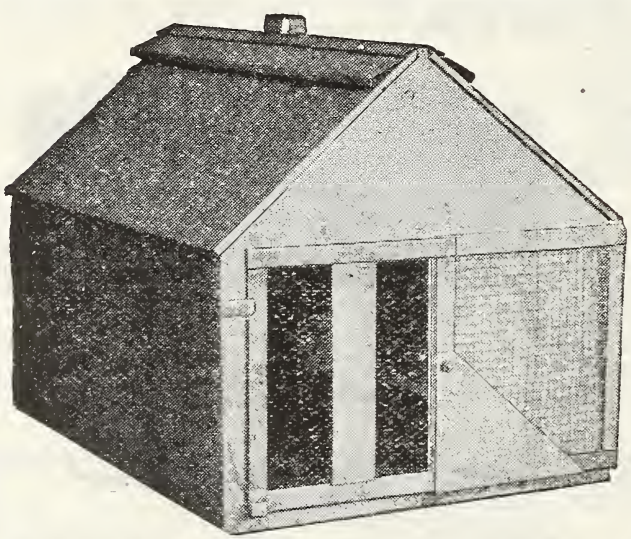
door to allow the little chicks to pass in and out and door to close in case of rain. They work in a pivot and cannot be forced open by the old hen. They are shipped knocked down and will go as fourth-class freight. Size about 18 inches high, 18 inches wide and 24 inches long. Our price, each, \$2.50; 6 for $\$ 14.00$.

\section{Trap Nests}

We have two of the best makes of trap nests. Catalogue and prices on application.

\section{Archias' "Sure" Exhibition Coops}

A thoroughly satisfactory exhibition coop that embodies the qualities of durability, neatness and practicability, has been much in demand. We believe that we have solved the problem in the construction of the Sure Exhibition coop. The framework is construction of the Sure Exhation cop. The hanes. The rods in front do not obstruct the view like wire. It has a door sliding up and down. Single coop measures 2 feet wide, 2 feet deep and $2 \frac{1}{2}$ feet high. Double coop measures $3 \frac{1}{2}$ feet wide, 2

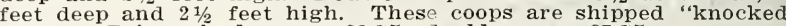
down." Price, single coop, $\$ 2.75$; double coop, $\$ 3.75$.

\section{Eyrie Corrugated Paper Shipping Coops}

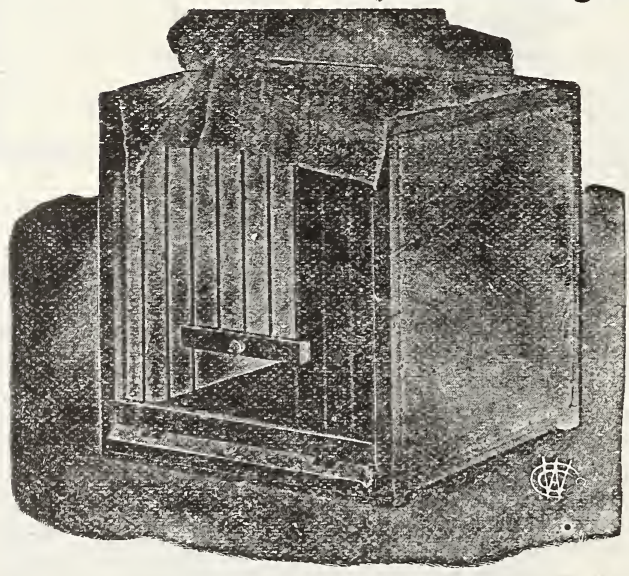

The strength of the Eyrie Coop is such that it will bear any amount of weight and is perfectly safe, having been accepted by the express companies on the same basis as the wooden coop. Made in four sizes, for single birds, pairs, trios and breeding pens.

\section{Price of Ship- ping Coops}

A- $12 \times 16 \times 18$ in, 50 c each: 3 for $\$ 1.40$; doz., $\$ 5.50$.

$\mathrm{B}-12 \times 18 \times 22$ in., $60 \mathrm{c}$ each: 3 for $\$ 1.50 ;$ doz., $\$ 6.00$.

C- $12 \times 22 \times 22$ in.. $75 \mathrm{e}$ each: 3 for $\$ 2.00$; doz., $\$ 6.50$.

D- $20 \times 22 \times 22$ in., $85 \mathrm{c}$ each: 3 for $\$ 2.25$; doz., $\$ 9.00$.

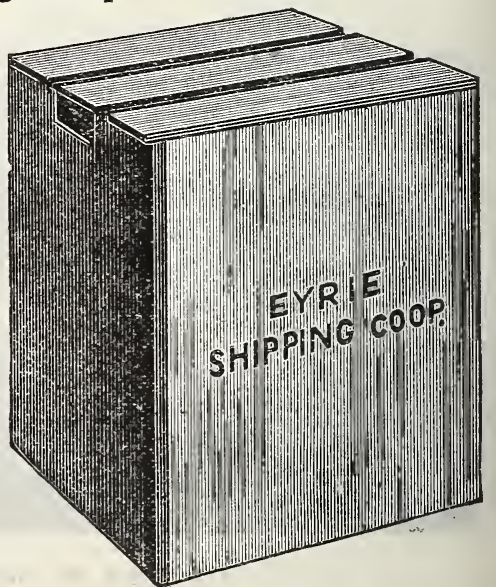


A R C I A S, SEED STORE, SEDA L A, MISSOURI

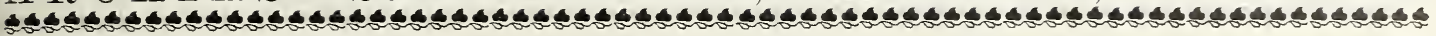
Archias' "Sure" Chick Feed A MOST COMPLETE AND POPULAR FEED THAT IS GUARANTEED

This is beyond any doubt the best Chick Feed on. the market. We say best because we know it. We spare no expense in procuring the best materials that enter into the etc, in proper proportions. Highly endorsed by all leading poultrymen. Once you use it you will have no other. We are selling tons of it. Best known food for little chicks. It will prevent and cure bowel complaint, a disorder that destroys more little chicks than all other causes.

It will make your little chicks grow faster than any other known preparation. It is fed dry Try bag. 25 lbs. \$1.25; 100 lbs., $\$ 4.50 ; 200$ lbs., \$8.75. Sacked free. Write for prices in larger quantities. Your money back if not pleased.

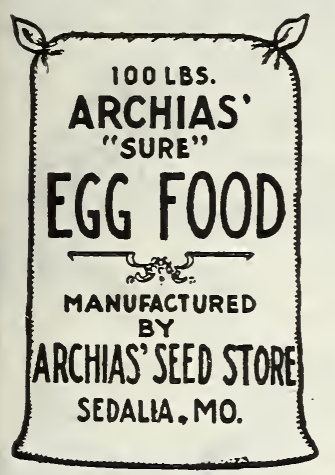

\section{Archias' "Sure" Egg Food}

A COMPLETE MASH FOOD SPECIALLY PRE-

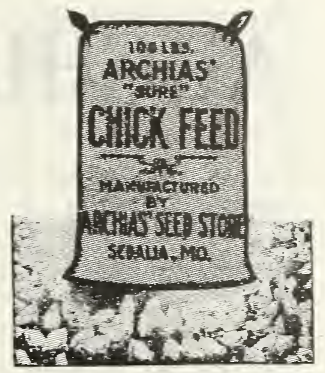
Strong in albumen and egg making properties. ter. mis is a ground feed to be mixed with warm water and only as much fed in the morning as will be eaten up clean in five minutes. You may mix a little corn meal or your table scraps if you wish. If fed according to directions will not fail to give perfect satisfaction. No feed in existence equals it to make hens lay. Specially valuable for winter feeding. Feed Archias" "Sure" Hen Feed in straw or litter in connection witı Archias" "Sure Egg Food" for best results.

\section{LESS FEED AND MORE EGGS}

Archias' "Sure" Egg Food is guaranteed to feed further than similar preparations on the market, and if fed according to directions will give you an abundance of eggs all tle year around. The largest poultry raisers recommend it. It is being fed daily to thousands of poultry. Eggs are high in price, and every, poultry raiser should be interested in getting more eggs at less cost., Archias" "Sure" Egg Food will do it. Order a bag at once. Save your grain. Archias' Egg Food is cheap to feed, and we get you the lowest freight rates. 25 lb. bag, $\$ 1.25 ; 501 b$. bag, $\$ 2.50 ; 1001 b .6 a g, \$ 4.50 ; 20010$. bag, \$8.50. It is all feed and no waste. The materials in this food take the place of green food, bugs, worms, and make hens lay all the year around.

\section{Archias' "Sure" Hen Feed}

A DRY MIXTURE OF SCRATCH FEED, PROPERLY PROPORTIONE D

This preparation is coarser than our "Sure" Chick Feed and intended to make young poultry grow fast. It is a complete feed that will give perfect satisfaction.

It takes the place of worms, insects, green feed and grain. No waste, no sickly hens, no soft shells, no want of eggs, if you feed our "Sure Hen Feed. Like all our other preparations, Archias' Sure Hen Feed is fully guaranteed to give satisfaction or money refunded. Bu., \$2.25; 2 bu., \$1.25; 5 bu., \$11.00. Sacked free.

\section{Archias' Pigeon Feed}

A scientifically prepared balanced ration feed. Especially adapted to the growth of voung pigeons and squabs. Mixed with cracked corn, wheat and field peas. Makes the best general feed for all kinds of fancy and domestic pigeons. Keeps the birds healthy and develops shape, style and plumage to a remarkable degree. As a foundation food it has no equal. 10 lbs., 85e; 25 lbs., \$1.75; 100 lbs., \$5.00.

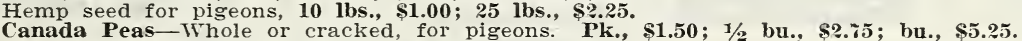

Wheat for Pigeons-Ask for prices.

\section{Eyrie Egg Box}

Time savers: Weight savers: Excel in strength and appearance, take minimum express rate and are cheap. You can pack twenty of these boxes in the time it takes to pack one basket. It only takes about one-quarter the space of an ordinary basket.

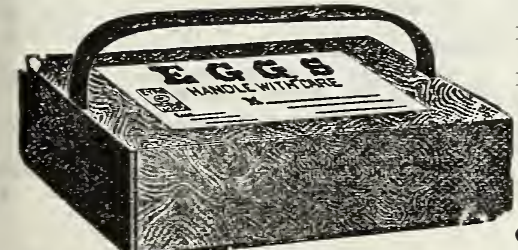
12 for 1200 .

No. 2-For two settings (30 eggs), 25e each; 12 for $\$ 3.00$.

No. 5-Holds 50 eggs. 35e each; 12 for $\$ 3.50$. Also 100-egg size, each $60 \mathrm{c}$; doz., $\$ 6.00$.

\section{The Reliable Egg Carrier}

Holds 12 dozen eggs. Each, 65c; 2 for \$1.25; 6 far $\$ 3.50$.

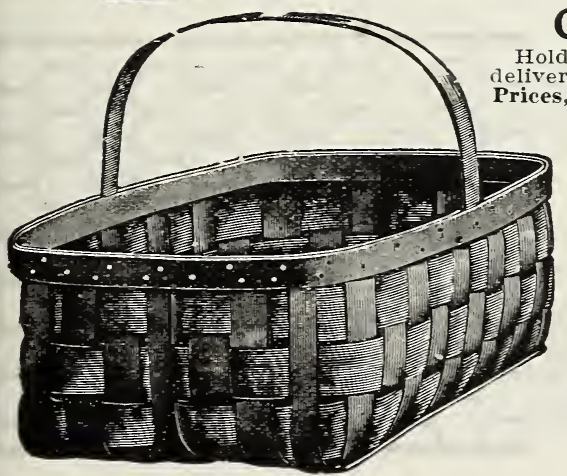

\section{Climax Paper Egg Boxes}

Holds 1 dozen eggs, and just the thing for
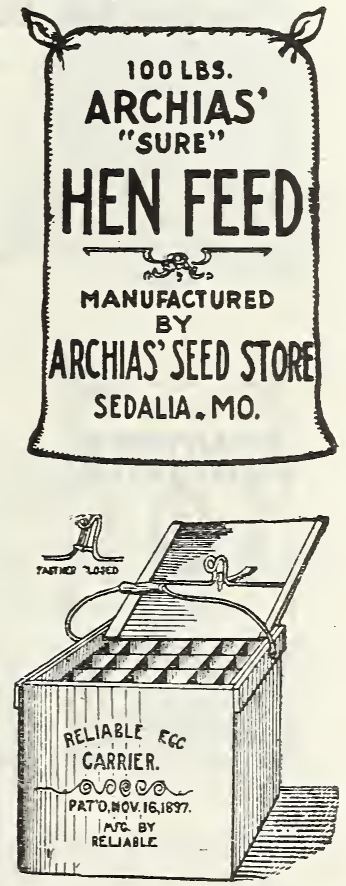

rices, 25 for $35 \mathrm{c} ; 50$ for $50 \mathrm{c} ; 100$ for $90 \mathrm{c} ; 500$ for $\$ 4.50$.

\section{Diamond Market Baskets}

Iade of good elm veneer, with strong handles. Excellent for shipping eggs, butter, dressed poultry, sausage, vegetables and other farm products. Made in two sizes:

No. 1 holds about one peck. Each, 10c, 4 for 30c, 12 for 75 c. No. 2 holds about $1 / 2$ bushel. Each 10c, 4 for 35̃e, 12 for 85 c. 


\section{ARCHIAS' ROUP GURE "sIMPLE and ALWAYYS SURE"}

\section{Roup, Its Causes and Symptoms}

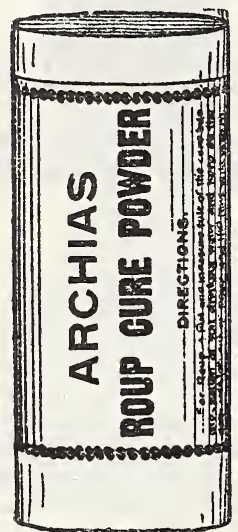

\section{Granulated Bone}

Is about the size of wheat and an be fed like any other food in grain about one handful for every ive fowls daily, or every other day. In either manner it furnishes a valuable food for poultry at all seasons of the year. Price, 10 lbs., $\$ 1.00$; 25 lbs., \$2.25; 50 lbs., \$4.25; 100 lbs., $\$ 8.00$.

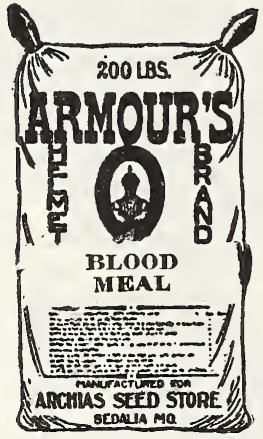

The primary cause is cold contracted either by draught of wind while at roost or exposure 作 canker, expecially in pigeons, this remedy excels all others, One If thise makes 25 gallons of medicine. Directions with every package. small size, 60c; large size, $\$ 1.20$.

\section{Conkey's Roup Cure}

An old well-known Roup Cure that is guaranteed. Large pka.. ; small size, $60 \mathrm{c}$, postpaid.

Poultry Diseases and Remedies

\section{Conkey's Remedies}

Conkey's Cholera Remedy-Pkgs., 30c and 60c, postpaid.

Conkey's Gape Remedy-Price, 50c; 65c, postpaid.

Conkey's Chicken Pox Remedy-Price, 60c; 65c, postpaid.

Conkey's Limber Neck Remedy-Price, 60c; 65c, postpaid.

Conkey's Scaly Leg Remedy-Price, 60c; 65c postpaid.

Conkey's Lice Liquid-1 qt., 50c; 2 qts., 75c; 1 gal., \$1.25; 5 gal.,

\$5.50; Cxkey's Head Lice Ointment-Kills the gnat head lose. It is harmless to chicks. Price, 10c and 25c. Both sizes postpaid.

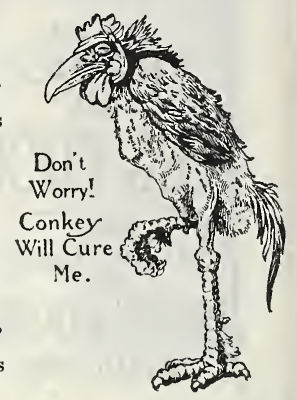

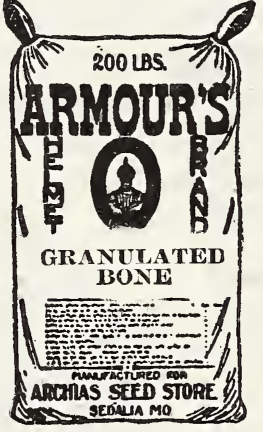

Bone Meal, Fine

\section{Ground}

For poultry. Fresh and pure; will not spoil. Should be mixed with feed. Price, the same as for granulated bone.

\section{Blood Meal}

Free from acids and chemicals. Unexcelled for poultry uses, substitute for meat. One $1 \mathrm{~b}$. is equal to 10 pounds of fresh meat. 3 lbs., $35 \mathrm{c}$; 10 lbs., $\$ 1.00$; 25 lbs., \$2.25; 100 lbs., \$8.50.

\section{Meat and Bone For Poultry}

Guaranteed to Keep Properly Mixed 10-1b. bag............\$0.75 $25-1$ b. bag. ............

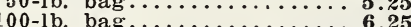

\section{Meat Meal}

10 -1b. bag..............\$0.75 25 -lb. bag. ............. 1.75

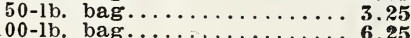

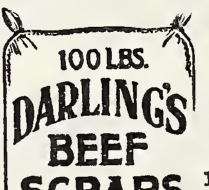

\section{Ground Beef Scraps}

10-lb. bag..................\$0.90 $25-1 b$, bag.................. $50-1 b$. bag.............................

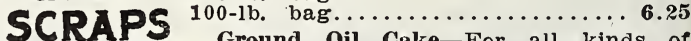
Ground Oil Cake-For all kinds of tock and poultry. 10 lbs., 45c; 25 lbs., $\$ 1.00 ; 100$ ibs., \$3.50.

MANUFACTUREO Sunflower Seed-For poultry. $10 \mathrm{lbs}$. ARCHIAS 20 $\$ 1.00 ; 25$ lbs., $\$ 2.25 ; 100$ lbs., $\$ 8.00$.

Cayenne Pepper-Ground fine. Lb. $60 \mathrm{c} ; 3$ lbs., $\$ 1.75$.

Pepper Seeds-Just the thing to $\mathrm{mix}$ in your mash feed, table scraps, etc. 1 Ib., 15c; 2 lbs., 25c; 10 lbs., \$1.00.

\section{Alfalfa Meal}

Green cured alfalfa ground into the finest meal. No adulterations; wonderful to make chickens grow and make hens lay in winter. $10-1$ b. bag...............\$0.50 50-1b. bag....

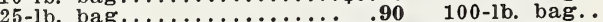
cut clover at a price in the reach Pitiver poultry and rice, $10 \mathrm{lb}$. bag, 50c; 25 lb. bag., 90c; 50 lb. bag, $\$ 1.50 ; 100$ lb. bag, $\$ 2.50$.

\section{Poultry Netting}

VERY BEST; HIGH GRADE AND WELL GALVANIZED

Price of 2-inch mesh, per roll of 150 feet in length:

1 ft wide.

$11 / 2$ ft. wide....................

ft. wide............ 3.00

ft. wide............... 4.00

ft. wide $\ldots \ldots \ldots \ldots \ldots \ldots, \mathbf{5} \cdot \mathbf{5 0}$

Netting Staples-Lb., 10c; 3 lbs.
Price of 1-inch mesh, per roll of

1 ft. wide.

$11 / 2$ ft. wide.

Special prices named on large orders; also made on different styles of netting or fencing.

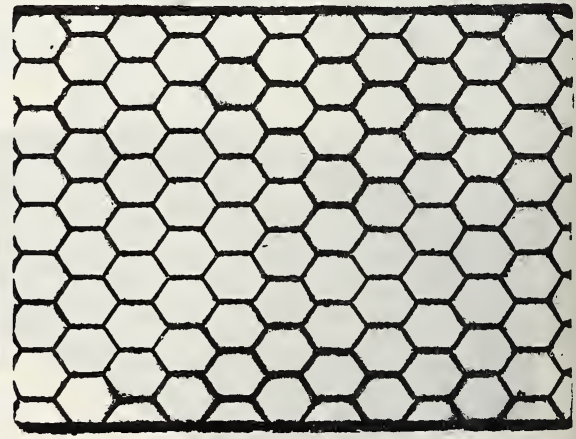


A R CHI A ' SEED STORE, SEDALIA, MISSOURI

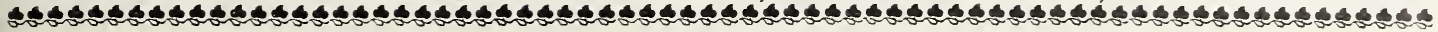

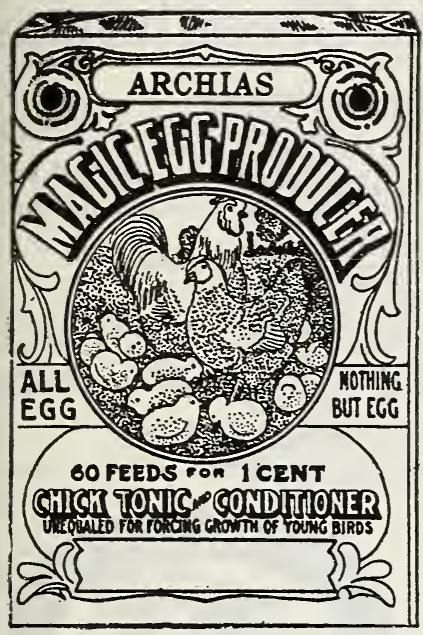

\section{Archias' Magic Egg Producer}

It supplies all meat food and other material neces sary for laying breeding stock and growing chicks except common grain, gravel or grit; composed of ducer. 21/2-1b. pkg., 25c; post paid, 35c.

\section{Archias' Worm Powder}

For Horses, Sheep and Hogs

Regularly used by thousands of stockmen. Worms are eradicated to a certainty and further at tacks are prevented. The powders act as a conditioner and regulate the bowels, restore the appetite and quickly put the animal in a healthy state. Results guaranteed or money refunded. Large package, $25 \mathrm{c}$; postpaid, $35 \mathrm{c}$.

\section{Archias' Microzone Tablets}

These are put up 25 in a box, and one box is equal to one bottle in strength. Easily dissolved in water. Price, 50c per box, postpaid. Full directions on each box.

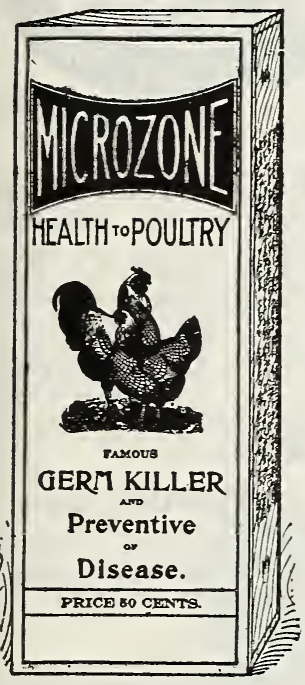

\section{Microzone}

Disease Cure and Preventive, Keeps Poultry in a Healthy Condition: A Valuable Antidote for Many Diseases of Live Stock.

Will cure Roup, Cholera, Indigestion, Bowel Complaints, Canker, Frosted Comb, Chicken Pox, Swelled Head, Sores, Cuts, Wounds, Sore Eyes, etc., etc. We strongly recommend its use occasionally, once or twice a week, in drinking water, which will prevent the possibility of disease invading the chicken house. Also cures Sore Mouth, Sore Breast, Back and Shoulders, Cracked Heels, Thrush, Wounds, Cuts, Sores, Saddle Galls.

Full directions on each bottle. Per bottle, 50c.

\section{International Poultry Food}

2,500 feeds for $50 \mathrm{c}$. Absolutely pure and highly concentrated. Will cure and prevent diseases of poultry. Will make your hens lay; will make your chicks grow fat. Directions on each package. Price 30c, 60c and $\$ 1.20$ per box.

\section{International Stock Food}

Fattens stock in 30 days' less time; saves corn or oats; increases the quantity of milk 15 to 25 per cent. Cures or prevents disease. Your money refunded in any case of failure.

\section{Guaranteed to Cure Hog Cholera}

Prices: Packages 30c, 60c and $\$ 1.20$; also 25-1b. pails, $\$ 3.75$ each. Special prices in larger quantities.

International Heave Cure-60c.

International Worm Powder-60c.

International Gall Cure-30c and 60c.

International Colic Cure-60c.

Pine Tar Healing Oil-50c and \$1.00.

Honey Tar Foot IRemedy-50c and $\$ 1.00$.

Security Gall Cure-30c, 60c and \$1.20.

Black Draught-For Poultry and Stock. Per pkg., 30c:

4 packages, $\$ 1.00$.

Security Poultry Food-A guaranteed poultry remedy for all diseases, highly recommended. Packages 30c, 60c

Security Worm Powder-Package 60c and \$1.20.

Security Stock Food-A highly indorsed preparation that is guaranteed. Package 25c, 50c and \$1.00.

\section{Cholerine}

A vegetable compound for Poultry; "death" to all diseases common to fowl. It will fatten them and put new life into them. It will bring you ten-fold more eggs and keep your flock healthy.

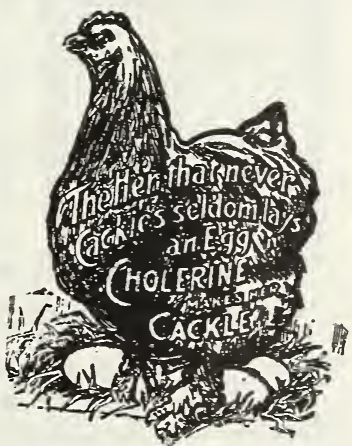

It makes the finest poultry food possible to buy; guaranteed to give perfect satisfaction and do all we claim for it or your money refunded. Price, 25c and 50e bottles; gal., \$2.50; 5 gals., \$9.00.

\section{Prates.}

Animal and Poultry Regulators and Veterinary Remedies

Pratt's White Diarrhoea Remedy in 25c and 50c pkgs. Pratt's Chicken Cholera Remedy, 25c and 50c pligs. Pratt's Sore Head Chicken Pox Remedy, 25e and 50e boxes.

Pratt's Poultry Regulator, pligs., 25c, 50c, \$1.00, \$1.25 and $\$ 2.50$.

Pratt's Animal Regulator, pkgs., 25c, 50c, 75c and $\$ 1.00$. Pratt's Condition Powder, pkgs., 25c, 50 and $\$ 1.00$.

Pratt's Hog Cholera Specific, pkgs., 50c; pails, $\$ 2.00$ and $\$ 3.50$.

Pratt's Cow Remedy, pkgs., 50c; pails, \$2.00 and \$3.50. Pratt's Distemper Cure, 60e bottle.

Pratt's Liquid Spavin Remedy, 60c bottle.

Pratt's Animal Dip, 50c, 90c and $\$ 1.50$ cans.

Pratt's Dog Biscuit, 15c 1b.; 3 lbs., 40c; 10 lbs., \$1.25;

25 lbs

Pratt's Head Lice Ointment, 25c box.

Pratt's Roup Remedies, pkg.

Pratt's Powdered Lice Killer, 25c and 50c pkgs.

Pratt's Liquid Lice Killer-40c, 70c and \$1.25 cans.

Pratt's Veterinary Colic Cure, 60e and \$1.25.

Pratt's Veterinary Healing Ointment (Gall Cure), 25e and $50 \mathrm{c}$ boxes.

Pratt's Veterinary Liniment, 25c, 50c and $\$ 1.00$ bottles.

Pratt's Specially Prepared Worm Powder, 50c pkg.

Pratt's Heave, Cough and Cold Remedy, 50c and $\$ 1.00$ pkgs.

PRATT'S Remedies Sold by Archias' Seed Store, Sedalia, Mo. 


\section{Insecticides for Orchard, Garden and Greenhouse}

\section{Arsenate of Lead}

Most effective poisonous in-

secticide for leaf-eating insects.

Will not scorch, burn nor injure the folilige, but kills all kinds of leaf-eating insects. Takes the place of
Paris green, London purple, arsenate, etc. Sticks to the foliage throughout the season; not affected by rains. $\$ 1.75 ; 10$ lbs., \$3.25; 50 lbs., $\$ 12.50 ; 100$ lbs., \$24.00.

\section{Standard Bordeaux Mixture} PASTE FORM

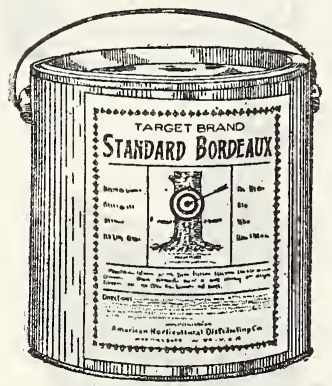

Is one of the cheapest and most reliable fungicide on the market. 1 lb. can, $45 \mathrm{c} ; 5$ 1b. can, $\$ 2.00 ; 10$ lb. can, $\$ 3.50$.

Lime Sulpluur Solution-A perfect scale and fungus destroyer; special for plum and peach trees, which need fall and spring treatment; cures peach leaf curl. Use during hands with gloves when applying. Dilute with 10 parts of water, apply with spray pump. 1 qt., 45c; 1 gal., 85e; 5 gals., $\$ 3.25 ; 10$ gals., $\$ 6.00$.

Tobacco Dust-Kills green and black lice, beetles, fleas, tc. Dust the plants with it. Lb., 10c; 10 lbs., $\mathbf{5 0}$; 25 lbs., \$1.50; 50 lbs., \$2.75; 100 lbs., \$5.25.

Paris Green-1/4 lb., 30c; 1b., \$1.00; 10 lbs., \$9.50.

Sulphate of Copper-Lb., 25c; 25 lbs., \$5.00.

Pure Persian Insect Powder-0z., 8c; 1/4 1b., 30c; lb., $\$ 1.00 ; 3$ lbs., \$2.75.

\section{Germo Insecticide}

The great disinfectant, germ and insect killer. Will not stain. Small bottle, $\widetilde{F 5 c}$; large bottle, 50c; 1 gal. jug,
$\$ 2.50$.

\section{Archias' "Sure" Liquid Lice Killer}

Sure death to all vermin on Poultry, Hogs, Cattle, Sheep, etc. Claimed the best and strongest Insecticide on the market.

Harmless to fowls. Don't have to grease or dust your fowls when you use it. Cans holding about $\mathbf{1}$ qt., 35c; 2 qts., 60e; gal., \$1.00; 5 gals., \$4.50.

\section{Archias' Animal Dip}

Disinfectant and livestock dip so assembled that it will aponify in water, forming a perfect mill white emulsion. One of the strongest and most concentrated products of the kind on the market.

Sheep-Scab, ticks, maggots, wounds, foot rot, worms. Poultry-Cholera, lice, mites, roup, gapes, disinfectant, caly legs.

\section{Scale Destroyer}

Directions-Dilute 1 to 20 for fall, winter and spring treatment, and 1 to 40 or 45 for summer treatment. Qt. can, 50c; $1 / 2$ gal. can, 85c; 1 gal. can, $\$ 1.50 ; 5$ gal. Wo.s0; 10 gal can, \$12.00.

(arge quantities of Insecticide, stat-

\section{Archias' Louse Powder \\ DISINTECTANT}

One of the most effective insecticides on the market, fasily applied and guaranteed to kill every species of parasite that preys on poultry and livestock. A trial will 25c; 5 1b. box, $\$ 1.15 ; 12$ lbs., $\$ 2.50$. If wanted by mail,

\section{Lambert's "Death to Lice"}

15 oz, box, 25c; $48 \mathrm{oz}$. box, 50c; 100 oz. package, $\$ 1.00$.

\section{Slug Shot}

Kills the currant worms, potato bug, cab-
bage worm, slugs on roses, caterpillars, aphis on roses, bugs on melons and bugs on asters, cut on fowls, sow bugs, lice plum, tobacco worms,

etc. 1 lb., 15c; 3 lbs., by mail, add 5e per lib. for postage.

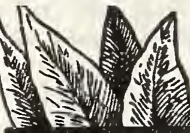

IILIS SulphoTobacco Soap

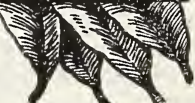

\section{INSECTS}

\section{Sulpho-Tobacco Soap}

3-oz, cake, 10c; 8-oz, cake, 20c; 1b., 35c.

Free with each order of a "Window Garden" booklet, by Eben Rexford, giving valuable information on cultivation of plants and of prepared solution. Mailed for 13c. An 8-oz. cake makes 4 gallons of the solution. Mailed for 1 ib., 35c; 5 lbs., $\$ 1.50$.

\section{Insect Powder Gun} comes it's moving day for bedbugs and other insects). Holds about 3 oz. powder. Price, 10c each; 3 for 5e; dozen, 75c. A 3-oz. cake makes $1 \frac{1}{2}$ gallons

Inscet Powder Guns (when it

Cattle-Lice, ticks, serew worms, sores, disinfectant, itch, mange, absorption.

Swine-Cholera, lice, mange, disinfectant, worms.

Dogs-Fleas, lice, mange.

General-Disinfectant, bed bugs, roaches, ants, wounds, burns, stings, ulcers, sort throat. One gallon Archias' Animal dip makes 50 to 100 gallons dipping solution. Directions on each can. Cans holding about 1 gal, \$1.25: 5 gals., $\$ 5.00 ; 10$ gals., $\$ 8.50$. Guaranteed or money re-

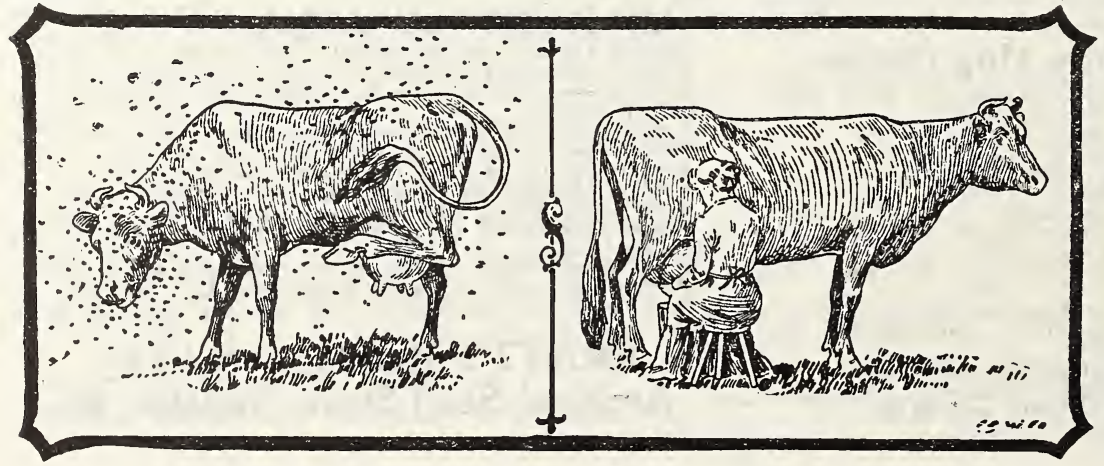

\section{Archias' \\ Fly Bouncer}

Excellent to protect stock from FLIES, GNATS and TICKS. Also Mosquitoes, Screw worms, Horn and Blow Flies, etc.

Archias' Fly Bouncer is highly recommended for galls, sores, burns, insect bites and stings and positively contains no poison, and will not injure the hair or blister if applied as dior blister if applied as dior money refunded. Put up or money refunded. Put up in cans holding about 1 qt., $45 c$; 2 q
$\$ 1.25 ; 5$ gals., $\$ 5.00$. 
A R C I A S' SEED STORE, SEDALIA, MISSOURI

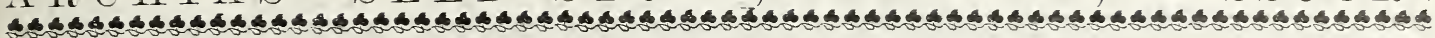
BEE KEEPERS' SUPPLIES

We make a specialty of the best Bee Supplies, and offer, at Factory Prices, the Iargest stock in the West. If interested write for catalogue of Bee Keepers' Supplies, mailed free. We make a specialty of three kinds of bee hives, viz.: The Archias' Dovetailed, Telescope and Root's simplicity Hive. These Hives take the Langstroth frame.

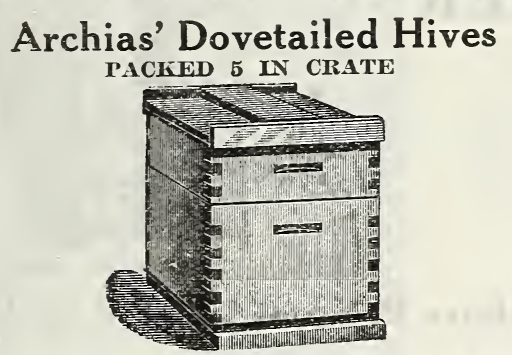

No. 1-E. Dovetailed (like cut), 8-frame, a $1 \frac{1 / 2-s t o r y}{1}$ hive for comb honey, with eight improved Hoffman frames; follower board, one super, with a follower and two wedges; 6 section holders with wood separators, nails for making hives and trimmings. 1 hive for $\$ 2.65 ; 5$ for $\$ 12.25 ; 10$ for $\$ 23.50$.

$1 \frac{1}{2}$-story, with sections and starters. No. 1. One hive, $\$ 2.95 ; 5$ for $\$ 13.75 ; 10$ for $\$ 26.50$.

No. 2 , a 2 -story hive for comb honey. 1 hive, $\$ \mathbf{5} .75 ; 5$ for \$18:25; 10 for $\$ 35.50$.

No. 5 Dovetailed: 8-frame, 2-story hive for extractor, and includes two bodies, with 16 improved Hoffman frames, nails and trimmings. Each, \$2.95; 5 for $\$ 13.70$; 10 for $\$ 26.00$.

\section{Archias' 10 Frame Dovetail Hives PACKED 5 IN CRATE}

One-story hive, no starters. No. $1 \mathrm{~A}, \mathbf{I}, \$ 2.00 ; \mathbf{5}, \$ 9.60$; $10, \$ 18.50$.

One and one-half story hives, no sections or starters. No. $1 \mathrm{E}, 1, \$ 2.85 ; 5, \$ 13.20$.

One and one-half story hives, with sections and starters. No. $1, \$ 3.20 ; 5, \$ 14.50 ; 10 . \$ 28.50$.

Two-story hive. with no sections or starters. No. 2 E, 1 , \$3.85; 5, \$17.75; 10, \$35.00.

Two-story hive, with sections and starters. No. 2, 1 , $\$ 4.25 ; 5, \$ 19.00$.

\section{Telescope Hives PACKED 3 IN CRATE}

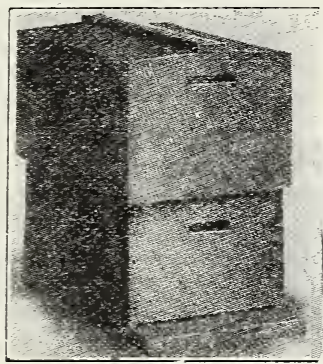

Style of Telescope Super

This cut represents our Telescope hive with two supers on and the hood slipped down over them. Broad chambers are just the same as in our dovetailed hive. But the supers have glass on one side, thus permitting the operator to see what is going on inside without disturbing the bees. Price of Telescope Hires, 15c each higher than for 8-frame Dovetailed Hives.

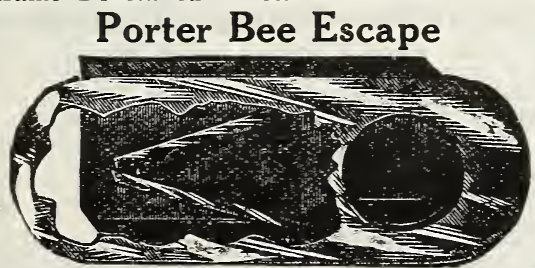

Porter Bee Escapes. Price, 20c each; per doz., \$2.00, postpaid.

Boards for Escape, 15c each.

\section{Honey Sections}

First quality white Northern Basswood; polished on both sides. Any style, but standard size only.

Unless you order otherwise we will send you sections $41 / 4 \times 41 / 4 \times 1 \frac{7}{8}$.

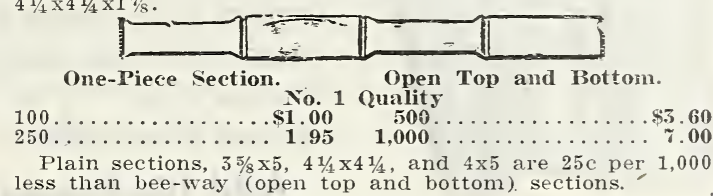

\section{Second Quality Sections}

$25 \mathrm{c}$ per 1,000 less than above.

Higginsville section press, each, 50c; by mail, 60c.

\section{Comb Foundation or Starter}

Extra thin for sections; 1 lb., 90c; 5 lbs., \$1.25.

Medium, for Brood Chambers; 1 1b., r0c; 5 lbs., $\$ 3.25$.

Special prices on larger quantities. Postage, $5 \mathrm{c}$ pound extra if sent by mail.

\section{Parker's Foundation Fasteners}

For putting comb foundation in sections. Anyone with a little practice can put in 500 starters an hour with them. Price, 30c each; by mail, 40c.

\section{Zinc Queen Excluders}

For 8 -frame hive, 27c each; 10 for $\$ 2.50$. For 10 -frame, 30c each; 10, \$2.75.

\section{Wood Bound Slatted Zinc Boards}

Eight frame, 40c each; 10, \$3.80; 10 -frame, 2c each extra.

\section{Bee Entrance Guards}

Large size, 18c each; 10 for $\$ 1.70$.

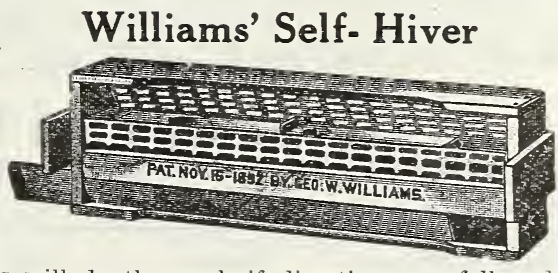

This will do the work if directions are followed. Full directions sent with each hive. Price, each, $\$ 1.00$.

\section{Alley's Drone and Queen Trap}

Can be used as a self-hiver with very little change. Price, 60c each; 15c extra by mail.

\section{Flowers for Any Occasion \\ ANY STYLE ANY SIZE ANY PRICE \\ Write or telephone your orders-we do the rest. We are members of the Florists' Telegraph Delivery As-
sociation, and deliver fresh flowers anywhere in the United States on one hour's notice. \\ Address Archias' Floral Co.}

ALL PRICES QUOTED IN THIS CATALOGUE

SUBJECT TO CHANGE WITHOUT NOTICE. WE MEET THE MARIET, QUALITY COXSIDERED. 


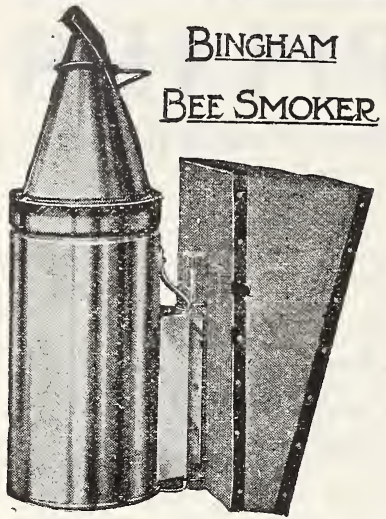

\section{BEE SUPPLIES-Continued 露}

\section{BEE SMOKERS}

Higginsville Smoker, best made..........\$0.85 Acme Smoker, 23/4 inches ................ .65

Bingham Little Wonder Smoker ......... .75

Bingham Conqueror Smoker ............ .90

Bingham Smoke Doctor................ 1.10

Bingham Smoke Engine ............... 1.35

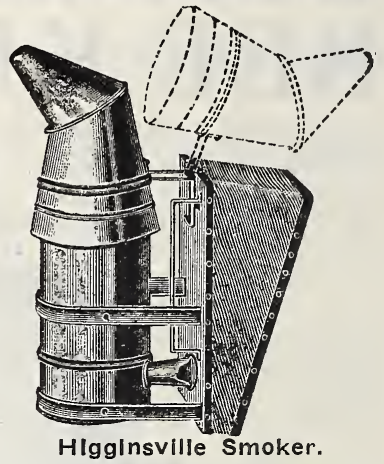

Add 10c Postage to Above Prices if Wanted by Mail

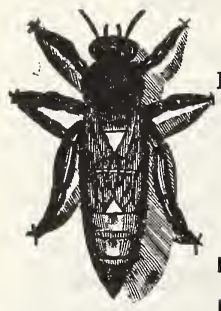

\section{Italian Bees}

Full colony bees in 8-frame telescope hives with tested queen, $\$ 7.50$.

Tested queen alone, $\$ 1.75 ; 3$ for $\$ 4.75$. Satisfaction guaranteed.

\section{Seeds of Honey Pro-} ducing Plants

Japanese Buckwheat, per bu., $\$ 3.50$; pk., $\$ 1.00$.

Sweet Clover Seed, 40c per Ib.; per pk., $\$ 4.50$.

Alfalfa Clover Seed, 30c per lb.; per pk., \$3.25.

Special prices on application.

\section{Bee Books}

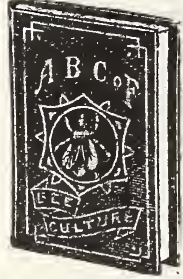

The Amateur Bee Keeper, an 80page book for beginners, $25 \mathrm{c}$ by mail, 28c.

Advanced Bee Culture, by W. Z. Hutchinson, $\$ 1.50$; by mail, $\$ 1.75$.

Doolittle on Queen Rearing, 60c; by mail, $70 \mathrm{c}$.

Bee Keepers' Guide, by Prof. A. J. Cook, $\$ 1.25$; by mail, $\$ 1.40$.

Langstroth on the Honey Bee- Revised by Dadant, $\$ 1.50$; by mall, $\$ 1.65$.

\section{A B C AND $X$ Y $Z$ OF BEE CULTURE}

The most complete book on Bee Culture ever written. Richly illustrated. Price, postpaid, $\$ 2.50$.

\section{Bee Veils}

Veil to cover the face and protect it from stings for the amateur bee-keeper is a necessity, and very convenient for the professional. The cotton tulle veil with silk face fits any hat.

Price, $85 \mathrm{c}$; by mail, $90 \mathrm{c}$.
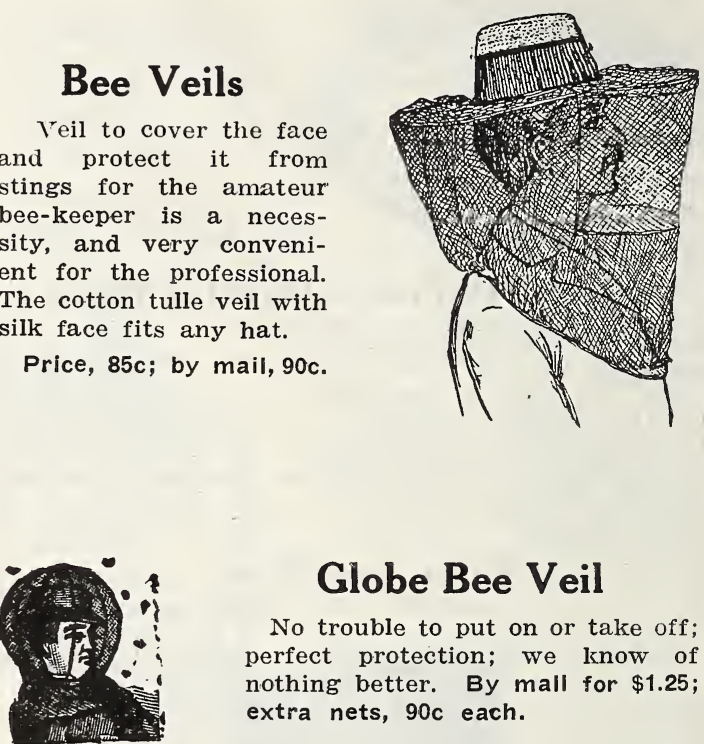

\section{Globe Bee Veil}

No trouble to put on or take off; perfect protection; we know of nothing better. By mall for $\$ 1.25$; extra nets, $90 \mathrm{c}$ each.

\section{Milk and Cream Coolers}

The following sizes of the Up-to-Date are gauged, as nearly as possible, to take care of the milk as fast as drawn from the various sized dairies with the average number of milkers. $B e$ sure to get one large enough, as best cooling results are obtained with low pressure milk in the receiver.

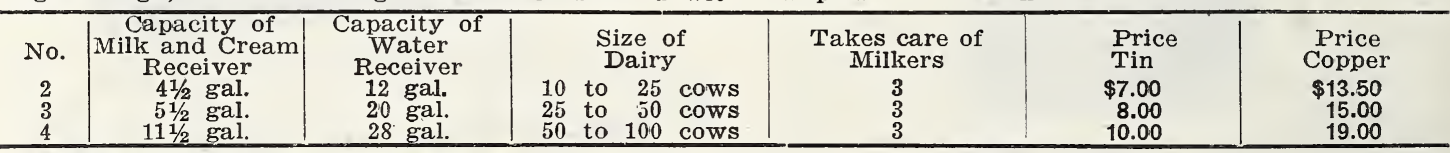

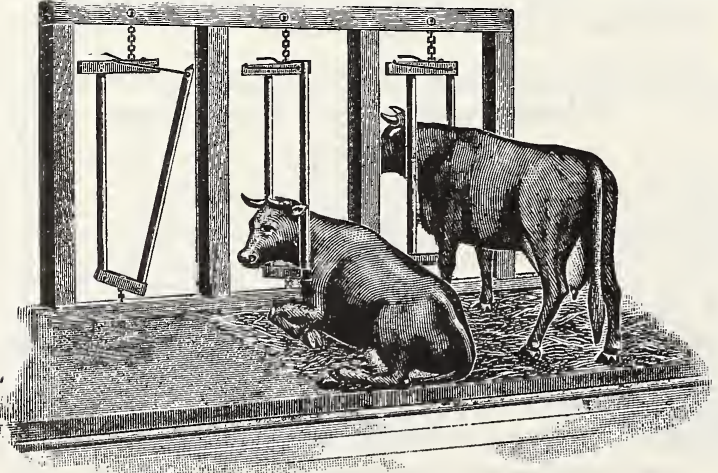

\section{DropLock, SteelSwing Stanchions}

\section{Comfortable-Strong-Inexpensive}

Made of a smooth spring steel tubing, not gas pipe, but a much stronger, stiffer and lighter material, guaranteed against bending or breaking. Not an ounce of malleable or cast iron is used.

The heads are rolled angle steel driven together to the tubing by strong rivets.

Are hung by chains at top and bottom, permitting the cows to move forward slightly when rising. Price, each, $\$ 2.35$; 10 for $\$ 22.50$.

Complete descriptive circular's upon application, illustrating sanitary and up-to-date stables.

We carry in stock Oil Meal, Cotton Seed Meal, Alfalfa Meal, Sugared Alfalfa for Dalry Feed-Car lots or less. Write for prices. State quantlty desired. 


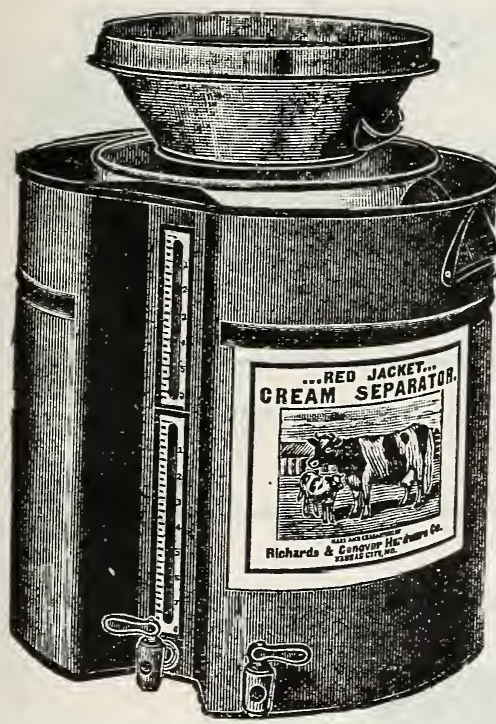

\section{Archias' Dairy Supply Dept.}

Complete Outfitters for the Dairyman, Milk Dealers, Milk and Cream for the Dairyman, Milk Dealer
Shippers and the Farm Dairy

\section{Archias' Red Jacket Cream Separator}

Best Cream Separator on the market. The inner can made of extra heavy no-rust tin, holds 12 gallons of milk, while the outer can or jacket is of the best galvanized iron, holds 12 gallons of water. Has two faucets. Separates all the cream in one hour and you have the fresh skimmed milk for your calves, pigs, etc. No crocks or pans to bother with. Every one guaranteed. Worth \$8.50; OUR PRICE ONLY \$6.00.

Special delivered price made on application.

\section{Archias' Best Separator Oil}

For Belt and Hand Separators

The very best separator, oil made, and fully warranted. Qt., 25c; gal., 85c; 5 gals., $\$ 4.00$.

\section{The Acme Bail Churn}

No. 0,5 gallons, weight 30 pounds......................... $\$ 4$

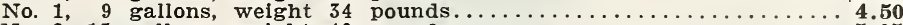

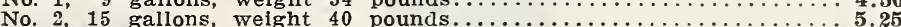

\section{Lever Butter Worker}

No. 0,20 in. wide, works 15 pounds................... $\$ 5.25$

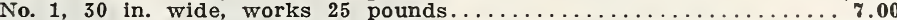

No. 2,40 in. wide, works 35 pounds........................ 8.00

\section{Diamond Crystal Dairy Butter Salt}

The best and only pure salt on the market for butter. $14 \mathrm{lb}$. bags, each, $25 \mathrm{c}$; 5 bags for $\$ 1.10$.

\section{Butter Prints}

$1 \mathrm{lb} .$, round, 15c each; $1 \mathrm{lb}$., square, 20c each; $1 \mathrm{lb}$., brick., shaped, 25c each.

Wood Butter Paddles-Each, 10c; 3 for 25c.

Elgin Butter Cartons-1 lb. size, $\$ 1.00$ per 100; $\$ 9.50$ per $\mathbf{1 , 0 0 0}$.

\section{Hansen's Danish Butter Color}

Guaranteed purely vegetable and in accordance with the Natinnal Pure Fond Law. 4-oz. bottle, 30c; 12-oz. bottle, 60c; 25-oz. bottle, \$1.20.

\section{Chr. Hansen's Rennet Tablets}

For cheese making. Box 50 tablets, postpaid, \$1.25.

Chr. Hansen's Junket Tablets

For household use. Vial of 10 tablets, postpaid, $10 \mathrm{c}$.

\section{The Facile}

Iron Irame Hand Babcock Tester 6 bottle tester...........\$9.50 8 bottle tester........... 10 bottle tester.......... 12.50 Prices include fuil set of glass. ware, comprising test bottles, pipette and acid measures; also test bottle brush and bottle of acid.

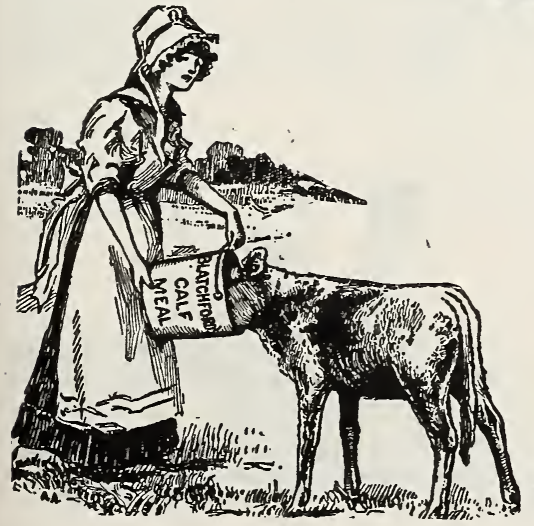
without milk.

\section{Square Parchment Butter Paper}

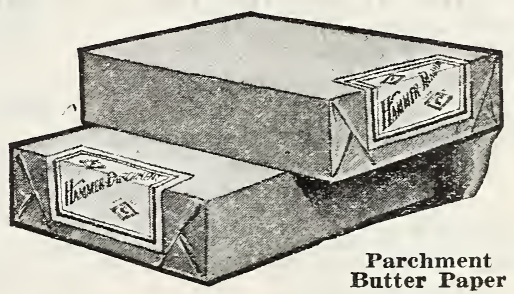

Archias' special heavy, per package, about 1,000 sheets, $\$ 1.00 ; 3$ packages, $\$ 2.75$.

Printing your card on paper, $\$ 1.50$ per 1,$000 ; \$ 2.75$ per 2,000 sheets extra.

The "Facile" Jr., Babcock Milk Tester

Complete with full set of glassware, consisting of test bottles, pipette and acid measures; also test bottle brush and bottle of acid, with full directions for use.

2 bottle machine, $\$ 5.00 ; 4$ bottle machine, \$5.50; combined milk and cream tester, $\$ 6.00$.

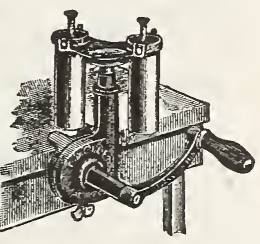

The perfect milk substitute-the best since 1800. Write today for free book, "How to Raise Calves."

\section{Blatchford's Calf Meal}

It is shown by government records and statistics that the slaughter of cattle in the United States between the years 1900 and 1910 increased 66 per cent; that the slaughter of calves during that period increased more than 500 per cent. Take advantage of the opportunity. Raise your calves

\section{Send For Pamphlet}

"How to Raise Calves Cheaply and Successfully Without Milk."

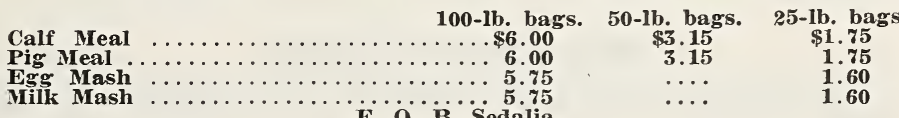


GR O W 'S U RE SEED S,', P L A N T A N D TRE E

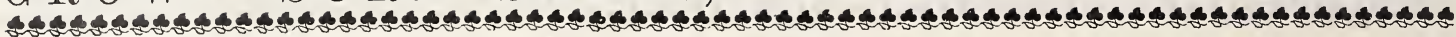

\section{BRUSHES}

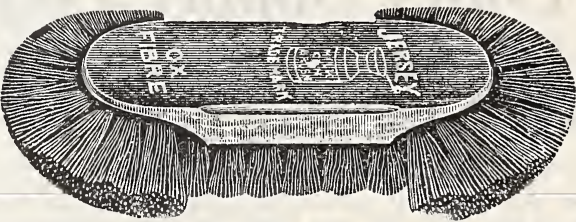

JERSEY CAN BRUSH

Guaranteed good, 9x5 inches ................. $\$ 0.45$ Gong-Pure ox fibre, solid black, $3 \frac{3}{4} \times 4 \frac{3}{4}$ inches. DUUCK $\ddot{\mathbf{C A N}} \ddot{\mathbf{B}} \ddot{\mathbf{R}} \dot{\mathrm{U}} \dot{\mathrm{SH}}$ Similar to Jersey, but smaller, $6 \times 21 / 2$ in. Each, $\$ 0.30$
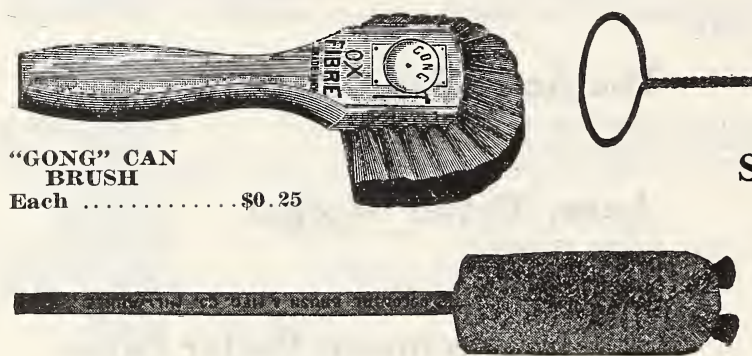

\section{Spiral Wire Milk Bottle Brush}

With India Bristle ${ }_{\text {With Gray }} \ldots \ldots \ldots \ldots \ldots \ldots \ldots \ldots \ldots \ldots \ldots \ldots \ldots \ldots$ Each,

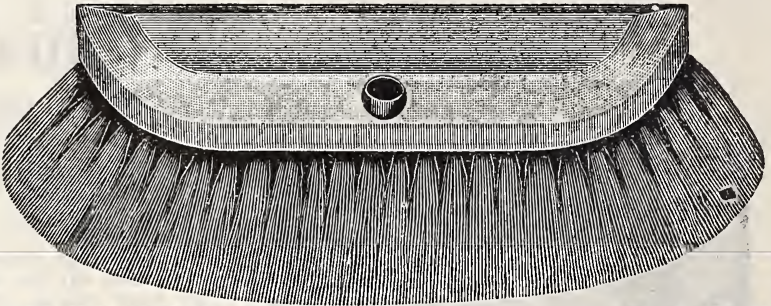

FLOOR BRUSH-Half round, rice root.

Each, \$0.60

povingtiriv

TEST BOTTLE AND SMALL SPOUT BRUSHES Each 10c, $15 \mathrm{c}$ and $25 \mathrm{c}$.

Separator Spout and Bowl Brush

Several styles and sizes, each 20c to 50c.

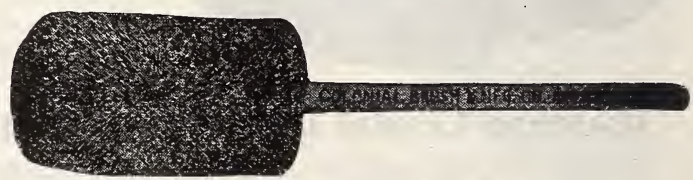

Wire Bound Bottle Brush

Extra quality, warranted...............Each, \$0.45

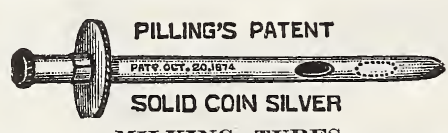

MILKING TUBES

2 in., solid coin silver, $40 \mathrm{c}$; plated. .\$0.30 3 in., solid coin silver, $50 \mathrm{c}$; plated... .35

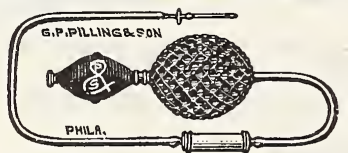

THE PILLING MILK FEVER OUTFIT For Air Treatment.

Sent prepaid, with full instruction on receipt of $\$ 3.00$. "Easy to use."

\section{Pilling Cattle Instruments \\ Case No. 1, $\$ 5.50$}

This case polished oak, containing the following instruments:

Nos. 1, 2, 3, 5, 6, constitute Pilling

Milk Fever Outfit..........\$3.00

No. 4, Pilling Animal Soap....... .25

No. 7, Linen Bandage, 10 yds... .25

No. 8, Pilling Milk Tube........ .50

No. 9, Medium Size Lead Probe.. .25

No. 10, Pilling Teat Opening....... .75

No. 11, Pilling Teat Bistoury..... 1.50

Total value $\ldots \ldots \ldots \ldots \ldots \ldots \ldots \$ 6.50$

With full directions, our price, only $\$ 5.50$.
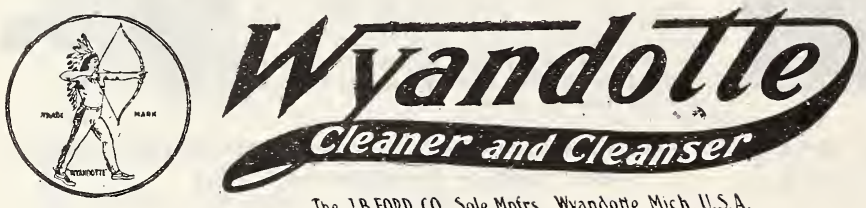

The J.B.FORD CO.. Sole Mnfrs. Wyandorte Mich U.S.A.

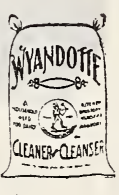

Wyandotte Cleaner

A cleaning compound in powder form for scrubbing floors, tables, vats and churns, ete., for washing milk cans and bottles, and cleaning windows; in fact, for any and every purpose. Makes everything clean, sweet and pure. 5-1b. bag, only 45c.

\section{Archias' Special Milk Bottles}

Iade of extra heavy glass, absolutely accurate in measurement, easily cleaned and the best made.

$1 / 2$ pint, 50c dozen; 6 dozen, $\$ 2.75 ; 12$ dozen, $\$ 5.25 ; 1$ pint, $65 \mathrm{c}$ dozen; 6 dozen for $\$ 3.50 ; 12$ dozen, $\$ 6.50 ; 1$ quart, 75c dozen; 6 dozen, $\$ 4.25 ; 12$ dozen, $\$ 8.00$.

$1 / 2$ gal. milk bottles, $\$ 2.00$ per dozen.

Archias' Standard Milk Bottle Caps. See inside back cover.

\section{Wire Delivery Baskets}

Like above cut, for carryíng milk bottles. Made for six 1-quart bottles or four quart and two pint bottles. Each, 85c; 8 bottle carriers, 4 qts. and 2 pts., 90c each.

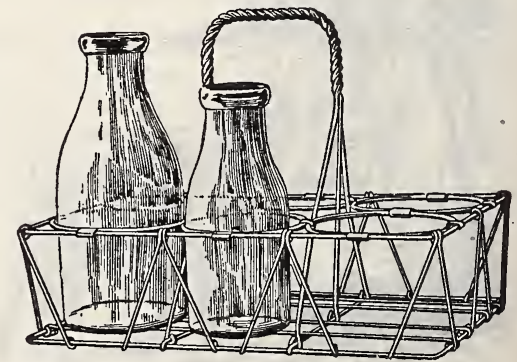


Vegetable Seeds

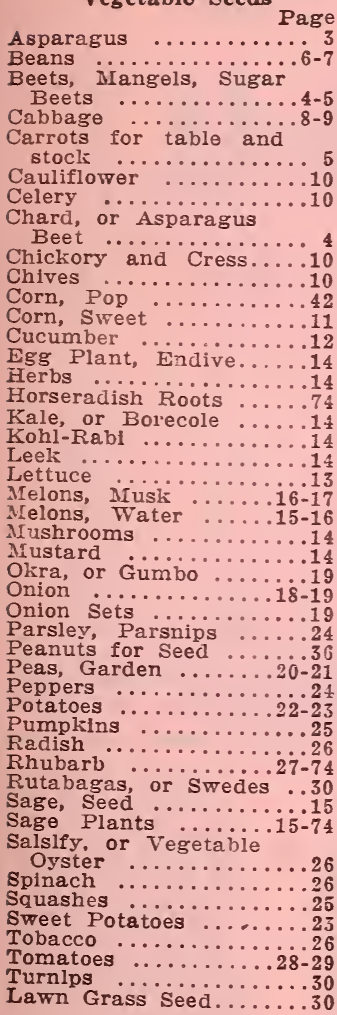

\section{Farm Seeds}

Alfalfa

Broom Corn $\ldots \ldots \ldots \ldots \ldots, 33$
Barley $\ldots \ldots \ldots \ldots, 33$

Bermuda Grass $\ldots \ldots \ldots . . . . .31$

Buckwheat $\ldots \ldots \ldots \ldots \ldots .33$

Cane Seed $\ldots \ldots \ldots \ldots \ldots \ldots .31$

Corn, Fleld . 38-39-40-41-42

Cotton ..............

Feterita $. . . \ldots \ldots \ldots \ldots . .34$

Field Peas $\ldots \ldots \ldots \ldots \ldots \ldots \ldots$

Grasses .................

Jerusalem Corn ............

Mafir Corn $\ldots \ldots \ldots \ldots \ldots \ldots, 34$

Milo Maize ..............

Oats ..................

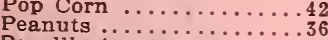

Penclllaria

Rape, Dwarf Essex..........

Rye ........................

\begin{tabular}{|c|c|}
\hline Page & Petunia \\
\hline $\begin{array}{l}\text { Shallu } \\
\text { Speltz }\end{array}$ & $\begin{array}{l}\text { Petunia } \\
\text { Poppies }\end{array}$ \\
\hline Beans & Portulaca, Pyrethium \\
\hline Sunflower $\ldots$. & Salvia \\
\hline Sudan Grass & Schizanthus \\
\hline Teosinte $\ldots \ldots \ldots \ldots \ldots 35$ & $\begin{array}{l}\text { Sinilax, Stocks } \\
\text { Snapdragon }\end{array}$ \\
\hline $\begin{array}{l}\text { Vicla Vlllosa or Hairy } \\
\text { Vetch } \ldots \ldots \ldots \ldots \ldots \ldots . .35\end{array}$ & $\begin{array}{l}\text { Snapdragon } \\
\text { Sunflowers . }\end{array}$ \\
\hline & $\begin{array}{l}\text { Sweet Peas } \\
\text { Sweet Willi }\end{array}$ \\
\hline Flower Seeds & $\begin{array}{l}\text { Sweet Will1 } \\
\text { Tuberoses }\end{array}$ \\
\hline bronia . & $\begin{array}{l}\text { Verbena Seed, } 54 ; \\
\text { Vinca, Violet, Seed }\end{array}$ \\
\hline glumi Cirhose .... & Vinca, Plants \\
\hline yssum $\ldots$ & Wild Flower Garde \\
\hline atlrrhinum & Zinnia .... \\
\hline
\end{tabular}

\section{Plants, Bulbs and}

Aquileg

Balloon Vine

Balsam ..............44

Balsam Applo and Pear.46

Bellls Daisies ........48

Butterfly Flower

Calendula

Calliopsis.$\cdots \cdots \cdots \ldots \ldots \ldots 45$

Campanula, Canterbury

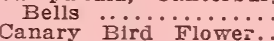

Candytuft

Cannas

Carnation Seed

Castor Beans

Celosia, Cockscomb ......48

Centaurea (Cornflower)..44

Cineryanthemum .......48

Cobea Scandens ..........4

Cobea Scandens .......4

Columbine $\ldots \ldots \ldots \ldots \ldots 44$

Cucumber, Wild

Cypress Vine

Dahlia Da...................

Dlanthus, Pink ........

Digitalis $\ldots \ldots \ldots \ldots \ldots 48$

Dollchos, or Hyaclnth

Bean 0 itzia

Eschscholtzia $\ldots \ldots \ldots \ldots \ldots 48$
Euphorbia $\ldots \ldots \ldots \ldots$

Everlastlng Fioyers .......49

Forget-me-not ..........48

Galllardia ...............

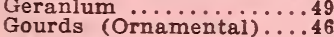

Heliotrope ............49

Hibiscus $\ldots \ldots \ldots \ldots \ldots \ldots, \ldots 99$

Hollyhocks

Hop, Japanese ..........46

Ice, Plant $\ldots \ldots \ldots \ldots \ldots 49$

Job's Tears ...........49

Kochla Tricophylla

Kudza Vine $\cdots \cdots \cdots \cdots, 46.40$

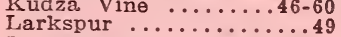

Lathyrus, Hardy Sweet

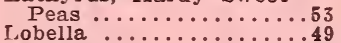

Lobella Marigolds $\ldots \ldots \ldots \ldots \ldots .49_{49}$

Marvel of Peru ...........49

Mignonette, Nrimulus ....49

Moonflower $\ldots \ldots \ldots \ldots \ldots 47$

Morning Glories $\ldots . . . .47$

irusk Plant ............48

Nasturtimus $\ldots \ldots \ldots \ldots \ldots$

Nigella $\ldots \ldots \ldots \ldots \ldots \ldots 48$

\section{N}

Achillea Alternanthera

Althea.

Ampelopsis

Apios Tuberosa

Asperagus Fern

Bedding Plants

Begonias

Bleeding Hearts

Caladiums

Callas

Calycanthus

Campanula

Cannas ....

Carnations ……

Cinnamon Vine

Cinnamon Vine

Clematls, seven vest

varieties

Dahlias

Daisies

Deutzia ........

Dutch Bulbs

Ferns

Flowering shrubs

Flowering Shrubs ...

Fruit Trees and Berry

Plants .......70-71-72-73

Geraniums ........... 59

Gladiolus .............6. 69

Golden Glow .........6. 65

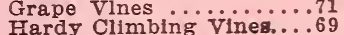

Hardy Perennials .... 66-67

Hedge Plants .........67

Heliotrope...

Hibiscus

Hollyhock.

Hydrangeas

[mpatlence Sultana

[ris

Lllac

Lantana.

Maderia Vine

Mallow Marvels

Moonflower Plants

Ornamental Trees

Peonles

Phlox, Härdy

Privet Hège

best the sweetest and
Honeysuckie

Lemon and Örange
Salvia $\ldots . . \ldots \ldots \ldots$ Page

Sanseveria Zelancia ...61

Snowballs-Spirea

Swainsonia Alba.

Syringo (Mock Orange)..61

Tritoma Pfitzeril ......61

Vegetable Plants and

Roots

Wandering Jew

Weigelia

Wistaria

Yucca

Poultry Supplies

84-85-86-87-88-89-90-91-92

Alfalfa Meal .........90

Bone for Poultry ......99

Charcoal for Poultry and

Hor 84

Chick Feed and Hèn.

Feed

Chick Märker

Conkey's Remedies

Coops

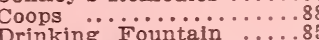

Drinking Fountain $\ldots$...85

Grit, Mica and Crysco..84

Insecticides and Fly

Killers

Incubators aind Brooders

• ${ }^{\circ}$.........86-87

Leg Bands for Poultry..8

Nest Eggs $\ldots \ldots \ldots \ldots \ldots .8 . . . .87$

Pigeon Supplles, Foods,

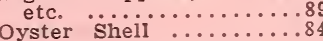

Miscellaneous

Bee sppplies and

Bees ........

$93-94$

Baskets

Birds, Bird Seed and ${ }^{\cdots}$

Supplies ........8

Corn Shellers ....

Designs .........76-77

Designs

Discounts on Seed and

Supplies ..............

Dog and Cat Foods and

Supplles

Fanning Mills .........80

Farmogerm, a new Fer-

tillzer ..........

Foods ................

Florists' Supplies .....74-75

Gold Fish and Fish

Supplies .........82-83

Hot-Bed Sash

Hot-Bed Sash

Nitrate of Soda .......37

Plant Stands and Brack-

ets

Raffia and Reeds for

Baskets .............75

ers ......... fö Or

chard and Garden ....78

Thermometers ......75-88

Tools for Garden and

Farm .........78-79-80

valuable Täbles ..42-50-74

RAT CORN-The great rat extermlnator. See page 42.

OUR PRICES on everything in this catalogue are so very much lower than the same quallty of goods can be bought elsewhere that after you pay all transportation charges, even to very distant points, we can still SAVE YOU MONEY.

LOOK BEFORE SEALING YOUR ORDER Go over the index carefully, as otherwise you mlght overlook Bomethlng. Don't forget to order Archias' Everbearing Strawberrles and St. Regis Everbearing Raspberries; Archlas' Missour Glant Tree Tomato; Archias' Dellclous Apple; Archlas' Missourl Pride Peach and a good assortment of bulbs, plants 
Now that we have a domestic Parcel Post System (although the zone divisions make it slightly cumbersome), a better regulated.

Bulk limit (measurement around package both ways) in all zones 72 inches. Liquids and goods packed in giass should be sent by express

\section{PARCEL POST RATES FROM SEDALIA, MO.}

\begin{tabular}{|c|c|c|c|c|c|c|c|c|c|}
\hline $\begin{array}{l}\text { ס2 } \\
\text { 年 } \\
\text { 号 } \\
0 \\
\Omega_{1}\end{array}$ & 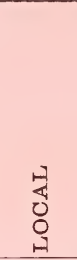 & 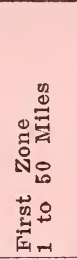 & 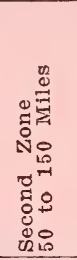 & 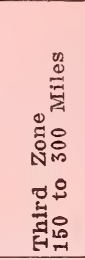 & 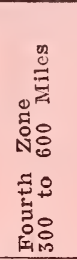 & 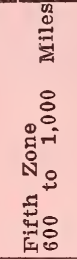 & 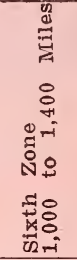 & 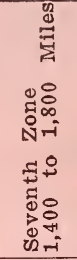 & 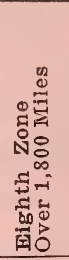 \\
\hline $\begin{array}{r}1 \\
2 \\
3 \\
4 \\
5 \\
6 \\
7 \\
8 \\
9 \\
10 \\
11 \\
12 \\
13 \\
14 \\
15 \\
16 \\
17 \\
18 \\
19 \\
20 \\
91\end{array}$ & $\begin{array}{r}\$ 0.05 \\
.06 \\
.06 \\
.07 \\
.07 \\
.08 \\
.08 \\
.09 \\
.09 \\
.10 \\
.10 \\
.11 \\
.11 \\
.12 \\
.12 \\
.13 \\
.13 \\
.14 \\
.14 \\
.15\end{array}$ & $\begin{array}{r}\$ 0.05 \\
.06 \\
.07 \\
.08 \\
.09 \\
.10 \\
.11 \\
.12 \\
.13 \\
.14 \\
.15 \\
.16 \\
.17 \\
.18 \\
.19 \\
.20 \\
.21 \\
.22 \\
.23 \\
.24 \\
.25\end{array}$ & $\begin{array}{r}\$ 0.05 \\
.06 \\
.07 \\
.08 \\
.09 \\
.10 \\
.11 \\
.12 \\
.13 \\
.14 \\
.15 \\
.16 \\
.17 \\
.18 \\
.19 \\
.20 \\
.21 \\
.22 \\
.23 \\
.24\end{array}$ & $\begin{array}{r}\$ 0.06 \\
.08 \\
.10 \\
.12 \\
.14 \\
.16 \\
.18 \\
.20 \\
.22 \\
.24 \\
.26 \\
.28 \\
.30 \\
.32 \\
.34 \\
.36 \\
.38 \\
.40 \\
.42 \\
.44 \\
\end{array}$ & $\begin{array}{r}\$ 0.07 \\
.11 \\
.15 \\
.19 \\
.23 \\
.27 \\
.31 \\
.35 \\
.39 \\
.43 \\
.47 \\
.51 \\
.55 \\
.59 \\
.63 \\
.67 \\
.71 \\
.75 \\
.79 \\
.83 \\
\end{array}$ & $\begin{array}{r}\$ 0.08 \\
.14 \\
.20 \\
.26 \\
.32 \\
.38 \\
.44 \\
.50 \\
.56 \\
.62 \\
.68 \\
.74 \\
.80 \\
.86 \\
.92 \\
.98 \\
1.04 \\
1.10 \\
1.16 \\
1.22 \\
\end{array}$ & $\begin{array}{r}\$ 0.09 \\
.17 \\
.24 \\
.33 \\
.41 \\
.49 \\
.57 \\
.65 \\
.73 \\
.81 \\
.89 \\
.97 \\
1.05 \\
1.13 \\
1.21 \\
1.29 \\
1.37 \\
1.45 \\
1.53 \\
1.61 \\
\end{array}$ & $\begin{array}{r}\$ 0.11 \\
.21 \\
.31 \\
.41 \\
.51 \\
.61 \\
.71 \\
.81 \\
.91 \\
1.01 \\
1.11 \\
1.21 \\
1.31 \\
1.41 \\
1.51 \\
1.61 \\
1.71 \\
1.81 \\
1.91 \\
2.01 \\
\end{array}$ & $\begin{array}{r}\$ 0.12 \\
.24 \\
.36 \\
.48 \\
.60 \\
.72 \\
.84 \\
.96 \\
1.08 \\
1.20 \\
1.32 \\
1.44 \\
1.56 \\
1.68 \\
1.80 \\
1.92 \\
2.04 \\
2.16 \\
2.28 \\
2.40 \\
\end{array}$ \\
\hline
\end{tabular}

\begin{tabular}{l|l|l|l}
22 & .15 & .25 & .26 \\
23 & .16 & .27 & .2 \\
24 & .16 & .28 & .2 \\
25 & .17 & .29 & .2
\end{tabular}

Above rates apply from Sedalia, as shown in table. The first zone extends about fifty miles out from Sedalis, the second zone gbout 150 miles, the third zone about 300 miles, the fourth about 600 miles and the fifth about 1,000 miles.

Please ask your postmaster what zone you are in, make note of it and use this table.

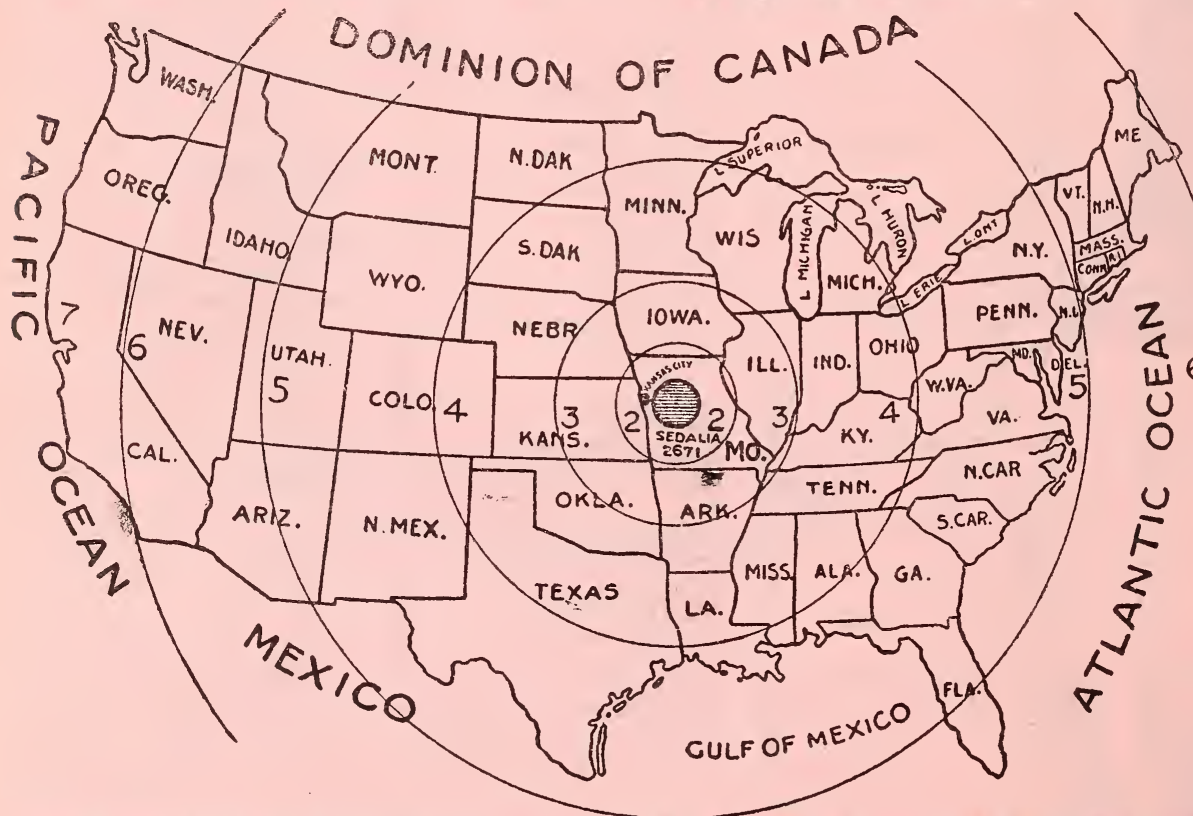

Seeds, plants and bulbs can be malled, the rate of postage being 1c for each two ouncea on packages weighing up to 8 ounces. Anything over 8 ounces takes the pound rate; that is, package weighing to 16 ounces talres to 16 ounces takes the rate for one pound, and one weighing 17 to 32 ounces takes the rate for two pounds
and so on. Therefore, when you want one pound of seed remit posta ge for two pounds, as packing will increase will welght. There three three cents difference.

The weight limit of a single package to zones 1 and 2 is 50 pounds: to a 110 thers 20 pounds.

We pay postage on all garden seeds in packets, ounces, one-fourth and one-hale pou nd s and pounds. Add 5e per pound postage on grass seeds, seed grain and $5 \mathrm{c}$ per pint and $8 \mathrm{c}$ per quart for corn, peas and beans when wanted by mail.

\section{OUR LIBERAL CASH DISGOUNT}

Free Seeds or Discounts for Large Orders BULK SEED DISCOUNT

On orders amounting to $\$ 5.00$, deduct 10 per cent.

On orders amounting to $\$ 10.00,12$ per cent.

On orders amounting to $\$ 15.00,15$ per cent.

Providing you use the prices given in this book and do not Include any Field Seeds, Grass Seeds, Potatoes, Onion Sets, Poultry Supplies, etc., on which we only give lowest net prices at time catalogue is issued.
PACKET AND OUNCE SEED DISCOUNT

For 25c we send $30 \mathrm{c}$ worth of seeds, packet or ounce.

For $50 \mathrm{c}$ we send $65 \mathrm{c}$ worth of seeds, packet or ounce.

(1.30 worth of seeds, packet or ounce.

for our packet and ounce discount on larger quantity than packets or ounces of any kind can be included.

FREE SEEDS-In addition to the above discounts we make a rule of throwing in extra packets where liberal orders are sent in. Try us once and see if we don't treat you right. 


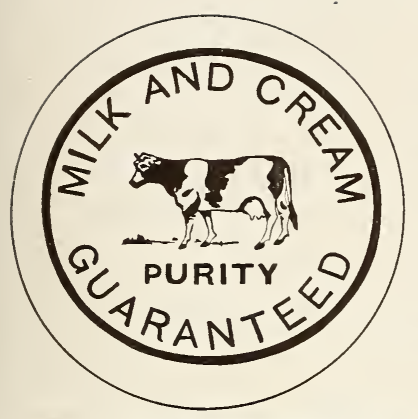

\section{Archias' Sanitary Milk Bottle Caps}

Archias, Milk Bottle Caps are made of A No. 1 paper stock, perfect and clean cut, thoroughly accurate and uniformly paraffined. Packed carefully. Full quantity and quality guaranteed. Our 60e; 5,000 for \$2.25. Ask for prices on larger quantities..

Caps with Lip or Tongue-Most con-
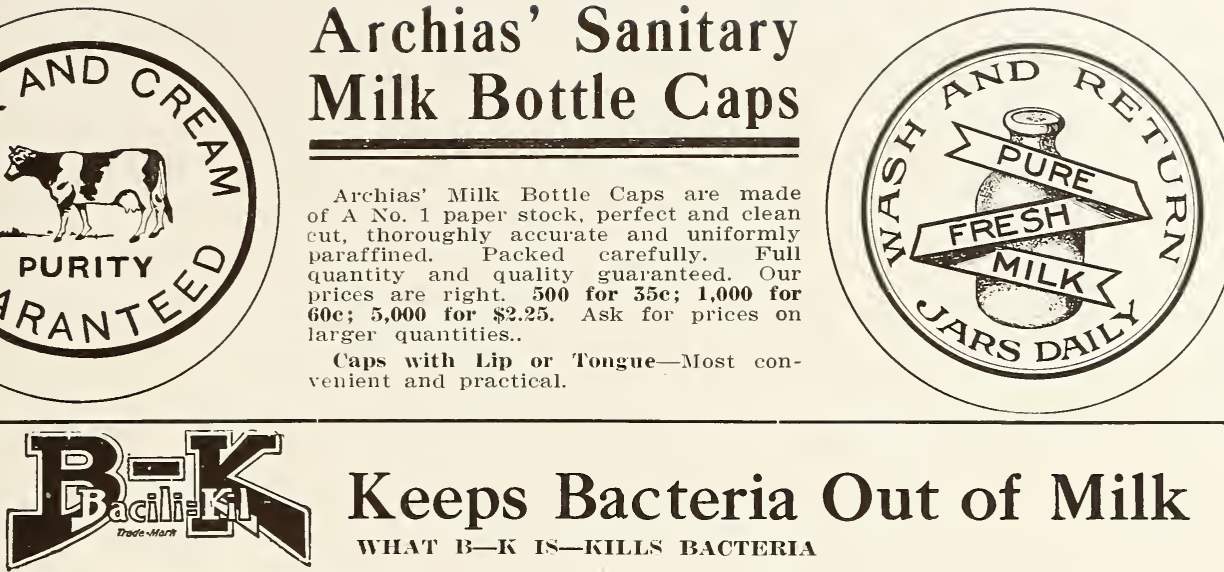

Keeps Bacteria Out of Milk

WHA'T IB-IE IS-KILLS BACTERIA

$\mathrm{B}-\mathrm{K}$ is a dairy sterilizer and purifier.

Destroys Foul Odors-B-K destroys the odors and kills the bacteria which causes them-leaves no odor of itself vimple and Practical.

B-I is Not an Adulterant or Preservative-It is not put into milk or dairy products, but is used as a rinse to sterilize the containers. Its use, according to directions, violates no law.

More effective than steam as ordinarily used, it is cheap, clean. harmless and does not taint. $\mathrm{P}-\mathrm{K}$ is sold on a posi tive guarantee to please or money refunded. Write for circular giving full information, mailed free.

Price of B-K. 1 qt. bottle, $\$ 1.00 ; 1$ gal., \$2.50; 5 gal., \$11.00. (The cost of a gallon of delution ready for use is less than one cent).

Freight Rates at this Date from Sedalia, Missouri, to Station Named

Per 100 lbs., on Third and Fourth Class Freight in Barrels, Boxes or Sacks, Less Than Car Lots.

Potatoes, Garden Seeds, Clover and Grass Seeds go as Third Class: Grain and Corn, Fertilizers, Shells and most Poultry Supplies and Bee Hives go as Fourth Class. You can approximate by noting rate to some point near you.

AITIMA

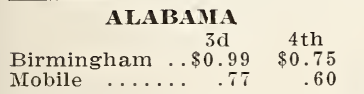

ARIZONA

$\begin{array}{llr}\text { Douglas } & \ldots \ldots \$ 2.05 & \$ 1.71 \\ \text { Phoenix } & \ldots \ldots & 2.05\end{array}$

ARIKANSAS

Bald Knob....\$0.74

$\begin{array}{ll}\text { Fayetteville } . . & .79 \\ \text { St. Smith ... } & .65\end{array}$

Helena

Little Rock

Pine Bluff

Texarkana

Wynne...

CALIFORNIA

Los Angeles ...\$2.38

San Francisco. 2.38

\section{COLORADO}

Colorado Spgs.\$0.98

Denver ........ .98

Glenwood Spgs. 1.95

Pueblo ...... 98

\section{ILLINOIS}

Cairo ......\$0.45 \$0.32

$\begin{array}{lr}\text { Chicago } \cdots & .45 \\ \text { Metropolis } \cdots & .50\end{array}$

Peoria ...

Rockford ... . .45

\section{INDIANA}

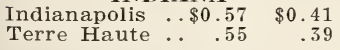

\section{IOWA}

Burlington $\$ 0.40$.

Burlington $\$ 0.40$.

Clarinda

Council Bl'ffs

Davenport

Keokuk

Ottumwa

Shenandoah

$\$ 0.291 / 2$

$.291 / 2$

$.291 /$

$.291 / 2$

$.291 / 2$

$.291 / 2$

\section{KENTUCKY}

KENTUCKY
Louisville . . .

$\begin{array}{ll}\text { Paris } \ldots \ldots \ldots & .59 \\ \text { Paducah } & .79\end{array}$

$\$ 0.41$

\section{IKANSAS}

Arkansas City.. $\$ 0.75 \quad \$ 0.63$ Coffeyville El Dorado

Galena

Iola

Liberal

Olathe

Oswego

Pittsburg

Wichita

\section{LOUISIANA} Alexandria ....\$0.95
Baton Rouge . $\quad .77$

Shreveport

MINNESOTA
St. Paul $\ldots \ldots \$ 0.48$

MISSISSIPPI

Aberdeen ......\$0.89

Greenville

Holly Springs

Vicksburg...

MISSOURI

Appl't'n City. $\$ 0.21$

Aurora ..... . . 44

Bagnell

Boonville

Bunceton

Calhoun

California

Cameron

Carthage

Clifton Cit

Cole Camp

Clinton

Concordia

Cuba

Dresden

Eldon

Eldo'do Spgs.

ayette ....

Green Ridge

Harrisonville

Hannibal

Holden

Jefferson $\dot{C}^{\prime} \dot{y}$

.15

$441 / 2$

35

$\begin{array}{ll}471 / 2 & .351 / \\ 10^{1 / 2} & .09\end{array}$
DISTANCE NO DRAWBACK-No matter how far away you may live, we can still save you money on your purcases. Bear in mind that your local dealer is obliged to pay the same rate of freight that you pay on your goods, and this cost of freight must be added to the cost of his goods when he figures his selling price.

\begin{tabular}{|c|c|c|c|c|}
\hline \multicolumn{3}{|c|}{ MISSOURI-CON. } & \multicolumn{2}{|l|}{ OIEI,AHOMA } \\
\hline & $3 d$ & 4 th & $3 \mathrm{~d}$ & 4 th \\
\hline Joplin .... & 0.35 & $\$ 0.25$ & $\ldots \$ 0.84$ & $\$ 0.7$ \\
\hline Kansas City & .24 & .18 & Adair & \\
\hline Knobnoster & .13 & .11 & $\ldots \ldots$ & \\
\hline amonte ... & .12 & .10 & Atoka $\ldots \ldots$. & \\
\hline Cebanon ... & .64 & .50 & Bartlesville ... & \\
\hline Lexington . & .18 & .14 & Chandler ..... & \\
\hline Lincoln .... & .15 & .13 & Enid ....... & \\
\hline Lowry City & .40 & .32 & El Reno ...... & \\
\hline Marshall .. & .23 & .18 & Guthrie $\ldots \ldots$ & \\
\hline Ionette & .57 & .41 & Guymon & \\
\hline ontrose .. & .20 & .16 & McAlester ..... & \\
\hline oberly & .23 & .17 & Miami .... & \\
\hline Mora & .12 & .10 & Oklahoma C'y. & \\
\hline evada & .25 & .18 & Poteau ...... & \\
\hline New Franklir & .17 & .14 & Sallisaw $\ldots \ldots$ & \\
\hline tterville & .12 & .10 & Shawnee ...... & \\
\hline Pleasant Gr'r & .12 & .10 & Tulsa & \\
\hline Pleasant Hil & .18 & .1 & Wagoner & \\
\hline plar Bluff & .68 & .5 & Woodward ... & \\
\hline
\end{tabular}

\section{SOUTH DAKOTA}

Rea.. $.46 \quad .36$

Rich Hill

Svracuse

Smithton

St. Joseph

Strasburg

Sweet Spgs

Tipton

Versailles.

Warrensburg

Warsaw

Windsor

Butte .....\$

Helen

NEBRASKA

Hastings $\ldots \ldots . \$ 0.66 \quad \$ 0.51$
Lincoln $\ldots \ldots$

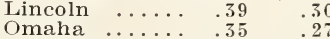

\section{NEW MEXICO}

Albuquerque. $\$ 1.70 \quad \$ 1.47$

Alamogordo ... 1.47 1.34

Dawson ........ 1.33 1.10

Roswen

Santa Fe

Santa Rosa

1.37
1.59

Sunnyside

$\begin{array}{ll}1.46 & 1.3 \\ 1.37 & 1.34\end{array}$

Tucumcari $\ldots .1 .31 \quad 1.11$

\section{NORTH DAKOTA}

Bismarck ...\$1.10 \$0.81 OHIO

Columbus $\ldots \ldots \$ 0.62 \quad \$ 0.45$
TEXAS

\begin{tabular}{|c|c|c|}
\hline & 11 & \\
\hline bilene & $\ldots \ldots \$$ & \\
\hline marillo. & $\ldots \ldots .96$ & \\
\hline stin & $\ldots 1.04$ & \\
\hline llas & $\ldots \quad .96$ & \\
\hline enison & .96 & \\
\hline Paso & 1.22 & \\
\hline t. Worth & .96 & \\
\hline ereford. & ... 1.07 & \\
\hline uston & $\ldots 1.04$ & \\
\hline aris & .96 & \\
\hline Anton & nio... 1.04 & \\
\hline ermań & $\ldots$ & \\
\hline & $\cdots$ & \\
\hline chita & ls. & \\
\hline
\end{tabular}

TENNESSEE

Chattanooga ..\$1.06 \$0.8

Jackson … . . $81 \quad .62$

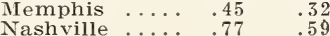

\section{СТАН}

Ogden ......\$1.63 \$1.34 Salt Lake City $1.63 \quad 1.34$

\section{WISCONSIN}

$\begin{array}{rr}\text { Milwaukee ... } \$ 0.45 & \$ 0.32 \\ \text { Madison ..... } & .45\end{array}$

WYOMING
Cheyenne

Cheyenne
Sioux Falls..\$0.47 \$0.33 


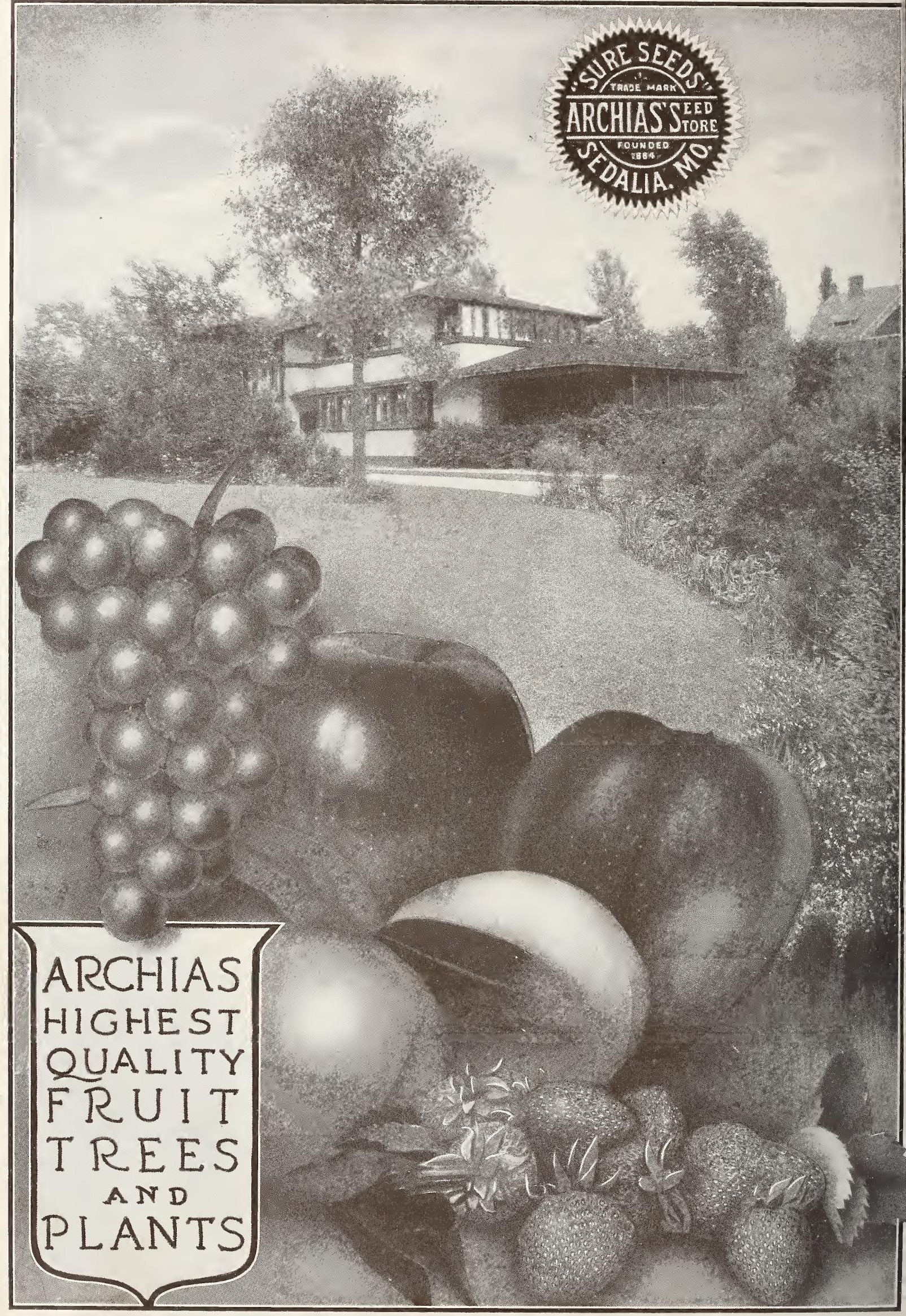

